\title{
EDUCAÇ̃̃O CONTEMPORÂNEA
}

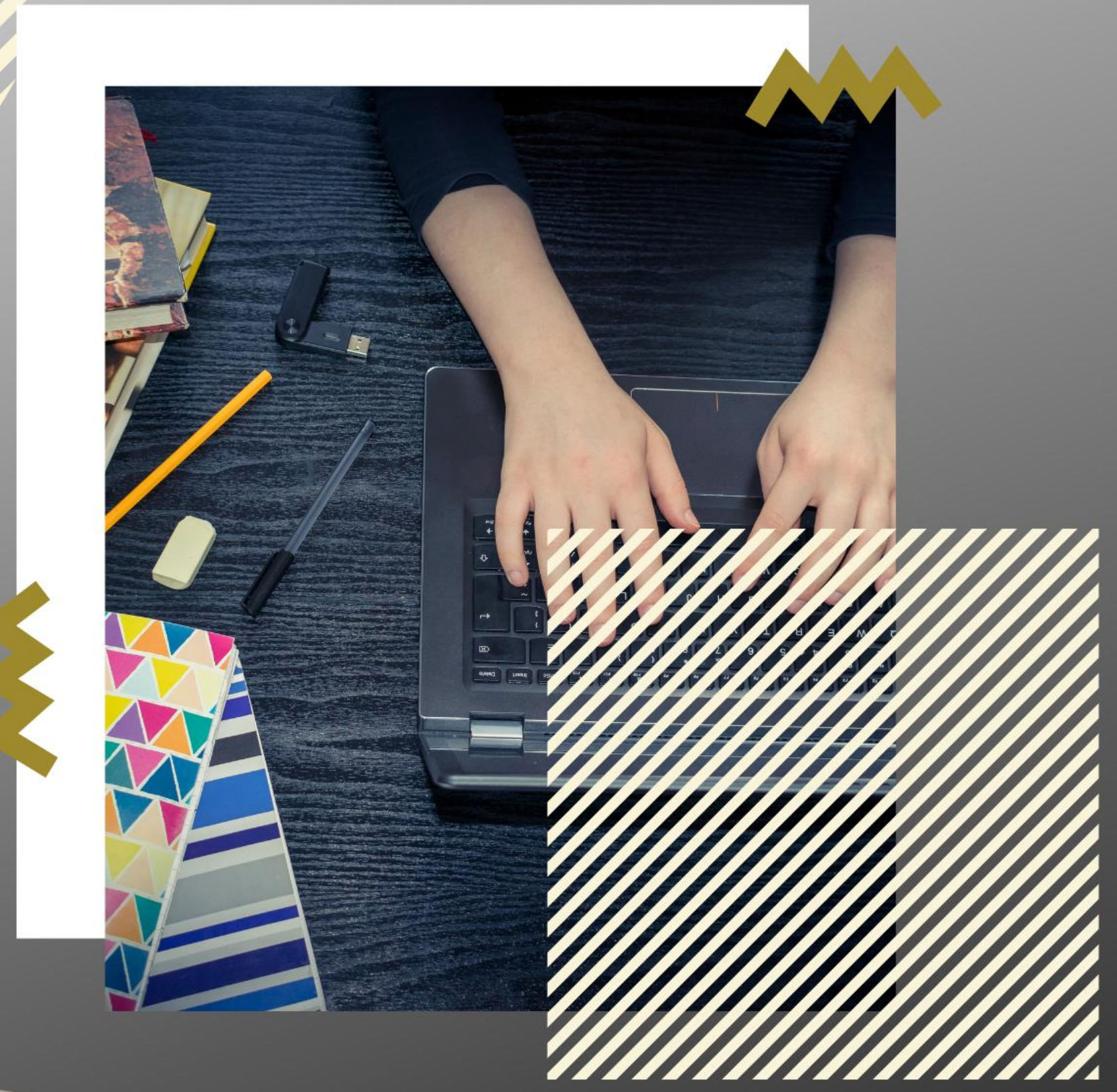

Organizadora

Bruna Guzman de Jesus

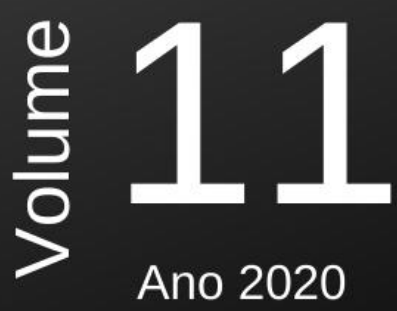


Brunz Guzman de Jesus

(Organizadora)

Educação Contemporânea - Volume 11

1a Edição

Belo Horizonte

Poisson

2020 
Editor Chefe: Dr. Darly Fernando Andrade

\section{Conselho Editorial}

Dr. Antônio Artur de Souza - Universidade Federal de Minas Gerais

Ms. Davilson Eduardo Andrade

Dra. Elizângela de Jesus Oliveira - Universidade Federal do Amazonas

Msc. Fabiane dos Santos

Dr. José Eduardo Ferreira Lopes - Universidade Federal de Uberlândia

Dr. Otaviano Francisco Neves - Pontifícia Universidade Católica de Minas Gerais

Dr. Luiz Cláudio de Lima - Universidade FUMEC

Dr. Nelson Ferreira Filho - Faculdades Kennedy

Ms. Valdiney Alves de Oliveira - Universidade Federal de Uberlândia

\begin{tabular}{|l} 
Dados Internacionais de Catalogação na Publicação (CIP) \\
E24 \\
Gucação Contemporânea - Volume 11 / Organização: JESUS, Bruna \\
Formato: PDF \\
ISBN: 978-65-5866-013-2 \\
DOI: 10.36229/978-65-5866-013-2 \\
Modo de acesso: World Wide Web \\
Inclui bibliografia \\
1.Metodologia 2.Educação 3. I.JESUS, Bruna Guzman. III.Título \\
\hline Sônia Márcia Soares de Moura - CRB 6/1896 \\
\hline
\end{tabular}

O conteúdo dos artigos e seus dados em sua forma, correção e confiabilidade são de responsabilidade exclusiva dos seus respectivos autores

$\underline{\text { www.poisson.com.br }}$

contato@poisson.com.br 


\section{SUMÁRIO}

Capítulo 1: Por uma gestão escolar democrática 06 Romilson Alves da Silva

DOI: $10.36229 / 978-65-5866-013-2 . C A P .01$

Capítulo 2: As contribuições da hermenêutica gadameriana para o processo ensino aprendizagem

Manoel Messias Gomes

DOI: $10.36229 / 978-65-5866-013-2 . C A P .02$

Capítulo 3: A filosofia para os gigantes da física: 0 perigo da ausência do pensamento crítico 28

Rafael Ferreira Fernandes, Júlio Pereira da Silva, Roberto Roque Antunes Oliveira

DOI: $10.36229 / 978-65-5866-013-2 . C A P .03$

Capítulo 4: Perfil psicomotor de uma criança de oito anos de idade: Estudo de caso 37 Maria Anailsa dos Santos Furtado Dias, Elaine Christina Monteiro de Oliveira, Noélia Kally Marinho de Sousa, Patrícia Emille Bento Gonçalves, Hilana Maria Braga Fernandes Abreu

DOI: $10.36229 / 978-65-5866-013-2 . C A P .04$

Capítulo 5: 0 ensino religioso na leitura e escrita no ato da criança 43

Maria Selta Pereira

DOI: 10.36229/978-65-5866-013-2.CAP.05

Capítulo 6: Educação por meio de vivência interdisciplinar: Relato de experiência.. 51 Ruth Nayara Firmino Soares, Jônia Cybele Santos Lima

DOI: $10.36229 / 978-65-5866-013-2 . C A P .06$

Capítulo 7: Compreendendo a dinâmica de sala de aula a partir do número de alunos em classe: Uma análise do desempenho escolar 59

Camila Fernanda Bassetto, Sebastião de Souza Lemes

DOI: 10.36229/978-65-5866-013-2.CAP.07

Capítulo 8: Bullying na concepção de professores do Ensino Fundamental I. 66

Dulcinéia da Silva Adorni, Fernanda Giselle Morais do Vale Cestari

DOI: 10.36229/978-65-5866-013-2.CAP.08 


\section{SUMÁRIO}

Capítulo 9: Um olhar reflexivo-formativo acerca do pensamento algébrico no Ensino Fundamental.

Marcos José Custódio Dias, José Aurimar dos Santos Angelim

DOI: 10.36229/978-65-5866-013-2.CAP.09

Capítulo 10: Lúdico: Entre o conceito e a realidade educativa 83

Ronara Viana Cordovil, Virgílio Bandeira do Nascimento Filho, José Camilo Ramos de Souza

DOI: $10.36229 / 978-65-5866-013-2 . C A P .10$

Capítulo 11: Formação de professores: Reflexões sobre o Plano Nacional de Formação de Professores da Educação Básica. 89

Cristiane Duque de Souza Pantoja, Mateus de Souza Coelho Filho

DOI: 10.36229/978-65-5866-013-2.CAP.11

Capítulo 12: Professor homem na educação infantil: 0 que eles têm a dizer sobre sua formação inicial? 102

Luciano Gonçalves Teodoro, Gisela do Carmo Lourencetti

DOI: $10.36229 / 978-65-5866-013-2 . C A P .12$

Capítulo 13: 0 livro didático como indicador de mudanças e transformações no Ensino de Ciências 110

Edna Luiza de Souza, Nilson Marcos Dias Garcia

DOI: 10.36229/978-65-5866-013-2.CAP.13

Capítulo 14: Percepção ambiental e relações de educação ambiental dos moradores residentes no entorno de lagoas na cidade de Zé Doca, Maranhão

Edimar Campelo Araújo, Osiel César da Trindade Junior

DOI: 10.36229/978-65-5866-013-2.CAP.14

Autores: 


\section{Capítulo 1}

\section{Por uma gestão escolar democrática}

\section{Romilson Alves da Silva}

Resumo: Esse estudo tem como foco a gestão democrática da escola pública, no sentido de compreender como o gestor desenvolve sua filosofia de trabalho no contexto escolar. A pesquisa visa também conhecer a realidade da escola, pois há gestores que não têm esse conhecimento prévio de valorizar os funcionários e alunos, através dos seus ideais, conhecimentos e potencialidades; vivenciar o trabalho desenvolvido pelo gestor e funcionários da escola; verificar como foi efetivada a escolha do gestor; investigar como o gestor desenvolve suas práticas na escola e propor uma gestão democrática, onde a comunidade escolar possa ser valorizada e respeitada. Adota-se o método descritivo analítico, dentro de uma abordagem qualitativa e quantitativa, através de questionários com perguntas objetivas e subjetivas, conversa formal e informal e entrevistas. Os sujeitos desta pesquisa foram: gestor, professores, alunos, pessoal de apoio, pais ou responsáveis. Percebe-se que a escolha do gestor em sua grande maioria, não é efetivada de maneira democrática, prejudicando assim o processo ensino-aprendizagem. Compreender que a gestão escolar democrática é importante, pois valoriza todos os funcionários e pais de alunos; um gestor democrático estimula os docentes a desenvolver seus conhecimentos e suas reflexões críticas.

Palavras-chave: Gestor. Democracia. Escola. Conhecimento. 


\section{INTRODUÇÃO}

A gestão escolar democrática tem características e exigências próprias, para desenvolvê-la devemos observar procedimentos que promovam o envolvimento, o comprometimento e a participação das pessoas.

Nesse contexto a gestão escolar democrática se faz necessária, uma vez que há escolas onde as práticas pedagógicas dos gestores não são aplicadas corretamente. Observando essas problemáticas em relação ao trabalho dos gestores, houve uma grande inquietação para pesquisar a gestão.

Na maioria das vezes, ocorre influência política em relação a escolha dos gestores escolares, a partir disso, é possível que seja escolhido um profissional sem competência para desenvolver tal atividade, comprometendo os trabalhos que são desenvolvidos na escola.

O Brasil é um país onde a desigualdade social está presente no cotidiano das pessoas, e falta informação para a população, o que faz com que as pessoas, não raramente, fiquem alheias a seus direitos e, consequentemente, a participação da população não se concretiza de maneira eficaz. Um país marcado por tantas desigualdades sociais e por uma tradição de autoritarismo, que eliminou dos processos de participação a maioria da população, mostra-se carente de canais institucionais de intervenção popular na definição das políticas públicas que possa reverter o quadro que hora se apresenta.

"A democracia designa um modo de vida numa sociedade em que se acredita que cada indivíduo tem direito de participar livremente dos valores dessa sociedade" Fulgêncio, (2007, p. 193). Verifica-se que num país onde as variedades sociais estão sempre atuais na sociedade, a educação tem uma função primordial que é uma formação da cidadania. Para isso, é preciso que as pessoas façam parte da comunidade escolar e estejam realmente envolvidos no processo democrático nos centros educacionais. Os gestores por sua vez, devem fazer com que haja democracia nas escolas e devem fazer com que exista a práxis nos seus trabalhos, porque na maioria das vezes, só existe muita argumentação e teoria por parte de gestores, mas no momento da prática há gestores que ficam atrapalhados com os trabalhos escolares, porque não têm competências e habilidades. Desse modo, a gestão democrática não pode ficar restrita ao discurso da participação e suas formas externas, as eleições e reuniões, terão que está a serviço dos objetivos do ensino, especialmente da qualidade cognitiva do processo de ensino e aprendizagem.

Dessa forma, a gestão escolar democrática é formidável, pois valoriza todos os funcionários e pais de alunos. Um gestor democrático estimula os docentes a desenvolver seus conhecimentos e suas reflexões críticas. 0 referencial teórico utilizado para fundamentar a pesquisa, compõe-se de: Azanha (1999), Alexandre Thomaz Vieira (2003), Constituição Federal (1988), Lei de Diretrizes e Bases da Educação Nacional (1996), Gaudêncio Frigoto, Cláudia Davis (2002), Licínio C. Lima (1996), Naura S. Carrapeto Ferreira (1998), José Carlos Libâneo (1999), Vitor Henrique Paro (2001), Paulo Roberto Padilha (1994), Saviani (1991), Vasconcelos (1995), Moacir Gadotti e José Romão (1997), Celso Antunes (1998) Fulgêncio (2007), Chiavenato (1983).

\section{DESENVOLVIMENTO}

\subsection{TEORIA GERAL DA ADMINISTRAÇÃO (TGA), E SUA IMPORTÂNCIA NA GESTÃO DEMOCRÁTICA}

Observa-se que a Teoria Geral da Administração (TGA), é uma disciplina eminentemente orientadora do comportamento profissional de administração. Essa disciplina ensina o futuro profissional a pensar, a raciocinar, a partir de conceitos e ideias que são trazidas como ferramenta de trabalho.

Segundo Taylor, os embasamentos da Administração Científica Chiavenato, (1983, p. 41), consiste em:

a. Estudo de tempo e padrões de produção;

b. Supervisão funcional;

c. Padronização de ferramentas e instrumentos;

d. Planejamento das tarefas e cargos;

e. Princípios da execução;

f. Utilização da régua de cálculo e de instrumentos para economizar tempo;

g. $\quad$ Fichas de instruções de serviços;

h. Prêmios de produção pela execução eficiente das tarefas;

i. Definição da rotina de trabalho. 
Pode-se afirmar que a administração escolar foi influenciada por dois aspectos, tanto na prática quanto na fundamentação teórica: 1ำ Conceitos de administração e organização, desenvolvida à luz das realidades diferentes da escola brasileira; $2^{\circ}$ Teorias administrativas ou organizacionais a partir de ambientes diferentes dos ambientes escolares.

Os principais teóricos sobre os conceitos e teorias de administração, são: Taylor e Fayol, cujas ideias se fundamentam a um tipo de organização que tem pouco ou nada a ver com a escola, Taylor enfatiza que o homem e o seu gosto pelo trabalho, as suas diferenças e o homem e o trabalho em grupo. Já para Fayol as experiências e práticas deram-se no campo industrial e em fábricas, tal como aconteceu com Taylor; As reflexões e recomendações de Fayol referem-se à cúpula da organização.

Verifica-se que estes teóricos não tinham muito a falar sobre a gestão escolar, mas foram eles que começaram a falar sobre gestão administrativa e que foram desenvolvidas para o campo da educação. Observa-se que os diretores participativos se baseiam no conceito de autoridade compartilhada, por meio de qual o poder é delegado à representação da comunidade escolar e as responsabilidades são assumidas em conjunto.

O desenvolvimento das práticas de gestão democrática e participativa a serviços de uma escola que priorize a aprendizagem dos alunos requer conhecimentos, habilidades e procedimentos práticos e eficazes. 0 trabalho nos centros educacionais envolve, ao mesmo tempo, processos de mudanças nas formas de gestão e mudanças nos modos individuais de pensar e agir. Ferreira (1998, p. 20), afirma que:

A participação na gestão da escola está, garantida teoricamente por meio do funcionamento Conselho Escolar, que é fruto de uma longa e persistente política do início dos anos 80 , com sentido de dar à escola autonomia para poder elaborar o seu projeto educativo.

A problemática que as escolas enfrentam no seu cotidiano é a falta de participação. Verifica-se que só um procedimento de troca de conhecimento e experiência pode encontrar os meios de enfrentá-los, e é a partir da observação dessa realidade que se pode considerar as ações a serem desenvolvidas com consciência e capazes de assumir um papel de caráter educativo em função do método de participação.

Observa-se também a necessidade do engajamento e a participação da coletividade na formulação, implementação e monitoramento de estratégias para a ampliação do ensino, assim como o desenvolvimento de sistemas de administração e de gestão educacional que sejam participativas e capazes de dar respostas e de prestar contas. Estes elementos contribuem para estabelecer novas relações entre a escola e comunidade local.

\section{0 GESTOR ESCOLAR}

Na visão democrática as qualidades dos gestores educacionais são: competência, liderança, autodisciplina, organização, motivação, justiça, bom senso, firmeza, inteligência, tolerância, perspicácia, educação, responsabilidade e que possam garantir com eficácia, objetivos da escola. Observe o que Alexandre Thomaz Vieira (2003, p. 36), fala a respeito do papel do gestor da atualidade.

“O papel do gestor escolar no atual contexto social é condição necessária, mas não suficiente, para a viabilização do processo de mudança organizacional e institucional almejado, uma vez que esbarra na rigidez dos limites estabelecidos pela máquina burocrática do sistema de ensino".

Dessa forma, compreende-se que umas das principais funções do gestor é responder por todas as atividades administrativas e pedagógicas da escola, assim como as atividades com os pais, comunidade e com outras instâncias da sociedade; e também organizar e coordenar as atividades de planejamento e do projeto político pedagógico, juntamente com a coordenação pedagógica, e fazer o acompanhamento, avaliação e controle da sua execução; supervisionar a avaliação da produtividade da escola em seu conjunto, incluindo a avaliação do Projeto Político Pedagógico, da organização escolar, do currículo e dos professores.

O gestor educacional deve ter competências, qualidades, funções, ações articuladas e conjuntas, visando um ensino de qualidade. Observa-se as quatro categorias que possam definir o processo de escolha do gestor: nomeação, concurso, esquema misto e eleição. 
A eleição favorece uma grande discussão democrática na escola e maior distribuição de poder, exigindo do diretor da escola o equilíbrio entre a competência técnica, acadêmica, a sensibilidade política e a liderança, e, consequentemente, favorece a gestão democrática e colegiada da escola.

As escolhas são fatores indispensáveis para a construção da democracia, apesar de não serem suficiente para assegurá-la. São várias as opções sobre quem será esse gestor, indo do mais tradicional e passando por outras alternativas, tais como: direções colegiadas e conselhos deliberativos, que contém ampla participação dos sujeitos envolvidos. Observa-se que é importante a relação e integração entre escola e comunidade, e o principal agente nesse processo é o gestor que terá que dispor de métodos e estratégias para fazer com que a comunidade participe da escola, principalmente os pais que não gostam dessa participação. De acordo com Mari, ex-professora:

"Da maneira como a escola trabalha, é para afastar mesmo o pai. Quer dizer, é uma coisa horrível a reunião de pais. Dificilmente você vê, assim, um aluno ser elogiado, na verdade, o pai é chamado e eles tremem assim ... porque é para malhar, é para dizer que não consegue aprender não consegue estudar..."

Desse modo, as pessoas que formam a comunidade, sentem-se desvalorizadas e desmotivadas com as pessoas da escola, afastando-se da mesma. 0 processo de envolvimento dos pais na escola necessita que o gestor aplique normas práticas que propiciem uma gestão participativa.

Paro (1997, p.16), esclarece que:

"Numa suposição de que a questão democrática das relações deve restringir-se as pessoas que atuam no âmbito do Estado sem se dar conta de, por mais colegiada que seja a administração da unidade escolar, se ela não inclui a comunidade, corre o risco de construir apenas mais arranjos entre os funcionários do Estado, para atender a interesses que, por isso mesmo, dificilmente coincidirão com os da população usuária".

Certamente se as pessoas participarem da escola, elas terão a chance de possuir um ensino de qualidade e condições para melhorar o estabelecimento. Portanto, a comunidade tem que fazer parte da escola, participar efetivamente, para que o ensino-aprendizagem se torne eficaz.

Compreende-se que o método democrático de gestão abrange o exercício do poder incluindo o planejamento, e o julgamento dos resultados obtidos; a gestão democrática tem por objetivo envolver os segmentos interessados na construção de propostas coletivas de educação.

Contudo, observa-se que há necessidade de pesquisar sobre o trabalho dos gestores, desenvolvidos em escolas públicas, pois se percebe que existem problemas pertinentes em relação ao trabalho dos gestores, como por exemplo, a dificuldade de interação com os demais funcionários.

No intuito de amenizar essas problemáticas relacionadas ao trabalho do gestor, a pesquisa irá discutir sobre a gestão democrática e consequentemente, possibilitar mecanismos para que o gestor possa ter um bom relacionamento com a comunidade escolar.

\section{A GESTÃo DEMOCRÁTICA}

A Constituição Federal em seu artigo 206, o ensino será ministrado com base nos seguintes princípios:

I. Igualdade de condição para o acesso e permanência na escola;

II. Liberdade de aprender, ensinar, pesquisar e divulgar o pensamento, a arte e o saber;

III. Pluralismo de ideias e de concepções e com coexistência de instituições públicas e privadas de ensino;

IV. Gratuidade de ensino público em estabelecimentos oficiais;

V. Valorização do profissional de ensino, garantido na forma da lei, plano de carreira para o magistério público, com piso salarial e ingresso, exclusivamente por concurso público de provas e títulos, assegurado regime jurídico único para todas as instituições mantidas pela união;

VI. Gestão democrática do ensino público, na forma da lei;

VII. Garantia de padrão de qualidade (BRASIL, 1988). 
Portanto, a Constituição Federal estabelece a gestão democrática do ensino público entre os sete princípios necessários para o desenvolvimento das atividades escolares.

No artigo 14 da Lei de Diretrizes e Bases da Educação (LDB), está claro que:

Os sistemas de ensino definirão as normas da gestão democrática do ensino público na educação básica; de acordo com suas peculiaridades e conforme os seguintes princípios:

A participação dos profissionais da educação na elaboração do projeto pedagógico da escola;

Participação das comunidades escolares locais do projeto pedagógico da escola (BRASIL, 1996).

Observa-se que o desafio de transformar a escola num espaço e local onde se vivencie a plenitude da democracia implica a construção de uma política pública que contemple a participação efetiva dos diversos fatores sociais do universo escolar: diretores, professores, alunos, pais e comunidades na formulação e na implementação da gestão democrática. Esse processo deve acontecer dentro dos colégios, como forma de eliminar conflitos ou divergências. Ele é parte intrínseca dessa construção e deve ser priorizado.

Em relação à pedagogia histórica-crítica que se empenha na defesa da especificidade da escola, Saviani, afirma que: "A escola tem função específica educativa, propriamente pedagógica, ligada à questão do conhecimento" Saviani, (1991, p. 101).

Como vemos, há diferentes formas de compreensão do papel da escola na sociedade, nesse sentido, a escola tem que fazer com que haja uma grande interação com a comunidade.

\section{O TRABALHO DO GESTOR NA ESCOLA}

Verifica-se que o Projeto Político Pedagógico da escola deve estar voltado para a inclusão dos problemas da escola e elaborado para tentar resolver esses problemas. Na verdade, o Projeto Político Pedagógico é a identidade de como a escola desenvolve suas atividades e metodologias. Veiga (1998, p. 11):

0 projeto pedagógico é um documento que não se reduz à dimensão pedagógica, nem muito menos ao conjunto de projetos e planos isolados de cada professor em sala de aula. 0 projeto pedagógico é, portanto, um produto específico que reflete a realidade da escola, situada em um contexto mais amplo que a influência e que pode ser por ela influenciado. Em suma, é um instrumento clarificador da ação educativa da escola em sua totalidade.

Assim sendo, o Projeto Político Pedagógico é muito importante para a escola, todavia, algumas instituições não têm esse documento, prejudicando assim todo o contexto escolar. Através do projeto, os professores podem estabelecer caminhos para nortear a execução da ação educativa.

Diogo (1998, p.17) diz que:

“O Projeto Político Pedagógico é claramente, um documento de planificação escolar que poderíamos caracterizar do seguinte modo: de longo prazo, quanto a sua duração; integral quanto à sua amplitude, na medida em que abarca todos os aspectos da realidade; flexível e aberto; democrático, porque é elaborado de forma participativa e resultado de consenso"

Nota-se então, que o Projeto Político Pedagógico envolve uma construção coletiva de conhecimento, no momento de sua elaboração, por sua vez, esse processo de construção é uma tentativa de resgatar os sentidos humanos, científicos e libertador do planejamento, Sacristán (1999, p. 61)

“O Currículo é a ligação entre a cultura e a sociedade exterior à escola e à educação; entre o conhecimento e a cultura herdados e a aprendizagem dos alunos entre a teoria (ideias, suposições e aspirações) e a prática possível, dada determinada condições."

Observa-se que o currículo guarda uma dimensão temporal e traduz ideia de percurso e de vivência, na verdade o currículo é algo a ser vivido no contexto educacional. 
De acordo com FORQUIM, (1996, p.190), o currículo é:

"A maneira pala qual uma sociedade seleciona, classifica, distribui, transmite e avalia os saberes educacionais destinados ao ensino, reflete a distribuição do poder em seu interior e a maneira pela qual se encontra aí assegurado controle social dos comportamentos individuais."

Observa-se que o currículo escolar é um documento que as escolas possuem para definir suas formas de trabalho, filosofia, seus objetivos e diretrizes de educação que se quer efetivar na escola. 0 currículo escolar é, portanto, a identidade da escola e engloba as atividades sistemáticas desenvolvidas pela escola, por todos os agentes educativos, voltados para a formação do cidadão em cumprimento formal do saber produzido e acumulado pela humanidade.

Verifica-se que a escola constitui um mundo com a cultura própria e rotinas praticamente universais, tudo isso converge para um protótipo de escola na qual prevalece a média e a qual todos os alunos devem ajustar-se. Nessa direção, a escola acaba por excluir alguns alunos. E, ao adotar determinadas atitudes, ao tomar determinadas decisões, ao realizar determinadas escolhas, a escola configura o seu currículo.

Consequentemente esse currículo pode está marcando positivamente ou negativamente a vida escolar de uma pessoa, e com certeza, o sucesso de alguns alunos e o fracasso de outros, sinalizam a urgência de se desvendar o currículo oculto da escola.

Constata-se que muitos educadores não gostam de planejar suas práticas pedagógicas, porém, quando estão desenvolvendo suas atividades escolares, ficam desnorteados e confusos. Azanha, (1993, p. 30):

“O significado do termo planejamento é muito ambíguo, mas no seu uso trivial ele compreende a ideia de que um mínimo de conhecimentos das condições existentes numa determinada situação e sem um esforço de previsão das alterações possíveis dessa situação, nenhuma ação de mudança será eficaz e eficiente, ainda que haja clareza ao respeito dos objetivos dessa ação. Nesse sentido trivial qualquer indivíduo razoavelmente equilibrado é um planejador.

Segundo Vasconcelos, (1995, p. 53), enfatiza sobre o planejamento:

“O planejamento da escola, enquanto outro nível de planejamento na educação escolar, é o que chamamos de Projeto Educativo, sendo o plano global da instituição. Compõe-se de marco referencial, diagnóstico e programação. Envolve tanto a dimensão pedagógica, quanto à comunitária e administrativa da escola".

Portanto, faz-se necessário a prática de planejar. Na maioria das vezes, os professores não têm tempo disponível, o que acaba por dificultar o ensino-aprendizagem.

Fusari, (1988, p.9), enfatiza que:

“O planejamento da educação escolar poder ser concebido como processo que envolve a prática docente no cotidiano escolar, durante todo o ano letivo, onde o trabalho de formação do aluno, através do currículo escolar, será priorizado. Assim, o planejamento envolve a fase anterior ao início das aulas, o durante e o depois, significando o exercício contínuo da ação-reflexão-ação, o que caracteriza o ser educador".

Como se pode observar, é preciso planejar, para que o educador possa fazer uma análise crítica das suas ações e intenções na escola, procurando desvendar os problemas do seu cotidiano pedagógico.

A avaliação deve ser contínua, observando o desenvolvimento, levando em conta as reflexões e criatividades dos alunos; a avaliação contínua e constante permite que um problema de aprendizagem seja detectado de modo a tomar as providências necessárias para superá-lo.

Existe uma grande discussão a respeito da avaliação. Para alguns pedagogos, nunca se pode dizer aos alunos que eles estão errados, quando o exercício ou prova apresentarem respostas erradas, porque essa atitude do professor irá prejudicar psicologicamente o aluno.

Segundo Cláudia Davis, a avaliação é: “condição essencial de qualquer ação intencional. Se implementarmos algo, com determinados objetivos, como saber se os resultados esperados foram alcançados?" Davis, (2002, p. 105). 
Conclui-se assim que um dos cuidados que se deve ter ao avaliar é não ferir a autoestima de ninguém. Por exemplo, não riscar trabalhos dos alunos, para não chamar atenção para o erro, o mais importante é observar a reflexão e ideias dos discentes, se é errado orientar os alunos, se é correto elogiá-los.

Essa é uma pergunta que naturalmente surge em várias reflexões. Pensando na atual tendência pedagógica crítica social dos conteúdos, faz-se necessário uma escola democrática e que possa formar alunos críticos e reflexivos.

Segundo Lima (1996, p. 31):

“A subjugação total da escola à imposição, levada a cabo pelo Estado e pelos sistemas globais de controle, transforma-a num campo de reprodução condenando os atores se os despojando das suas margens de autonomia e liberdade das suas capacidades estratégicas(...), a escola não será apenas uma instância hetero-organizada para a reprodução, mas será também uma instância auto organizada para a reprodução de regras e a tomada de decisões, expressão possível de atualização de estratégias e de usos de margens de autonomia dos atores".

\section{PORTANTO, QUE ESCOLA QUEREMOS? QUEREMOS UMA ESCOLA QUE...}

- Que promova a integração da diversidade cultural, fazendo com que se efetive uma educação multicultural e comunitária;

- Uma escola que cuida da formação da qualidade moral, caráter, responsabilidade e criatividade;

- Que desenvolva os processos de formação para a cidadania, de modo a criar novas práticas de gestão. Uma escola que possa criar situações para uma educação de responsabilidade, participação, competência e habilidades de liderança e tomada de decisões;

- Assegurar o direito à escolarização de crianças, jovens e pessoas adultas sem exceção de raça, cor, etc.;

- Uma escola que se adapte a novas tecnologias;

- Uma escola bem estruturada, física e pedagogicamente, que assegure o direito dos alunos à educação;

- Uma escola que possa garantir a formação dos professores, e remuneração digna a esses funcionários.

Celso Antunes 1998, p.13, afirma que:

“A nova escola é a que assume o papel de central estímulo de inteligência. Se a criança já não precisa ir à escola para simplesmente, aprender, ela necessita da escolaridade para aprender, desenvolver suas habilidades e estímulo suas inteligências".

Queremos uma escola que possa atender todas as necessidades possíveis e resolver todos os problemas existentes. Além disso, a escola precisa comprometer-se com a transformação social e deve lançar mão de princípios, métodos e técnicas adequadas à especificidade dos seus objetivos e do processo pedagógico.

Neste enfoque, percebe-se a necessidade da participação de todos na construção da proposta de uma gestão participativa e democrática, evidenciando o desafio tanto para as secretarias, quanto para as lideranças das escolas públicas, no que se refere ao relacionamento com as famílias dos alunos nas reuniões para conversar sobre indisciplina e notas baixas, de maneira a participar sistematicamente da vida de seus filhos.

É preciso ainda definir com clareza e responsabilidade que cada um deve assumir o seu trabalho: o diretor, os professores, alunos, pais, pessoal de apoio, liderança de comunidade e deve ter cuidado para não confundir as atribuições, e que a comunidade escolar possa desenvolver com competências e habilidade os principais problemas encontrados na escola.

Os principais problemas que uma gestão democrática enfrenta na escola, são: falta de interesse de educandos e educadores; dificuldade de ensino e aprendizagem nas diversas disciplinas; evasão; falta de recursos financeiros e humanos, como por exemplo: especialistas em educação, bibliotecários, psicólogos, psicopedagogos, entre outros. 
Entende-se que existe um amontoado de problemáticas no contexto escolar, e que no mundo capitalista a escola deve estar preparada para atender alunos e profissionais com os mais diversos problemas e sanálos para que todas as pessoas possam sentir-se valorizadas e respeitadas democraticamente.

A democracia já foi definida, Paro (2000, p. 27), como:

"Um conjunto de procedimentos para poder conviver racionalmente, adotando de sentido uma sociedade cujo destino é aberto, porque acima do poder soberano do povo já não há nenhum poder, são os cidadãos livres que determinam a si mesmo como indivíduos e coletivamente, "

\section{RESULTADOS E DISCUSSÕES}

A pesquisa foi realizada numa instituição de ensino infantil e ensino fundamental, pública municipal, a fim de obter respostas das perguntas à gestão escolar democrática. A pesquisa foi feita através de questionários, direcionada a cinco categorias (gestor, professor, corpo de apoio, pais e alunos).

As entrevistas, os debates, as conversas formais foram efetivadas na instituição; os questionários continham perguntas de múltiplas escolhas e perguntas analíticas discursivas para cada categoria.

O foco desta pesquisa é investigar o trabalho do gestor escolar e verificar se, de fato, ocorrem práticas democráticas no contexto educacional, mas, foi possível perceber o quanto está longe de se conseguir a participação da comunidade e escola à gestão democrática em todas as suas instâncias. Neste enfoque, percebe-se a importância da participação de todos os envolvidos na construção da proposta de uma gestão participativa e democrática, evidenciando o desafio tanto para as secretarias, quanto às lideranças das escolas públicas no que se refere ao relacionamento com as famílias dos alunos nas reuniões para interagir sobre indisciplina e notas baixas dos alunos, de maneira a participar sistematicamente da vida de seus filhos.

Dessa forma, é preciso ainda definir com clareza e responsabilidade que cada um deve assumir o seu trabalho: o diretor, os professores, alunos, pais, corpo de apoio, liderança de comunidade; com o devido cuidado para não confundir as atribuições, e que a comunidade escolar possa desenvolvê-las com competências e habilidades.

Segue abaixo o que foi explicitado acerca da gestão democrática por todos os sujeitos arrolados na pesquisa:

Observa-se o que os gestores da instituição expuseram nas entrevistas. Foi perguntado se há estímulos por parte da gestão ao trabalho do professor e se tem atividades e projetos na escola.

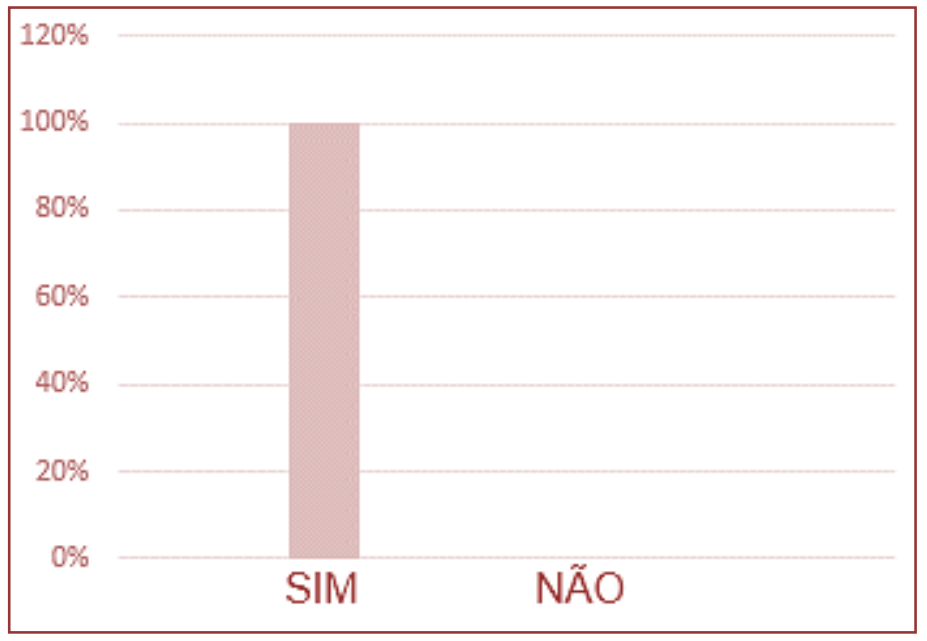

Através do gráfico acima pode-se perceber que as gestoras responderam que estão desenvolvendo vários projetos de ajuda aos trabalhos dos alunos, por exemplos: encontros pedagógicos, formações, entre outros, para que os mesmos aperfeiçoem suas metodologias e práticas pedagógicas na escola. 
Como se dá o relacionamento do gestor com a comunidade escolar? Verifica-se que o relacionamento entre a escola e comunidade, são de excelência, e as diretoras desenvolvem suas atividades, para que a interação entre escola e comunidade seja eficaz.

Que subsídios a escola fornece para que os alunos, professores, gestores e pais obtenham um bom relacionamento? Como isso ocorre? Observa-se que os relacionamentos dos profissionais no centro educacional são de excelência, e quando há divergências, a gestão desenvolve atividades para sanar os problemas, como: diálogo, debates para encontrar a solução mais adequada. Segundo as entrevistadas, esses trabalhos só terão resultado a longo prazo.

Quais os principais problemas encontrados na escola? Segundo as gestoras, os principais problemas apresentados são: falta de interesse de educandos e educadores; dificuldade de ensino e aprendizagem nas diversas disciplinas; evasão; falta de recursos financeiros e humanos, como por exemplo: orientadores, supervisores, bibliotecários, etc.

Conclui-se, portanto, que existe um amontoado de problemáticas no contexto escolar, e que no mundo capitalista a escola deve estar preparada para atender alunos e profissionais com os mais diversos problemas e buscar superá-los para que todas as pessoas possam sentir-se valorizadas e respeitadas democraticamente.

A democracia já foi definida, como:

Um conjunto de procedimentos para poder conviver racionalmente, adotando de sentido uma sociedade cujo destino é aberto, por que acima do poder soberano do povo já não há nenhum poder, são os cidadãos livres que determinam a si mesmo como indivíduos e coletivamente (PARO,2000, p. 27).

Foi perguntado as gestoras, se existe na escola o Projeto Político Pedagógico. A escola tem o Projeto Político Pedagógico, o documento foi elaborado de forma democrática, sendo ouvidas todas as pessoas que fazem parte da escola, como também pais de alunos, sempre dando vez e voz a todos de forma democrática.

Verifica-se o que os professores arrolados na pesquisa explanaram. Foi perguntado sobre a importância da relação do gestor com os professores. É evidente que o relacionamento entre gestor e professores é crucial para que haja um bom desempenho pedagógico na escola, a fim obter um excepcional desenvolvimento nos trabalhos, isso será de grande relevância para que o processo de ensino aprendizagem seja eficiente.

O gestor foi escolhido de forma democrática para trabalhar na escola? Esse questionamento dividiu a opinião dos educadores. Para alguns, os atuais gestores foram escolhidos democraticamente, já para outros professores, a escolha das gestoras não se deu democraticamente, houve intervenção política.

O gráfico abaixo demonstra a opinião dos professores sobre a ajuda das gestoras nos problemas encontrados na escola. Ressalta-se que as gestoras, ajudam os docentes nos mais diversos problemas encontrados na escola pesquisada.

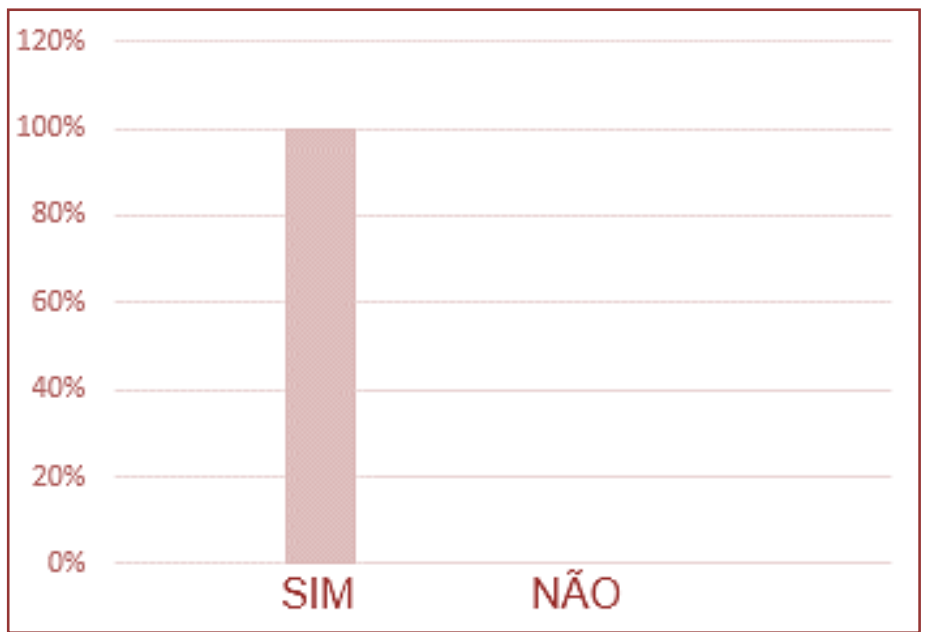


Em relação a gestão democrática, qual sua contribuição na escola? Os docentes responderam que colaboram para que a gestão democrática seja efetivada na escola, contribuem através de reunião, projetos para que todas as pessoas da comunidade escolar sejam respeitadas e valorizadas.

Constata-se o que o pessoal de apoio expusera sobre a gestão democrática na escola. As pessoas que fazem parte do corpo de apoio, são: serventes, vigias, merendeiras, auxiliares de serviços gerais (ACS), auxiliares de secretaria e digitadores. Segundo os mesmos, as gestoras desenvolvem projetos para o aprimoramento dos funcionários do corpo de apoio. Através dos projetos e planos de trabalho, os gestores estimulam os funcionários do corpo de apoio a desenvolverem um excelente trabalho na escola. Em relação aos trabalhos desenvolvidos pelo gestor na escola e sua contribuição.

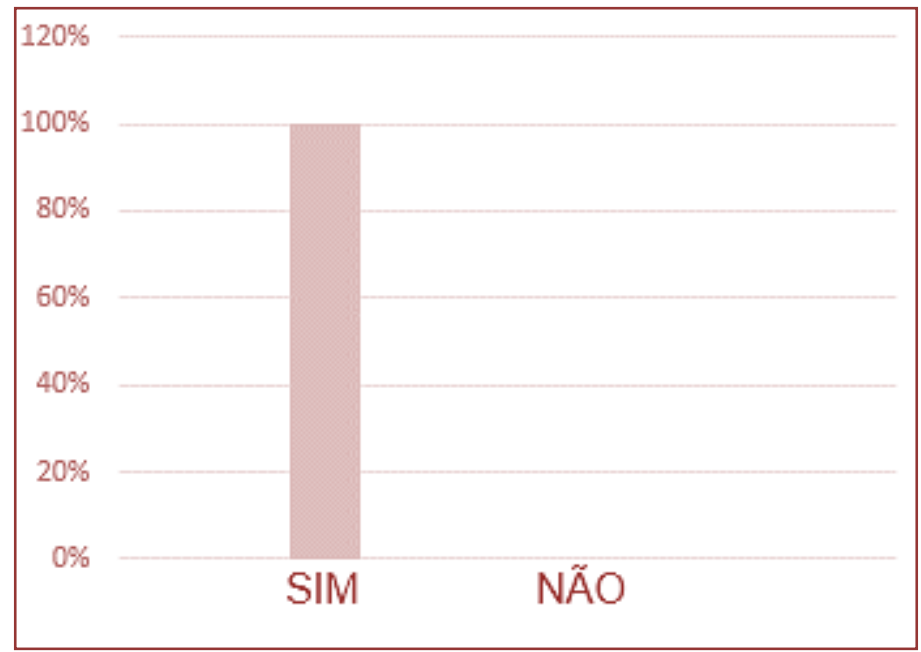

Analisando o gráfico acima pode-se observar que os funcionários do corpo de apoio falaram que colaboram com os trabalhos desenvolvidos pelos gestores na escola, contribuem dando opiniões, ajudando nas atividades de criação, elaboração e execução dos projetos. Foi perguntado. Você contribui para que a gestão escolar democrática seja realmente implementada na escola? Os funcionários disseram que contribuem para que haja a gestão democrática no contexto escolar, respeitando os alunos, professores e diretores.

O que você acha do ensino público? Observa-se que alguns profissionais da educação que trabalham no sistema público de ensino não valorizam a escola pública, na verdade, boa parte desses profissionais parecem não acreditar no sistema de ensino onde trabalham. Existem professores que falam sobre a importância dos valores da escola pública, mas na realidade põem seus filhos para estudar em escolas particulares, tornando assim simplesmente uma ideologia.

O desenvolvimento do educador é influenciado pela efetivação da democracia na escola? Com certeza, os trabalhos dos professores são efetivados com mais eficácia, existindo a democracia no contexto escolar.

Veja como os alunos contribuíram para a pesquisa. Foi perguntado como se dá o relacionamento, essa interação entre gestor e aluno. Para os mesmos, o relacionamento é excepcional, os alunos gostam e acreditam nas atividades propostas pela escola, segundo eles existem respeito, amizade, com isso o processo de interação entre aluno e gestor é efetivado de forma eficaz. 
As atividades desenvolvidas pelo gestor ajudam no processo de ensino- aprendizagem?

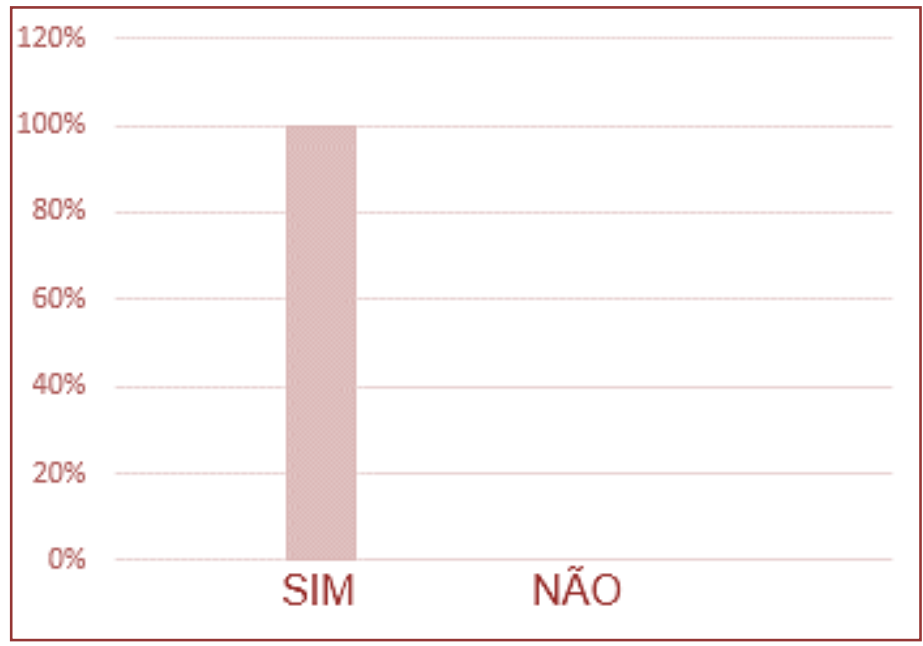

Com base no gráfico acima, para os alunos, as atividades desenvolvidas pelos gestores, com certeza ajudam no processo de ensino e aprendizagem, ou seja, os projetos das gestoras estimulam a aprendizagem dos alunos.

Para você o gestor desenvolve projetos para melhorar o processo de ensino e aprendizagem na escola? Como isso ocorre? Para os alunos, as gestoras propõem aos professores que elaborem projetos para melhorar a aprendizagem dos alunos, incentivando-os a dar opiniões para que possam aperfeiçoar seus conhecimentos e estimular sua visão crítica. E com isso os alunos acreditam que os projetos desenvolvidos pelos gestores ajudam na construção do processo de aprendizagem.

Foi pedido exemplos de projetos desenvolvidos pelo gestor que os alunos mais gostam. Verifica-se que são desenvolvidos vários projetos na escola, como: gincana escola, miniolimpíadas, feira do conhecimento, entre outros. Esses projetos têm temas importantes e com certeza os alunos irão aperfeiçoar seus conhecimentos, e os alunos gostam de participar desses projetos.

Para os alunos, a democracia é quando as pessoas seguem princípios e a distribuição equitativa das suas opiniões, mas, respeitando as condições das pessoas, suas atitudes e pensamentos. As atividades desenvolvidas pelos educadores explicitam a democracia e a cidadania dentro da escola? Os educadores desenvolvem várias atividades explicitando a democracia e a cidadania na escola. Eles desenvolvem projetos, ajuda os alunos no dia a dia na escola.

Você contribui para que a escola possa exercer a democracia? Os alunos responderam que ajudam e contribuem para que possa haver democracia no contexto escolar, mas há alunos que não sabe o que é democracia, como é que eles podem contribuir? 
Segue abaixo o gráfico que ilustra a contribuição dos pais para a pesquisa. Foi perguntado aos mesmos se as gestoras desenvolvem um bom trabalho na escola.

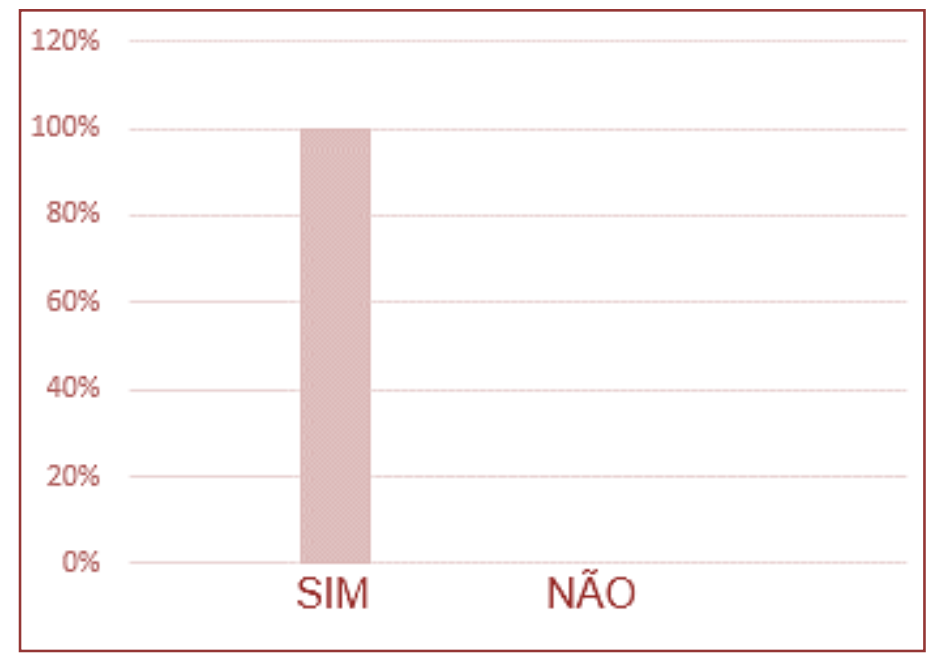

Segundo os pais, as gestoras da escola desenvolvem um excelente trabalho, têm uma vasta experiência na gestão escolar e sempre procura atender, conhecer e sanar os problemas da escola.

Como é o relacionamento dos seus filhos (alunos) e o gestor? Observa-se que, para os pais o relacionamento entre gestor e alunos se dá muito bem, as diretoras procuram conversar com os alunos com problemas, ajudam os alunos com problemas de aprendizagem.

O que você acha da gestão democrática? Muitos pais não conhecem muito sobre a gestão democrática, mas procuramos informá-los sobre este assunto que está sendo muito discutido em nossa região. A democracia é algo relevante na escola, pois vivemos num país democrático, porém muitas vezes não temos direito de falarmos o que pensamos. Como é de conhecimentos de muitos, há diretores que são escolhidos por políticos, dificultando assim o processo de relacionamento, aprendizagem e até mesmo o processo democrático dentro da escola. Muitas vezes são escolhidos diretores que não conhecem a realidade da escola e dos alunos.

As atividades desenvolvidas pelos educadores explicitam a democracia e a cidadania dentro da escola? Segundo os pais, os professores desenvolvem suas práticas pedagógicas, explicitando a democracia e cidadania e, com certeza, esses conhecimentos serão importantes na vida pessoal e profissional dos alunos. Você contribui para que a escola possa exercer a democracia? Os pais contribuem na democracia escolar, participando de reuniões, projetos e atividades na escola.

Portanto, a gestão democrática é essencial nas escolas do país, pois ajuda a democratizar o ensino e aprendizagem e permite que todos participem da escolha da gestão, fazendo com que as pessoas tenham seus direitos respeitados.

\section{CONSIDERAÇõES FINAIS}

Considera-se que a gestão democrática é essencial no contexto educacional atual, visto que as pessoas que trabalham nos centros educacionais são importantes para o processo de ensino e aprendizagem.

Entretanto, encontra-se uma diversidade de obstáculos, nesse modo democrático de gestão, que por sua vez ganham bastantes culpados: professores, pais, alunos, que não podem ser individualmente culpados, evidenciando assim falta de diálogo entre a escola e comunidade local.

Cada uma dessas razões faz com que o diretor exerça suas funções e adquira novo perfil. Então o papel da escola é de promover uma educação de qualidade que abrange os processos formativos que se desenvolvem na família, na convivência humana, no trabalho, nos movimentos sociais, entre outros.

Dessa forma, a gestão escolar democrática é de grande relevância, sendo que na maioria das vezes, os diretores são eleitos, outra grande maioria, é escolhida por políticos e, infelizmente, a política partidária atrapalha no desenvolvimento dos trabalhos dos gestores escolares. 
Os gestores escolares costumam ter problemas no desenvolvimento de suas atividades, dentre eles podemos destacar os seguintes: porque nem sempre a escolha do gestor é efetivada de maneira democrática? Porque na maioria das vezes os gestores não conhecem a realidade da escola? Como sanar a problemática do relacionamento entre gestor na escola? Qual a opinião dos funcionários em relação ao trabalho gestor? Porque na maioria das vezes há intervenção do meio político na escolha e no desenvolvimento do trabalho dos gestores nas escolas?

Faz-se necessário então, que os gestores possam compreender a comunidade escolar na qual estão inseridos, para que os seus projetos sejam efetivados de maneira eficaz, visto que há gestores que não têm um relacionamento harmonioso com os funcionários da escola e pais de alunos.

Através desta pesquisa, destacam-se diversas propostas de intervenção, em relação ao trabalho do gestor na escola, por exemplo: Fazer dinâmicas educativas, para que as relações interpessoais possam ser as melhores possíveis; promover eleições para escolha do gestor, e que todos os candidatos possam ter formação acadêmica para o cargo; conhecer o planejamento pedagógico dos gestores para o trabalho na escola; supervisionar e responder por todas as atividades administrativas e pedagógicas da escola, bem como as atividades com pais e comunidade e com outras instâncias da sociedade civil; assegurar as condições e meios de manutenção de um ambiente de trabalho favorável e de condições materiais necessárias à consecução dos objetivos da escola, incluindo a responsabilidade pelo patrimônio e sua adequada utilização; promover a integração e a articulação entre a escola e a comunidade próxima, com apoio e iniciativa do Conselho da Escola, mediante atividades de cunho pedagógico, científico, social, esportivo e cultural; garantir a aplicação das diretrizes de funcionamento da instituição e das normas disciplinares, apurando ou fazendo apurar irregularidades de qualquer natureza, de forma transparente e explicita, mantendo a comunidade escolar sistematicamente informada das medidas; supervisionar a avaliação da produtividade da escola em seu conjunto, incluindo a avaliação do projeto político pedagógico, da organização escolar, do currículo e dos professores; buscar todos os meios e condições que favoreçam a atividade profissional dos professores, dos funcionários, visando a boa qualidade do ensino; supervisionar e responsabilizar-se pela organização financeira e controle das despesas da escola, em comum acordo como Conselho de Escola e professores; conhecer a legislação educacional e do ensino, as normas emitidas pelo órgão competentes e o Regimento Escolar, assegurando o seu cumprimento; organizar e coordenar as atividades de planejamento e do projeto político pedagógico, juntamente com a coordenação pedagógica, bem como fazer acompanhamento, avaliação e controle de sua execução; coordenar, organizar e gerenciar todas as atividades da escola; assegurar o processo participativo de tomada de decisões; estabelecer um clima de trabalho favorável ao desempenho das tarefas; articular as relações interpessoais na escola, entre a escola e comunidade e garantir a eficácia na utilização dos recursos e meios, em função dos objetivos da escola.

Finalizo dizendo que a gestão escolar democrática é primordial nas escolas públicas, favorece desde ao alunado, professores, funcionários de apoio até os pais. A escolha de um gestor escolar de forma democrática é algo que devemos buscar e implementar na realidade das escolas do país, visando uma educação de qualidade nesses contextos educacionais.

\section{REFERÊNCIAS}

[1] BRASIL. Lei no 9.394 de 20/12/1996. Estabelece as Diretrizes e Bases da Educação Nacional.

[2] _ C C Constituição Federal de 1988. Brasília D.O.U. 05/10/1988.

[3] CHIAVENATO, Idalberto (1983). Introdução à Teoria Geral da Administração. 3o Edição. São Paulo: McGrawHill do Brasil.

[4] DAVIS, Claudia (et al); VIEIRA, Sofia Lerche (org.) Gestão da Escola: desafios as enfrentar. Rio de Janeiro. DPEA, 2002.

[5] DIOGO, Fernando. Por um projeto educativo de rede. Lisboa: Asa, 1998.

[6] FERREIRA, Naura S. Carrapeto (org.) Gestão Democrática da Educação: Atuais Tendências, Novos Desafios. São Paulo.Cortez,1998.

[7] FULGÊNCIO, Paulo César. Glossário: Vade Mecum. Rio de Janeiro: Mauad, 2007.

[8] GADOTTI, Moacir Romão, José E. (org.). Autonomia da escola princípios e proposições, 4o Ed. São Paulo, Editora Cortez, 1997.

[9] LIBÂNEO, José Carlos. Organização e Gestão da Escola. Teoria e Prática. Goiânia: Alternativa, 2003. 
[10] PARO, Vitor Henrique: Gestão Democrática da Escola Pública. 3ํㅡ. Ed. São Paulo: Ática, 2001.

[11] _ _ Vitor Henrique: Gestão da Escola Pública: a Participação da Comunidade, R. bras. Est. pedag. Brasília. V 73, n.l 74, p.255-290, maio/ago. 1992

[12] SACRISTAN, J. Gimeno. Poderes instáveis em educação. Tradução de Beatriz Affonso Neves. Porto Alegre: Artmed, 1999.

[13] VEIGA, I. P. A. (Org.). Projeto político-pedagógico da escola: uma construção possível. 23 ed. Campinas: Papirus, 2001.

[14] VIEIRA, Alexandra Thomaz. (org.). Gestão Educacional e Tecnológica. São Paulo: Avercamp, 2033.

[15] VASCONCELOS, Celso. Planejamento: Projeto de Ensino-Aprendizagem e Político Pedagógico. Liberdtad, 7o Edição, 2000. 


\section{Capítulo 2}

As contribuições da hermenêutica gadameriana para o processo ensino - aprendizagem

\section{Manoel Messias Gomes}

Resumo: 0 presente artigo busca apresentar os resultados de uma pesquisa bibliográfica sobre a importância da hermenêutica filosófica de Gadamer e suas contribuições para a educação, destacando, principalmente,os conceitos de diálogo, de experiência e de compreensão, como conceitos chaves da hermenêutica filosófica e que se aplicam à educação de maneira singular. Destacando, portanto, as contribuições da Gadamer para a filosofia e para a educação, mostrando a importância da experiência e a possibilidade de, através dela, de uma educação para a transformação de sentidos.

Palavras-Chave: Hermenêutica filosófica, experiência, educação, transformação. 


\section{INTRODUÇÃO}

O presente trabalho é fruto de uma pesquisa bibliográfica sobre a importância das contribuições da hermenêutica gadameriana para o processo de ensino e aprendizagem, mostrando como a investigação do pensamento de Gadamer indica a linguagem como possibilitadora do diálogo e, conseqüentemente da aprendizagem, tendo o diálogo como um "atributo natural do homem". Em que, pode-se perceber que, a linguagem "se desenvolve entre os seres humanos de forma viva". Onde se pode perceber também, que a aprendizagem só se dá efetivamente, quando existe uma " fusão de horizontes", intermediado pela linguagem, entre o horizonte do educador e o do educando. Pois, sem essa "fusão de horizontes", entendida como fusão de concepções, o processo de ensino e aprendizagem perde o sentido. Portanto, compreende-se que a hermenêutica filosófica de Gadamer, pode contribuir como um grande potencial de descoberta e de abertura intelectual, permitindo aos atores de processo educativo (por meio da linguagem), chegar à aprendizagem, ultrapassando os obstáculos procedimental-metodológicos da razão e da lógica que caracterizam o modo de ser das ciências positivistas. Obstáculos estes, que podem ser ultrapassados por meio do diálogo, que possui o poder de compreender o mundo e os objetos, pelo viés dos sentidos. Por isso, Gadamer assinala, que o processo educativo se dá pela interação, mediada pela linguagem, com os outros indivíduos, mostrando que a linguagem apresenta-se como meio que facilita e que articula as experiências da compreensão, constituindo-se como uma forma de abertura à significação em que a produção de sentidos se dá por meio do diálogo e da interpretação, numa perspectiva de produção de conhecimentos, chamada de "compreensiva", em oposição à via "explicativa". Pois, é através da via "compreensiva", que o conhecimento, segundo ele, é construído por meio de uma relação de diálogo mútuo entre os envolvidos.

\section{A HERMENÊUTICA DE GADAMER}

Hans - Georg Gadamer, nascido em 2 de fevereiro de 1900 e falecido em 13 de março de 2000, foi um filósofo alemão e o principal representante da corrente hermenêutica em seu país. Segundo o professor Raimundo José Alves Cruz, em seu artigo "Hermenêutica e educação: o sentido gadameriano de diálogo ressignificando as relações pedagógicas", Gadamer foi aluno de Heidegger e sucedeu Karl Jasper na cadeira de filosofia da universidade de Heidelberg (1949). O seu pensamento encontra-se marcado pelas influências de Diltey, Heidegger e de toda uma tradição da hermenêutica alemã, tendo procurado com seus trabalhos desenvolver uma tentativa de interpretação do ser histórico através de sua manifestação na linguagem, uma vez que esta se apresenta em seu pensamento como uma forma básica da experiência humana.

Para o professor Raimundo José, esse processo iniciou-se em 1918, quando Gadamer deixa o Instituto do espírito santo, em Breslau, e no último ano da primeira guerra mundial, realiza suas primeiras visitas à Universidade de Breslau. Filho de um ortodoxo pesquisador das ciências naturais, teve de conviver com o sentimento de decepção por parte do seu pai, por não aceitar o seu desinteresse por tais estudos. Como ele mesmo afirma: " isso porque soube desde o começo de meus estudos universitários, que eu simpatizava com os 'professores charlatães'. Ele não impediu, mas durante toda a sua vida esteve decepcionado comigo"( GADAMER, apud CRUZ, 2002, p. 545).

Segundo esse autor, Gadamer parte da historicidade hermenêutica de Diltey. Mas a fenomenologia de Russerl e principalmente a virada filosófica de Heidegger, possibilitam outra radicalidade ao seu pensamento, no qual a própria dicotomia sujeito-objeto é rompida em prol de uma construção que se realiza a partir do diálogo entre os homens que vai criando tradições sucessivas na história, mediada pela linguagem. Linguagem que, para Gadamer, "é o meio em que se realiza o acordo dos interlocutores e o entendimento sobre a coisa". Sobre essa base, se fundamenta "a comunidade entre os homens e em seu consenso sobre o que é bom e correto" (GADAMER, apud CRUZ, 2002, p. 36).

É importante, para a compreensão do pensamento de Gadamer, entender que não se pode pensar numa verdade além da linguagem. Ao contrário, ela é construída, dentro da história da construção humana. Segundo Cruz, a linguagem em Gadamer é, acima de tudo, diálogo. E o diálogo hermenêutico se faz necessário especialmente quando se lida com uma tradição que não é a nossa, por distâncias que se estabelecem a partir do tempo, da relação com outros povos ou mesmo a partir da estranheza que surge da nossa relação com qualquer um. Somos ao mesmo tempo, comuns e estranhos ao outro. Por isso podemos nos comunicar,temos de transpor as distâncias, e daí a necessidade da hermenêutica. 
Em 1945, após anos como estudante e docente em Marburgo, Gadamer aceita o convite para a sucessão de Kalr Jasper em Heidelberg. É um momento favorável à concentração em seus planos de trabalho, resultando em 1960, em sua obra monumental Verdade e Método. Sendo o debate levado em frente por Gadamer em três esferas, as quais, encontram-se presentes na experiência hermenêutica: a esfera da estética, a esfera histórica e a esfera da linguagem. Em sua filosofia encontramos os traços fundamentais de uma hermenêutica filosófica, e junto à sua teoria, conceitos-chaves, tais como o sentimento de pertença e familiaridade a uma determinada tradição.

Esses conceitos trabalhados por Gadamer surgem exatamente contra o distanciamento alienado que é provocado pelo modo de proceder da ciência moderna. Sua intenção é tematizar a compreensão da experiência humana no mundo, mundo este, que desde já se dá interpretado. Portanto, a hermenêutica gadameriana procura se afirmar como uma racionalidade. Sendo que as exigências de tal racionalidade surgem exatamente da oposição a uma época onde a procura pelo saber segue de forma estreita a racionalidade dos procedimentos empírico-formais. Portanto, a hermenêutica procura propor um exercício metodológico adequado às ciências humanas. "Sendo que, segundo Hermann, a hermenêutica gadameriana" quer fazer valer o fenômeno da compreensão diante da pretensão de universalidade da metodologia científica "(HERMANN, 2002, p. 16). Portanto, tratar do diálogo hermenêutico exige a consciência de todo o processo histórico, e do esforço próprio da hermenêutica que se constitui em superar a objetividade estática das ciências naturais e apresentar um novo modelo de se relacionar, onde o diálogo hermenêutico mantém-se como elo principal da compreensão.

Com a hermenêutica filosófica, a verdade perde a qualidade de estável, justamente por que a interpretação é uma possibilidade. Pois, "sendo possível interpretar uma determinada proposição, põe-se logicamente, em risco a verdade" (RUEDEL apud Cruz, 2000, p. 49). Para isso, o saber perguntar, na estrutura dialógica da hermenêutica filosófica, mobiliza novas relações de sentido, podendo ampliar o campo de visão e o próprio horizonte interpretativo, que marca uma determinada maneira de compreender. Assim, a educação pode ser pensada justamente como a ação e o movimento onde ocorre a formação ou a mudança nas articulações dos sentidos. 0 critério de avaliação e auto-avaliação, no que se refere à maneira de se compreender, e voltam para a superação do movimento que se dá de forma solitária, ou de pouca abrangência, tendo o horizonte mais próximo como referência. Pois, quando Gadamer ratifica a necessidade de abertura ao diálogo e à tradição, soa como uma condição para que se construa uma verdade compartilhada.

\section{A ESTRUTURA DIALÓGICA DA COMPREENSÃO}

Do ponto de vista educacional, as relações e o reconhecimento de si mesmo diante do outro dialogam internamente. Segundo o professor Daniel José Crocoli, em seu artigo Contribuições da Hermenêutica Filosófica de Hans Georg Gadamer para a Educação, "talvez este seja um diálogo a partir do qual muitas das decisões pessoais e de orientação da própria vida sejam tomadas" (CROCOLI, 2012, p. 03). Por que, a recusa, a não aceitação em se colocar no diálogo ou a postura frente ao diálogo, já revelam um movimento dialógico anterior do qual brota a decisão. Por isso, Gadamer faz a afirmação de que "[...] não é possível 'fazer duas vezes a mesma experiência" (2008, p. 462). Portanto, significa que o chamamento e a reivindicação para que haja uma representatividade de uma experiência, se tornam experiências em uma situação nova, em uma temporalidade diferente. Esta originalidade da experiência mostra o quanto se podem ampliar o horizonte da visão e os limites do que se considera compreendido.

A hermenêutica, através do conceito de experiência, indica que o controle ou o sujeito da compreensão não está na consciência, que se dá como diálogo. Ao saber-se, sempre lhe escapa o controle da mobilidade do diálogo. 0 envolvimento do homem com o mundo, com os outros e consigo mesmo não é neutro, sempre acontece a partir de uma história e de um envolvimento. A compreensão de si institui uma relação de verdade que evidencia um nível de desvelamento do sujeito para consigo mesmo, de suas capacidades e de suas habilidades.

Ter experiência é ter a capacidadede reconhecer-se enquanto seres finitos e históricos. Esta é a condição principal para o autêntico diálogo capaz de manter o pensar em uma atividade produtora do saber, pois o experienciado mantém abertas as possibilidades do saber, não se contentando com o que já se mostrou, como desvelamento. Portanto, toda nova experiência instaura novos horizontes de compreensão e, a descoberta não esgota as possibilidades de novas e diferentes relações. 0 responder se enquadra como uma das maneiras de contemplar a pergunta, sempre inserido em um horizonte de compreensão, marcado pela tradição e pela situação originante da experiência. 


\section{0 ASPECTO LINGUÍSTICO DA HERMENÊUTICA FILOSÓFICA DA EDUCAÇÃO}

0 aspecto linguístico é a marca, o atributo fundamental do próprio pensamento e da própria relação e constituição do mundo. Porem, este atributo não pode ser entendido como fundamento, como um estado de coisas já presente no ser humano. No entanto, segundo o autor, "o que se dá na linguagem dá-se também no todo de nossa orientação vital: o fato de estarmos familiarizados com um mundo convencional pré-formado" (GADAMER, 2004, p. 236). No acontecer da linguagem, inicialmente presente na relação entre a criança e os outros seres já formados enquanto linguagem é que se dá a fundação do "logos linguístico". Pois, o pensamento não é anterior à imagem, como se esse se utilizasse de um instrumento (a linguagem) para manifestar ou dizer algo. Há, no entanto, uma inversão na forma de descrever como ocorre o pensamento e sua expressão ou manifestação, pois é a linguagem que mobiliza a criança a se constituir na relação de sentido e significado. Para o autor, "não é a história que nos pertence, mas somos nós que pertencemos a ela" (GADAMER, 2008, p. 367). Por que, pela linguagem, adquire-se uma posição, e essa posição lança o indivíduo em uma relação de diálogo com as coisas, com os fatos e com os temas. 0 pensamento, é assim como a compreensão, desde sempre já se estrutura com um dialogar com os próprios referenciais, ou com a situação na qual se encontra, de forma que algo se mostra no pensar e no compreender. Dizer que na compreensão, se dá um encontro é admitir a possibilidade do inesperado em que algo se apresenta e modifica toda forma de pensar. 0 diálogo tem a ver com uma postura de abertura frente às possibilidades do compreender, pois a vida diária, é repleta de momentos, de fatos e de encontros capazes de operar movimentos de ampliação da compreensão. " Por que a nossa compreensão não aprende num só golpe do pensar tudo o que sabe, precisa sacar de si cada vez o que pensa, pondo-o diante de si mesma como numa auto-expressão de seu íntimo" (GADAMER,2008, p. 546). Ele nos diz que, considerar a estrutura dialógica da razão, significa reconhece-la como uma imagem multifacetada da subjetividade.

Também aqui se torna claro que o homem que compreende não sabe e nem julga a partir de um simples estar postado frente ao outro sem ser afetado, mas a partir de uma pertença específica que o une com o outro, de modo que é afetado com ele e pensa com ele (GADAMER apud CRUZ, 2008, p. 425).

Por que há sempre uma relação de pertencimento à realidade, e a realidade não está dada no seu em si, mas se conjuga como realidade histórica justamente por estar em relação com um sujeito finito, com o outro. Pode-se entender porque Gadamer utiliza a expressão fusão de horizontes como um mover-se que não se abstrai totalmente da realidade e da história.

Em seu artigo sobre as contribuições da hermenêutica filosófica de H. G. Gadamer para a educação, o professor Daniel José Crocoli afirma que, adquirir um novo horizonte significa compreender de forma diferente, "[...] em um todo mais amplo e com critérios mais justos" (GADAMER apud CROCOLI, 2008, p. 403). Por que, para Gadamer, a compreensão se dá como fusão de horizontes do passado com o presente. Na fusão de horizontes, segundo Crocoli, está o sentido da fluidez, de finitude e o reconhecimento da originalidade na maneira de se compreender o mundo e a si mesmo. Compreender, segundo este autor,é recriar e aplicar um sentido em uma nova situação. Segundo ele, o velho se mantém, e a tradição torna a falar e a dizer algo, mas em uma situação nova que requer aplicação, tornando-se continuamente um ato criador. Em que "quase já não se pode contestar que o que caracteriza a relação do homem com o mundo, em oposição a todos os demais seres vivos, é a sua liberdade frente ao mundo circundante" (GADAMER apud CROCOLI, 2008, p. 537). Por que a subjetividade perde o seu lugar central, mas nem por isso se torna como que um fantoche da história e da tradição. Pelo contrário, ela adquire uma mobilidade maior em um espaço que pode ser criado e recriado.

Para Crocoli, em educação,se dirá que as elaborações de sentido adquirem diferentes configurações, tendo a pretensão de se manterem como verdadeiras em uma unidade capaz de orientar o próprio agir. 0 confronto, segundo ele, ou a pergunta, instaura a exigência de se justificar o modo como a realidade é interpretada. Reforça a idéia de que o outro elemento, que não necessariamente um outro eu, é indispensável para que se instaure o movimento e a mudança. Quando este outro elemento não se instaura, a educação, como ação e mudança, não ocorre e, consequentemente, há uma cristalização dos modos de conceber o mundo, a si mesmo e das formas de agir. Conceber a compreensão com o modo de ser característico do sujeito pode trazer alguns questionamentos sobre os efeitos que diferentes maneiras de compreender provocam nas relações intersubjetivas. Para ele, considerar que todos, de alguma forma, compreendem e desenvolvem ações influenciadas por esta maneira de compreender, compromete a instauração de uma justificativa para recusar determinada compreensão ou ação. 0 critério poderia estar na coerência das relações de sentido, associado ao limite de abrangência que essa compreensão ocupa. 
Outro critério cabível reconhece na própria situação concreta uma exigência. A capacidade de adaptar a compreensão ou o agir a esta exigência, mostra-se como uma aplicação equilibrada e passível de ser aceita intersubjetivamente. Segundo Crocoli,quando a compreensão é deslocada para a ação não responde às exigências da situação, significa que a ação não está adaptada. Assim, segundo ele, estão as ações de violência e de desrespeito, o que não significa que não haja uma compreensão, mas que essa compreensão se mantém deslocada do que a situação exige. Pois, muito se têm questionado sobre a instauração de limites em termos de educação. Para ele, o limite em si é agressivo e, por vezes, causa sofrimento, mas nem por isso é violento, de forma que o critério se encontra na situação. Para ele, Gadamer, através da ética aristotélica introduz no entendimento da compreensão o saber histórico de cada pessoa, que se aplica às situações concretas sempre como uma atualização. Gadamer encontra no modelo aristotélico uma forma de pensar a ética e a compreensão como um movimento que inclui a situação concreta e histórica. Cada indivíduo, na sua história e no seu tempo, se constrói e se educa. Para ele, o ser humano se situa para a hermenêutica filosófica como um animal hermenêutico, simbólico, linguístico e não simplesmente racional. Tanto o seu ser como o mundo estão em permanente mudança e passível de relações diferentes e originais.

\section{A DIMENSÃO CRIADORA DA EDUCAÇÃO E DA HERMENÊUTICA FILOSÓFICA}

Para Crocoli, Gadamer ao destacar que a educação é educar-se, ele está afirmando que o modo de ser do ser humano é essencialmente criador. Porque a criação, no sentido hermenêutico, não está ligada às coisas enquanto essência, mas enquanto linguagem. Compreende-se, consequentemente, o mundo e a si mesmo de um jeito único, que se desloca a cada nova experiência e a cada nova relação que se estabelece entre os elementos da tradição, ou do passado e as expectativas de sentido lançadas como possibilidades. "A experiência estética é uma possibilidade de ampliar a nossa compreensão sobre nós mesmos e sobre o mundo e aprimorar nossa capacidade de escolha" (HERMANN apud CROCOLI, 2010, p. 36). Pois, para esse autor, a educação fragilizada é a educação que não levou à uma ampliação das capacidades a das possibilidades de escolha do sujeito. Por que escolher também significa tomar decisões frente aos desafios da própria vida e da própria existência, que se estabelecem dentro da família, da escola ou da sociedade.

Crocoli nos sugere que, para o processo de educação, uma das questões centrais está ligada ao modo como se estrutura ou se configura uma determinada compreensão. Para ele, é possível admitir que as pessoas compreendam o seu entorno de alguma forma, mesmo que de formas diferentes. Por isso,

É importante o questionamento de como se processam essas compreensões, ou entender quais os elementos que estão em jogo e porque são estes e não outros, pois o sujeito, em um determinado momento, só é um sujeito que compreende desta ou daquela maneira. E para as situações em que não ocorre um movimento de ampliação ou de mudança dos referenciais ou dos esquemas de articulação dos diferentes preconceitos, pode-se pensar em situações de não educação, em que as possibilidades da compreensão se fecham em uma rigidez de aspectos, na própria pré-estrutura da compreensão. Entender esta situação de educação em que os referenciais se articulam de diferentes modos de compreensão passa pela aplicação do movimento dialógico para o próprio pensamento, ou seja, em um diálogo que se dá consigo mesmo "(CROCOLI, 2012, p. 8)".

Para esse autor, a dialética, no seu sentido próximo ao diálogo, ultrapassa a visão da dialética negativa e de oposição e se aproxima da idéia de reconhecimento. Para ele, o outro, o diferente, dialoga com o que está próximo do referencial compreensivo, e esse dialogar revela a dimensão de abertura frente a diferentes compreensões. Gadamer nos diz que, "o que perfaz um verdadeiro diálogo não é termos experimentado algo de novo, mas termos encontrado no outro algo que ainda não havíamos encontrado em nossa própria experiência de mundo" (GADAMER apud CROCOLI, 2004, p.247). Pois, no diálogo está contida a dimensão do compromisso em assumir o que de novo aparece na relação de aprendizagem. Só há diálogo quando o novo se mostra aos participantes do diálogo, de forma que o aspecto que deve permanecer aberto é o caminho que o próprio diálogo vai formando. Porque, "o diálogo possui, assim, uma grande proximidade com a amizade" (GADAMER apud CROCOLI, 2004, p. 247). Para o autor, quando se está diante de uma pessoa em que se confia, como um amigo, por exemplo, há uma predisposição para o outro e para o que ele diz. As opiniões contrárias, na relação de amizade, não impedem que haja diálogo, muito pelo contrário, se colocam em jogo a questão e o assunto. 0 que o outro diz torna-se parte de uma elaboração comum. Pensar a educação a partir da hermenêutica, faz da abertura, ou da predisposição uma exigência. 
Por isso, quando Gadamer fala da educação como educar-se, está aproximando o movimento interior do sujeito consigo mesmo e com a realidade intersubjetiva representada pela tradição e pelas circunstâncias que compõem a existência.

Crocoli destaca, que a vinculação existencial da compreensão, assim como o caráter efeitual da história, destacados pela hermenêutica como aspecto da realidade linguística do ser humano, atingem diretamente o entendimento sobre a educação. Na verdade, a educação se insere na existência como momentos de encontro com a realidade, com os outros e consigo mesmo no meio caracterizado como linguagem. Portanto, tudo na linguagem se movimenta como diálogo e como encontro capaz de afetar e, ao mesmo tempo, ser afetado, tendo o horizonte da tradição como limite.

Segundo Almeida, quando Gadamer fala de tradição não está se referindo a um sujeito coletivo, mas entende que "tradição é o nome comum para designar cada texto concreto (no sentido mais amplo da palavra texto, incluindo uma obra plástica, uma construção e até um processo natural)” (ALMEIDA apud CROCOLI, 2002, p. 219).

Portanto, quando há encontro e quando há educação, uma relação de sentido se instaura, se desvela e se abre. A cada nova experiência, novos conteúdos entram em jogo, abrindo novas possibilidades de relações, de perguntas e de respostas. Por que, na obra de Gadamer, educar é educar-se, está presente a dimensão criativa do processo educativo, de forma que é possível recriar a própria situação a partir de um horizonte mais amplo de visão. Nesta situação, o indivíduo atua como criador de novas alternativas de aprendizagem, distanciando-se do que está mais próximo, para relações mais adequadas com os limites da tradição. Pois aquele que a compreende realizou uma experiência de sentido, de forma que a realidade se mostra a partir de uma configuração determinada. Mesmo assim, não significa que esta maneira como a realidade se apresenta não possa ser reelaborada e compreendida de maneira diferente. Por isso, a compreensão, no sentido hermenêutico, está sempre posta em jogo, aberta a novas relações de sentidos.

Muitos dos conflitos envolvendo diferentes compreensões acabam não sendo produtivos e não se colocando como movimentos hermenêuticos, por não permitirem a abertura para que o outro, o diferente, possa se expressar. Este espaço em que o outro se apresenta é o espaço da pergunta. Pois, "perguntar, quer dizer colocar no objeto. A abertura daquilo sobre o que se pergunta consiste no fato de não possuir uma resposta fixa" (GADAMER apud CROCOLI, 2008, p. 474). Para Crocoli, talvez esta seja a justificativa para a expressão educar-se, de Gadamer, em que a mobilidade na educação se assemelha à mobilidade do diálogo e da conversão. Pois, onde não há abertura para o diálogo, não há conversão e movimento capaz de modificar as estruturas de sentido que orientam o agir humano.

Para Gadamer, a possibilidade de aproximação para com as coisas possui um caráter de conversão, ou seja, há sempre a participação de quem se põe a compreender e do que está diante da compreensão. Por isso, para ele, o movimento da compreensão, no sentido hermenêutico, é um movimento do risco e de exposição para o estranho, e até mesmo para posições contrárias. Por que estar aberto ao diálogo e à conversão é aceitar a possibilidade do novo e do diferente na constituição de sentido. Assim, para Gadamer, a pergunta é a condição hermenêutica da compreensão, a estrutura preconceitual exerce influência no espaço a ser ocupado pela pergunta. A questão principal, neste caso, é como interferir nesta estrutura que retroalimenta a não abertura para a pergunta. Ao se pensarnas intervenções concretizadas pelas estruturas sociais com o a família, a escola, etc., esse problema emerge como uma questão que envolve diferentes objetivos em educação.

\section{A EXPERIÊNCIA COMO REQUISITO INDISPENSÁVEL AO PROCESSO EDUCATIVO}

De certa maneira, a hermenêutica, assim como a educação, encontra uma base comum de sustentação: a experiência. Para esse autor, a particularidade como se efetiva a experiência na vida concreta, ou na existência, produzem atitudes que revelam um jeito de compreender as coisas, os fatos e a si mesmo. Mas a riqueza da experiência, segundo esse autor, não está propriamente no que é experimentado, mas no modo como o sentido é elaborado e reelaborado pela experiência. Pois, hoje, entra-se em contato, pela abrangência de informações disponíveis, com uma gama de informações ou contextos reveladores de experiências de outras pessoas. Os contextos histórico, social e econômico, por exemplo, podem ser destacados como realidade concreta de muitos outros indivíduos, porém, a maneira, o jeito como esses dados se articulam na compreensão e produzem interpretações diversas é essencialmente singular. 
Crocoli percebe que, tomar uma atitude (interpretar) já revela um jeito de compreender a realidade e a si mesmo. Pois, a educação se dá sempre que há um acontecimento hermenêutico de elaboração ou reelaboração de sentido. Por que " em todo pensamento e conhecimento já mostramos a parcialidade de nossa interpretação linguística do mundo. 0 acontecimento hermenêutico corresponde à finitude humana, mas essa finitude corresponde, por sua vez, uma infinitude de sentido[...]"(HERMANN apud CROCOLI, 2002, p.72). Por que a educação se dá como uma experiência de compreensão. Pois, estar aberto a esta infinitude de sentidos possíveis de serem elaborados pela experiência, mantém o indivíduo em um processode educação ao longo de toda a sua vida. Pois, é pela compreensão que o mundo se representa (apresenta) como linguagem, tendo nos preconceitos a base histórica da vida concreta e que permite a elaboração projetiva de um sentido.

\section{A LINGUAGEM COMO PARTE DA HERMENÊUTICA FILOSÓFICA PARA A EDUCAÇÃO}

A linguagem, como possibilitadora do diálogo, é vista por Gadamer como elemento de extrema importância, quando ele afirma que "a capacidade para o diálogo é um atributo natural do homem. Aristóteles definiu o homem como o ser que possui linguagem e linguagem apenas se dá no diálogo" (GADAMER, 2002, p. 243). 0 mesmo acrescenta ainda que, mesmo que a linguagem venha a ser submetida a regras e procedimentos, "sua vitalidade própria, seu amadurecimento e renovação, sua deterioração e depuramento até às elevadas formas estilísticas da arte literária, tudo isso vive do intercâmbio vivo entre os seus interlocutores" (Ibid, 2002, p. 243).

Considerando-se as palavras citadas, pode-se compreender que a concepção gadameriana de linguagem se desenvolve entre os seres humanos de forma viva. Os interlocutores comunicam-se pautados por interesses de entendimento. Também se pode notar que o autor busca respaldo para a sua concepção, no pensamento aristotélico e conclui que a capacidade para o diálogo é uma característica que define o ser humano. No campo educacional é importante esse ponto, pois a aprendizagem que o aluno desenvolve pode ser despertada pelas influências do seu (s) professor (es). Se o professor, como representante da tradição, detém um bom conhecimento e metodologias adequadas, a tendência é que o aluno assimile esses conhecimentos quando os horizontes dos dois estabelecerem uma relação de fusão. E o contrário também pode ser verdadeiro. Portanto, é importante se considerar esses termos na relação dialógica. Pois, o aprendizado ou o conhecimento ocorre quando há fusão de horizontes, entre o horizonte do professor e o horizonte do aluno. Segundo Gadamer, é a mediação entre esses dois horizontes que faz surgir o entendimento e a compreensão, elementos fundamentais no processo de ensino-aprendizagem.

Essa fusão de horizontes pode ser compreendida com fusões de concepções. Do confronto entre professor e aluno, que são sempre sujeitos particulares e portadores de diferentes alteridades, já que não há horizontes iguais, geram-se, por meio do diálogo, a compreensão, o conhecimento e a aprendizagem. Nesse sentido, a relação entre o horizonte do professor e o do aluno é estabelecida por meio da linguagem. Assim, a linguagem se dá no diálogo entre as partes propícias de fusão e assume a função de integrar os horizontes, condicionando os pensamentos e a linguagem conforme a tradição para serem coerentes com a sociedade. Na concepção gadameriana, o diálogo permite desenvolver as etapas de aprendizado que facilitam a inserção e o convívio do ser humano na sociedade, pois ele perpassa toda a realidade dosprocessos de ensino e de aprendizagem.

Segundo Leonir Dal Mago, nesse contexto, compreende-se que a hermenêutica filosófica surge com um grande potencial de descoberta e de abertura intelectual investigando os sentidos; é compreensiva e permite ao ser humano chegar aos objetos por meio da linguagem. Para esse autor, no exercício do diálogo o ser humano revela-se possuidor de um grande potencial de aceitação da alteridade do outro, e essa aceitação é fundamental para ele se inserir e viver em sociedade, pois para viver em sociedade é preciso reconhecer no outro um outro eu, não um objeto. Por isso, a hermenêutica filosófica prima, segundo ele, pela busca de sentidos. Porque o sentido é a base para os processos de conhecimento que se desenvolvem pela linguagem; o sentido e a linguagem possibilita aos seres humanos a compreensão.

Nesse panorama, o próprio sujeito se educa com o outro, através do diálogo. Dessa forma, o diálogo não é um procedimento metodológico, mas se constitui na força do próprio educar, que é educar-se no sentido de uma constante confrontação do sujeito consigo mesmo, com suas opiniões e crenças, pela condição interrogativa na qual ele vive. Para Mago, é por meio do diálogo que surge a experiência do conhecer, e isso representa uma nova concepção, passando pela possibilidade de conhecer solitariamente para a possibilidade de conhecer pela conversão com os outros sujeitos. Ainda de acordo com esse autor, considerando essa mudança, Gadamer \assinala que o processo educativo se dá pela interação, mediada pela linguagem, com os outros indivíduos. 
E isso adquire importância fundamental porque "conceitos fundamentais como o de círculo hermenêutico, mostram que em todos os nossos procedimentos racionais projetamos pontos de vistas, esquemas interpretativos, que não se confundem com novos horizontes de sentido" (HERMANN apud MAGO, 2002, p. 101).

\section{CONSIDERAÇÕES FINAIS}

Portanto, assumir a estratégia reflexiva, respeitando e valorizando a participação do outro na elaboração dos conhecimentos, resulta que educar e compreender se tornam, assim, uma aventura na qual o sujeito e os sentidos do mundo se constituem mutuamente na dialética da compreensão e da interpretação. Porque os sentidos produzidos por meio da linguagem são condições que possibilitam ao ser humano agir coerentemente no mundo. Dessa forma, compreende-se que educar pela via do diálogo, exige que o educador seja um intérprete: intérprete de um contexto no qual os seus alunos se apresentam com alteridades, exigindo dele tolerância às diferenças e uma postura de diálogo. Tornando-se fundamental estar sempre disposto a buscar espaços para o diálogo, para o auto esclarecimento e para a produção de novos conhecimentos. Portanto, a questão defendida por Gadamer, não consiste em ditar receitas prontas sobre aquilo que se deve fazer, mas sim, em formar capacidades de diálogo e de escuta, as quais são posturas que vão conduzir os envolvidos no processo educativo a fazerem suas experiências compreensivas. Dessa forma, cada sujeito desenvolve o potencial que carrega consigo em sintonia com os demais sujeitos que o rodeiam.

\section{REFERÊNCIAS}

[1] CROCOLI, Daniel José. Contribuições da Hermenêutica Filosófica de Hans Georg Gadamer para a Educação. IX ANPED SUL 2012. Seminário de Pesquisa em Educação da Região Sul.

[2] CRUZ, Artigo, José Barros. Hermenêutica e educação: o sentido gadameriano de diálogo ressignificando as relações pedagógicas. Artigo. Revista Espaço Acadêmico - no 112 - setembro de 2010.

[3] GADAMER, Hans Georg. Verdade e método I: traços fundamentais de uma hermenêutica filosófica. Tradução Flávio P. Meurer. Petrópolis, RJ: Vozes, 1997.

[4] MAGO, Leonir Dal. Gadamer: hermenêutica filosófica e educação. Dissertação de mestrado. Universidade de Passo Fundo - RS, 2009. P. 96 - 103. 


\section{Capítulo 3}

A filosofia para os gigantes da física: O perigo da ausência do pensamento crítico

\section{Rafael Ferreira Fernandes}

Júlio Pereira da Silva

Roberto Roque Antunes Oliveira

Resumo: Esta pesquisa acadêmica, de cunho bibliográfico, apresenta algumas ideias filosóficas, ressaltando as concepções advindas do pensador Immanuel Kant, segundo Vitte (2005), relacionando-as a física natural e a noção sistemática do pensamento crítico com a filosofia pura. Postergando o interesse em justificar o escrito, adquirimos a segurança em apresentar-lhes a tônica desta obra, segundo uma percepção a nível de graduação, por não haver penhor para trivializar e universalizar. Assim, o presente artigo tem como intento, provocar uma reflexão sobre a ausência do pensamento crítico na filosofia dos físicos, considerando o conhecimento das primeiras causas no que tange o acaso do pensamento. A filosofia numa perspectiva amplamente aceita, é o amor pelo saber; é o pensamento crítico cognitivo e consciente. Para alguns físicos tão somente basta a formalidade matemática da ciência como efeito do conhecimento, posicionamento no qual, levanta questionamentos que podem ser discursivos. Finalmente, admitindo que existe, portanto, uma distinção implícita nos tipos de raciocínios dos genuínos filósofos e dos filósofos físicos, é importante destacar que o absentismo analítico no pensamento de alguns cientistas é por vezes inconsciente ou imprudente, pois em muitos casos pode dificultar o caminho para o êxito.

Palavras-chave: Filosofia dos Físicos. Filosofia dos Filósofos. Pensamento Crítico. Teoria do Conhecimento. 


\section{INTRODUÇÃO}

Não existe uma definição acabada sobre o quê é, ou o quê há de ser a filosofia, mas é cógnito, que dela advêm o escápulo da racionalidade, na qual, por conveniência e sensatez, pode ser encarada e não limitante a tal noção, como: 0 apreço perene pelo saber como se soube, o zelo pela sabedoria, a obstinação para desvendar a essência de tudo que perfaz, possui função sistemática de silogismo, logo, é legítimo considerá-la como a ciência primeira.

A fundamentação teórica desta obra é complementar para a aplicação do saber. Destarte, julga-se aqui, paradoxal e sandio a inexistência do caráter filosófico e crítico do pensamento entre cientistas/físicos. Isto é, adimitimos que há um leve distanciamento na maneira de se pensar e de produzir sapiência entre filosofos profissionais e cientistas naturais ${ }^{1}$, além do mais, negar-se conhecer a razão dos feitos e efeitos do produto da ciência, ou fazer inflexões ao ato primeiro de investigar e questionar as coisas e o âmago peculiar, pode dificultar a chegada ao conhecimento, a uma descoberta, ou até mesmo, a uma interpretação válida e fortemente ideada sobre o rigor lógico.

Por esta leva, o físico e filosofo Mario Bunge (apud DAHMEN, 2006) abona que todo cientista se nutre de posturas filosóficas, embora frequentemente nem todos o façam de maneira totalmente consciente. Assim, é de inteiro tato, ruminar antes, durante e depois de cada realização. Essa referência provoca reflexões inerentes à complexidade da afirmação do autor supracitado, na qual, por simplicidade denotamos a importância de se resgatar a conduta consciente, crítica e filosófica legada dos antigos.

0 artigo é um ensaio que perpassa por um caracter epistemologico da faculdade da razão entre os grandes físicos, com a finalidade de pleitear a respeito da intelecção dos filósofos os quais não são físicos e, ao mesmo tempo, mostrar de forma lacônica uma ligeira diferença entre os dois tipos de argúcia que, em epítome, não se opõem completamente.

Como preâmbulo deste, sinalizamos quem são os gigantes da física, e o móbil de tal títulação. Por um lado, inferi-se rótulo, conforme cada contribuição e realização pessoal do cientista ao longo da história, e por outro, nos embasamos exclusivamente segundo a obra de Richard P. Brennan, titulada como: "Gigantes da Física: Uma história da física moderna através de oito biografias," publicada no ano de 2000 , ao qual, faz mensão a mentes que passaram e revolucionaram o pensamento científico moderno. É importante sublinhar que não é feito um apanhado detalhado dos nomes e realizações que marcaram a ciência/física.

Na tônica seguinte, ilustra-se, respectivamente, como é delegada a filosofia para os físicos em paralelo com a filosofia dos filósofos, mostrando que, de fato, existe uma maneira de fílosofar particular presente para os dois casos, de tal modo que, ligeiramente, as diferem na proficuidade e exercício do saber.

Adiante, versa-se sobre o perigo da ausência do pensamento crítico, que por sua vez, trata da predisposição que alguns cientistas assenhoreiam à pura normatização moderna ao desconsiderar o espólio da filosofia, ou seja, o rito de interrogar-se sempre sobre o que é feito, e se faz, ou mesmo, o que se pode fazer com o que foi feito.

No ultimo mote, segue o tópico: "Do Pensamento Crítico ao Êxito" que trata de arrazoar sobre a conduta crítica que conscientimente deve estabilizar-se sobre o pensamento de quem desenvolve ciência. Neste interim, se faz ressalva a importância que um erro pode ter no desdenhar de alguma atividade prática ou mental, e assim, consequenciar em realização e, insocronicamente, no êxito. Após, é tecida algumas considerações e reflexões advindas desta sondagem bibliográfica, compondo a parte denominada de, conclusão.

\section{ASPECTOS METODOLOGICOS DE ESTUDO}

Esta produção acadêmica dentro da abordagem de pesquisa qualitativa, caracteriza-se como pesquisa bibliográfica. Conforme GIL, (2010), p. 29 e COSTA, (2011) que corroboram em entendimento, afirmam que a pesquisa bibliográfica é elaborada com base em material diponível ao búblico. Por sua vez, esta modalidade de pesquisa inclui livros, revistas, jornais, teses, dissertações e escritos de anais de eventos científicos.

\footnotetext{
${ }^{1} \mathrm{O}$ termo "cientistas naturais," é utilizado nesta obra a fim de fazer referência aquele que lida com fenômenos da natureza - um físico profissional.
} 
A partir das leituras feitas em livros, sites, artigos estudados nos componentes curriculares durante a graduação e das discussões realizadas nas aulas do Ensino Superior, que emergiu a curiosidade de produzir e aprofundar a leitura sobre o tema.

De acordo com GIL (2010), este tipo de pesquisa possui algumas vantagens: permite ao investigador a cobertura de uma gama de fenômenos muito mais ampla do que aquela que poderia pesquisar diretamente; e é indispensável nos estudos históricos.

Ainda conforme o mesmo autor:

\begin{abstract}
Em algumas áreas do conhecimento a maioria das pesquisas é realizada com base principalmente em material obtidos em fontes bibliográficas. É o caso, por exemplo, das pesquisas do campo do Direto, da Filosofia e da Literatura. Também são elaboradas principalmente bom base em material já publicado, as pesquisas referentes ao pensamento de determinado autor as que se propõem posições diversas em relação a determinados assuntos (GIL, 2010, p. 30).
\end{abstract}

Sendo assim, o estudo em questão, confirma-se como uma pesquisa bibliográfica, por se embasar por material já disponível, ao qual, vêm mostrar a relação do pensamento filosófico entre um físico e um filosofo, denunciando, a ausência do pensamento crítico dentre alguns físicos. As reflexões desta obra ficarão inacabadas, por ser um ensaio teorético singelo sobre o tema.

\title{
3. GIGANTES DA FÍSICA: ALGUNS PENSADORES
}

Em toda história da ciência, nos deparamos com referenciados, conhecidos, e reconhecidos cientistas que contribuíram para o desenvolvimento da ciência e, especialmente da Física. Todos os cientistas mencionados adiante, deixaram sua marca registrada na história da física, mudaram paradígmas e expandiram o conhecimento empírico para encontrar sentido naquilo que procurara. Logo, nenhum fenômeno sobre o universo e seus componentes lhes foram alheios.

Acreditamos que cada qual, conduziram os conhecimentos a priori daquele que já falava Kant (1781), traduzido por PINTO e MORUJÃO (2001) de maneira objetiva, mas ainda exânime da essência. 0 conhecimento adiquirido ao longo da história, ou mesmo, os fundamentos a priori percebidos, serviram como base para interpretação da natureza, suas manifestações e mudanças constantes que se apropriaram muitos físicos, mesmo alguns fazendo uso inconsciente de sua origem filosófica pura.

Portanto, foi a partir das primeiras progressões das faculdades suficientes da razão, que o objetivismo foi ganhando significado, assim como a prática dos ciêntistas tornaram-se conhecimento concreto de via privilegiada.

A física talvez seja a ciência mais preocupada com os fins da linguagem matemática e os métodos científicos até os dias de hoje, mas afinal, quem são os gigantes da física, que por sua vez, fizeram da física o que ela é? Os nomes que escolhemos citar, baseiam-se quase que exclusivamente na obra de BRENNAN (2000).

É importante fazer um breve resgate na história. A muito tempo, muitos homens pensantes e curiosos, se esforçavam para entender o que ocorria ao seu entorno, referentes a mudanças de ordem natural, ou seja, a variação de clima e tempo, além de muitos acontecimentos que não fugiram aos olhos.

Antes dos gregos antigos, em algumas regiões, como China, Egito e na parte da grande Mesopotâmia, pessoas observavam a natureza de forma intuitiva, e assim, tentavam compreender as leis naturais ao seu redor. Conforme cita BRENNAN (2000) os árabes, por exemplo, deram à civilização seu atual sistema de numeração. As célebres pirâmides, cuja construção demandou um incrível conhecimento de matemática, já eram bastante antigas quando os gregos começaram a discutir filosofia e ciência. (BRENNAN 2000, p.12).

É mister que antes do próprio Sir Isaac Newton, já havia construção de conhecimento, uma física primitiva, isto é, os primeiros passos da física iniciados por homens esforçados e curiosos, que nos deixaram uma herança importante. A princípio não havia separação daquele pensante, amante do saber, com o que nós conhecemos hoje como um cientista profissional. 
A medida que algumas descrições teoréticas sobre os fenômenos da natureza eram criadas, é possível que muitos tenham sidos esquecidos da lista dos grandes e gigantes aqui referenciados e até mesmo na própria história. No entanto, aos que temos de registros, na obra de BRENNAN (2000), historiadores já consideravam, Tales de Mileto (640-546? a.C.) como o primeiro filósofo e o primeiro cientista, a posteriori, sucedido por Pitágoras (c.582-c.500 a.C.) e seus seguidores, que descobriram que o mundo real pode ser compreendido em termos de uma linguagem matemática.

Contudo, a evolução é progressiva na grecia com as obras de Euclides, Aristarco, Arquimedes, Eratóstenes, e diversos. A exemplo, Euclides (c.300 a.C.), é um nome conhecido por muitos, quase como sinônimo de geometria, e o mesmo escreveu um manual que foi padrão de literatura e conhecimento durante séculos, chamado 'Stoicheía-Elementos'

Adiante, podemos citar ainda, Aristarco de Samos (c.260 a.C.), que calculou o tamanho real da Lua ao observar o comprimento da sombra projetada pela Terra durante um eclipse lunar. (BRENNAN 2000, p.13). Entre os gregos temos, em seguida, Arquimedes (287?-212 a.C.), reputado o mais eminente cientista e matemático da Antiguidade. Foi considerado o primeiro cientista e engenheiro por realizar experiências práticas dos conhecimentos teóricos. Assim, Arquimedes formulou e provou o princípio da alavanca (BRENNAN 2000).

Por conseguinte, temos, ainda conforme BRENNAN (2000), Nicolau Copérnico, Johannes Kepler e Galileu Galilei, logo, passaram-se apróximadamente 1.700 anos, séculos durante os quais as teorias de Cláudio Ptolomeu (127-151 d.C.) dominaram o mundo pensante.

Destarte, em 1676, um modesto físico, chamado Sir Isaac Newton, escreveu numa carta a Robert Hooke, colega cientista e rival de longa data: "Se enxerguei mais longe que outros homens foi porque me ergui em ombros de gigantes" (BRENNAN, 2000, p.13). Por esse condão, o físico Steven Weinberg exprime uma opinião sobre esse gênio da ciência-física: "É com Newton que o sonho moderno de uma teoria final da física realmente começa." (BRENNAN 2000, p.9)

Sir Isaac Newton é um dos grandes cientistas, que formulou e expandiu a teoria da gravidade para corpos celestes. Sua teoria se tornou universal. Newton estabeleceu três leis fundamentais para a Física Clássica. Seus estudos fundamentais, tornaram-se inspiração para o início de uma física moderna, repleta de novas ressignificações, principalmente relativos a estudos que competem a física.

Passaram-se muito tempo, e a física tinha uma boa estrutura explicativa, já se tinha bons métodos científicos, no entanto, parecia que mais nada havia para se descobrir, e os homens-grandes, deixara um legado aparentemente sem margem para o progresso. Os físicos pareciam ter dominado de uma vez por todas a natureza pela compreensão.

No entanto, em seguida, raia um nome marcante, Albert Einstein (1879-1955), que foi sucessor de Newton. Desenvolveu muitas teorias, fez ciência e filosofia livre. Em seu percurso, Einstein introduz o conceito de que a luz é uma distribuição de pequenos pacotes de energia (quantum) que ele chama de Fótons, e ainda produz uma implicação ao nível microscópico chamado de Efeito Fotoelétrico. Uma descrição diferente dos resultados experimentais e da matemática de Maxwell. Esse trabalho lhes rendeu o prêmio Nobel de Física em 1921. No modelo quântico previu que luz de mais alta frequência produziria elétrons de mais alta energia e que eles seriam independentes da intensidade (RODRIGUES, 2017).

Sua Máxima, foi a teoria da relatividade, que foi dividida em duas obras, uma nomeada de teoria da relatividade restrita/especial, que deslinda a física do movimento na ausência de campos gravitacionais, e a teoria da relatividade geral, composta de séries de hipóteses de forma generalizada, que engloba tanto a relatividade restrita, como a lei da gravitação universal de Newton, e assim, fornece uma descrição diferenciada e unificada do que se entende por gravidade, agora, como uma propriedade geométrica/matemática dos entes da física clássica (espaço e tempo).

Houve, neste período uma nova mudança de paradigmas com a teoria de Einstein, e assim, uma nova configuração de pensamento criada dentro da comunidade científica, pois, passa-se a ter uma física não newtoniana-clássica. Portanto, Einstein, explicou de fato como a gravidade funciona, o tempo e o espaço, passam a ser um único ente. Após a física não newtoniana, uma nova maneira de interpretar o mundo começa a ser desenvolvida.

Os estudos sobre a luz, nunca foram encerrados, junto a Einstein, e outros, Max Plank, ao estudar o comportamento das faixas negras (radiação de corpo negro) no espectro eletromagnético, dá início a uma nova concepção de ciência, ou melhor, ou nova física. Na tentativa de se entender a radiação de corpo negro, e os fundamentos da matéria ordinária, respectivamente o que ocorre com as órbitas estáveis dos 
elétrons, que inicia-se uma física numa escala subatómica, até contraintuitiva, chamada de mecânica quântica.

Os alicerces da física quântica foram estabelecidos durante a primeira metade do século XX por nomes, não limitantes a estes: Albert Einstein, Werner Heisenberg, Max Planck, Louis de Broglie, Niels Bohr, Erwin Schrödinger, Max Born, John von Neumann, Paul Dirac, Wolfgang Pauli, Richard Feynman. Sem dúvidas, todos deixaram grandes contribuições para a física, que ainda vem sofrendo mudanças e evoluindo.

Destarte, para fechamento deste subtópico, referimo-nos aos grandes-gigantes da física, aqueles notáveis, reconhecidos, ousados, pensantes e ativos no campo do saber. Todos os nomes supramencionados, estão dentre os mais conhecidos da física por acadêmicos e entusiastas.

\title{
4. A FILOSOFIA DOS FÍSICOS E A FILOSOFIA DOS FILÓSOFOS
}

Assumimos que existe duas maneiras de reflexionar no campo do saber cintífico-filosófico. Uma particular dos filosofos profissionais, e uma dos cientistas naturais. Não é banal delinear esse paralelo, quando de veras trata-se de uma separação técnica entre os termos, que se deu como uma causa histórica, que separa a física da filosofia, que por simplicidade, também o filosofo de um físico.

Para falarmos a respeito da filosofia de quaisquer que seja os pensadores, é necessário que entendamos a respeito do que é filosofia, segundo alguns autores.

\begin{abstract}
0 ponto de partida dessa determinação deve ser, para nada perder em objetividade, a consideração e exame do próprio conteúdo e desenvolvimento daquilo que se tem por pesquisa filosófica e do Conhecimento em geral. Mais comumente a Filosofia é tida como uma complementação da Ciência e da elaboração cognitiva em generalizado; como seu coroamento e síntese (PRADO, 1987, p. 02).
\end{abstract}

A filosofia de modo geral esteia-se como uma procura incessante em compreender a própria natureza, como também a natureza das coisas; a filosofia seria isso mesmo: "uma especulação infinita e desregrada em torno de qualquer assunto ou questão, ao sabor de cada autor, de suas preferências e mesmo de seus humores" (PRADO, 1987).

Os fundamentos de existência, partindo de perguntas com respostas muitas vezes improváveis para o momento, como por exemplo; Se Deus criou os céus e a terra, e tudo que neles há, então, quem gerou Deus? Quem, o quê, quantos, e como seria essa entidade? Essas são perguntas de soluções improváveis de ser objetivadas. Todavia, se tem algumas não menos importante, complexas, e comuns, como: Quem somos? Para onde vamos? 0 que é a vida? 0 que é a morte? 0 que é o bem e o mal? Dentre diversas. Nenhuma dessas indagações são triviais, mas são elas que movem o mundo até hoje. Se não fosse os primeiros quetionamentos filosóficos, a ciência, não teria, e nem tão pouco seria.

É redundantemente crucial saber que, por vezes é necessário momentos de solidão, para desenvolver o pensamento intelectual, crítico, uma vez que, a análise do mundo real/conhecido sendo encarado diretamente no campo das ideias, nos leva para uma dimenção imaginária e infinita de especulação, racionalidade e subjetividade, isso que dá identidade aquele bom pensador, e desenvolvedor de ciências.

É a partir do mundo das ideias e da consciência humana, que as coisas são tidas como são e, não ao contrário. Portanto, o interesse em descobrir ou investigar minunciosamente como aquilo imaginado pode tornar-se real, prático ou objetivo; é realizar Filosofia.

Para Platão "a filosofia sumariza a razão, esse mundo das ideias não é senão o pensamento a função pensante e a atividade racional do homem" (PRAD0, 1987, p.18). Como atividade racional, não somente importa a reflexão solitária, é relevante o envolvimento social com os nossos pares, para desenvolver discussões saudáveis, pois somos o que somos com a presença do outro, e de fato, as opiniões adversas ajudam na autoreflexão.

Outrossim, fazem filosófia livre dentro dos seus campos de estudo, muitas vezes incosncientes do que estão realizando, ou mesmo, ficam subjugados aos métodos, e quando se tem o resultado experimental de suas ideias parciais, se dão por satisfeitos, sem se interessar pelas implicações daquela busca. É a partir deste ponto, que podemos citar uma pequena destinção de raciocínios entre os filosofos e alguns físicos. 
Física é a ciência que trata da matéria, da energia, do movimento e da força, tudo desde a imensidão do cosmo até a menor partícula indivisível da natureza (BRENNAN 2003, p.09). Por esta senda, os físicos costumam conceituar a força, velocidade, tempo, e o espaço, mas por incrível que pareça, a formação de tais conceitos não se encontram na física, nem na matemática, mas numa filosófia pura desenvolvida até então.

Portanto, tanto a Física quanto a Filosofia nesse ponto de interesse estão expressamente entrelaçados. 0 que separa um legitimo filosofo de um físico profissional, é a técnica, a cosnciência da realização e maneira de olhar para as problemáticas. Assim, podemos destacar que "o físico Einstein não era um filosofo profissional, na concepção que atribuímos ao termo, da mesma forma que Kant resguardado ao contexto não era um físico" (DAHMEN, 2006).

Para os cientistas dessa ciência em particular, ou seja, para os físicos, os filósofos são tão somente pensadores que se dão ao trabalho de pensar. Para os filósofos, os físicos não pensam de maneira eficaz ou suficiente, realizam suas obras sem compreender completamente aquilo que mesmo faz/cria. Conforme Hans Reichenbch a filosofia de Einstein era consequência de seu trabalho cientifico, e não ao contrário.

Para os físicos, a filosofia tem fundamento ou importância até chegar numa ideia inicial para que se possa começar um trabalho e terminar o mesmo. Assim, o fruto da filosofia pouco importará se as ideias não forem comprovadas. Mas porventura a hipótese que não admite teste, esta não poderá ser considerada ciência? Para muitos, não. Mas a evolução da ciência se dar por meio do pensamento crítico- consciente, que muitas vezes estão a frente do seu tempo e da comprovação por métodos comuns.

Na Física moderna de Einstein, para formular a teoria da relatividade, foi necessário a experiência de trabalho e a apropriação filosófica para perceber que o tempo e espaço não são grandezas absolutas.

Segundo DAHMEN (2006), Albert Einstein tinha um gosto pela fílosofia não apenas por suas extensas leituras, mas também pelo convívio que tinha com grandes nomes da filosofia da ciência, como Ernst Mach, Moritz Schlick, Hans Reichenbach e Ernst Cassirer. Dentre estes citados, o postremo era um grande propagador das ideias de Kant.

De forma símil, Sir Isaac Newton é descrito como alguém que no ato de inspiração súbita, desenvolveu um trabalho completo (SILVA, 2006). Nas conclusões de DOBBS apud SILVA (2006), Deus aparece para Newton como a causa da gravidade, explicando a interação entre corpos. Ao fazer essa atribuição, ele poderia ser chamado de louco por acadêmicos imparciais, mas isso são, de fato, afirmações de competência filosófica.

As argúcias de um autêntico filosofo é fertil e passiva de flexibilidade. A filosofia de um físico, por outro lado, tende a ser falsamente livre, por muitas vezes basear-se em indiossincrasias derivativas de seus feitos, ou mesmo pragmatizadas na formalidade. Assim, é seguro inferir que cada físico dentro de sua área de estudo fazem uso de uma filosofia particular, muitas vezes resultado de seu trabalho, de suas experiências profissionais, e que as grandes realizações da ciência dependeram, ou mesmo contingenciaram com a filosofia legada dos antigos.

\section{O PERIGO DA AUSÊNCIA DO PENSAMENTO CRÍTICO}

Mais do que o "conhecer", é necessário entendermos a origem e a abrangência deste nosso conhecimento (DAHMEN, 2006). Portanto, negar saber ou refletir sobre o que já se conhece, é caminhar às cegas sobre uma corda bamba sem uma razão para viver.

Neste ponto de determinação, a atuação da mente é estritamente significante. Exercer o que chamamos de pensamento crítico, significa a cima de tudo ser flexível a maneira de se perceber, de analisar, de pensar, e fazer uso da razão pura, considerando a possibilidade de erro no processo, além de refletir sobre as consequências de qualquer descoberta. Já que falamos em ciência, vamos considerar aqui apenas uma, a física.

Assim, é interessante sempre considerar a dimensão de uma descoberta mesmo antes dela ocorrer. Afinal, como ja dizia Karl Marx, "se a realidade fosse transparente não teria sido necessária a ciência" (PASSOS, 2014, p. 09).

Em sintese, trataremos dessa função da mente por um único ponto de vista para este tópico. todavia, vamos levar em consideração aquela maneira racional que Kant considerava em suas obras mais famosas, como a crítica da razão pura e a metafísica dos costumes, que trata daquele conhecimento a priori do sujeito e do estudo sobre a constituição do pensamento que agrega fundamento para toda e qualquer 
ciência.

Segundo Antonio Carlos Vitte, o gênese da geografia da física moderna, está associado à filosofia kantiana que permite a faculdade da razão organizar a natureza, pela sua flexibilidade, isso Kant descreve em sua terceira crítica (VITTE, 2005, p.01).

As obras de Emmanuel Kant fazem alusão ao conhecimento a priori, considerando a metafísica como significante e suficiente para explicar a natureza das coisas.

A metafísica de Kant explica por exemplo, o problema da dinâmica dos corpos que tendiam para o estado inercial e resolve os questionamentos de Leibniz, não graças as concepções Newtonianas, mas graças a filosofia Kantiana. (VITTE, 2005).

Newton era um físico renomado e contudo precisou do pensar crítico para estabelecer por exemplos as suas leis (VITTE, 2005), mas é notório que a sua filosofia própria não seria suficiente e tinha que se apropriar de novos saberes críticos, saberes estes, filosóficos já existentes, portanto a filosofia do filosofo na sua concepção geral completa o físico.

É necessário esclarecer o conceito de metafísica, que, segundo Nicola Abbagnano (2000), é a ciência primeira que tem por objeto todas as outras ciências e tem como princípio ser condição de validade de todas as outras ciências. Sendo que para Aristóteles (384-322 AC) a metafísica é a ciência que estuda todas as causas ou todos os princípios primeiros ou todas as substâncias ou as substâncias e seus atributos. A metafísica, segundo Aristóteles, é a ciência que forneceria a todas as outras o fundamento comum, ou seja, o objeto a que todas elas se referem e os princípios das quais todas dependem (VITTE 2005, p.03).

0 acaso do pensamento se encontra diretamente ligado a metafísica por ser o conhecimento primeiro, e é para muitos autores o pensamento que valida à ciência. Nossas ideias não são reflexo do real, mas traduções dele (MORIN 2013, p.145).

Na Crítica da Razão Pura (1989), Kant descreve a metafísica como sendo a crítica da faculdade da razão com respeito a todo conhecimento a priori e como sendo a ligação sistemática de todo o conhecimento filosófico derivado da faculdade de pensamento depurado (VITTE 2005, p.03).

Contudo, não se faz ciência inocentemente, não é notório para um físico um fenômeno se não houver sensibilidade, se não houver razão, pois justamente trata-se de aclarar aquilo que era intransponível.

O pensar na física, ou em qualquer ciência, sempre foi e sempre será de natureza filosófica, pois dela mesma a razão e o objetivismo raia. Cabe aqui, fazer uma pequena distinção. Na Física, para citar apenas um exemplo, a nostalgia pelo método, pela matemática, pelo formalismo tem ganhado crédito não a toa, mas que restringe e apresiona o cientista na sua cadeia de tecnicismo. 0 trabalho do profissional em ciência deixa pouco espaço para questões de cunho mais epistemológico (DAHMEN, 2006).

Pode-se por este fato, dificultar ou diminuir a amplitude com que uma realização, ou descoberta pode ter, afinal, de que serve a engenharia, a física, a matemática, a biologia, a química, ou qualquer outro ramo, se não oferecer uma resposta passiva ao progresso, boa, e prática para todos? 0 sonho que se sonha só, pode ser pura ilusão, mas o sonho que se sonha junto é indicativo de solução (PASSOS, 2014, p. 04).

Digamos de forma grosseira, para finalidade deste tópico, que é necessário pensar muitas vezes, exterior ao padrão convecional. Isto é, pensar críticamente, exige passar não somente pela racionalidade, mas também pela criatividade.

\section{DO PENSAMENTO CRÍTICO AO ÊXITO}

A evolução da ciência dá-se pelo pensamento crítico aplicado factualmente. Para Kant a origem do conhecimento é a experiência (no fenômeno), mas suas organizações passam por estruturas a priori em nós (DAHMEN, 2006).

O conhecimento passando primeiro por nós tornamos a ciência vulnerável ao erro, relativizando o que entendemos por verdade absoluta. Então, se a ciência apresenta erros, qual seria o caminho para o êxito? O fato extraordinário é que a vida comporta também processos de utilização do erro, não só para corrigi- 
los, mas também para fornecer o aparecimento da diversidade e a possibilidade de evolução (MORIN 2013, p. 143-144).

Um caminho que pode ser considerado paradoxal, é o caminho da racionalidade após um "Erro" cometido. Digamos mais, em muitas ocorrências na prática da ciência, foram erros de experimentos, que levaram a posteriori a assertividade. Segundo MORIN (2013) a verdade emerge primeiro sob uma forma absoluta, mas sobretudo a forma absoluta das ideias dogmáticas.

É intressante levar em consideração, que um caminho eficiente para uma grande descoberta, é considerar o que já foi falado anteriormente, que é exercer o pensamento na dimensão mais profunda que podemos chegar, que é envolver-se sobre para além da racionalidade, também a criatividade humana.

A respeito da questão do 'erro', podemos classificar em dois tipos: primeiro, aquele comum que acontece num processo rotineiro de racionalização ou organização das ideias em busca de uma resposta, ou seja, um erro que o cientista pode cometer na práxis de sua profissão, num experimento, erros de cálculos, e outros. Estes supramencionados, podem oferecer novas maneiras de ponderamentos que permite $o$ cientista evoluir. No entanto, o segundo, é aquele que MORIN (2013), fala. Ele assegura que fetivamente a ideia de verdade absoluta na ciência é a maior fonte de erro. Neste caso, é factualemente negativo, e prende o cientista sobre a ilusão de que sua ciência é a expressão absoluta da verdade.

É necessário o exâme sobre tais classificações. Sobretudo, Marx, certa ocasião, ironicamente dizia que, a gente joga "a filosofia pela porta, e ela entra pela janela". (PASSOS 2014, P.09). É mister, que não podemos fazer estapafúrdios consciente de pensamentos aleatórios prevendo suas consequências errantes, mas demasiadamente não estamos desintegrado do pensar, pois quem pensa, pensa até por involuntariedade, a medida que a razão organiza as ideias, faz-se filosofia em suas práticas, seus ditos, sua cultura, história, na condução da esperança livre, na descrição e interpretação do real.

Ninguém vive sem filosofia. Menos ainda educadores. Movidos a projetos, sonhos, opiniões, paixões, crenças, ciências, símbolos, percepções, racionalidades e irracionalidades. (PASSOS, 2014, p. 05)

Portanto é importante considerar o pensar dos filosfos antigos, a filosofia pura e clássica, que de veras é uma herança, que nos remete a reflexões não presas, mas intelectivas que perpassam dos sistemas irracionais e racionais, e a eles votam e vão, um caminho que embora pareça de duas vias, é único e glorioso, é um caminho de exercício da cognição humana. Conquanto é de complexidade que a via do rasciocínio se funda, no qual em seu interior reside a curiosidade, o saber, o impulso por conhecer o modo como conhecemos, o índice do real, e tudo ao gosto de cada indivíduo nutrido por si, e pelo que o mundo o torna. Este efetivamente é um caminho de êxito.

\section{ALGUMAS CONSIDERAÇÕES}

O pensar crítico oferece maior segurança para se chegar ao produto final, ou seja, ao êxito. Os físicos, efetivamente, desenvolvem através da experiência, e através da apropriação dos escrítos filosóficos, estabaleceram um fonte crítica do saber, no entanto é para seletados que esse fato tornou-se plausível ou estável.

Esse pensamento não lhes é mais necessário e suficientemente perspicaz, nas considerações onde se afirma que precisa-se de experimento, de prova concreta para ser ciência, como no caso da consideração de Stephen Hawking no primeiro capitulo de sua obra "O mistério do ser", que afirma que a filosofia morreu.

É nesta consideração que o autor reconhece a separação entre os campos de estudo. Acreditamos que o campo livre de investigação racional, é o do saber filosófico, por não ter um único objeto de estudo. Estuda portanto, essência, estuda evolução, estuda a natureza, estuda comportamento, estuda a origem do homem do cosmo, estuda-se livremente. Já a física, embora seja uma ciência bela, rica, e bem estruturada de formalidade, é apenas uma parte do que compõe o grande conhecimento.

A firmação de Hawking, não faz uma inflexão com a tradicional filosofia, esse pensamento é vestígios de uma insensibilidade legada pelo próprio, com um caráter possivelmente egocêntrico, pois o mesmo a valer-se dos caminhos filosóficos para fazer tal afirmação.

Albert Einstein é um cientista moderno que de maneira cabal advogou a importância da filosofia para a física. 0 mesmo Einstein mostra o quanto é importante para o físico se confrontar com as implicações filosóficas de seu trabalho, embora seja o autor de uma teoria ainda não refutada, ele reconhece que o conhecimento é líquido no sentido de permitir rupturas. 
Esse trabalho foi um grande desafio, pois trata-se de uma resoluta abordagem pelo corpo complexo de ideias filosóficas, para descrever nas entrelinhas de um artigo. Para a generalidade acadêmica o conhecimento a priori deve ser considerado, afinal, somos potencialmente cognoscentes desde o abrir dos oslhos até o seu último fechar. Assim, todas as ideias, aparentemente do 'acaso', podem se tornar conhecimento aplicável, embora isso pareça fonte de revelação a luz de uma ideia inesperada.

Acreditamos que estudos intensos sobre os dois tipos de filosofia presente nos dois pensamentos: físico e filosófico continuam. 0 caminho está iniciando agora, pois discussões como estas requer mais leituras, mais reflexões, mas aqui se encontra um ensaio que permitiu perceber que precisamos pensar, refletir, interrogar, problematizar; ações que a filosofia naturalmente se encarrega de imbuir em nosso cotidiano.

Talvez este ensaio, faça uma breve introdução a filosofia da física, que envolve a combinação de assuntos com referências conceituais, metodológicas, de desenvolvimento espistemológico e até mesmo metafísico. SKLAR (1992); SLAVIN (1994); KRAUSE e BUENO (2010).

Enquanto produtores do conhecimento o ato de filosofar é fundamental, o pensamento crítico precisa está presente na produção e apropriação do conhecimento. Sem mais delongas, ressaltamos a importância de um estudo dessa natureza, que possibilitou a busca para relacionar dois pensamentos complexos.

Sendo assim, corroboramos com prática de leituras e pesquisas bibliográficas nos cursos de licenciatura em Física, porque para relacionar dois conceitos que exige estudos, e processo contínuo de leitura, a fim de, promover um entendimento justo, harmonioso do legado que os gigantes deixaram.

\section{REFERÊNCIAS}

[1]. BRENNAN. Richard. Gigantes da física: Uma historia da física moderna através de oito biografias. Rio de Janeiro: Revista brasileira zahar, 2003.

[2]. COSTA, Marcos Antonio F. da; COSTA, Maria de Fátima Barrozo. Projeto de Pesquisa: Entenda e faça. Rio de Janeiro: Vozes, 2011.

[3]. DAHMEN, Silvio R. Einstein e a Filosofia. Revista Brasileira de Ensino de Física, v. 28, n. 1, p.3-

7 , 2006. Disponível em:http://www.scielo.br/pdf/rbef/v28n1/a02v28n1.pdf Acesso: 03/03/2016.

[4]. GIL, Antonio Carlos. Como elaborar projetos de pesquisa. 5 ed. São Paulo: Atlas, 2010.

[5]. KANT, Immanuel. Crítica da Razão Pura. 5a Edição. Trad.: Manuela Pinto e Alexandre Morujão. Lisboa: Fundação Calouste Gulbenkian, 2001.

[6]. KRAUSE, Décio; BUENO, Otávio. Filosofia da Física Quântica: a título de prefácio. Manuscrito - Revista Internacional de Filosofia. Campinas, v. 33, n. 1, pp. 7-18, jan.-jun. 2010.

[7]. LOPARIC. Zeljiko. As duas metafisica de kant. Unicamp/ PUCS/PUCRS. Kant e-Prints - Vol. 2, n. 5, 2003. Disponível em: http://egov.ufsc.br/portal/sites/default/files/anexos/30281-31156-1- PB.pdf.

a. MORIN. Edgar. Ciência com consciência. Revista brasileira Bertrand, 2013. Disponível em: http://www.filosofiatematica.ufpa.br/index_htm_files/ciencia_com_conciencia.pdf

[8]. PASSOS, Luiz Augusto. Fundamentos de Filosofia: os caminhos do "Pensar" para quem quer transformação /

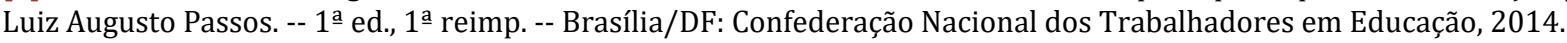

[9]. PRADO Jr., Caio. O que é filosofia. São Paulo: Brasiliense, 1981.

[10]. RODRIGUES. Caique Conde. NEME. Maíra Dombroski. Efeito Fotoelétrico. Instituto de Física "Gleb Wataghin" - UNICAMP; 2017.

[11]. SILVA. Cibele Celestino. Estudo de Historia e filosofia das ciências. Livraria brasileira de física, São Paulo 2006.

[12]. SILVEIRA, Fernando Lang. A Teoria do Conhecimento de Kant: O Idealismo transcendental. Instituto de Física UFRGS Porto Alegre - RS. Disponível em: http://www.if.ufrgs.br/ lang/Textos/KANT.pdf Acesso 03/03/2016.

[13]. SKLAR, Laurence. Philosophy of Science. Oxford University Press, ed, 1992.

[14]. SLAVIN, Alan J. A Brief History and Philosophy of Physics. Agosto de 1994.

[15]. VITTE, Antonio Carlos. A Concepção de Geografia Física em Immanuel Kant. 10 Seminário de História da Ciência e da Tecnologia. Belo Horizonte, CD-ROOM, 2005. 


\section{Capítulo 4}

Perfil psicomotor de uma criança de oito anos de idade: Estudo de caso

\section{Maria Anailsa dos Santos Furtado Dias \\ Elaine Christina Monteiro de Oliveira \\ Noélia Kally Marinho de Sousa \\ Patrícia Emille Bento Gonçalves \\ Hilana Maria Braga Fernandes Abreu}

Resumo: Vários fatores são responsáveis pelo desenvolvimento biopsicossocial de um ser, capacitando-o ao seu pleno desenvolvimento físico e mental, habilitando-o a interagir com o meio, fazendo uma inter-relação entre psicologia, pedagogia e neuroanatomia. 0 presente estudo de caso buscou nos fundamentos da psicomotricidade justificar tal intuito, posto que as estruturas psicomotoras contribuem no processo de desenvolvimento global das crianças. Como metodologia utilizou-se uma abordagem qualitativa e descritiva dos dados levantados a partir da aplicação das atividades propostas pela Bateria Psicomotora - BPM, sugeridas por Fonseca (2012). A análise da bateria psicomotora buscou observa na criança um melhor desempenho relacionado à atenção, ao equilíbrio e à coordenação motora global e fina. Tomando por base o somatório geral das pontuações em tonicidade, equilibração, lateralização, noção de corpo, estruturação espaço-temporal, praxia global e praxia fina, chegou-se ao total de 21 pontos, o que caracteriza um perfil eupráxico, ou seja, a realização das atividades foi exercida de forma controlada e adequada, obtendo uma boa classificação.

Palavras-Chave: Perfil Psicomotor, Bateria Psicomotora, Criança. 


\section{INTRODUÇÃO}

0 presente trabalho apresenta informações acerca dos fundamentos da psicomotricidade, que podem ser caracterizados como estruturas psicomotoras que evoluem ao longo do tempo com o sujeito, proporcionando assim o seu desenvolvimento e estruturação. De acordo com Fonseca (2012), a bateria psicomotora (BPM) surgiu da perspectiva clínica e psicopedagógica, com o objetivo de identificar e compreender problemas relacionados à aprendizagem e ao desenvolvimento da criança, ajudando a identificar crianças que não possuem as aptidões psicomotoras, indispensáveis a sua aprendizagem. Segundo Fonseca (2012 p.14)

A bateria psicomotora é uma escala do desenvolvimento motor e trata-se de instrumento fundamentado em tarefas que permitem identificar déficits funcionais em termos psicomotores, relacionado com a perspectiva sensorial e com a potencialidade de aprendizagem da criança.

Esse instrumento de avaliação ajuda na detecção de problemas de crianças e jovens entre quatro e doze anos de idade, não se trata de um exame neurológico, mas sim uma ferramenta de identificação de sinais psicomotores que possam explicar o potencial de aprendizagem em crianças. Para Fonseca (2012), a bateria psicomotora (BPM) compreende sete fatores: tonicidade, equilibração, lateralização, noção do corpo, estruturação espaço-temporal, praxia global e praxia fina, que se subdividem em 26 subfatores.

0 relato de caso descrito a seguir, objetiva apresentar o perfil psicomotor de uma criança de 8 anos de idade, e averiguar se o mesmo encontra-se em desenvolvimento adequando para sua faixa etária. Justificando-se, neste sentido, pela necessidade de discutir o desenvolvimento das potencialidades motoras e neurológicas da criança e, assim favorecendo-o seu desenvolvimento e estruturação no decorrer da vida.

Tomando o corpo como referencial, o ponto de partida para toda a atividade humana, é possível compreender o mundo como um filtro, que acaba regulando suas interações. 0 homem ao dominar-se fala de seu corpo e em contrapartida, seu corpo fala por ele em qualquer situação.

Assim como os aspectos somáticos e os desvios corporais, o controle respiratório é o primeiro fator que deve ser observado durante a realização da BPM, logo são passos que se dão no primeiro contato com a criança. É necessário observar como se dá a expiração e inspiração, o controle da apneia bem como os sinais de fadiga apresentados por ela. 0 controle respiratório reflexo é muito importante, e deve ser trabalhado de forma lúdica. Sobre essa temática Fonseca (2012 p. 108) afirma:

O controle respiratório reflexo é um dos processos vitais que envolve inspirações e expirações cíclicas, em que participam os músculos intercostais e o diafragma(...) 0 controle respiratório, porém pode ser realizado conscientemente, e é esse, essencialmente que se procura analisar em termos lúdicos por meios de situações de inspiração, expiração e apneia.

Baseada na literatura de Fonseca (2012) "a tonicidade compreende todos os músculos do ser, os responsáveis pelas funções biológicas e psicológicas, bem como toda e qualquer forma de relação e comunicação social não verbal." A principal característica é o seu baixo nível energético, a qual permite ao ser humano ficar de pé por mais tempo sem apresentar sinais de fadiga. A passividade é defendida por Ajuriaguerra e Stambak (1955) citado por Fonseca (2012) "como a capacidade de relaxamento passivo dos membros e suas extremidades distais".

De acordo com Fonseca (2012), o fator equilíbrio abrange o nível de organização neurológica do tronco cerebral, do cerebelo e dos gânglios da base que estão contidos dentro da primeira unidade funcional do modelo psiconeurológico de Luria e se relacionam com as funções de vigilância, alerta e atenção. 0 equilíbrio é tido como uma condição básica a organização psicomotora e ao ajustamento postural. Segundo Fonseca (2012) a lateralização, terceiro fator da BPM, respeita a progressiva especialização dos dois hemisférios que resultam das funções sócias históricas da motricidade laboral e da linguagem (motricidade colaboral).

Constituindo-se o quarto fator da Bateria psicomotora - BPM, a noção de corpo que tem como objetivo fundamental a recepção, análise e o armazenamento de informações, acerca do mundo que circunda o sujeito em constante desenvolvimento. 0 desenvolvimento da noção do corpo encontra-se interligado com outros fatores da BPM: como a tonicidade, equilíbrio e lateralidade (PEREIRA, 2005). 
O fator de Estrutura espaço-temporal é desenvolvido de acordo com o desenvolvimento de outros fatores anteriores, sendo necessária a lateralidade, bem como as noções de corpo da criança apresentarem-se bem definidas. A praxia global é responsável pela execução de atividades como caminhar, saltar, correr, arremessar entre outras coisas.

Segundo Mendes e Fonseca (1998), citado por Pereira (2005) afirmam que a praxia global é um movimento intencional e organizado objetivando um resultado. Não é considerada autônoma, e sim um movimento voluntário, consciente e inibido, ou seja, há o envolvimento de um planejamento cortical e do sistema de autorregulação.

Quanto à praxia fina, esta constitui o sétimo e último fator psicomotor, integrando todas as significações psiconeurológicas já avançadas na praxia global. Dentro da praxia fina objetiva-se avaliar a maturidade práxico-manual e a dissociação digital complementando com o controle tônico emocional.

\section{METODOLOGIA}

0 estudo de caso tornou-se exequível, com uma criança do sexo masculino de 08 (oito) anos de idade. 0 relato de caso apresentado utilizou-se ainda de uma abordagem qualitativa e descritiva dos dados levantados a partir da aplicação das atividades propostas na BPM, sugeridas por Fonseca (2012) em comunhão com recursos lúdicos.

\section{RESULTADOS E DISCUSSÃO}

0 relato apresentado a seguir descreve o resultado de todos os fatores e subfatores observados na BPM, durante as atividades aplicadas com a criança. Visando $\mathrm{Na}$ realização da bateria psicomotora, primeiramente observou-se os desvios posturais da criança, o controle respiratório, a amplitude torácica, o ritmo respiratório bem como sinais de fadiga presentes durante a realização do procedimento com a criança.

Tratando-se do controle respiratório, amplitude toráxica e ritmo respiratório a criança apresentou resultados satisfatórios, executando as tarefas propostas na BPM de forma correta e controlada sem apresentar sinais de fadiga. Segundo Fonseca (2012) a tonicidade, visa garantir de forma interativa as atitudes, postura, mímica e emoção de onde emergem todas as atividades motoras humanas.

Como primeiro fator para realização da atividade com acriança, tem-se o aspecto somático, desvios posturais e controle respiratório. No processo de inspiração e expiração, a criança realizou o procedimento de inspirar e expirar, de forma bastante satisfatória, controlada e com perfeita realização da tarefa, a qual se atribuiu à cotação de número 4; a criança realizou as quatro inspirações ou expirações correta e controladamente (Fonseca, 2012).

$\mathrm{Na}$ atividade da apneia, a criança realizou a tarefa de forma bastante satisfatória com o tempo de 35 segundos, não apresentando sinais de fadiga nem de cansaço ao longo do tempo onde a respiração ficou bloqueada. Sendo assim atribuída de acordo com Fonseca (2012), a cotação de número 4, pois a criança se manteve em bloqueio torácico acima de 30 segundos sem sinais de fadiga.

Já na atividade de fadiga, a criança se mostrou bastante atenciosa e motivada a realizar as atividades solicitadas à mesma, sendo assim visível a sua satisfação em estar participando do procedimento, bem como não apresentou sinais de fadiga e se manteve assim durante toda a realização de ambas as tarefas. De acordo com Fonseca (2012), atribui-se a cotação de número 4, visto que a criança não evidenciou nenhum sinal de fadiga, mantendo-se motivada e atenta durante todas as tarefas.

A tonicidade constituiu-se como o primeiro fator representado na BPM. Os primeiro subfator é a extensibilidade. Na realização da atividade com a criança dos membros inferiores, a mesma conseguiu atingir um ângulo de $120^{\circ}$ nos adutores e nos extensores da coxa, bem como um afastamento de 17 centímetros nos quadrícepetes femurais, identificou-se também uma resistência máxima, mas não com sinais tônicos disfuncionais, ou seja, a criança apresentou certas dificuldades mais realizou o procedimento consideravelmente. Dessa forma de acordo com Fonseca(2012) atribuiu-se a cotação 3; a criança atingiu entre $100^{\circ}$ e $140^{\circ}$ de afastamento, nos adutores e nos extensores da coxa e um afastamento de $15 \mathrm{~cm}$ a $20 \mathrm{~cm}$ nos quadrícepedes femurais, a resistência é máxima, não se identificando sinais tônicos disfuncionais. 
Na atividade de extensibilidade dos membros superiores, a criança também obteve a mesma cotação da atividade anterior de modo que, a mesma apresentou certas dificuldades na realização da tarefa proposta, mas realizou de forma esforçada. Outro subfator da extensibilidade é a passividade, a criança realizou a atividade com algumas resistências, e mobilização forçada. Sendo assim de acordo com Fonseca (2012), a cotação atribuída foi de número 3, visto que a criança obteve a mesma realização descrita na cotação anterior, mas com uma maior resistência e uma mobilização mais assistida e forçada. Alguns sinais de esforço foram percebidos.

$\mathrm{Na}$ atividade de passividade a criança realizou a atividade com ligeiras descontrações musculares e insensibilidade no peso dos membros. Dessa forma de acordo com Fonseca (2012) atribuiu-se 3, porque a criança revelou descontração muscular e ligeira insensibilidade no peso dos membros; provocando pequenos movimentos voluntários de oscilação ou pendularidade; ligeiras manifestações emocionais nas ausências de sinais de resistência ou bloqueio, sem evidência de movimentos coreiformes ou atetotiformes na passividade.

A paratonia teve como objetivo identificar a incapacidade ou a impossibilidade de descontração voluntária. A criança durante a realização da tarefa com os membros inferiores apresentou leves tensões, e resistências, mas conseguiu abandonar os membros, obtendo assim uma boa capacidade de relaxamento ao longo da atividade realizada. Já nos membros superiores a criança se mostrou bastante relaxada, sem revelar sinais de tensões ou resistências. A cotação atribuída de acordo com Fonseca (2012) foi a de número 3, uma vez que a criança revelou tensões ligeiras e resistências muito fracas em qualquer das manipulações, identificação de uma capacidade de abandono, de autorrelaxamento e de autodescontração completa e adequada; ligeiras manifestações emocionais; Já a cotação para os membros superiores deu-se da seguinte forma 4, a criança não revelou tensões ou resistências em qualquer das manipulações dos quatro membros; identificação de uma capacidade de abandono, de autorrelaxamento e de auto descontração perfeita, precisa e com facilidade de controle; ausência total de manifestações emocionais.

A diadocosinesias objetivou a realização de movimentos vivos, simultâneos e alternados. Sendo assim de acordo com Fonseca (2012) a cotação atribuída foi 2, porque a criança realizou os movimentos de pronação e supinação descoordenadamente e dismetricamente, sem amplitude ou arritmicamente, desajeitadamente e embaraçadamente (disdiadococinesias), a mão esquerda realizou nítidos movimentos em espelho.

As sincinesias objetivaram observar as reações parasitas de imitação dos movimentos contralaterais e de movimentos peribucais ou linguais. A criança realizou a atividade demostrando tanto para as sincinesias bucais como contralaterais. Sendo assim segundo Fonseca (2012) a cotação atribuída foi 3, a criança realizou as tarefas com sincinesias contralaterais pouco óbvias e discerníveis, quase imperceptíveis; realização adequada e controlada; detecção de ligeiros movimentos ou contrações tônicas associadas à função de vigilância, de alerta e de atenção os quais dispõe a criança.

A equilibração foi o segundo fator da BPM realizado, que visou apontar e compreender subfator foi de imobilidade que visou observar a capacidade de inibir voluntariamente todo e qualquer movimento durante um curto espaço de tempo. A criança realizou a atividade dentro de 60 segundos de tempo exato, com rápidos movimentos na face, gestos, sorrisos e movimentos alternados do corpo, apresentando uma realização da atividade adequada. De acordo com de Fonseca (2012) a cotação atribuída foi a de número 3, porque a criança se manteve imóvel entre 45 e 60 segundos, revelando ligeiros movimentos faciais, gesticulações, sorrisos, oscilações, rigidez corporal, tiques, emotividade, ou seja, uma realização completa adequada e controlada.

O equilíbrio estático constituiu-se como segundo subfator da equilibração, e objetivou a capacidade de imobilidade, em três provas: apoio retilíneo, manutenção do equilíbrio na ponta dos pés e apoio unipedal. Durante a atividade de apoio retilíneo, a criança manteve o equilíbrio de 14 segundos sem abrir os olhos, com dificuldades de se manter na posição, bem como de manter o equilíbrio também. Como bem esclarece Fonseca (2012) à cotação a ser atribuída neste caso, é a de 2; a criança se manteve em equilíbrio entre 10 segundos sem abrir os olhos, revelando dificuldade de controle e disfunções vestibulares e cerebelosas; frequentes movimentos associados.

No apoio unipedal a criança tendeu-se a se apoiar no pé direito, ficando assim por 8 segundos na posição de apoio com um pé só, revelando claros sinais de desequilíbrio e tentativas de equilibrar-se abrindo os braços. Sendo assim na literatura de Fonseca (2012) a cotação atribuída foi a seguinte: 1, a criança se manteve em equilíbrio 10 segundos sem abrir os olhos, ou se a criança não realizou tentativas; sinais de disfunções vestibulares e cerebelosos bem marcados, permanentes reequilibrações, quedas; movimentos de compensação das mãos contínuos etc. 
A lateralização constituiu o terceiro fator da BPM, que objetivou analisar a recepção, análise e o armazenamento da informação na criança. Na lateralização foram observados quatro subfatores: lateralização ocular, onde pediu à criança que olhasse através de um tubo ou canudo de papel e depois de um buraco feito em uma folha de papel. Na lateralização auditiva, a criança recebeu também tanto o relógio como o celular com a mão esquerda e ouviu tanto as batidas do relógio como simulou atender o celular com a mão esquerda também. Na realização da atividade de lateralização pedal, a criança tanto no passo gigante como na simulação de vestir a calça iniciou com a perna esquerda.

Sendo assim de acordo com Fonseca (2012) a cotação a atribuída foi a de 4 - porque a criança realizou todas as tarefas espontaneamente, sem hesitações e com proficiência, podendo obter-se um perfil DDDD no caso da criança com preferência direita, ou um perfil EEEE no caso de criança de preferência esquerda, nenhum sinal difuso ou bizarro deve ser perceptível, realização precisa, econômica e perfeita. Segundo informações da mãe da criança, a lateralidade da criança não é adquirida, e sim inata, pois desde pequena ela realiza atividades e se orienta com a mão esquerda. A autoimagem (face) segundo Fonseca (2012) refere-se a um componente facial da noção do corpo, envolvendo sua localização e diferenciação tátilquinestésia como a harmonia e eumetria dos movimentos no espaço envolvendo o corpo. Para essa atividade foi à atribuída a cotação de número 3 a criança falhou uma ou duas vezes, mantendo um movimento adequado e controlado sem manifestar outros sinais disfuncionais.

De acordo com Fonseca (2012) o desenho do corpo também se incluiu no fator noção de corpo foi uma representação do corpo vivido da criança, para a realização da mesma a criança realizou a principio um desenho do seu corpo, a criança desenhou em uma folha normal e dispôs do tempo necessário para realizar o desenho. A estrutura espaço-temporal foi relacionada com a capacidade de estruturar e organizar o espaço sendo essencial para qualquer aprendizagem. A cotação atribuída foi a de número 3 a criança realizou os três percursos com ligeiros descontrole final das passadas (alargamento ou encurtamento), mantendo correta a contagem e o cálculo.

Segundo Fonseca (2012) a estrutura dinâmica compreendeu a capacidade de memorização sequencial visual, trata-se de uma tarefa que apreciou a capacidade de memória da criança. A cotação atribuída foi a de número 3 - a criança em idade escolar realizou quatro das seis tarefas ou se a criança em idade préprimária realiza a ficha de ensaio mais as duas primeiras fichas.

A representação topográfica compreendeu um componente visório-espacial, uma reorganização espacial por meio da trajetória efetuada, envolveu também uma codificação e memorização. Para essa atividade a cotação atribuída foi a de número 2 a criança realizou a trajetória com frequentes hesitações, interrupções, desorientações angulares, desproporções espaciais e direcionais óbvias.

$\mathrm{Na}$ estrutura rítmica segundo Fonseca (2012) compreendeu-se a capacidade de memorização e reprodução motora de estruturas rítmicas. Para essa atividade a cotação atribuída foi a de número 2 a criança reproduziu três das cincos estruturas, revelando irregularidades, alterações de ordem e inversões, demonstrando dificuldade de integração rítmica.

A praxia global constituiu-se do sexto fator da bateria psicomotora teve como objetivo avaliar a coordenação oculomanual compreendendo a capacidade de coordenar movimentos manuais, requer uma coordenação dos membros superiores normalmente da mão dominante, avaliando a distância de precisão de lançamento. Sendo dessa maneira atribuída cotação de número 1, a criança não enfia nenhum lançamento revelando dispraxias, distonias, disquinesias, discronias obvias, além de sincinesias, reequilibrações, hesitações de dominância, desorientação espaço-temporal, movimentos careoatetoides (Fonseca, 2012). No subfator da dismetria não avalia uma atividade especifica, pois a mesma vai resultar das duas coordenações quer dos membros superiores, quer dos membros inferiores. Para esse subfator a cotação atribuída à criança foi à cotação de número 2, a criança realizou as tarefas com dismetrias movimentos exagerados e insuficientemente inibidos (Fonseca, 2012).

Segundo Fonseca (2012) para a realização desse subfator, a dissociação não foi necessário nenhum material, apenas pede à criança que siga uma sequência de membros superiores, membros inferiores e a coordenação entre os membros superiores e inferiores. A cotação atribuída à criança foi a de número 4 a criança realizou as quatro estruturas sequenciais ou três das quatro revelando perfeito planejamento motor e preciso autocontrole, com melodia quinestésia e eumetria. 
Segundo Fonseca (2012) a praxia fina, constituiu o sétimo e último fator psicomotor ela integra todas as significações psiconeurológica já avançadas na praxia global. Dentro da praxia fina encontra-se a coordenação dinâmica manual. A cotação atribuída à criança foi à cotação de número 2, porque a criança compões e decompõe a pulseira entre 3 e 5 minutos, revelando dispraxias, dismetrias, disquinesias, distonias e dissincronias, além de sinais de desatenção visual e hesitação na lateralização. Na realização do tamborilar deve ser compreendido a localização tátil-quinestésia dos dedos e a sua motricidade independente e harmônica. Nessa atividade a criança atingiu cotação de número 3 a criança revelou o tamborilar, revelando adequando planejamento micromotor com ligeiras hesitações na sequência, ligeiras tensões e dismetrias digitais, repetições de oponibilidades e ligeiras sincinésias contralaterais (Fonseca, 2012).

0 último subfator da praxia fina foi o de velocidade-precisão, que envolveu coordenação praxia do lápis e preferência manual. A cotação para o número de pontos foi considerada a contagem total, sendo assim a criança realizou a cotação de número 3 realizou entre 30 e 50 pontos, revelando adequado planejamento motor e ligeiras hesitações na sequência da tarefa, para o número de cruzes a cotação envolveu também a contagem, menos os fracos a cotação atribuída foi a cotação de 3 a criança realizou entre 20 e 15 cruzes.

Tomando por base o somatório geral das pontuações em tonicidade, equilibração, lateralização, noção de corpo, estruturação espaço-temporal, praxia global e praxia fina, chegou-se ao total de 21 pontos, o que caracteriza um perfil eupráxico, ou seja, a realização das atividades foi exercida de forma controlada e adequada, obtendo uma boa classificação.

Esse perfil se justifica, posto que, durante a realização das atividades a criança apresentou um grau leve de fadiga, ansiedade e outras emoções, que não representou danos maiores a realização das atividades. A análise da educação psicomotora buscou ainda observar na criança um melhor desempenho na atenção, no equilíbrio e na coordenação, as quais apresentaram leves disfunções, não comprometendo o desempenho psicomotor da criança analisada, como contraponto, percebeu-se que houve uma construção do conhecimento adquirido nos momentos dos jogos e das brincadeiras.

\section{CONCLUSÃO}

A partir da análise dos resultados pode-se concluir que foram encontradas dificuldades pela criança em algumas atividades, sendo que a mesma atingiu o nível de pontuação estimado na maioria das atividades que foram realizadas. Pode-se notar, que a criança teve um desempenho intermediário nos testes de habilidades psicomotoras, sendo assim, a partir da analise apresentada os resultados foram parcialmente atingidos.

É importante ressaltar que quando o infante ingressa na vida juvenil um novo mundo com um universo de produção e decodificação de signos e significados lhe é apresentado. Para que esse processo possa ser de fácil vivência, é necessário que o seu sistema motor seja aperfeiçoado por meio de experiências. As atividades psicomotoras, aliadas a vivência lúdica quando bem trabalhadas possuem características inerentes, a criatividade, a sensibilidade, à disponibilidade, e até mesmo a alegria, o prazer e o divertimento.

\section{REFERÊNCIAS}

[1] FONSECA, V. Manual de observação psicomotora: significação psiconeurológica dos fatores psicomotores/ Vitor da Fonseca- 2a Ed.- Rio de Janeiro, 2012.

[2] PEREIRA, K. Perfil psicomotor: Caracterização de escolares da primeira série do ensino fundamental de colégio particular. Universidade Federal de São Carlos/ Sp, 2005. 


\section{Capítulo 5}

\section{O ensino religioso na leitura e escrita no ato da criança}

\section{Maria Selta Pereira}

Resumo: Este trabalho "o ensino religioso da leitura e escrita no ato da criança", traz aspectos dos conceitos históricos e a evolução da disciplina de ensino religioso no ambiente da escola pública e algumas entidades (ongs) que se dispõe trabalhar com aspectos sociais e aprendizagem das crianças e adolescentes, envolvendo o processo de leitura e escrita. Esses ambientes que foram trabalhados fazem parte da periferia de fortaleza. Este trabalho foi elaborado para dar ênfase as necessidades de um olhar para a compreensão da criança com relação a disciplina de ensino religioso, o embasamento teórico, ao desenvolvimento de diversos conceitos tanto no aspecto histórico, com no aspecto da aprendizagem da leitura e escrita. 0 método utilizado foi a entrevista, analise dos desenhos e bibliográfico, em que vários autores fizeram parte dessa pesquisa, tais como: Antunes (2010); Ferreira (2007); Junqueira (2007); Sena (2007) entre outros. Portanto, ficam estabelecidas as principais ideias da evolução da lentidão do ER, e a relação do aprendente com a disciplina tão sem vida, sem emoção do aprender.

Palavras-Chave: Ensino religioso. Aprendizagem. Leitura e escrita. 


\section{INTRODUÇÃO}

A disciplina de Ensino Religioso é vista com bastante preconceito e exclusão diante da formação humana, mas diante dos aspectos históricos e sociais tem evoluído na compreensão de alguns educadores e tem adquirido vigor em algumas cidades do Brasil.

Portanto muitos aprendentes e ensinantes desconhecem seus valores históricos e legais.

Quanto à formação dos educadores na perspectiva fica a desejar, pois não são valorizados. Mas, atualmente alguns avanços têm acontecido com a criação das Diretrizes Municipais de Fortaleza, e o Ensino Religioso vem assegurar o direito dos educando a disciplina.

Ampliando essa reflexão deparamos com o processo de leitura e escrita bem restrito nesse contexto. Fica então a problemática: 0 que os alunos estão lendo e escrevendo nos ambientes de processo de formação do leitor escritor? Que livros sagrados são utilizados?

Diante dessas reflexões procuramos investigar com olhar psicopedagógico na disciplina de Ensino Religioso e compreender o desenvolvimento da criança e adolescente diante do Ensino Religioso e na formação do leitor e escritor.

Esse trabalho está dividido em dois capítulos. 0 primeiro focaliza o ensino religioso e seus aspectos históricos e conceituais no Brasil e no Ceará. O segundo capítulo explica o conhecimento da leitura e da escrita e uma visão psicopedagógica nas culturas religiosas, também na compreensão das crianças e dos adolescentes diante das atividades desenvolvidas na disciplina do ensino religioso. Por fim a considerações finais e as referências com os autores que ajudaram na elaboração dessa pesquisa.

Segundo Rubem Alves (2010) a ciência, em princípio, nega a religião, mas a religião existe. Constitui-se num sistema de fatos dados, é uma realidade. Portanto, Ensino Religioso (ER) tem passado por diversos processos de formulação e reestruturação. E o que temos definido atualmente por lei.

\subsection{CONCEITOS DE ENSINO RELIGIOSO}

De início foi bastante autoritário, vivenciamos esses aspectos até hoje, alguns são a favor, outros são contra a disciplina de ER. Portanto, cabe aos setores criarem um clima de valorização. O ER iniciou-se com processo de evangelização, com a chegada dos jesuítas ao Brasil em seguida, com a Companhia de Jesus que tinham como objetivo catequizar, doutrinar principalmente os índios e negros escravos. .

E com toda evolução estudiosos e pesquisadores começaram a tentar distinguir (diferenciar) o processo de evangelização (catequese) e a disciplina de ER (área de conhecimentos) segundo Conferência Nacional dos Bispos do Brasil (CNBB).

Símbolo da relação de poder entre ato social e políticos, líderes religiosos parlamentares, legisladores, alguns setores da sociedade o que incluem e ao mesmo tempo, o excluem da sua condição normal no sistema de ensino. Não tem ainda o tratamento que lhe devido, em grande parte das instituições escolares (CNBB, 2007, p. 38).

No período 1988 a 1996, dois projetos da Nova Lei de Diretrizes e Base (LDB, BRASIL, 1996) se encontram em circulação no Congresso Nacional, e o ER busca compreender a sua própria natureza e redefinir-se como disciplina escolar. 
$\mathrm{Na}$ realidade, a prática ultrapassa as categorias sinalizadas pelo: confessional, interconfessional e a ecumênico. No entanto, existem escolas que preferem admitir aspectos religiosos, como qualidade própria do ser humano, direcionando para diversas formas de manifestações religiosas em diversas culturas. Então podemos dizer que "o ensino será inter-religioso, terá modalidade interdisciplinar e transdisciplinar." (CNBB, 2007, p. 93).

Enquanto isso, dois projetos de Lei de Diretrizes e Base da Educação circulam no Congresso Nacional. Nesse inclui o ER nos termos das relações anteriores, eliminando-se o parágrafo único, que assegurava atividades alternativas para alunos que não optassem pelo ensino religioso (CNBB, 2007, p. 93).

Art. 38. 0 currículo de ensino fundamental obedecerá ao disposto no capítulo VI, acrescidas as seguintes diretrizes: (...) II - o ensino religioso, de matrícula facultativa, constituirá disciplina dos horários normais das escolas públicas de ensino fundamental (CNBB, 2007, p. 93).

O ER, disciplina dos horários normais escolares, deve ser administrado por professor da área específica das ciências da Religião e de matricula facultativa para os municípios ou escolas que não queira administrá-la, mas obrigada quando estabelece que todo o conhecimento humano é sempre patrimônio da humanidade, o conhecimento religioso deve também estar disponível a todos os que a ele queiram ter acesso.

Assim, o ER é facultativo para o município ou escolas que queiram ofertar a disciplina, mas encontramos muitos livros e revistas que indicam matricula facultativa para o aluno. Assim,

0 homem é naturalmente religioso não só de fato, mas também de direito: Como ele não é homem se é carente de inteligência, de vontade, de cultura, de linguagem, assim também ele não é homem se é carente de religião [...] é quase impossível imaginar ou querer provar que existiu grupos humanos que não acreditassem em alguma divindade [...] a dimensão religiosa é inerente a toda pessoa humana (FERNANDES, 2000, p. 61).

Como sempre é jogada a situação problema para escola e professores com sua formação reduzida. Faz-se necessário uma reflexão ampla da situação atual do ER no campo educacional. Não é competência da escola ensinar o que cabe às famílias e as igrejas. A escola deve criar oportunidade para que os educados e educadores percebam e valorizem sua dimensão espiritual, para que sejam eliminados os preconceitos, para que todos sejam ajudados a viver, consciente e plenamente, suas escolhas religiosas ou não, respeitando amorosamente as diferentes opções de vida de seus semelhantes. Em seguida, o Conselho de Educação do Ceará (CEC), na Resolução no 404/2005, no art. 3, expõe os objetivos do Ensino Religioso.

I - subsidiar o estudante na compreensão do fenômeno religioso, presente nas diversas culturas e sistematizado por todas as tradições religiosas;

II - articular o conhecimento religioso com os demais conhecimentos que integram a formação do cidadão;

III-introduzir o respeito diversidade;

IV - promover a prática de atitudes respeitosas em relação ao outro e à natureza;

V - incentivar a fraternidade e a solidariedade na convivência social;

VI - despertar nos alunos o interesse pelos valores humanos;

VII - orientar para uma formação harmonizadora dos aspectos somáticos, emocionais espirituais do educando (CEARÁ, SEDUC, 2005, p. 69/70).

Segundo Rubem Alves (2010) em seu livro “O que é religião?” expressa que a experiência religiosa, assim, depende de um futuro. Ela se nutre de horizontes utópicos que os olhos não viram e que só podem ser contemplados pela magia da imaginação. Deus e o sentido da vida são ausências, realidades por que se anseia, dádivas de esperança. De fato, talvez seja esta a grande marca da religião: a esperança. 


\subsection{ASPECTOS HISTÓRICOS O ER NO CEARÁ}

No Ceará, a Resolução 404, de 14 de setembro de 2005, do CEE$^{9}$ do Ceará, dispõe sobre o ER a ser ministrado nas escolas públicas de ensino fundamental. Nas entrelinhas dessa Resolução os princípios da descentralização e da autonomia para que as escolas incluam em seu projeto político pedagógico, como também seus conteúdos, levando em considerações as Diretrizes Curriculares Nacionais e os Parâmetros Curriculares estabelecidas sob a coordenação da SEE ${ }^{10}$. Tais conteúdos devem ser focados tendo em conta os objetivos estabelecidos no art. 3, como esclarece Junqueira (2007, p. 69).

I- Subsidiar o aluno na compreensão do fenômeno religioso, presente nas diversas culturas e sistematizado por todas as tradições religiosas;

II- articular o conhecimento religioso com os demais conhecimentos que integram a formação do cidadão;

III- induzir o respeito a diversidade;

IV- promover a prática de atitudes respeitosas em relação ao outro e à 'natureza;

V- incentivar a solidariedade na convivência social;

VI- despertar nos alunos o interesse pelos valores humanos;

VII- orientar para uma formação harmonizadora dos aspectos somáticos, emocionais e espirituais do educando.

Na resolução 404, apresenta dois aspectos. 0 primeiro referente à ideia de que estarão habilitados para ER, os portadores de licenciaturas plana em Ciências da Religião com habilitação em ER, obtido em curso regularmente reconhecido. Na falta do docente com essa habilitação, a disciplina será administrada, supletivamente. E, como indica Junqueira (2007, p. 70).

I- nas séries iniciais do ensino fundamental, por professor que comprove as duas exigências abaixo:a) a formação religiosa obtida em curso oferecido por instituição religiosa, que observe os aspectos formais das diretrizes curriculares, estabelecidas na Resolução 351/98. CEE/CE, justificada pelo Parecer 0997/98, que aprovou os parâmetros curriculares propostos pelo Conselho de Orientação do ER do Ceará (Conoere) e pelas Diretrizes do CNE Para os cursos regulares de graduação plena, excluídos os aspectos relativos a conteúdos Curriculares contido nos documentos citados: b) a conclusão do curso normal superior reconhecido, ou um curso reconhecido de Pedagogia ou qualquer outro, reconhecido, de formação de professores, que, igualmente, habilite para o magistério das series iniciais do ensino fundamental;II- nas séries finais do ensino fundamental, por docente que apresente formação obtida em curso de graduação reconhecido e seja habilitado por Programa Especial de Formação Pedagógica, voltada para o ER, regulamentada pela Resolução 02/98 do CNE/CEB ou por legislação sucedânea sobre a espécie, oferecida por instituição de ensino credenciada.

O segundo orienta as instituições particulares, não confessionais, que desejarem ofertar o ER, a inclusão no Projeto Pedagógico da escola. E as de natureza confessional, independente da denominação religiosa que praticam, deverão pauta-se por essa Resolução.

\subsection{DIRETRIZES DO MUNICÍPIO DE FORTALEZA}

O ER no Município de Fortaleza vem criando espaços para o dialogo, mas de forma singela.

As diretrizes Curriculares para o ER foram elaboradas com perspectiva de ampliar e envolver os profissionais do ER, como também dar conta do conteúdo programático e carga horária. Após diversos encontros de estudos entre técnicos da SME, professores da UFC e professores representantes da rede municipal se conclui as diretrizes com diversos objetivos, considerando todos desafios encontrados na

${ }^{9}$ CEE-Conselho Estadual de Educação

${ }^{10}$ SEE- Secretaria Estadual de Educação 
elaboração, que seja o ponto de partida para consolidar o ER, como disciplina de suma importância para a formação básica do cidadão, estabelecendo relações de respeito ao outro em suas diferenças, valorizando a vida, constituindo na ideia da dignidade humana como valor universal. "São requisitos essenciais para estes profissionais, [...] a constante busca do conhecimento das manifestações religiosas, a clareza quanto à sua própria convicção de fé, a consciência da complexidade da questão religiosa e a sensibilidade à pluralidade" (CNER, 2009, p. 43) ${ }^{11}$.

Segundo o ECA ${ }^{12}$ (1990), Lei no 8.069, dispõe sobre a proteção integral das pessoas entre zero e 18 anos, fica estabelecido, no art. 16, que o direito à liberdade, ao respeito e à dignidade compreender os seguintes aspectos:

I) ir, vir e estar nos logradouros público e espaços comunitários, ressalvados as restrições legais;

II) opinião e expressões;

III) crença e culto religioso;

IV) brincar, praticar esportes e divertir-se;

V) participar da vida familiar e comunitária, sem discriminação;

VI) participar da vida política, na forma da lei;

VII) buscar refúgio, auxílio e orientação.

Uma indicação de suma importância é colocada pelo $\mathrm{PNEDH}^{13}$, que vem nortear um dos seus seis princípios:

[...] a educação em direitos humana deve estruturar-se na diversidade cultural e ambiental, garantindo a cidadania, o acesso ao ensino, permanência e conclusão, a equidade (étnico-racial, religiosa, cultural, territorial, físico-individual, geracional, de gênero, de orientação sexual, de opção política de nacionalidade, dentre outras) e a qualidade de educação (BRASIL, 2007, p. 32).

Diante dos debates acontecidos, na Constituição de 1985 até a tramitação da LBD no Congresso Nacional, defendeu a ideia da permanecia do ER como disciplina, de modo que permitisse os educados a oportunidade de compreender sua dimensão religiosa, como também fatores que contribuíram para a formação das diversas religiões.

Sabendo que: a LDB, no art. 33, alterada, pela Lei no 9.475/97, prevê a forma de organização do ER, ao indicar que:

O ER, de matrícula facultativa, é parte integrante da formação básica do cidadão, constituirá disciplina dos horários normais da escola pública do ensino fundamental, assegurando o respeito e à diversidade cultural religiosa no Brasil, vedadas quaisquer formas de proselitismo.

$\S 1^{\circ}$-Os sistemas de ensino regulamentarão os procedimentos para a definição dos conteúdos do ensino religioso e estabelecerão as normas para a habilitação e admissão dos professores (BRASIL, 1997, on line).

Observando a legislação estadual, têm-se as seguintes orientações através do parecer no 449/97, do Conselho de Educação do Ceará “[...] tira-se do Ensino Religiosos toda a conotação catequética tradicional” (CEARÁ, 1997).

Em virtude da resolução de no 07 de 14/12/2010, do CNE, apresenta o ER como uma das dez áreas de conhecimento. De acordo com o art. 14 e em conformidade com o art. 26 da LDB, o currículo da base nacional comum do ensino fundamental deve abrange obrigatoriamente: 0 estudo da Língua Portuguesa e da Matemática; o conhecimento de mundo físico e natural e da realidade social e política, especialmente do Brasil, bem como o ensino da Arte, Educação Física e o Ensino Religioso (BRASIL, 2010, p. 104).

$\mathrm{Na}$ concepção do meio social com relação ao ER, podemos indicar as necessidades que temos para realização da escola com a qual sonhamos, que deve ser permanente na formação intelectual, expansão da criatividade, de humanização, promotora do diálogo inter-religioso e na cultura de paz. Acredita-se na

\footnotetext{
11 Diretrizes Curriculares para o Ensino Fundamental. Vol. 2 p. 101

12 Estatuto da Criança e Adolescente.

13 Plano Nacional de Educação em Direitos Humano.
} 
efetivação dos preceitos legais do ER e das diretrizes Municipais de Fortaleza, depende de diversos fatores que se encontram interligados, a saber:

a) inclusão do ER no Projeto Político Pedagógico da escola [...]

b) mudança de atitude dos profissionais da escola para o diálogo inter-religioso seja uma realidade, o que implica, não apenas tolerar a opção do outro, mas reconhecer seu direito à livre orientação religiosa;

c) garantia de uma política de formação continuada aos profissionais envolvidos com o ER, seja o(a) professor(a) polivalente-pedagogo(a) ou professor(a) com licenciatura especifica, considerando seus saberes e suas trajetórias vida e de formação. Os profissionais que estão na gestão escolar, sobretudo aqueles que se ocupam da coordenação pedagógica também necessitam de uma formação continuada; [...]j) equipar as escolas com livros didáticos do ER e lutar pela inclusão desta área no Programa Nacional do Livro Didático (PNLD) (FORTALEZA, 2011).

Segundo as Diretrizes Municipais de Fortaleza (2011), o ER obedece aos seguintes princípios: antropológico, metodológico, princípio da religião como dimensão constitutiva do ser; princípio político, da pluralidade, da esperança, estético e lúdico, do cuidar do ser. Além dos precipícios básicos, traz como objetivos gerais: propiciar a aprendizagem significativa dos elementos básicos que compõem o fenômeno religioso, analisando as diferentes manifestações do Sagrado a partir da realidade sociocultural do educando; subsidiar o educando com informações fundamentadas para que o mesmo possa encontrar respostas para seus questionamentos existenciais; contribuir para formação da cidadania e convívio ético e pacífico, promovendo o diálogo inter-religioso, o respeito às diferenças, a superação de preconceitos e o estabelecimento de relações democráticas e humanizadoras; analisar o papel das tradições religiosas na estruturação e manutenção das diferentes culturas e no aprendizado da convivência baseada em valores; refletir sobre o sentido da atitude moral, como consequência da religiosidade e expressão da consciência e da resposta pessoal e comunitária do ser humano. Assim, a metodologia do ER deve ser um convite para pensar, opinar, observar, admirar, indagar, problematizar e dialogar.

\section{METODOLOGIA}

O trabalho partiu do curso de formação de psicopedagogia, em seguida partimos para pesquisas bibliográficas como também a pesquisa de campo numa comunidade(bairro) da Periferia de Fortaleza, na área do Grande Canindezinho.

A escola situada próxima a Praça da comunidade, com alunos do 3o ano da Escola Municipal de Fortaleza, e adolescentes da comunidade cristã, próximo a escola. A participação foi por livre e espontânea vontade. A escola é regida pelos valores cristãos e seu funcionamento apresenta três modalidades: Educação Infantil, Fundamental I e II, com coordenação pedagógica, biblioteca e informática educativa e Projeto Mais Educação, e conta hoje com 1.253 alunos, distribuídos em 3 turno (M/T/N), professores concursados e temporários , uma diretoria e um Conselho Escolar seguimento: pais, alunos, professores e agentes administrativos

Foram realizadas:

1. Visitas a diferentes salas, grupos com olhar psicopedagógico para como também no aspecto de ER.

2. Entrevista com alunos e crianças de idades de leitor, fluente; e desenho.

3. Entrevista escrita, relacionado diretamente com processos de conhecimento histórica leitora e escrita.

\section{RESULTADOS}

As entrevistas foram realizadas individualmente, e as falas analisadas, junto aos desenhos de cada participante. Verificamos através dos PCNER, elementos básicos que compõem o Fenômeno Religiosos, a partir das experiência vivenciadas nas escolas, residenciais e comunidades, não se limitam ao meio ambiente como também as relações sociais. De acordo com o professor Francisco Catão(2009,p.31) o estudo dos textos Sagrados no Ensino Religioso é um dos caminhos privilegiados de acesso "ao que há de mais específico em cada religião" 
Portanto, a criança perceber ao seu redor um mundo que o sagrado esta presente mas na forma de fé, acreditar e não como conhecimento da humanidade históricos.

Alguns exemplos de Rodrigues (2012) podem ser citados o quanto as crianças ficam distantes do mundo da leitura na perspectiva da religiosidade, quanto os espaços de formação de leitores não oferecem esse despertar para o aspecto da leitura didática e histórica somente os formatos de evangelização.

\section{CONSIDERAÇÕES FINAIS}

Com os estudos obtidos através dos autores especializados no assunto ora pesquisados constata-se que as dificuldades encontradas, através dos aspectos históricos e como também elementos suficientes que indicam a dificuldade que o aprendente tem em compreender a dimensão do Ensino Religioso. Podemos ainda constatar a ausência de formadores no Ensino Religioso, o desprezo de responsáveis pela disciplina de ER e a indignação de alguns professores diante das situações problemas.

Quanto à formação de leitores e escritores, são espaços em dicotomia ao ER e os ambientes de leitura e escrita (Biblioteca, informática, sala de leitura e outros como também em casa, na Igreja e outros). Ampliando a reflexão buscamos ter um olhar psicopedagógico no processo de formação de leitores e escritores com relação disciplina de ER, visando fazermos uma ampla integração entre os escritos e a realidade nos estudos.

O desafio é encontrar mestres, que sejam conscientes e neutros em sua religiosidade. Para a transmissão do conhecimento bíblico é necessário educadores verdadeiramente comprometidos com a moralidade, pois os pais abordam muito este aspecto.

Que sejam reconstruídos esses aspectos numa perspectiva que valorize o professor da disciplina de ER, e que as expectativas do aprendente se ampliem na quebra da dicotomia, para que haja a reconstrução no processo educacional, diante do Ensino Religioso, com também na formação do processo de leitura e escrita.

\section{REFERÊNCIAS}

[1] ALVES, Rubem. O que É Religião? 11aㅡ ed. São Paulo: Loyola, 2010.

[2] ANTUNES, Celso. A Prática dos Quatros Pilares da Educação na Sala de Aula. Fascículo 17. Petrópolis, RJ: Vozes, 2010.

[3] BONAVIDES, Paulo; AMARAL, Roberto. Textos Políticos da História do Brasil. Brasília: Senado Federal, 1996. (v. 9).

[4] BRASIL, Senado Federal. Lei de Diretrizes e Bases da Educação Nacional. Lei no 9.394/96, de 20 de dezembro de 1996. Disponível em: http://www.planalto.com.br. Acesso em: 12 jun. 2013.

[5] BRASIL, Senado Federal. Lei de Diretrizes e Bases de Ensino. Lei no 4024/61, de 20 de dezembro de 1961. Fixa as Diretrizes e Bases da Educação Nacional. Disponível em: <http://www.planalto.com.br>. Acesso em: 12 jun. 2013.

[6] BRASIL, Senado Federal. Constituição da República Federativa do Brasil de 1988. Disponível em: <http://www.planalto.com.br>. Acesso em: 12 jun. 2013.

[7] BRASIL, MEC. Parâmetros Curriculares Nacionais do Ensino Religioso - PCNER. 2009. Disponível em: <http://www.fonaper.com.br>. Acesso em: 12 jun. 2013.

[8] BRASIL, Senado Federal. Estatuto da Criança e do Adolescente (ECA). Lei no 8.069/1990, de 13 de julho de 1990. Disponível em: <http://www.crianca.caop.mp.pr.gov.br>. Acesso em: 12 Jun. 2013.

[9] BRASIL, Senado Federal. Constituição da República Federativa do Brasil. Carta Magna de 1934. Disponível em: <http://www.ambito-juridico.com>. Acesso em: 12 Jun. 2013.

[10] BRASIL, MEC. Constituição da República Federativa do Brasil, de 24 de janeiro de 1967. Disponível em: <http://www.planalto.com.br>. Acesso em: 12 Jun. 2013.

[11] BRASIL. Comitê Nacional de Educação em Direitos Humanos. Plano Nacional de Educação em Direitos Humanos, 2007. Disponível em: <http://www.dhnet.org.br>. Acesso em: Acesso em: 12 jun. 2013.

[12] BRASIL, MEC/CNE. Resolução no 7, de 14 de Dezembro de 2010. Disponível em: <http://www.sinepemg.org.br>. Acesso em: 12 jun. 2013.

[13] CAPANEMA, Gustavo. Projeto da Lei Orgânica do Ensino Secundário. Rio de Janeiro: Mimeo, 2007.

[14] CATÃO, Francisco. O Fenômeno Religioso. São Paulo: Editora Letras \& Letras, 2009. 
[15] CEARÁ, SEDUC. Conselho de Educação do Ceará. Resolução 404/2005, de 14 de setembro de 2005. Disponível em: <http://www2.cec.ce.gov.br>. Acesso em: 12 Jun. 2013.

[16] CEARÁ, SEDUC. Conselho de Educação do Ceará. Parecer no 449/97, de 3 de março de 1997. Disponível em: <http://www.tcm.ce.gov.br>. Acesso em: 12 jun. 2013.

[17] CNBB. Ensino Religioso no Cenário da Educação Brasileira. Brasília: Ed. CNBB, 2007.

[18] FERNANDES, Maria Madalena S. Afinal, o que é o Ensino Religioso? Sua identidade própria em contraste com a Catequese. São Paulo: Paulus, 2000.

[19] FERREIRA, Márcia. Ação Psicopedagógica na Sala: uma Questão de Inclusão. 7ạ ed. São Paulo: Paulinas, 2007.

[20] FORTALEZA, Diretrizes Curriculares para o Ensino Fundamental do Sistema Público Municipal de Ensino de Fortaleza. Fortaleza: Edições SME, 2011. Disponível em: <http://www.sme.fortaleza.ce.gov.br>. Acesso em: 12 jun. 2013.

[21] JUNQUEIRA, Sérgio Rogério Azevedo. Ensino Religioso: Aspectos Legais e Curriculares. São Paulo: Paulinas, 2007.

[22] PASSOS, João Décio. Ensino Religioso: construção de uma proposta. São Paulo: Paulinas. 2007.

[23] PRANDINI, R. C. A. R., Perspectivas para a análise de entrevistas. In: SZYMANSKI, H. (org.). A entrevista na pesquisa em educação: a prática reflexiva. Brasília: Plano, 2003.

[24] RODRIGUES, Alves, Alexandre. As Escolas devem oferecer Ensino Religioso? Jornal Educação Pública. 2012. Disponível em: <http://www.gper.com.br>. Acesso em: 12 jun. 2013.

[25] ROUSSEAU, Jean-Jacques. Euvres Completes. Vol. 4 Paris: Gallimard, 1967.

[26] SENA, Luzia (org.) Ensino Religioso e Formação Docente: Ciências da Religião e Ensino Religioso em Diálogo. $2^{\underline{a}}$ ed. São Paulo: Paulinas, 2007 


\section{Capítulo 6}

\section{Educação por meio de vivência interdisciplinar: Relato de experiência}

\section{Ruth Nayara Firmino Soares \\ Jônia Cybele Santos Lima}

Resumo: Trata-se de um estudo descritivo que objetiva apresentar um relato de experiência educacional interdisciplinar ocorrido em Unidade Básica de Saúde (UBS) do bairro do panatis, através de encontros exploratórios do território, na cidade de Natal/Rio Grande do Norte. As atividades foram realizadas por alunos da Universidade Federal do Rio Grande do Norte, inseridos na disciplina Saúde e Cidadania (SACI), com supervisão da responsável pela disciplina. A relação entre educação, saúde e cidadania promovida pela vivência, constitui-se como um dos pilares promotores de reflexões e ensejadores de intervenções interdicisplinares a partir da articulação da teoria com a prática, onde a experiência foi efetivada e integralizada enquanto prática que envolve serviço-ensino-comunidade.

Palavras-chave: Educação, Conhecimento, Aprendizagem, Interdisciplinaridade, Universidade. 


\section{INTRODUÇÃO}

O ensino, enquanto prática educativo-criativa requer que os sujeitos produzam saberes, que são indispensáveis para o processo formativo, uma vez que "ensinar não é transferir conhecimento, mas criar as possibilidades para a sua produção ou a sua construção" (FREIRE, 1980, p. 12).

A interdisciplinaridade, por meio do compartilhamento de saberes, corrobora para a formação do pensamento crítivo, constituindo-se como uma estratégia que permite mudanças satisfatórias na prática educativa, possibilitando condições para "aprender para a vida e para a vivência em sociedade" (SANTOS, JÚNIOR, 2017, p.28).

Sendo este um fator de considerável importância para o processo de aprendizagem e qualidade do ensino, favorece a autonomia, senso crítico, consciência cidadã, e o desenvolvimento intelectual, permitindo, dessa forma, "um ensino que faça a ponte entre a teoria e a prática, ligando ciência e trabalho" (PELEIAS et al., 2011, p. 500).

A interdisciplinaridade não é uma idéia recente, mas se manifesta para enriquecer a transformação criada e muitas vezes enfrentada pelos educadores em sua prática docente. À proporção que a interdisciplinaridade cria raízes na práxis docente, o educador e educando forrmam uma visão globalizada da reallidade e consequentemente uma atitude contínua a aprender (LUCK, 2000, p. 13).

Há, portanto, relações entre os diferentes campos de conhecimento que permite multiplicidade de habilidades que se complementam por meio de dialogicidades e integrações, dessa forma, a "interdisciplinaridade está sempre situada no campo onde se pensa a possibilidade de superar a fragmentação das ciências e dos conhecimentos produzidos por elas" (THIESEN, 2008, p. 547).

Considerando o exposto, objetivou-se apresentar um relato de experiência educacional interdisciplinar ocorrido em Unidade Básica de Saúde (UBS) do bairro do panatis, através de encontros exploratórios do território, na cidade de Natal/Rio Grande do Norte.

\section{METODOLOGIA}

Trata-se de um estudo descritivo do tipo relato de experiência resultado de vivência interdisciplinar, ocorrida no turno maturino de todas as quintas feiras compreendidas no período de fevereiro a junho de 2019, cujo vínculo pertence à disciplina intitulada: saúde e cidadania (SACI) ofertada pela Universidade Federal do Rio Grande do Norte (UFRN).

A vivência contou com a particpação de alunos oriundos dos cursos de medicina, odontologia, nutrição, enfermagem, serviço social e saúde coletiva da UFRN, que juntos, de forma interdisciplinar, formaram um grupo tutoria de atuação sob instruções da professora responsável pela disciplina, através da exploração do território e dos equipamentos sociais no bairro do panatis junto à Unidade Básica de Saúde do referido bairro na cidade de Natal/Rio Grande do Norte.

Assim sendo, algumas estratégias foram postas em prática, permitindo aos discentes, dentre outras coisas, compreender a relação entre a cidadania com os determinantes e condicionantes do processo saúdedoença, ampliar os conhecimentos sobre a dimensão comunitária do cuidado em saúde, por meio da exploração da dinâmica de funcionamento de uma Unidade Básica de Saúde dos atores e equipamentos sociais presentes, corroborando para reflexões críticas e conscientes sobre os principais problemas encontrados, e porpor intervenção. Além disso, foi possível a compreensão da importância da educação em saúde, da prática serviço-ensino-comunidade, e do favorecimento da aprendizagem quando se trabalha em equipe, através do estabelecimento de variados caminhos para se chegar a um objetico comum. Fato é que "ninguém caminha sem aprender a caminhar, sem aprender a fazer o caminho caminhando, sem aprender a refazer" (FREIRE, 1997, p. 79).

Com relação às estratégias supracitadas, no período já descrito da vivência, as mesmas serão apresentadas de forma sistematizada, em quatro momentos, que sintetizam o trabalho educacional interdisciplinar educativo vivenciado, conforme:

1‥ LEITURA E ACOLHIMENTO INICIAL: Solicitação e efetivação de leitura prévia sobre o cuidado em saúde de autoria de Maria Terezinha Gariglio, e encontro inaugural de acolhimento no auditório da reitoria da Universidade Federal do Rio Grande do Norte (UFRN). 
A leitura permitiu a compreensão sobre as seis dimensões do cuidado, e que este poderá levar à cura ou a um modo qualificado de se levar a vida; e o encontro gerou o reconhecimento do processo educacional proposto com entrega de cartilha orientadora e diálogos com foco voltado para: relação entre saúde e cidadania, determinantes sociais da saúde, educação popular em saúde e tecnologias, gestão do cuidado e trabalho em equipe, conforme registros:

Fig.1: Capa de cartilha entregue aos discentes

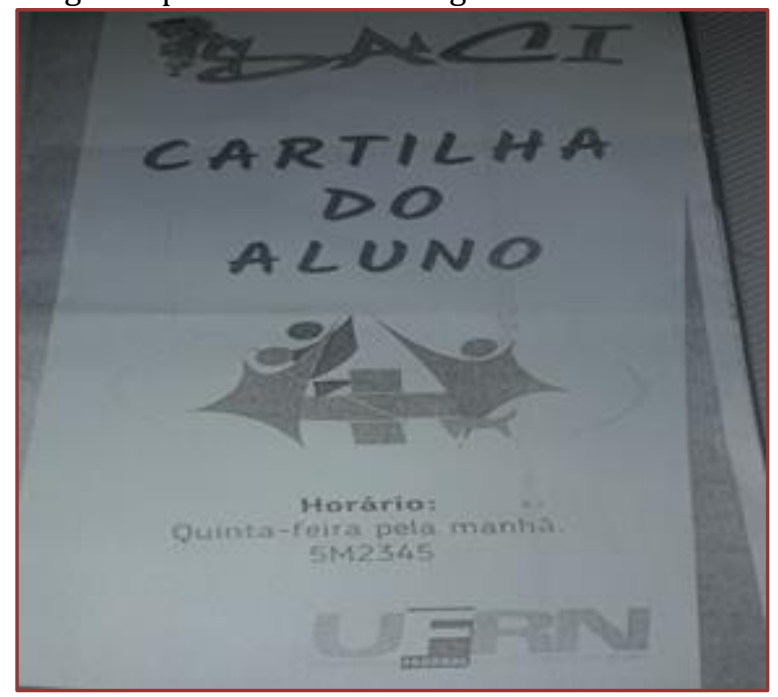

Fonte: arquivo pessoal, 2019.

Fig.2: Registro do encontro no auditório da reitoria-UFRN

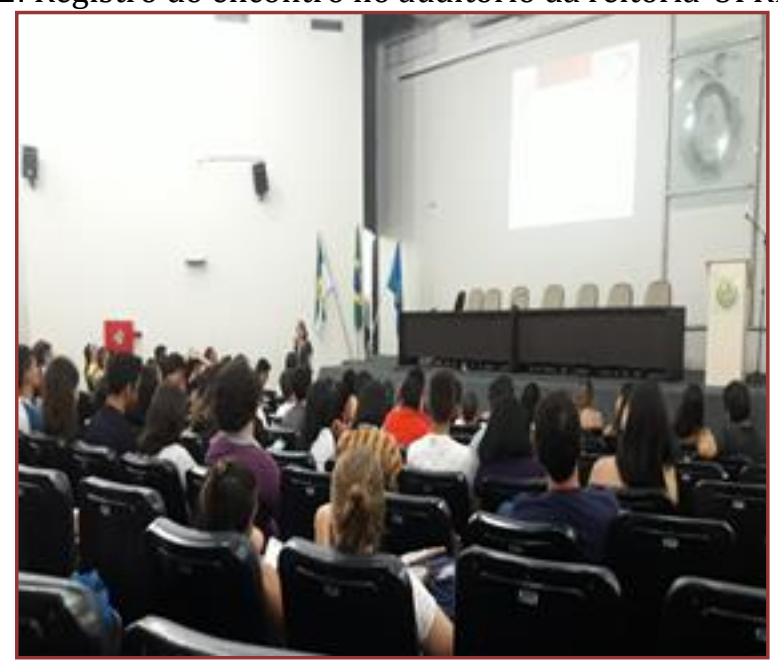

Fonte: arquivo pessoal, 2019.

2‥ MOMENTO DE PRÁTICA: Nesta etapa todos os discentes, orientados pela professora responsável conheceram a Unidade Básica de Saúde do panatis, na cidade de Natal/Rio Grande do Norte, seu mapa territorial, com divisão por cores das equipes de trabalho e suas dinâmicas. Posterioemente houve aula exploratória, com auxílio de um agente de saúde para conhecimento do bairro e de alguns equipamentos sociais de abrangência. Vale salientar que foram solicitadas leituras prévias, com destaque para o texto intitulado: Porque usar técnicas etnográficas no mapeamento, escrito por Cynthia A. Sarti. 
Fig.3: Registro de imagem própria na Unidade Básica de Saúde do Panatis

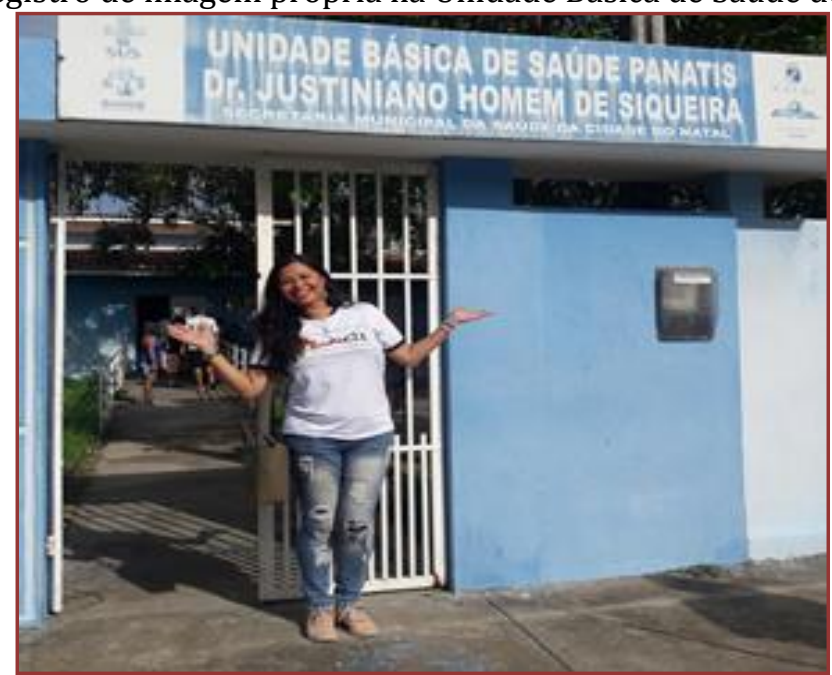

Fonte: arquivo pessoal, 2019.

Fig.4: Registro de equipamento social visitado: Centro Municipal de Educação Infantil Professora Maria Cleonice Alves Pontes

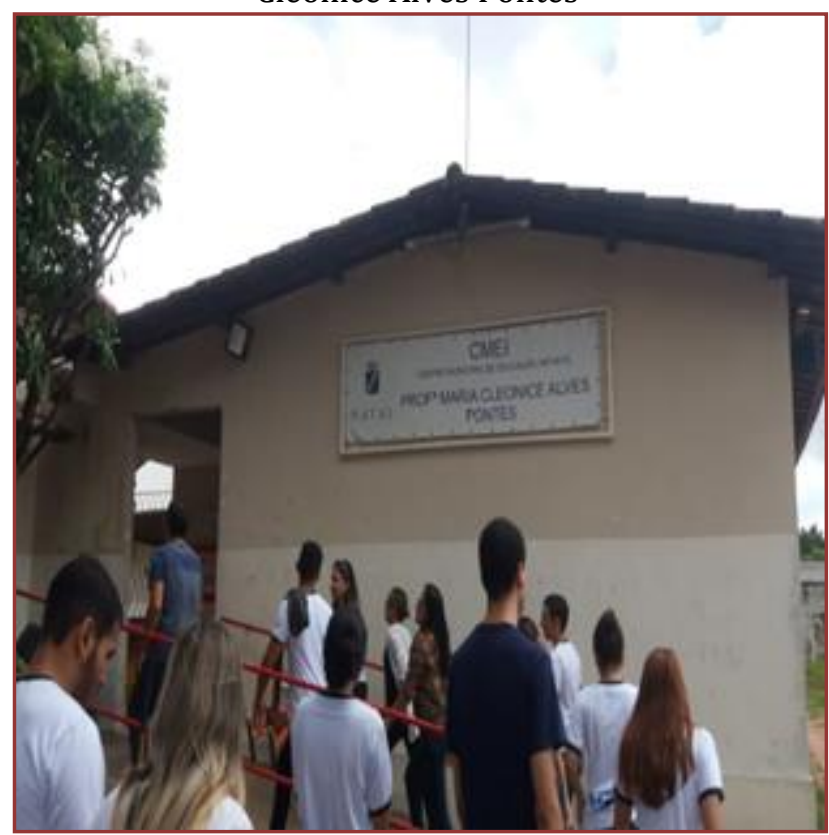

Fonte: arquivo pessoal, 2019. 
Fig.5: Registro de equipamento social visitado: Escola Estadual Professor Josino Macedo

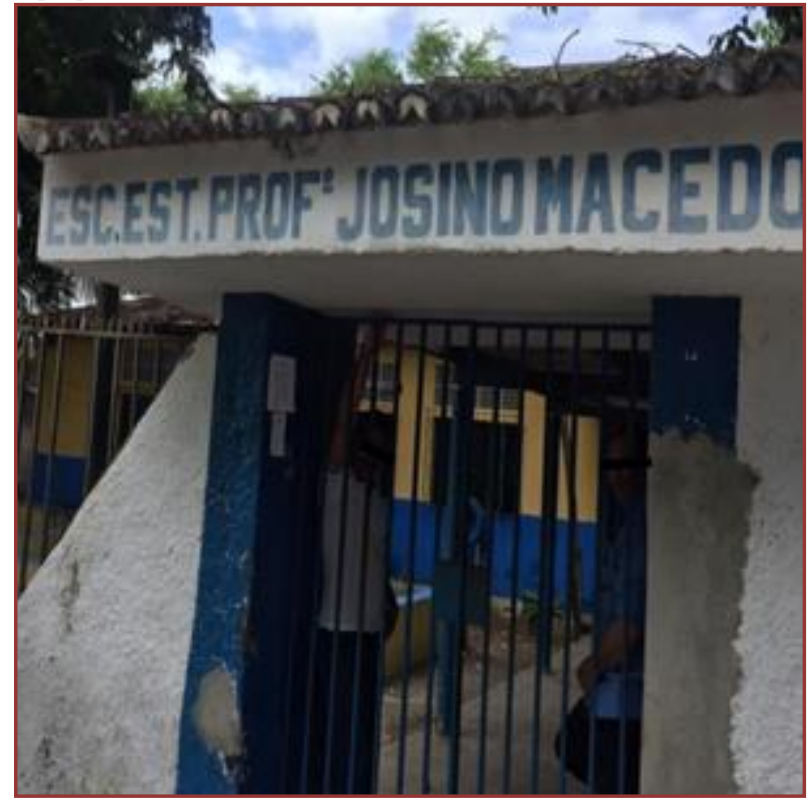

Fonte: arquivo pessoal, 2019.

Fig.6: Registro de equipamento social visitado: Escola Municipal Professora Iapissara Aguiar de Souza

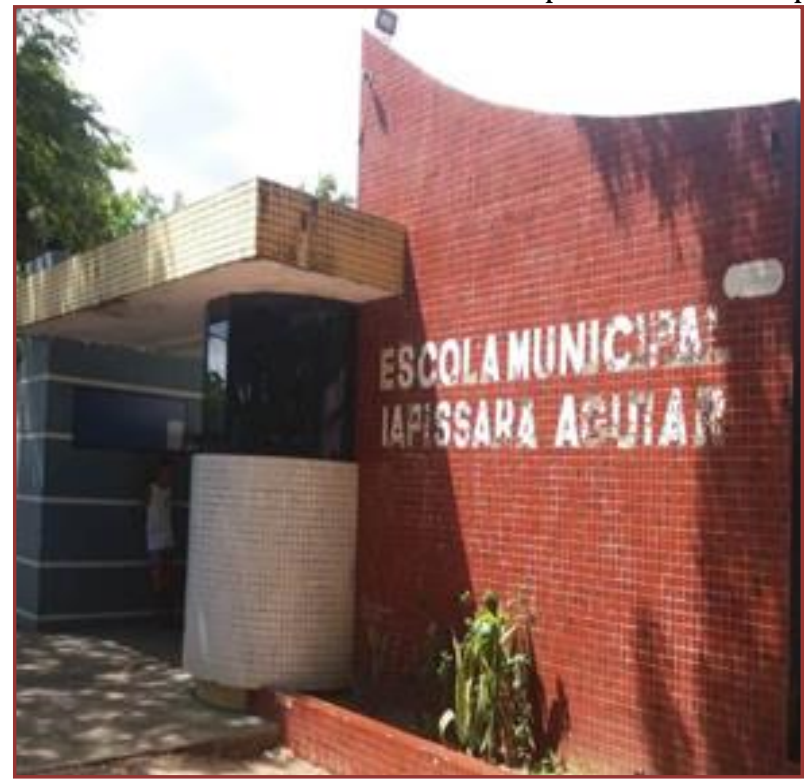

Fonte: arquivo pessoal, 2019.

3‥ RODAS DE CONVERSA: As reflexões sobre a vivência e leituras de textos solicitados como também eoncontros com profissionais de saúde da Unidade Básica de Saúde do Panatis e educadores dos equipamentos sociais visitados, eram realizados em rodas de conversa na sala de situação da referida Unidade Básica, momento em que todos eram ouvidos e estabelecidas diretrizes estratégicas a serem vivenciadas posteriormente.

4o․ INTERVENÇÕES: O grupo turorial dos disentes da disciplina planejou e promoveu intervenções relativas à culminância da vivência interdisciplinar. A primeira intervenção foi realizada na sala de situação da Unidade Básica de Saúde do Panatis, momento em que ocorreu a apresentação dos discentes e dos cursos aos quais estão vinculados à UFRN, do mapa da territorialidade na Unidade Básica, e encenação de uma peça utilizando a técnica aprendida do teatro fórum, retratando a problemática de agressão doméstica contra a mulher e vícios com drogas. Outra intervenção foi realizada no equipamento social escola Municipal Professora Iapissara Aguiar de Souza, cujo público alvo foram alunos do ensino 
fundamental II. O foco concentrou-se nos problemas identficados na referida escola relativos à saúde mental dos alunos (depressão, auto- mutilação, bullyng, suicídio e intercorrências), e na educação sexual sobre prevenção de infecções sexualmente transmissíveis e gravidez na adolescência, as estratégias utilizadas foram a roda de conversa com embasamento freiriano, dialogicidade com esclarescimento de dúvidas.

Fig.7: Registro da encenação do teatro fórum

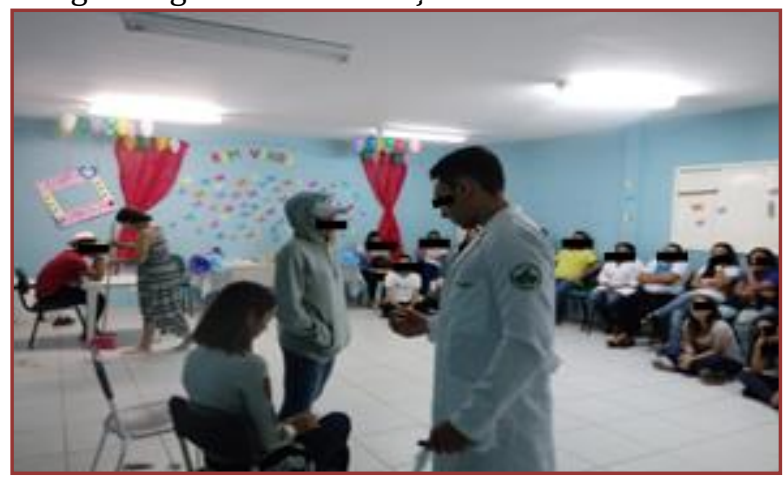

Fonte: arquivo pessoal, 2019

Fig.8: Registro da roda de conversa: intenvenção saúde mental

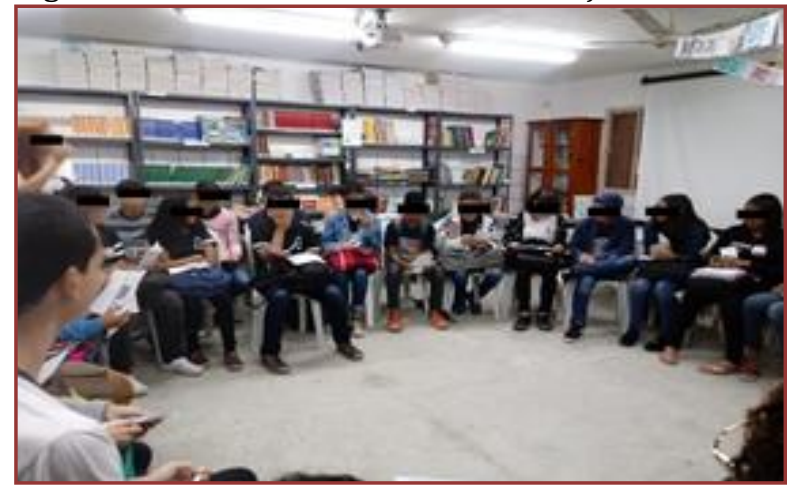

Fonte: arquivo pessoal, 2019.

\section{RESULTADOS}

Os resultados foram exitosos, enquanto prática interdisciplinar que possibilitou reflexões críticas, compartilhamento de saberes, conhecimento da dinâmica de funcionamento de uma Unidade Básica de Saúde, do seu território, equipamentos sociais de abrangência, e principais problemáticas existentes para tomada de decisões interventivas. Além disso, os vários encontros entre os aprendentes do grupo tutorial revelaram possibilidades de criação de vínculos entre discentes de diferentes graduações, e do estabelecimento de inter-relações em torno da saúde e cidadania com o meio social, corroborando, portanto, para a construção de conhecimentos.

A vivência ainda possibilitou melhor compreensão da importância de estratégias educativas para promover saúde (partindo de seu sentido ampliado), e do entendimento do conceito de cidadania (passiva e ativa) de forma consciente, na perspectiva de consolidação da democracia e dos direitos e deveres que devem ser postos em prática e respeitados.

Do ponto de vista político, a consciência é o cidadão, isto é, tanto o indivíduo situado no tecido das relações sociais, como portador de direitos e deveres, relacionando-se com a esfera pública do poder e das leis, quanto o membro de uma classe social, definido por sua situação e posição nessa classe, portador e defensor de interesses específicos de seu grupo ou de sua classe, relacionandose com a esfera pública do poder e das leis (CHAUI, 2000, p. 118). 
Dessa forma, observou-se a eficácia das estratégias propostas favorecendo o processo de ensinoaprendizagem por meio de "um trabalho de cooperação e troca, aberto ao diálogo e ao planejamento" (NOGUEIRA, 1998, p. 22).

\section{DISCUSSÃO}

Um estudo feito por Fernandes (2018), objetivou analisar a interdisciplinaridade aplicada no cotidiano escolar por meio do estudo da opinião de diversos autores. Dessa forma, foi possível identificar a necessidade de aplicação da interdisciplinaridade para melhoria da qualidade do ensino, e para ampliação da visão de mundo do educando. Dessa forma, o estudo ainda apontou que deverá ocorrer a superação do tradicionalismo pela interdisciplinaridade, uma vez que esta se apresenta como uma das soluções possíveis, que possibilita o desenvolvimento do saber crítico-reflexivo, de postura mais ética, além de melhorar o raciocínio, o senso crítico, e a assimilação e reorganização dos variados conceitos sociais; onde essa melhoria no processo educacional perpassa também pela forma como os educadores estão atuando. A promoção de mudanças significativas, ainda constitui-se um desafio, porém sua necessidade já é visualizada, na maioria das vezes, como método útil e eficaz de interação entre campos do saber.

Guimarães e Magalhães (2016), em seu estudo de revisão bibliográfica sobre a importância da interdisciplinaridade no ensino superior, expõem que existe ligação satisfatória entre a formação cultural e intelectual dos sujeitos com a aplicação da estratégia interdisciplinar. A necessidade do trabalho interdisciplinar em universidade, como forma de superação à fragmentação do saber, é relatada, nesse estudo, como forma de adaptação desse nível de ensino, que está inserido na sociedade do conhecimento, com as transformações atuais, que demandam visão integrada, contextualização de saberes e desenvolvimento do pensamento crítico. 0 estudo indica que a interdisciplinaridade na universidade é importante forma de aproximá-la à sociedade, apresentando papel dinâmico no processo ensino-aprendizagem, sendo capaz de promover necessários diálogos entre os conhecimentos, além da integração e interação dos mesmos; corroborando, além do já descrito, para o trabalho em equipe, a autonomia e pensamento crítico- reflexivo.

De modo geral, os resultados dos estudos apresentados, quando confrontados com os do presente trabalho demonstram que a interdisciplinaridade apresenta fatores positivos para o processo de ensinoaprendizagem, corroborando, dentre outras coisas, para o desenvolvimento de saberes críticos-reflexivos e compartilhamento de conhecimentos, melhorando dessa forma, a qualidade do ensino. Estabelecendose, portanto, como estratégia importante para a superação da fragmentação do saber.

\section{CONCLUSÃO}

Conclui-se que a vivência foi exitosa, enquanto facilitadora da aprendizagem, por meio do compartilhamento de conhecimentos e experiências garantidoras da aproximação de teorias com práticas sociais, colaborando de maneira eficaz com o processo formativo dos discentes envolvidos, sobretudo por possibilitar reflexões críticas e ampliação de habilidades e de conhecimentos revelados em processos interventivos nos equipamentos sociais.

Ficou estabelecido novos olhares perante a experiência vivida; olhares de gratidão pelo planejamento participativo, olhares de respeito aos princípios e valores éticos, e os que permitiram a reorganização de pensamentos quanto à importancia de modelos educativos integrativos como o apresentado.

Nesse contexto, ressalta-se a importância da continuidade de vivências educativas como a apresentada, como forma de dar prosseguimento à experiências exitosas garantidoras da qualidade necessária aos processos formativos educacionais.

\section{REFERÊNCIAS}

[1] CHAUI, M. Convite à filosofia. 12 $\underline{\text { a }}$ ed. São Paulo: Editora ática, 2000.

[2] FERNANDES, A.M.M. Interdisciplinaridade no ensino e aprendizagem: novas perspectivas e desafios na atualidade. Rev. Multidisciplinar e de Psicologia. v. 12, n. 40. 2018. Disponível em: https://idonline.emnuvens.com.br/id/article/viewFile/1048/1511. Acesso em: 30.09.20. 
[3] FREIRE, P. Pedagogia da autonomia: saberes necessários à prática educativa. 25a ed. São Paulo: Paz e Terra, 2002.

[4] FREIRE, P. Pedagogia da esperança. um reencontro com a pedagogia do oprimido. 4⿳亠丷a ed. São Paulo: Paz e Terra, 1997.

[5] GARIGLIO, M.T. O Cuidado em Saúde. In: Minas Gerais, Escola de Saúde Pública do Estado de Minas Gerais, Oficinas de qualificação de atenção primária à Saúde em Belo Horizonte, Oficina 2 - atenção centrada na pessoa. Belo Horizone: ESPMG, 2012.

[6] GUIMARÃES, P.B.; MAGALHÃES, A.P. A importância da interdisciplinaridade no ensino superior uniersitário no contexto da sociedado de conhecimento. Rev. Científica: Vozes dos Vales. UFVJM. v. 05, n.09. MG, 2016. Disponível em: http://site.ufvjm.edu.br/revistamultidisciplinar/files/2016/06/Patricia.pdf. Acesso em: 28.09.20.

[7] LUCK, H. A escola participativa: o trabalho do gestor escolar. 4. ed. Rio de Janeiro, 2000.

[8] NOGUEIRA, N.R. Interdisciplinaridade aplicada. São Paulo: Ed. Érica, 1998.

[9] PELEIAS I. R. et al. Interdisciplinaridade no ensino superior: análise da percepção de professores de controladoria em cursos de ciências contábeis na cidade de São Paulo. Campinas, Sorocaba, SP, v. 16, n. 3, p. 499-532. 2011. Disponível em: https://www.scielo.br/pdf/aval/v16n3/v16n1a02.pdf.Acesso em: 02.10.20.

[10] SANTOMÉ, J. T. Globalização e interdisciplinaridade: o currículo integrado. Porto Alegre: Artmed, 1998.

[11] SANTOS, C.M.; JÚNINOR, P.D.C. Interdisciplinaridade e educação: desafios e possibilidades frente à produção do conhecimento. Universidade Federal do Triângulo Mineiro,Uberaba, MG, 2017. Disponível em: http://seer.uftm.edu.br/revistaeletronica/index.php/revistatriangulo/article/viewFile/2672/277. Acesso em 03.10.20. 


\section{Capítulo 7}

Compreendendo a dinâmica de sala de aula a partir do número de alunos em classe: Uma análise do desempenho escolar

\section{Camila Fernanda Bassetto \\ Sebastião de Souza Lemes}

Resumo: 0 presente estudo busca proporcionar uma metodologia de análise empírica baseada nas correlações existentes entre o número médio de alunos por classe e a pontuação média alcançada no Sistema de Avaliação do Rendimento Escolar do Estado de São Paulo (SARESP). São considerados dados sobre a quantidade de alunos em sala de aula e as notas obtidas no SARESP, referentes ao período de 2008 a 2014, coletados junto ao Instituto Nacional de Estudos e Pesquisas Educacionais Anísio Teixeira (INEP) e também fornecidos pela Secretaria de Educação do Estado de São Paulo (SEE/SP). Por meio dos diagramas de dispersão construídos e dos coeficientes de correlação calculados entre as duas variáveis de interesse, foi possível observar que, no período considerado, o número médio de alunos em sala de aula influencia, ora positiva ora negativamente, a pontuação alcançada no SARESP por algumas das escolas analisadas.

Palavras-Chave: Número de Alunos. Desempenho Escolar. Análise de Correlação. SARESP. 


\section{INTRODUÇÃO}

Compreender os aspectos determinantes da qualidade educacional é uma tarefa árdua. 0 efeito do tamanho da sala de aula sobre o desempenho do aluno tem sido um tema de discussão para educadores e está no centro de debates políticos focados na qualidade educacional e na alocação de recursos. Geralmente, quando questionados sobre o número de alunos em sala de aula, pais e professores se mostram favoráveis a classes menores, talvez porque acreditam que isto favoreça o aprendizado do aluno ou porque salas reduzidas ofereçam um ambiente mais agradável para os alunos e professores que nelas estão. Embora a quantidade de alunos em classe seja considerada uma variável fácil de ser manipulada quando comparada a outros fatores escolares, a dificuldade em mensurar o efeito exercido sobre a proficiência do aluno é significativa. Embora o nível educacional varie substancialmente entre e dentro das escolas, essas diferenças são frequentemente associadas a fatores como status socioeconômico do aluno. Provavelmente por esta razão muitas pesquisas sobre a relação entre tamanho da classe e desempenho é inconclusiva.

O processo educacional no Brasil pode ser descrito como atrasado, mesmo quando comparado a países menos desenvolvidos, além de altamente assimétrico em favor de uma fatia privilegiada da população. Desde a década de 80 têm ocorrido diversas mudanças institucionais incluindo políticas educacionais para reduzir a desigualdade, expandir o acesso a escola e melhorar as taxas de alfabetização. Mas somente em meados da década de 90, após um avanço educacional muito lento comparado a outros países, causado pela elevada repetência e falta de políticas educacionais apropriadas, é que o Brasil começou a ampliar o acesso à educação de forma relativamente rápida, conseguindo aumentar significativamente a frequência escolar em todos os níveis.

O sistema educacional brasileiro é sempre avaliado e, muitas vezes, apontado como um dos fatores responsáveis pelo baixo grau de desenvolvimento do país. Na década de 1990, a avaliação educacional começou a ter um papel de destaque nas políticas públicas, na busca por melhorias dos sistemas de avaliação implantados, e também visando responder e justificar o financiamento das políticas educacionais. Nos últimos anos, é perceptível o avanço obtido na área educacional considerando os recursos metodológicos disponíveis e os atuais critérios de avaliação, tais como o Sistema Nacional de Avaliação da Educação Básica (SAEB), o Sistema de Avaliação do Rendimento Escolar do Estado de São Paulo (SARESP), o Exame Nacional do Ensino Médio (ENEM), o Exame Nacional para o Ensino, o Exame Nacional de Desempenho dos Estudantes (ENADE), entre outros.

Os sistemas de avaliação têm revelado um quadro crítico para a educação formal em relação ao desempenho e rendimento escolar do indivíduo. Para obter melhorias na qualidade do ensino e alcançar um sistema educacional eficaz, no qual o aluno aprenda, seja aprovado e conclua a educação básica dotado da capacidade de armazenar, transformar e aplicar o conhecimento, é necessário que os responsáveis pelos processos de avaliação educacional entendam, decodifiquem e interpretem, à luz da realidade, os resultados dessas avaliações, explicitando a verdadeira deficiência evidenciada pelo aluno na avaliação de suas capacidades cognitivas.

A fim de contribuir com a discussão presente na literatura referente aos efeitos do tamanho da sala sobre o desempenho do aluno, o presente estudo busca verificar a existência de correlação entre o número médio de alunos em classe e a pontuação média obtida em matemática nas últimas edições do SARESP considerando alunos da terceira série do Ensino Médio de escolas públicas de Araraquara.

O artigo está estruturado em seções incluindo esta introdução. Na seção dois apresenta-se uma breve revisão de literatura destacando estudos realizados considerando o número de alunos em sala de aula. $\mathrm{Na}$ terceira seção é realizada uma análise empírica de correlação entre as variáveis "número médio de alunos por sala" e "pontuação média no SARESP" e, finalmente, na seção quatro são apontados os resultados desta pesquisa.

\section{EFEITOS DO TAMANHO DA SALA SOBRE A PROFICIÊNCIA DO ALUNO}

O debate sobre a eficácia da redução do tamanho da classe para melhorar o desempenho do aluno tem sido surpreendentemente animado, visto o número de pesquisas realizadas. Tal debate ganhou relevância após incentivos para as reduções no tamanho da classe introduzidas na Califórnia em 1996, resultando em pressões para que o mesmo ocorresse nas escolas de todos os demais estados americanos (Hanushek, 1999). No entanto, a literatura mostra que não há um consenso acerca dos impactos da redução do tamanho da classe sobre o desempenho do aluno. Pesquisas sugerem que o tamanho da classe exerce pequenos efeitos ou atuam negativamente sobre os resultados educacionais do indivíduo. 
Na literatura, os resultados encontrados envolta dos efeitos da escola sobre o desempenho do aluno são ambíguos, conflitantes e fracos (Finn e Achilles, 1990; Angrist e Lavy, 1999; Urquiola, 2006, entre outros), evidenciando que a questão do tamanho da sala de aula continua a atrair a atenção dos formuladores de políticas educacionais e pesquisadores. Para o pessoal da escola, pequenas classes garantem facilitar o aumento da interação estudante - professor, permitem uma completa e continua avaliação do aluno, e fornecem maior flexibilidade nas estratégias de ensino. Este não é o processo somente desejado, mas também o que beneficia o estudante em risco de insucesso escolar.

Finn e Achilles (1990) descrevem um experimento de larga escala no qual alunos do jardim da infância e professores foram alocados em pequenas e grandes classes dentro de cada escola participante e os resultados mostraram que os estudantes colocados nas salas reduzidas foram beneficiados. Os autores argumentam que tais benefícios são oriundos do fato de que em classes menores a responsabilidade do professor com trabalho administrativo, tal como a manutenção de registros de alunos, é reduzida permitindo que dediquem mais tempo às atividades relevantes. Além disso, em salas de aula pequenas o professor pode manter os alunos sob olhar atento, possibilitando minimizar os problemas de disciplina entre os estudantes, e também aumentar as interações individuais, dedicando mais atenção a cada aluno. No entanto, manter classes com reduzidas quantidades de alunos custa caro e exige investimento em salários de professores e salas de aula adicionais, os quais somente são prováveis se as evidências de que os resultados são positivos forem substanciais e consistentes.

De acordo com Angrist e Lavy (1999), "the academic interest and public controversy surrounding the class size question is not only a modern phenomenon; the choice of class size has been of concern to scholars and teachers for hundreds of years" (ANGRIST E LAVY, 2001, p. 540). Baseados no fato de que o tamanho da sala de aula sobre o desempenho do aluno tem sido um tema preocupante na literatura educacional, Angrist e Lavy (1999) consideraram dados referentes a escolas israelenses para analisar a relação existente entre o número de matrículas e o tamanho da classe. Os autores utilizaram esta relação para construir variáveis instrumentais sobre os escores de testes realizados pelos alunos e, a partir dos resultados obtidos, concluíram que reduções no tamanho da sala resultam em um significante e substancial aumento no aprendizado do aluno no que se refere à leitura e à matemática. Os resultados sugerem também que os benefícios proporcionados por pequenas classes são maiores para aqueles alunos com mais dificuldades de aprendizagem.

Krueger (1999) analisou dados de estudantes e seus professores, os quais foram aleatoriamente atribuídos a diferentes tamanhos de classes. Utilizando-se de testes estatísticos, o autor concluiu que, em média, o desempenho em testes padronizados aumenta para os estudantes em pequenas turmas e que a vantagem na pontuação no teste de alunos em turmas pequenas aumenta em cerca de um ponto percentual por ano nos anos seguintes. Os resultados mostraram também que ajudantes e características de professores exercem pouco efeito sobre a proficiência do aluno e que o tamanho da classe tem um efeito maior para a minoria dos estudantes.

Urquiola (2006) apresentou duas estratégias para identificar os efeitos do tamanho da classe sobre o desempenho em escolas da Bolívia. A primeira abordagem refere-se à variação no tamanho das classes em escolas rurais com menos de 30 alunos e com somente uma sala de aula por série. Isso elimina a habilidade dessas escolas em alocar estudantes mais fracos em classes menores. A segunda abordagem explora regulações que permitem que escolas com mais de 30 alunos em uma dada série obtenham um professor adicional. Os resultados alcançados mostraram que classes maiores têm um efeito negativo sobre o desempenho dos alunos, isto é, para ambas as estratégias, salas de aula com grandes quantidades de alunos resultam em pontuações baixas nas avaliações realizadas.

Para Hanushek (2002), as evidências sugerem que qualquer efeito sobre a redução do tamanho da classe será mínimo e muito caro. Investigações mostram algum efeito do tamanho da sala sobre o desempenho para um grupo pequeno ou sob determinadas circunstâncias. $\mathrm{O}$ autor ressalta que o valor adicionado para turmas menores é praticamente nulo, exceto para os alunos que frequentam o primeiro ano de ensino, mas os efeitos estimados são insuficientes para apoiar qualquer ampliação das políticas de redução. Hanushek (2002) argumenta ainda que as políticas de redução do tamanho da classe geralmente não deixam margem para as localidades decidirem quando e onde tais reduções seriam benéficas ou prejudiciais ao desempenho do aluno.

Os resultados encontrados na literatura não dizem que reduções no tamanho da sala nunca são eficientes ou/e que nunca deveriam ser implementadas, mas que, na forma como são apresentadas no debate persistente na literatura, as propostas de redução não são suscetíveis de eficácia no que se refere ao desempenho do aluno. 
Na próxima seção é realizada uma análise empírica de correlação considerando dados sobre o tamanho da classe e a pontuação média alcançada nas últimas edições do SARESP pelos alunos da terceira série do ensino médio da rede pública estadual de ensino.

\section{ANÁLISE EMPÍRICA DE CORRELAÇÃO: TAMANHO DA CLASSE $X$ PONTUAÇÃO MÉDIA NO SARESP}

Tendo a discussão citada anteriormente como ponto de partida, o presente estudo tem por objetivo investigar a existência de uma relação entre o número médio de alunos em sala de aula e o desempenho no SARESP em escolas localizadas em um município de aproximadamente 220 mil habitantes no interior do estado de São Paulo. Para alcançar tal objetivo, uma análise empírica é realizada, a qual se constitui do cálculo das matrizes de correlação entre as variáveis "número médio de alunos em sala de aula" e "pontuação média no SARESP". Os dados utilizados, referentes a tais variáveis, têm como fonte o Instituto Nacional de Estudos e Pesquisas Educacionais Anísio Teixeira (INEP) e também a Secretaria de Educação do Estado de São Paulo (SEE-SP) no período entre 2008 e 2014.

Inicialmente, para os dados considerados no presente estudo, foram construídos os diagramas de dispersão com as variáveis "número médio de alunos em sala de aula" e "pontuação média no SARESP", os quais podem ser utilizados para determinar se existe uma correlação linear (linha reta) entre as variáveis de interesse. As Figuras de 1 a 11 contêm os diagramas de dispersão para as escolas denominadas Esc_1 a Esc_11. Todas as figuras são de elaboração própria da autora.

Figura 1. Diagrama de dispersão: Esc_1.

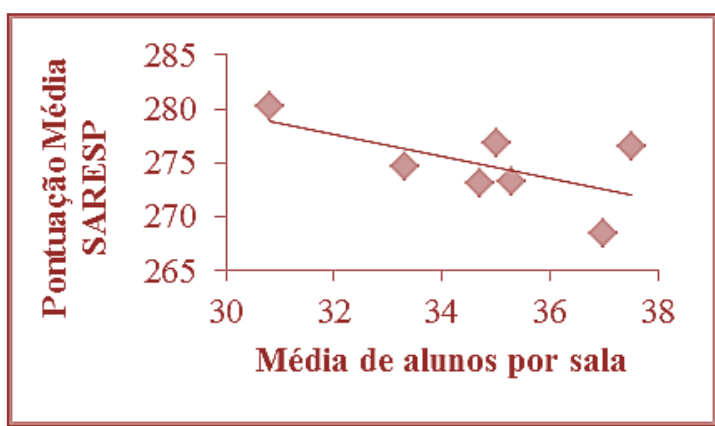

Figura 3. Diagrama de dispersão: Esc_3.

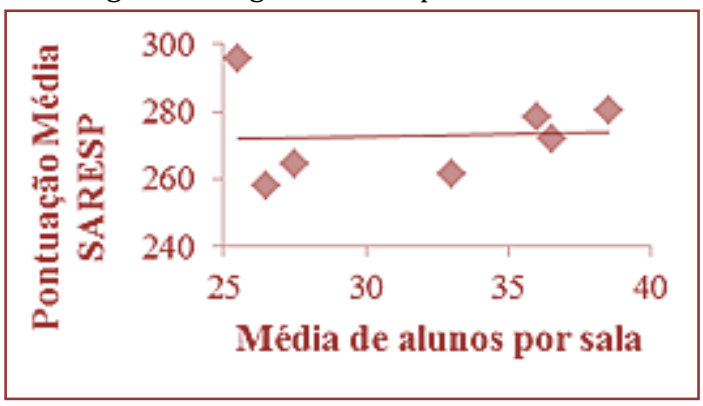

Figura 5. Diagrama de dispersão: Esc_5.

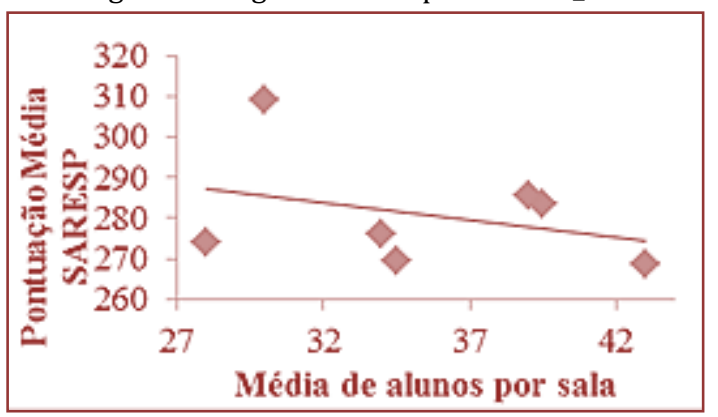

Figura 2. Diagrama de dispersão: Esc_2.

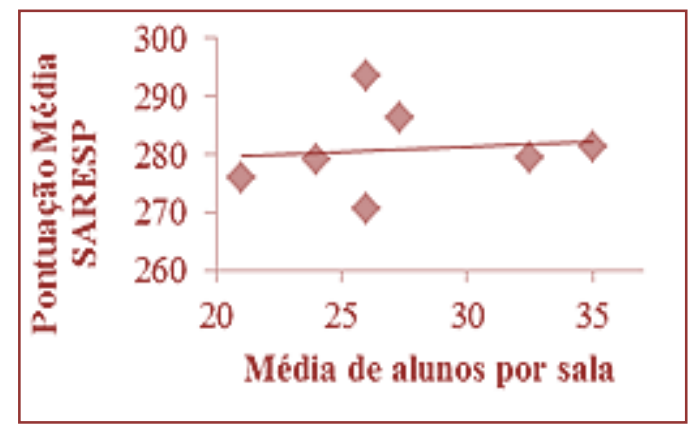

Figura 4. Diagrama de dispersão: Esc_4.

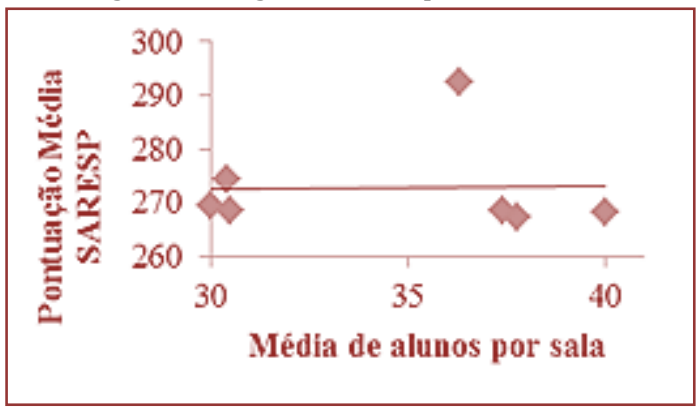

Figura 6. Diagrama de dispersão: Esc_6.

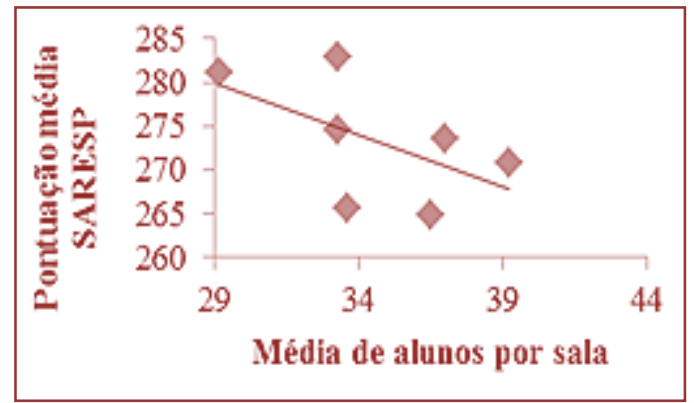


Figura 7. Diagrama de dispersão: Esc_7.

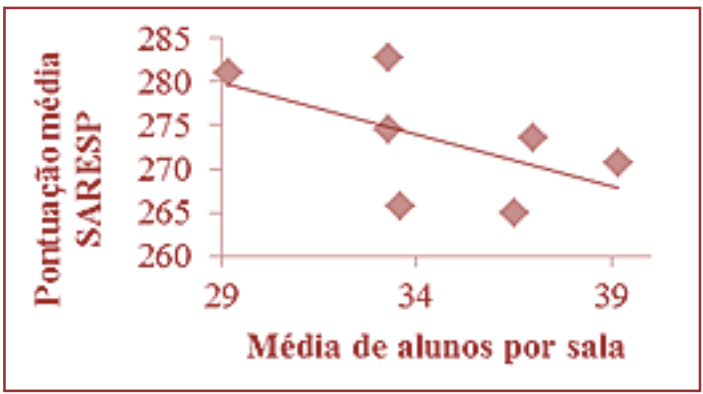

Figura 9. Diagrama de dispersão: Esc_9.

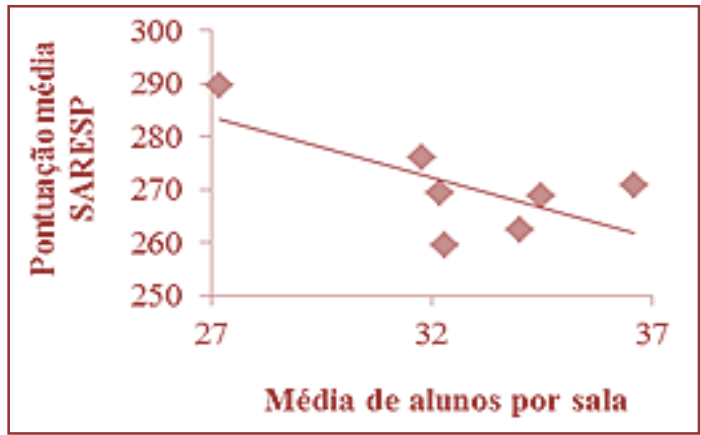

Figura 8. Diagrama de dispersão: Esc_8.

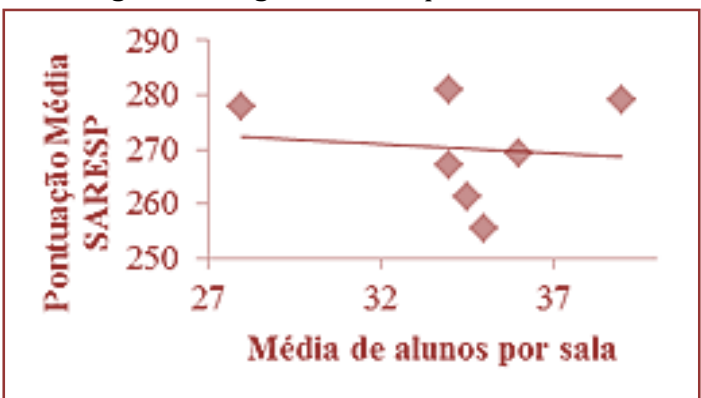

Figura 10. Diagrama de dispersão: Esc_10.

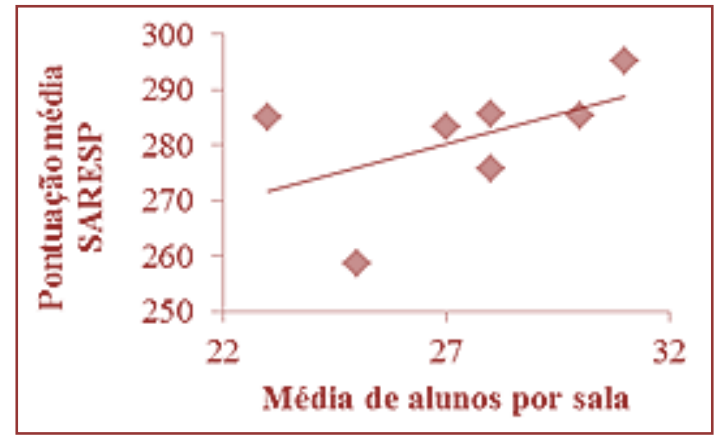

Figura 11. Correlação Escola 11

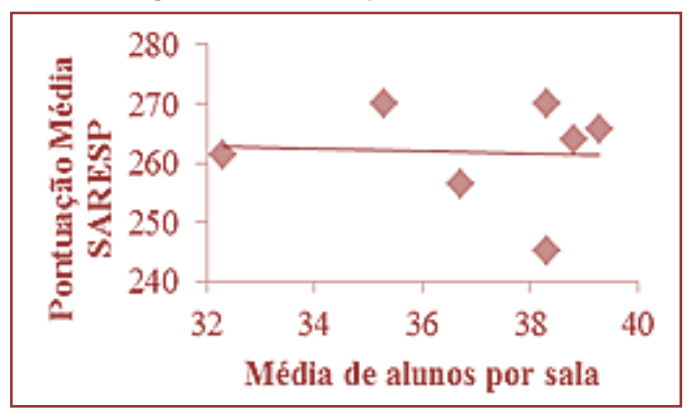

Por meio dos diagramas de dispersão apresentados para as escolas que compõem a amostra utilizada no presente estudo, pode-se observar que, enquanto os pares ordenados estabelecidos entre o número médio de alunos por sala e a pontuação média no SARESP apresentam uma tendência decrescente para as escolas Esc_1, Esc_6, Esc_7 e Esc_9, para a escola Esc_10, o comportamento desses pares ordenados é crescente e para as demais escolas não há um padrão estabelecido por esses pontos. A tendência crescente observada para as escolas Esc_1, Esc_6, Esc_7 e Esc_9 sugere que, à medida que o número de alunos por sala aumenta, a pontuação alcançada no SARESP diminui. Tal comportamento evidencia a existência de uma correlação linear de moderada a forte, porém negativa. Por outro lado, considerando a escola Esc_10, quanto maior o número de alunos por sala, mais alta será a pontuação no SARESP, sugerindo uma correlação positiva moderada ou forte. Para as demais escolas, não é possível fazer tal afirmação, pois os pontos apresentamse espalhados sem definição de um padrão crescente ou decrescente, o que significa ausência de correlação entre tais variáveis. As linhas retas traçadas pelos pontos nas Figuras de 1 a 11 permitem visualizar tais relações entre o número médio de alunos por sala e a pontuação média no SARESP. 
No entanto, afirmar que existe uma relação entre tais variáveis ou sugerir a existência de uma correlação entre ambas usando somente um diagrama de dispersão pode ser um tanto subjetivo. Uma maneira mais precisa de se medir o tipo e a força de uma correlação linear entre duas variáveis é calcular o coeficiente de correlação, representado por:

$$
\rho=\frac{n \sum x y-\left(\sum x\right)\left(\sum y\right)}{\sqrt{n \sum x^{2}-\left(\sum x\right)^{2}} \sqrt{n \sum y^{2}-\left(\sum y\right)^{2}}},
$$

onde $n$ é o número de pares de dados. A amplitude da correlação é -1 para um. Enquanto valores próximos de -1 caracterizam uma relação negativa forte, valores próximos de um mostram uma correlação positiva forte (Larson e Farber, 2010).

Os coeficientes de correlação entre o número médio de alunos por sala e a pontuação média no SARESP são mostrados na Tabela 1.

Tabela 1: Número de alunos, nota no SARESP e coeficientes de correlação entre média de alunos por sala e pontuação no SARESP.

\begin{tabular}{|c|c|c|c|c|c|c|c|c|c|}
\hline Escola & Variáveis & 2008 & 2009 & 2010 & 2011 & 2012 & 2013 & 2014 & Correlação \\
\hline \multirow{2}{*}{ Esc_1 } & № de Alunos & 37,5 & 37,0 & 35,3 & 34,7 & 33,3 & 35,0 & 30,8 & \multirow{2}{*}{$-0,62$} \\
\hline & Nota no SARESP & 276,55 & 268,46 & 273,31 & 273,12 & 274,69 & 276,9 & 280,30 & \\
\hline \multirow{2}{*}{ Esc_2 } & № de Alunos & 26,0 & 27,3 & 35,0 & 32,5 & 24,0 & 26,0 & 21,0 & \multirow{2}{*}{0,13} \\
\hline & Nota no SARESP & 293,5 & 286,22 & 281,2 & 279,25 & 279,17 & 270,5 & 276 & \\
\hline \multirow{2}{*}{ Esc_3 } & № de Alunos & 36,5 & 26,5 & 27,5 & 36 & 38,5 & 25,5 & 33 & \multirow{2}{*}{0,07} \\
\hline & Nota no SARESP & 272,03 & 257,77 & 264,55 & 278,33 & 280,45 & 295,5 & 261,4 & \\
\hline \multirow{2}{*}{ Esc_4 } & № de Alunos & 36,3 & 37,8 & 30,4 & 37,4 & 30,5 & 40,0 & 30,0 & \multirow{2}{*}{0,03} \\
\hline & Nota no SARESP & 292,49 & 267,31 & 274,28 & 268,54 & 268,46 & 268,3 & 269,5 & \\
\hline \multirow{2}{*}{ Esc_5 } & № de Alunos & 28,0 & 34,5 & 43,0 & 34,0 & 39,5 & 39,0 & 30,0 & \multirow{2}{*}{$-0,33$} \\
\hline & Nota no SARESP & 273,86 & 269,53 & 268,55 & 275,98 & 283,66 & 285,4 & 308,9 & \\
\hline \multirow{2}{*}{ Esc_6 } & № de Alunos & 33,3 & 29,2 & 36,5 & 33,3 & 37 & 33,6 & 39,2 & \multirow{2}{*}{$-0,56$} \\
\hline & Nota no SARESP & 282,83 & 281,03 & 264,86 & 274,47 & 273,53 & 265,7 & 270,7 & \\
\hline \multirow{2}{*}{ Esc_7 } & № de Alunos & 26,5 & 26,5 & 30,5 & 23,0 & 40,3 & 36,7 & 32,0 & \multirow{2}{*}{$-0,59$} \\
\hline & Nota no SARESP & 275,14 & 270,84 & 259,82 & 266,59 & 259,52 & 264 & 271,5 & \\
\hline \multirow{2}{*}{ Esc_8 } & № de Alunos & 34,0 & 36,0 & 35,0 & 28,0 & 34,5 & 39,0 & 34,0 & \multirow{2}{*}{$-0,11$} \\
\hline & Nota no SARESP & 267,06 & 269,34 & 255,34 & 277,69 & 261,15 & 279 & 280,8 & \\
\hline \multirow{2}{*}{ Esc_9 } & № de Alunos & 32,2 & 36,6 & 32,3 & 34 & 34,5 & 31,8 & 27,2 & \multirow{2}{*}{$-0,68$} \\
\hline & Nota no SARESP & 269,43 & 270,83 & 259,52 & 262,38 & 268,76 & 276,1 & 289,7 & \\
\hline \multirow{2}{*}{ Esc_10 } & № de Alunos & 28,0 & 30,0 & 23,0 & 31,0 & 28,0 & 27,0 & 25,0 & \multirow{2}{*}{0,51} \\
\hline & Nota no SARESP & 275,73 & 285,3 & 284,91 & 295,27 & 285,76 & 283,3 & 258,8 & \\
\hline \multirow{2}{*}{ Esc_11 } & № de Alunos & 38,3 & 35,3 & 36,7 & 39,3 & 38,8 & 38,3 & 32,2 & \multirow{2}{*}{$-0,06$} \\
\hline & Nota no SARESP & 270,1 & 270,08 & 256,32 & 265,63 & 264,1 & 245,3 & 261,3 & \\
\hline
\end{tabular}

Fonte: Elaboração própria a partir de dados coletados no INEP e fornecidos pela SEE-SP.

Conforme mostrado nos diagramas de dispersão e evidenciado pelos valores dos coeficientes de correlação mostrados na Tabela 1, para as escolas Esc_1, Esc_6, Esc_7 e Esc_9, há uma correlação moderada negativa entre o número médio de alunos por sala e a pontuação média obtida no SARESP, sugerindo que salas com mais alunos têm pontuação mais baixa na avaliação. 0 mesmo vale para a Esc_5, embora com uma correlação considerada fraca, Ao contrário do que foi observado para as escolas citadas anteriormente, para a Esc_10 o coeficiente de correlação igual a 0,51 sugere que salas mais reduzidas no número de alunos resultam em notas mais altas no SARESP, Para as demais escolas, os coeficientes de correlação próximos de zero evidenciam ausência de uma relação linear entre as variáveis, isto é, a pontuação média alcançada na avaliação não é influenciada pela quantidade de alunos em sala de aula. 


\section{CONSIDERAÇÕES GERAIS E FINAIS}

A questão educacional perpassa muitos aspectos, como necessidades de recursos e financiamentos, projetos político-pedagógicos, gestão e administração por parte de estados e municípios, enfim, de ações vindas das políticas públicas em sentido amplo, com suas prioridades e diretrizes. Em geral, os objetivos dos planejamentos na área educacional levam em conta as demandas da escolarização para a população em idade escolar ideal.

Medir o desempenho educacional e compreender seus determinantes são importantes para a concepção de políticas em relação a esses temas variados. Nossos estudos, nesse momento, procuram melhor compreensão de fatores que influenciam diretamente o trabalho em sala de aula e o número de alunos por turma é um desses fatores. De que forma e até onde essa componente influencia no desempenho. Em nossa amostra, as análises de correlação entre o número médio de alunos em classe e a pontuação média obtida em avaliações de matemática, não há como se fazer afirmações generalizáveis. Para assim considerarmos, analisamos os diagramas de dispersão obtidos em diferentes grupos e, pelos valores dos coeficientes de correlação mostrados, há correlações moderadas negativas entre o número médio de alunos por sala e a pontuação média obtida e há, também, correlação considerada fraca que também sugerem que salas com mais alunos têm desempenho mais baixo. Nessa amostra há também uma escola cujo resultado sugere que salas mais reduzidas no número de alunos resultam em pontuações mais altas. Há ainda alguns grupos, cujos coeficientes de correlação próximos de zero indicam a ausência de uma relação linear entre as variáveis, onde a pontuação média na avaliação não é, pela análise da correlação, influenciada pela quantidade de alunos em sala de aula.

Consideramos, nesse momento um aumento de nosso espaço amostral, para que, com maior abrangência, possamos ter mais elementos e uma base de dados mais ampla em um universo maior de estudo, isso dará uma melhor representação da realidade e mais consistência nas correlações. Sugerimos também que estudos empregando outros métodos de análises sejam realizados com finalidade de garantir a sua fidedignidade técnica. Dada a complexidade das variáveis envolvidas nesse tipo de estudo, há inúmeras controvérsias sobre a existência de um efeito contínuo sobre a correlação entre o número médio de alunos em classe e a pontuação média obtida em matemática, assim como a dimensão de sua influência, ou ainda se o mais provável é o pertencimento a grupos identificados por idade, sexo, origem étnica ou habilidades.

\section{REFERÊNCIAS}

[1] ANGRIST, Joshua D.; LAVY, Victor. Using Maimonides' Rule to Estimate the Effect of Class Size on Scholastic Achievement. Quarterly Journal of Economics, v. 114, n. 2, p. 533-575, mai/1999.

[2] FINN, Jeremy D.; ACHILLES, Charles M. Answers and Questions about Class Size: A Statewide Experiment. American Educational Research Journal, v. 27, n. 3, p. 557 - 577, jan/1990.

[3] HANUSHEK, Eric A. Some findings from an independent investigation of the Tennessee star experiment and from other investigations of class size effects. Educational Evaluation and Policy Analysis, v. 21, n. 2, p. 143-164, Summer/1999.

[4] HANUSHEK, Eric. Evidence, politics, and the class size debate. In: MISHEL, Lawrence e ROTHSTEIN, Richard. The Class Size Debate. Washington: Economic Policy Institute's Education Program, 2002.

[5] KRUEGER, Allan B. Experimental Estimates of Education Production Functions. Quarterly Journal of Economics, v. 114, n. 2, p. 497-531, mai/1999.

[6] LARSON, Ron; FARBER, Betsy. Estatística Aplicada. 4. ed. São Paulo: Prentice Hall Brasil, 2010.

[7] DAZZANI, Maria V. Avaliação Educacional: desatando e reatando nós. Salvador: EDUFBA, 2009.

[8] URQUIOLA, Miguel. Identifying Class Size Effects in Developing Countries: Evidence from Rural Bolivia. The Review of Economics and Statistics, v. 88, n. 1, p. 171 - 177, fev/2006. 


\section{Capítulo 8}

\section{Bullying na concepção de professores do Ensino Fundamental I}

\section{Dulcinéia da Silva Adorni \\ Fernanda Giselle Morais do Vale Cestari}

Resumo: A presente pesquisa tem como objetivo identificar a concepção de professores do Ensino Fundamental sobre bullying, considerando que sua prática nas escolas tem avançado nos últimos anos, tornando-se um problema endêmico. Bullying, segundo Silva (2010), refere-se a todas as formas de atitudes agressivas intencionais e repetidas que ocorrem sem motivação evidente, executadas dentro de uma relação desigual de poder. Para compreender como os educadores concebem este fenômeno, realizamos este estudo, que é de natureza qualitativa e se encontra em fase de desenvolvimento, tendo por sujeitos sete educadores do Ensino Fundamental I de uma instituição da rede particular de ensino de um município do sudoeste do Estado da Bahia. Foi aplicado um questionário com cinco questões que versavam sobre a definição de bullying, tipos, leitura sobre o tema, presenciar e/ou vivenciar ocorrências e formas de atuação na escola. Constatamos que a definição de bullying não está clara para os educadores. A maioria deles o define como atitude agressiva, deixando de destacar seu caráter intencional, a falta de motivação para as agressões, o fato de causaram dor e angústia e 0 desequilíbrio de poder entre seus personagens. Em relação aos tipos de bullying apresentaram equívocos quanto aos conceitos. Todos os educadores afirmaram já terem lido algum material sobre o tema, sendo mais recorrentes os disponíveis na internet. Apesar de a maioria deles afirmar ter presenciado ou vivenciado situações de bullying, ao relatá-las não fizeram qualquer referência à intencionalidade ou repetição das ações, como nas questões anteriores. Quanto à atuação no ambiente escolar frente a situações de bullying, destacaram algumas ações, mas não visualizaram a necessidade de pesquisar a realidade, nem a possibilidade de buscar parcerias ou formar um grupo de trabalho. Estes resultados nos levam à reflexão sobre a necessidade de maior investimento na formação continuada dos educadores para abordagem desta temática.

Palavras-chave: Bullying. Violência Escolar. Concepção de Professores. 


\section{INTRODUÇÃO}

A prática do Bullying nas escolas de todo mundo vem avançando nos últimos anos, tornando-se um problema endêmico, cuja abordagem requer urgência. Os comportamentos violentos no âmbito escolar ocorrem (ou podem ocorrer) em todos os níveis de ensino por parte dos diferentes personagens que compõem o cenário educacional institucional. Neste contexto, os alunos são os alvos mais visados, geralmente por parte de um colega ou de um grupo deles. As consequências desta prática que compreende agressões físicas e verbais, assédios e todo tipo de ações desrespeitosas ao ser humano são trágicas. A mídia não se cansa de noticiar casos de bullying que terminam em traumas físicos, psicológicos e sociais ou, nos casos mais contundentes, chegam à morte.

Entende-se por bullying todas as formas de atitudes agressivas, intencionais e repetidas, que ocorrem sem motivação evidente, adotado por um ou mais estudantes contra outro(s), causando dor e angústia, e executado dentro de uma relação desigual de poder. Atos repetidos entre iguais (estudantes) e o desequilíbrio de poder são as características essenciais, que tornam possível a intimidação da vítima (SILVA, 2010).

Diversos pesquisadores em todo o mundo têm direcionado seus estudos para esse fenômeno que toma aspectos preocupantes, tanto pelo seu crescimento, quanto por atingir faixas etárias cada vez mais baixas, relativas aos primeiros anos de escolaridade. Dados recentes apontam no sentido da sua disseminação por todas as classes sociais e uma tendência para um aumento rápido desse comportamento com o avanço da idade, da infância à adolescência. Em estudo realizado pela ABRAPIA, 40,5\% dos 5785 alunos de 5a a $8^{\underline{a}}$ séries admitiram estar diretamente envolvidos em atos agressivos na escola (LOPES NETO, MONTEIRO FILHO e SAAVEDRA, 2003).

\section{DEFINIÇÃO E BREVE HISTÓRICO DO BULLYING}

Carvalho (2007) refere que as primeiras investigações sobre bullying foram realizadas na Suécia nos anos 1970, e a partir daí o interesse se generalizou para os outros países escandinavos e outras regiões da Europa e Estados Unidos.

No início da década de 1970, o Professor Dan Olweus, da Universidade de Bergen iniciou nas escolas norueguesas, investigações sobre o problema dos agressores e suas vítimas, embora não se verificasse um interesse das instituições sobre o assunto. Na década de 1980, três rapazes, entre 10 e 14 anos, cometeram suicídio. Estes incidentes que pareciam ter sido provocados por situações graves de bullying despertaram, então, a atenção das instituições de ensino para o problema (LOPES NETO, MONTEIRO FILHO e SAAVEDRA, 2003).

Segundo os autores, Olweus pesquisou inicialmente cerca de 84.000 estudantes, 300 a 400 professores e 1.000 pais entre os vários períodos de ensino. Um fator fundamental para a pesquisa sobre a prevenção do bullying foi avaliar a sua natureza e ocorrência. Como os estudos de observação direta ou indireta são demorados, o procedimento adotado foi o uso de questionários, o que serviu para fazer a verificação das características e extensão do bullying, bem como avaliar o impacto das intervenções que já vinham sendo adotadas. Os primeiros resultados foram informados em 1989 e apontaram que um em cada sete estudantes estava envolvido em caso de bullying.

Em 1993, Olweus publicou o livro "Bullying at School" apresentando e discutindo o problema, os resultados de seu estudo, projetos de intervenção e uma relação de sinais ou sintomas que poderiam ajudar a identificar possíveis agressores e vítimas. Essa obra deu origem a uma Campanha Nacional, com o apoio do Governo Norueguês, que reduziu em cerca de $50 \%$ os casos de bullying nas escolas. Sua repercussão em outros países, como o Reino Unido, Canadá e Portugal, incentivou essas nações a desenvolverem suas próprias ações.

O programa de intervenção proposto por Olweus tinha como características principais desenvolver regras claras contra o bullying nas escolas, alcançar um envolvimento ativo por parte de professores e pais, aumentar a conscientização do problema, avançando no sentido de eliminar alguns mitos sobre esta prática violenta, e prover apoio e proteção para as vítimas. Com o sucesso da Campanha Nacional AntiBullying realizada na Noruega, diversas campanhas e estudos seguiram o mesmo caminho, dos quais podemos destacar o The DES Shefield Bullying Project-UK, a Campanha Anti-Bullying nas Escolas Portuguesas e o Programa de Educação para a Tolerância e Prevenção da Violência na Espanha, entre outros (LOPES NETO, MONTEIRO FILHO e SAAVEDRA, 2003). 
No Brasil, segundo Carvalho (2007), os estudos enfocando o bullying são mais recentes, datam da década de 1990. Dedicou-se a esse tema, em especial, a Associação Brasileira Multiprofissional de Proteção à Infância e à Adolescência (ABRAPIA) até fechar suas portas em 2007, e pesquisadores como Fante e Pedra (2008) e Silva (2010), dentre outros.

De acordo com o dicionário, bully, significa indivíduo valentão, tirano, mandão, brigão. A expressão bullying, como já destacamos acima, refere-se a um conjunto de atitudes de violência física e/ou psicológica, de caráter intencional e repetitivo, praticado por um bully (agressor) contra uma ou mais vítimas que se encontram impossibilitadas de se defender (SILVA, 2010, p.21).

A adoção universal do termo bullying foi decorrente da dificuldade em traduzi-lo para diversas línguas. Durante a realização da Conferência Internacional Online School Bullying and Violence, de maio a junho de 2005, ficou caracterizado que o amplo conceito dado à palavra bullying dificulta a identificação de um termo nativo correspondente em países como Alemanha, França, Espanha, Portugal e Brasil, entre outros dezoito (LOPES NETO, 2005).

A agressividade nas escolas é um problema universal e o bullying e a vitimização representam diferentes tipos de envolvimento em situações de violência durante a infância e adolescência. 0 bullying, segundo Lopes Neto (2005) diz respeito a uma forma de afirmação de poder interpessoal através da agressão. A vitimização ocorre quando uma pessoa é feita de receptor do comportamento agressivo de outra mais poderosa. Tanto o bullying como a vitimização têm consequências negativas imediatas e tardias sobre todos os envolvidos: agressores, vítimas e observadores.

Silva (2010) destaca algumas estratégias adotadas pelos praticantes de bullying para impor sua autoridade e manter suas vítimas sob total domínio: abuso de poder; intimidação; e, prepotência. Observase que muitas vezes estes comportamentos agressivos que ocorrem dentro das escolas são tradicionalmente admitidos como naturais, sendo habitualmente ignorados ou não valorizados, tanto por professores quanto pelos pais. Seja por uma questão circunstancial ou por uma desigualdade subjetiva de poder, por trás dessas ações há um bully que domina a maioria dos alunos de uma turma e proíbe qualquer atitude solidária em relação ao agredido.

Os "valentões" não estão somente nas escolas, podem ser encontrados em qualquer segmento da sociedade. Os bullies juvenis também crescem e serão encontrados em versões adultas ou amadurecidas (ou melhor, apodrecidas). No contexto familiar, os bullies crescidos e mais experientes podem ser identificados na figura de pais, cônjuges ou irmãos dominadores, manipuladores e perversos, capazes de destruir a saúde física e mental, e a autoestima de seus alvos prediletos. No território profissional, costumam ser chefes ou colegas tiranos, "mascarados" e impiedosos. Suas atitudes agressoras (ou transgressoras) estão configuradas na corrupção, na coação, no uso indevido do dinheiro público, na imprudência arbitrária no trânsito, na negligência com os enfermos, no abuso de poder de lideranças, no sarcasmo de quem se utiliza da "lei da esperteza", no descaso das autoridades, no prazer em ver o outro sofrer (SILVA, 2010).

O bullying tanto pode ser praticado de forma direta como indireta. Geralmente, as vítimas dos bullies são alvo de uma gama de atitudes desrespeitosas e agressivas. Silva (2010) descreve algumas formas de bullying: verbal (insultar; ofender; xingar; fazer gozações; colocar apelidos pejorativos; fazer piadas ofensivas); físico e material (bater; chutar; espancar; empurrar; ferir; beliscar; roubar, furtar ou destruir pertences da vítima; atirar objetos contra as vítimas); psicológico e moral (irritar; humilhar e ridicularizar; excluir; isolar; ignorar, desprezar ou fazer pouco caso; discriminar; aterrorizar ou ameaçar; chantagear e intimidar; tiranizar; dominar; perseguir; difamar; passar bilhetes e desenhos entre os colegas de caráter ofensivo; fazer intrigas, fofocas ou mexericos); sexual (abusar; violentar; assediar; insinuar); virtual (difundir calúnias e maledicências através da utilização de aparelhos e equipamentos de comunicação -celular e internet).

\subsection{PROTAGONISTAS DO BULLYING}

São considerados protagonistas do bullying tanto aqueles que o praticam (agressores), quanto aqueles que o sofrem (são vítimas) e aqueles que assistem (espectadores). Cada qual com seu papel e sua função dentro desta dramática realidade de agressão, medo, dor e silêncio. 
Segundo Silva (2010, p. 43), os agressores podem ser de ambos os sexos, possuem em sua personalidade traços de desrespeito e maldade e, na maioria das vezes, essas características estão associadas a um perigoso poder de liderança. Geralmente, esse poder é obtido ou legitimado através da força física ou do intenso assédio psicológico. 0 agressor pode agir sozinho, porém quando está acompanhado de "seus seguidores", seu poder de destruição é ainda maior, pois "ganha reforço exponencial, o que amplia seu território de ação e sua capacidade de produzir mais e novas vítimas". Os agressores apresentam, desde muito cedo, aversão às normas, não aceitam serem contrariados ou frustrados, geralmente estão envolvidos em atos de pequenos delitos, como furtos, roubos ou vandalismo, com destruição do patrimônio público ou privado. O desempenho escolar desses jovens costuma ser regular ou deficitário; no entanto, em hipótese alguma, isso configura uma deficiência intelectual ou de aprendizagem por parte deles. Muitos apresentam, nos estágios iniciais, rendimentos normais ou acima da média. 0 que lhes falta, de forma explícita, é afeto pelos outros. Ainda de acordo com a autora, a ausência de afetividade, ou essa afetividade deficitária (parcial ou total), podem ter origem em lares desestruturados ou no próprio temperamento do jovem. Nesse caso, as manifestações de desrespeito, ausência de culpa e remorso pelos atos cometidos, podem ser observadas desde muito cedo, por volta dos 5 a 6 anos de idade. A tendência é que essas crianças, quando crescidas, sejam capazes de cometer atrocidades cada vez maiores.

Lopes Neto, Monteiro Filho e Saavedra (2003) destacam alguns motivos para que as crianças se tornem agressores crônicos, possíveis autores de bullying: foram acostumadas a que todos façam todas as suas vontades e atendam sempre às suas ordens; gostam de experimentar a sensação de poder; tem dificuldades de relacionamento e não se sentem bem com outras crianças; sentem-se inseguras e inadequadas; sofrem intimidações ou são tratadas como "bodes expiatórios" em suas casas; já foram vítimas de algum tipo de abuso; são frequentemente humilhadas pelos adultos; vivem sob constante e intensa pressão para que tenham sucesso em suas atividades. Estas crianças precisam muito mais de ajuda que de punição a fim de este ciclo de violência que vai se instalando em suas vidas possa ser interrompido.

As vítimas de bullying são classificadas por Silva (2010) em três grupos: as típicas, as provocadoras e as agressoras.

Vítimas típicas são aqueles os alunos que apresentam pouca habilidade de socialização. Em geral são tímidos ou reservados, e não conseguem reagir aos comportamentos provadores e agressivos dirigidos contra eles. Costumam ser fisicamente mais frágeis ou então apresentam alguma "marca" que os destaca dos demais: são gordinhos ou magrinhos demais, altos ou baixos demais, usam óculos, têm alguma deficiência física, são de raça, credo, condição socioeconômica ou orientação sexual diferente etc. Enfim, apresentam alguma característica que foge ao padrão imposto por um determinado grupo e que pode deflagrar o processo de escolha da vítima do bullying - os motivos, que nunca se justificam, são sempre os mais banais possíveis.

Vítimas provocadoras são aquelas capazes de insuflar em seus colegas reações agressivas contra si mesmas. Entretanto, não conseguem responder aos revides de forma satisfatória. Em geral, discutem ou brigam quando são atacadas ou insultadas. Neste grupo encontramos crianças ou adolescentes hiperativos e/ou impulsivos e/ou imaturos, que criam, sem intenção explícita, um ambiente tenso na escola. Sem perceberem acabam "dando tiros nos próprios pés", chamando a atenção dos agressores genuínos - os quais se aproveitam dessas situações para desviarem toda a atenção para a vítima provocadora. Assim, os verdadeiros agressores continuam incógnitas em suas táticas de perseguição.

Vítimas agressoras são aquelas que reproduzem os maus tratos sofridos como forma de compensação, ou seja, procuram outra vítima, ainda mais frágil e vulnerável que ela, contra a qual comete todas as agressões sofridas.

Espectadores do bullying são aqueles que, segundo Silva (2010, p. 45) "testemunham as ações dos agressores contra as vítimas, mas não tomam qualquer atitude em relação a isso: não saem em defesa do agredido, tampouco se juntam aos agressores". A autora os divide em três grupos: passivos, ativos e neutros.

Espectadores passivos geralmente assumem essa postura por medo absoluto de se tornarem a próxima vítima. Recebem ameaças explícitas ou veladas. Apesar de não concordarem e até repelirem as atitudes dos bullies, sentem-se de mãos atadas para tomar qualquer atitude em defesa das vítimas. Silva (2010) destaca que neste grupo encontram-se aqueles que, ao presenciarem situações de bullying contra os colegas, estão propensos a sofrer consequências psíquicas, uma vez que suas estruturas psicológicas também são frágeis. 
Espectadores ativos são aqueles alunos que, apesar de não participarem ativamente dos ataques contra as vítimas, manifestam "apoio moral" aos agressores, com risadas e palavras de incentivo. Em geral, divertem-se com o que veem. Silva (2010, p. 46) ressalta que "misturados aos espectadores podemos encontrar os verdadeiros articuladores dos ataques, perfeitamente "camuflados" de bons moços. Eles tramaram tudo e, agora, estão apenas observando e se divertindo ao verem o circo pegar fogo".

Espectadores neutros são aqueles alunos que não demonstram sensibilidade pelas situações de bullying que presenciam. Em geral, são alunos que, por uma questão sociocultural (advindos de lares desestruturados ou comunidades nas quais a violência faz parte do cotidiano), são acometidos por uma espécie de "anestesia emocional". A omissão, nesses casos, também se configura como uma ação imoral e/ou criminosa, a qual alimenta a impunidade e contribui para o crescimento da violência.

Considerando que o bullying é um problema mundial, encontrado em toda e qualquer instituição escolar, seja ela de nível primário, secundário, pública ou privada, rural ou urbana e que a sua prática acarreta consequências desastrosas para suas vítimas, faz-se necessário que as escolas, urgentemente, desenvolvam ações preventivas e/ou remediativas de inibição ou enfrentamento desta problemática. A primeira condição para isso é admitir a ocorrência do problema entre nossos alunos, pois dado o contexto atual, a instituição que não a admite desconhece o problema ou se nega a enfrentá-lo.

\subsection{INTERVENÇÃO ANTI-BULLYING NA ESCOLA}

Ao propor um programa anti bullying a ser desenvolvido nas escolas, a ABRAPIA (LOPES NETO, MONTEIRO FILHO E SAAVEDRA, 2003), destaca algumas etapas a serem seguidas: (1)Pesquisar a realidade; (2) Buscar parcerias; (3)Formar um grupo de trabalho; (4)Ouvir opiniões; (5)Definir compromissos; (6)Divulgar o tema; (7)Informar aos pais.

Quando não há intervenções efetivas contra a prática do bullying no ambiente escolar, este se torna totalmente contaminado. Todos os alunos correm o risco de serem afetados negativamente, passando a experimentar sentimentos de ansiedade e medo. A adoção de medidas bem aplicadas por parte da escola e envolvendo toda a comunidade escolar, poderá contribuir significativamente para a construção de uma cultura de não violência na sociedade (LOPES NETO, MONTEIRO FILHO E SAAVEDRA, 2003).

Partindo de pressupostos desta natureza consideramos importante identificar qual o conhecimento que os professores do Ensino Fundamental I têm sobre esta temática. Neste trabalho apresentaremos os resultados obtidos com os educadores de uma instituição da rede particular de um município do sudoeste da Bahia.

\section{METODOLOGIA}

0 presente estudo é uma pesquisa de natureza qualitativa, que se encontra em fase de desenvolvimento, tendo por sujeitos os sete educadores do Ensino Fundamental I, de uma instituição da rede particular de ensino de um município do sudoeste da Bahia. 0 instrumento utilizado para a coleta de dados foi o questionário, o qual foi aplicado individualmente. Foi composto por cinco questões versando sobre a definição de bullying, tipos, leitura sobre o tema, presenciar e/ou vivenciar ocorrências e formas de atuação de enfrentamento no ambiente escolar. Segundo Bogdan \& Biklen (1994), nas pesquisas de natureza qualitativa, a fonte direta de dados é o ambiente natural, constituindo o investigador o instrumento principal. 0 pesquisador se insere em um contexto, neste caso a instituição escolar, e procura elucidar questões educativas. Ele torna-se o instrumento principal da pesquisa, pois mesmo utilizando instrumentos tecnológicos para a sua coleta são suas concepções, sensações e interpretações que guiarão os resultados. Para coletarmos dados para análise e discussão utilizamos um questionário, que é uma importante ferramenta para a pesquisa. 0 questionário, segundo Gil (1999, p.128) pode ser definido "como a técnica de investigação composta por um número mais ou menos elevado de questões apresentadas por escrito às pessoas, tendo por objetivo o conhecimento de opiniões, crenças, sentimentos, interesses, expectativas, situações vivenciadas etc.".

\section{RESULTADOS E DISCUSSÃO}

A análise dos dados obtidos nos indica que a concepção de bullying ainda não está clara para os educadores. Como podemos observar no gráfico1, a maioria deles define bullying como atitude agressiva. 
Porém, deixando de destacar outras características que são extremamente importantes para caracterizálo.

Gráfico1: Definição de Bullying

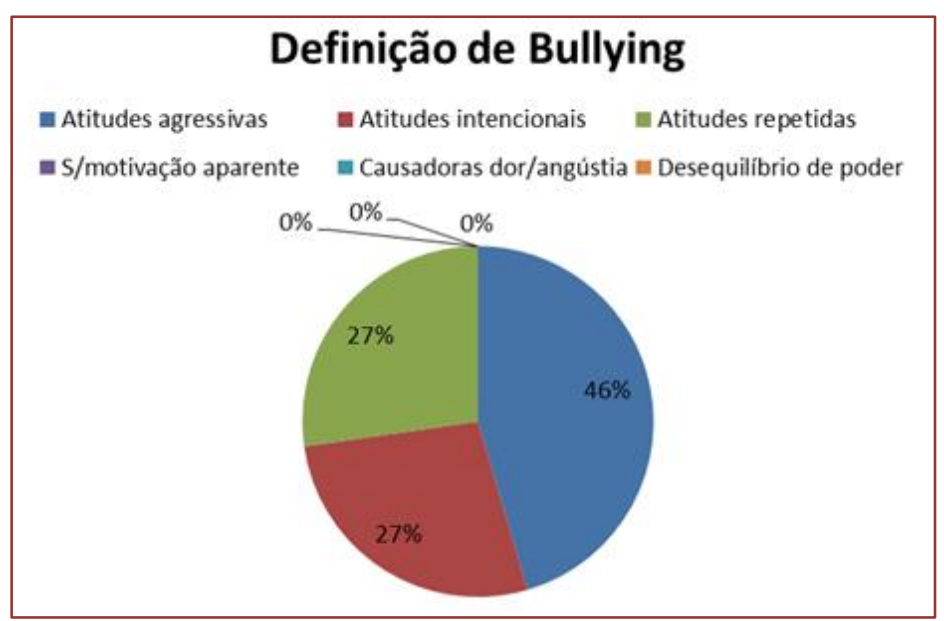

Silva (2010) afirma que além de constituir-se em atitudes agressivas, o bullying, tem um caráter intencional, repetitivo, ocorre sem motivação aparente, causa dor e angústia e é executado dentro de uma relação desigual de poder. No gráfico, observamos que $46 \%$ dos educadores definem bullying como atitude agressiva, porém apenas $27 \%$ deles destacam o caráter intencional das agressões ("São agressões intencionais, feitas de maneira repetitivas por uma ou mais pessoas contra um ou mais indivíduos"; "São agressões intencionais, verbais ou físicas, feitas repetitivamente por colegas de escola ou classe").

Um dos educadores indica a intencionalidade, mas refere-se de forma generalizada ao preconceito ("Uma forma de expressar o preconceito de maneira intencional").

Características como a falta de motivação para as agressões, o fato de causarem dor e angústia e o desequilíbrio de poder entre seus personagens, não foram citadas por nenhum dos sujeitos entrevistados. Estes resultados nos levam à constatação de que por mais que o termo bullying faça parte do vocabulário dos educadores, de um modo geral ainda é muito confuso. É usado indiscriminadamente para denominar diferentes situações no âmbito escolar ou fora dele, sem se levar em conta que existem características específicas que o definem e diferenciam de outras formas de agressões ou violência.

Quando perguntados sobre quais tipos de bullying conhecem, alguns educadores mostraram-se inseguros e apresentaram respostas equivocadas. Optamos por classificar suas respostas utilizando como categorias os tipos de bullying descritos por Silva (2010), como podemos observar no observar no gráfico2:

Gráfico2: Tipos de Bullying

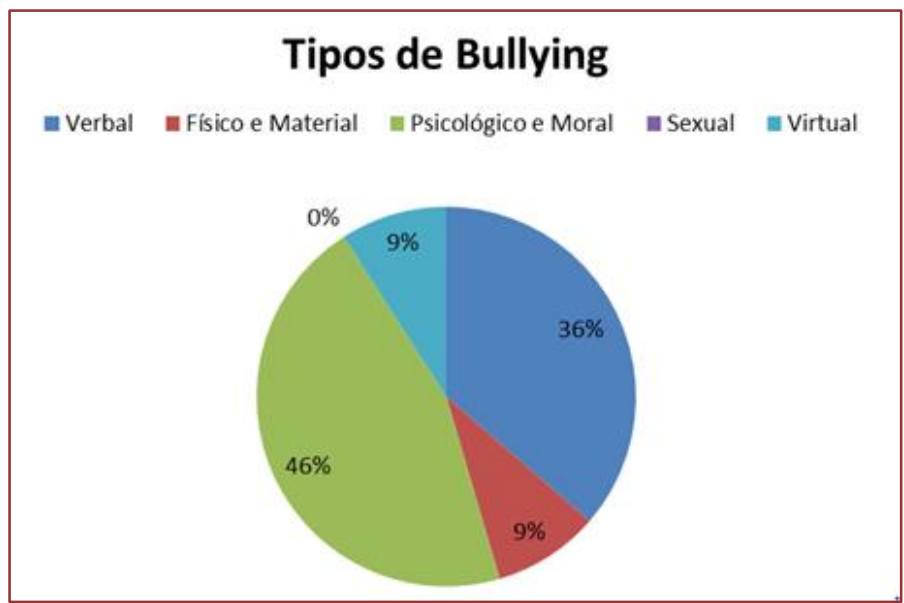


Constatamos que a maioria dos educadores destacou o bullying psicológico e moral (46\%) e o verbal (36\%). No entanto, em suas respostas fizeram referência também a outras denominações como bullying racial e social. Apresentaram equívocos na denominação do bullying físico, usando este conceito para referirem-se a características físicas da vítima e não a agressões físicas, como destacam os autores. Estes dados indicam a grande confusão que há na utilização do termo bullying por parte dos educadores e no cuidado que isso demanda, pois para abordá-lo eficazmente é preciso, em primeiro lugar, ter clareza quanto a sua definição, a fim de não banaliza-lo ou exalta-lo.

Todos os educadores afirmaram já ter lido algum tipo de material sobre o tema, sendo o mais recorrente os publicados na internet. Dois sujeitos afirmam terem lido livros sobre bullying e três fazem referência também aos noticiários jornalísticos. Observamos, portanto, que as informações estão chegando até os educadores, mas talvez não de forma sistematizada.

Perguntados se já presenciaram ou vivenciaram alguma situação de bullying, quatro dos sete educadores entrevistados (57\%) responderam afirmativamente, como mostra o gráfico 3. Destes, três relataram situações presenciadas em instituições escolares, sendo que um deles se colocou como protagonista em uma das situações quando ainda criança, no papel de vítima.

\section{Gráfico3: Situação de Bullying}

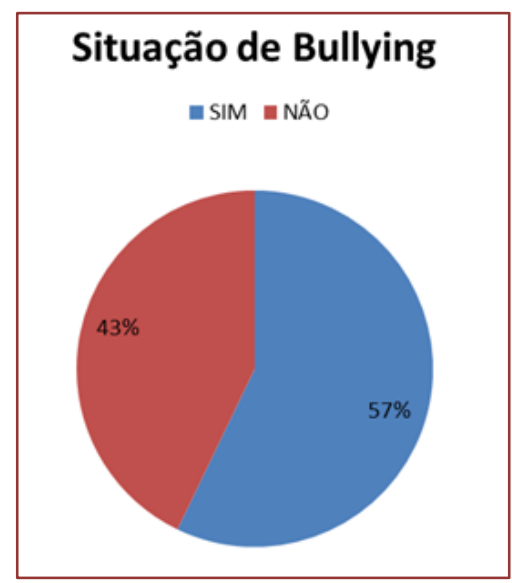

Dentre as situações relatadas pelos educadores, temos a exclusão de "um colega do grupo, por ele apresentar um problema físico", zombaria por problemas ortodônticos, agressões raciais, agressões por características físicas etc. Da mesma forma que fizeram ao definir bullying, também ao relatarem as situações não fizeram qualquer referência à intencionalidade das ações ou a repetição das mesmas. Desta forma não sabemos se de fato foram ocorrências de bullying ou ações eventuais e não repetitivas.

Foi perguntado aos educadores como podemos atuar numa situação de bullying no ambiente escolar. As respostas foram divididas em seis categorias, como podemos observar no gráfico 4 :

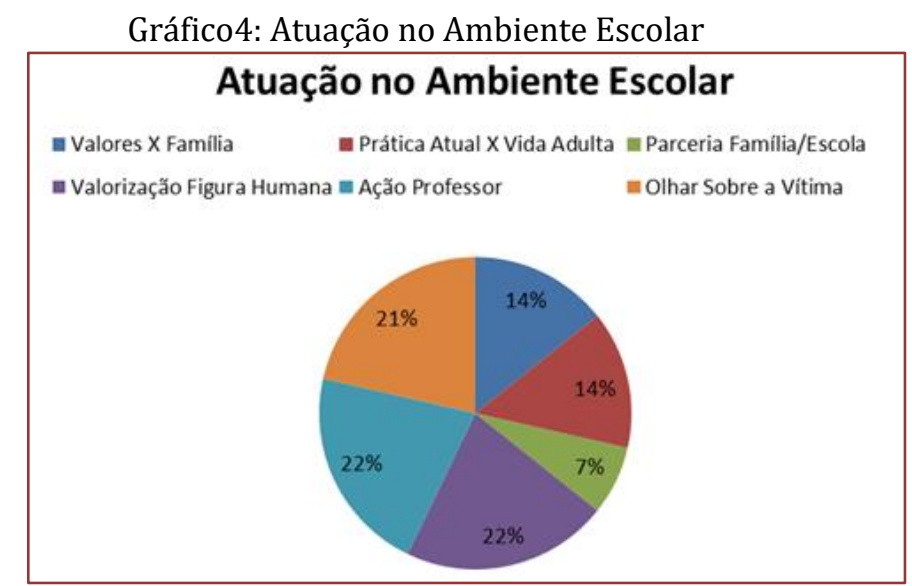


A maioria dos educadores destacou três tipos de atuação: a ação do professor, a valorização da figura humana e o "olhar" sobre a vítima. Entre os que destacaram a ação do professor, há uma diferença, no entanto, sobre como esta ação deve ser conduzida. Enquanto um educador afirma o papel da reflexão na própria ação no sentido de identificar se não está ou não contribuindo para a existência de situações de bullying ("refletir se a ação do professor indiretamente também para contribui para situação que influenciem o bullying"), outros se colocam numa postura mais neutra, como se suas ações não pudessem ter qualquer influência neste tipo de situação, focando estratégias centradas no aluno ("trabalhar com o aluno de maneira que ele entenda que o bullying não é coisa boa"). Outros educadores destacaram a importância "da valorização da figura humana" como forma de "transmitir o respeito ao outro", "mediar o ambiente para que cresça a amizade e o companheirismo" etc., mas não deixaram claro como fazer isso.

Através da categoria "olhar sobre a vítima", constatamos que os educadores só conseguiram indicar ações que visem atuar sobre o que foi agredido e não pensaram como trabalhar com o agressor, sugerindo ações como: "conversas, debates, vídeos educativos que levem-os a refletir como se sentem ao sofrer algum tipo de agressão". No entanto, todos os protagonistas do bullying precisam de atenção e tratamento, pois embora de diferentes formas todos sofrem. Como afirmam Lopes Neto, Monteiro Filho e Saavedra (2003), o ambiente escolar se torna totalmente contaminado quando não há intervenções efetivas contra a prática do bullying.

Alguns educadores estabeleceram relação direta entre a prática do bullying e suas consequências na vida adulta ("mostrar através de textos, debates e diálogos, todas as formas de bullying que existe e o mal que isso traz para quem sofre,se for criança mostrar os males para a vida adulta"). É como se o bullying só acarretasse consequências para o futuro, banalizando a situação no presente. Esses educadores parecem ter a ideia equivocada de que nas crianças o sofrimento tem menor valor, é menos agressivo, deve ser evitado em função da prevenção de um sofrimento futuro e não pelas consequências atuais. Lopes Neto (2005), é claro ao afirmar que o bullying tem consequências negativas tanto imediatas quanto tardias sobre todos os envolvidos, sejam eles agressores, vítimas e/ou espectadores.

Os entrevistados ainda trouxeram a família em duas outras situações bem características e destoantes: numa categoria que denominamos valores x família, observamos uma caraterística bastante recorrente: a dicotomia entre família e escola. Os educadores se referiram ao papel da escola na abordagem aos valores e princípios que é função da família trabalhar, mas que ela não vem dando conta ("o enfoque em temas que trabalhem e resgatem virtudes e valores que as famílias não estão dando conta de transmitir às suas crianças"). Já na categoria parceria família/escola destacaram a importância de a escola tentar estabelecer uma relação com a família para o enfrentamento das situações de bullying ("comunicar para alguém da família, para juntos família e escola tomarem as devidas providências").

As estratégias propostas pelos educadores estão em um plano bastante superficial se comparadas ao programa anti-bullying proposto pela ABRAPIA (LOPES NETO, MONTEIRO FILHO E SAAVEDRA, 2003). Os educadores não conseguiram visualizar a necessidade de pesquisar a realidade, nem a possibilidade buscar parcerias e/ou formar um grupo de trabalho. Alguns se referiram ao trabalho sistematizado, organizado, planejado, mas sempre no plano individual, o que nos leva à necessidade de uma reflexão sobre a individualização do trabalho docente e a preocupação em propor grupos de estudos que possam dar origem a grupos de trabalho nas instituições de ensino.

\section{CONSIDERAÇÕES FINAIS}

Os resultados aqui apresentados nos levam à constatação de que apesar de a temática proposta ser bastante discutida e bullying ser um termo até mesmo "corriqueiro" entre discentes, docentes e a comunidade em geral, há muitas lacunas e equívocos que precisam ser esclarecidos para melhor compreensão deste fenômeno. 0 conceito é usado de forma indiscriminada, muitas vezes banalizada, para referir-se a diversas formas de agressão, sem critérios claros e específicos. Apesar da quantidade de material que existe sobre o assunto, os educadores ainda não conseguem diferenciar bullying de outras formas de agressões ou violência escolar.

Neste sentido, identificamos a necessidade de investimento na formação contínua e continuada de todos os sujeitos envolvidos no processo educativo, a fim de instrumentalizá-los para a compreensão e abordagem desta problemática. 


\section{REFERÊNCIAS}

[1] BOGDAN, R.; BIKLEN, S. Investigação qualitativa em educação: uma introdução à teoria e aos métodos. Portugal: Porto, 1994.

[2] CARVALHO, M. P. Violência nas escolas: o "bullying" e a indisciplina. Observatório da Infância. Agosto, 2007. Disponível em: http://www.observatoriodainfancia.com.br/article.php3?id_article=233. Acesso em: 15/07/2015.

[3] FANTE, C.; PEDRA, J. A. Bullying Escolar: Perguntas e Respostas. Porto Alegre: Artmed, 2008.

[4] GIL, A. C. Métodos e técnicas de pesquisa social. São Paulo: Atlas, 1999.

[5] LOPES NETO, A. A. Bullying - comportamento agressivo entre estudantes. Jornal de Pediatria. Vol. 81, №5 (Supl), 2005.

[6] LOPES NETO, A. A., MONTEIRO FILHO, L. e SAAVEDRA, L. H. Programa de Redução do Comportamento Agressivo entre $\quad$ Estudantes. $\quad$ ABRAPIA, $2003 . \quad$ Disponível http://www.observatoriodainfancia.com.br/IMG/pdf/doc-154.pdf. Acesso em; 13/07/2015.

[7] SILVA, A. B. B. Bullying: mentes perigosas nas escolas. Rio de Janeiro: Objetiva, 2010. 


\section{Capítulo 9}

\section{Um olhar reflexivo-formativo acerca do pensamento algébrico no Ensino Fundamental}

\section{Marcos José Custódio Dias \\ José Aurimar dos Santos Angelim}

Resumo: Esse artigo resulta de uma imersão basilar em uma pesquisa doutoral, que objetiva apresentar reflexões formativas sobre situações de ensino e aprendizagem de Matemática, especificamente na perspectiva do desenvolvimento do Pensamento Algébrico no Ensino Fundamental. Muitas vezes a Álgebra ainda tem sido apresentada com ênfase nas regras de manipulação de expressões envolvendo variáveis, o que se apresenta ultrapassado, uma vez que a Álgebra é, para além do exposto, um modo de pensar, um método para reconhecer e compreender relações que produzem instrumentos possíveis de atuação social com vistas à transformação do mundo. A partir da ideia defendida, na prática, por muitos docentes de que a Álgebra é a área da Matemática que relaciona um conjunto de técnicas e símbolos, associando letras e números para fins de resoluções abstratas, parte-se da necessidade de ampliação desse conceito, que para além do apresentado, também se constitui como um método para reconhecer e compreender as relações conceituais das estruturas matemáticas. Nesse sentido, apresentamos algumas reflexões sustentadas em documentos oficiais e estudos acadêmicos sobre o ensino de Álgebra no Brasil e no exterior, com o intuito de apontar possibilidades de operacionalização do desenvolvimento do Pensamento Algébrico. Argumentamos que na formação, inicial e continuada, do professor que ensina Matemática enfatizar as interrelações entre conceitos aritméticos e geométricos pode contribuir com o rompimento da ideia reducionista de compreensão da Álgebra apenas como relações entre letras e números.

Palavras-chave: Pensamento Algébrico; Ensino Fundamental; Matemática; Formação Docente. 


\section{INTRODUÇÃO}

Lidar com a Matemática na educação básica é estar preparado para uma proposta diferenciada de ensino em Matemática (Matemática Escolar), no que diz respeito à Matemática Acadêmica trabalhada na Universidade. Todavia, essas matemáticas promovem o estudo de um ramo específico que possibilita a transformação de símbolos alfabéticos (letras) em valores numéricos. Lançar mão das ideias matemáticas abstratas em consonância com o ensino, a aprendizagem e a avaliação é associar saberes experienciais que muitas vezes estão ausentes no processo de formação do docente, dada a especificidade dessa construção[dos saberes da prática] ocorrer no contexto da inserção na sala de aula, permeado por condições distintas e variadas de realidade escolar.

Em ensino de Matemática, por exemplo, é possível verificarmos as fragmentações existentes no quesito conceitual do ensino da disciplina, ou seja, ensinar Matemática na educação básica é navegar entre Aritmética, Álgebra e Geometria, buscando apresentar aos discentes, perspectivas de uma Matemática que é complexa, porém fácil se se conhecem suas regras, preceitos, princípios, axiomas e postulados.

Entre os ramos constituintes da Matemática escolar - Aritmética, Álgebra e Geometria tradicionalmente, a Álgebra só é apresentada nas séries finais do Ensino Fundamental, especificamente, a partir do 7ํㅜ ano. Alguns pesquisadores acreditam que nas séries iniciais desse segmento, os professores (uma maioria dos professores não têm formação específica em Matemática) podem encontrar dificuldades em elaborar ou trabalhar com atividades que promovam a Álgebra, relacionando-a aos demais ramos.

Um estudo², em andamento, feito por nós, aponta que muitos professores ainda atuam fora de sua área de formação específica, o que se dá, no estado da Bahia, por uma condição empregatícia, pois os docentes são condicionados a assumirem a Matemática da educação básica de forma que não sejam considerados excedentes $^{3}$. Os que têm formação específica na área buscam estabelecer conexões válidas entre a Aritmética, a Álgebra e a Geometria de forma a não fragmentá-las, todavia a Matemática escolar trabalhada na educação básica, em especial nas séries finais do Ensino Fundamental, tem sido o centro de diversos problemas de ensino e de aprendizagem, refletidos e diagnosticados nos diversos processos de avaliação local, estadual, nacional e internacional.

A formação do professor que ensina Matemática na educação básica pode ser compreendida em dois aspectos: de um lado, uma formação na área específica, onde aos sujeitos são apresentados os conhecimentos específicos, curriculares e pedagógicos da disciplina (SHULMAN, 1998) e de outro lado, uma formação em outras áreas, nem sempre afins, mas que apresentam conhecimentos pedagógicos da disciplina, uma vez que a formação não se dá em Matemática propriamente dita.

Evidenciar o ensino de Álgebra ao longo da Educação Básica, principalmente no Ensino Fundamental, nos faz refletir sobre o que queremos e como concebemos o trabalho com essa área tão importante da Matemática. Enfatizamos no ensino sistemático de Álgebra, meramente símbolos e técnicas ou buscamos implementar variadas formas do discente pensar? Em quais perspectivas, tem sido apresentado ao discente a relação direta entre a Matemática e a Língua Portuguesa, por exemplo, no aspecto primeiro, epistemológico?

A visão mais habitual da Álgebra é que se trata simplesmente de regras de transformação de expressões (monómios, polinómios, fracções algébricas, expressões com radicais) e processos de resolução de equações. Isso é testemunhado pela terminologia dos actuais programas dos 2. o e 3.. ciclos do ensino básico que, em vez de falarem de Álgebra, falam apenas em "cálculo", ou seja, em "cálculo algébrico". Trata-se, claramente, de uma visão redutora da Álgebra, que desvaloriza muitos aspectos importantes desta área da Matemática. (PONTE, 2006, pags.10-11)

\footnotetext{
2 O Grupo GEPAFORDOC - Grupo de Estudos e Pesquisas em autoformação docente, cadastrado na CNPq, desenvolve uma pesquisa que busca cartografar o perfil dos professores que ensinam matemática na região do Piemonte Norte do Itapicuru.

3 São considerados excedentes os professores cuja carga horária não pode ser completada naquela instituição de ensino. Em muitos casos, a ele é proposta a assunção de uma outra disciplina que não seja de sua área de formação de forma a completar sua carga horária mínima para programação docente.
} 
A Álgebra ainda tem sido apresentada, em planos de ensino e na sala de aula, com ênfase nas regras de manipulação de expressões envolvendo variáveis (valores desconhecidos e muitas vezes dependentes de condições apresentadas, mas não compreendidas), o que defendemos que se apresenta ultrapassado, uma vez que a Álgebra é, para além do exposto, um modo de pensar, um método para reconhecer e compreender relações que produzem instrumentos possíveis de atuação social com vistas à transformação do mundo. Por isso, destacamos a relevância do desenvolvimento do Pensamento Algébrico como um dos aspectos de finalidade e construção merecedores do caráter primordial nos processos de ensino e de aprendizagem da Matemática nos diversos segmentos da Educação Básica, desde as Séries Iniciais do Ensino Fundamental.

\section{0 QUE DIZEM AS ORIENTAÇÕES DOCUMENTAIS}

No contexto europeu, com destaque para Portugal, a APM - Associação de Professores de Matemática, orienta, a partir do NCTM - National Council of Teachers of Mathematics, algumas condições para o desenvolvimento do pensamento algébrico e aprendizagem da Álgebra, a saber:

Compreender padrões, relações e funções; Representar e analisar situações e estruturas matemáticas usando símbolos algébricos; Usar modelos matemáticos para representar e compreender relações quantitativas; Analisar a mudança em vários contextos. (NCTM, 2007, pag. 30)

Essas condições embasam o que consideramos como competências e habilidades específicas do aluno do 8$^{\circ}$ ano do Ensino Fundamental, quando, entendemos que devem ser capazes, entre outras situações de:

Representar, analisar e generalizar padrões diversos, usando tabelas, gráficos, palavras e, quando possível, expressões simbólicas; relacionar e comparar diferentes formas de representar uma relação; identificar funções lineares e não lineares e contrastar as suas propriedades usando tabelas, gráficos ou equações; desenvolver uma primeira compreensão conceptual de diferentes utilizações das variáveis; explorar relações entre expressões simbólicas e gráficos lineares dedicando uma atenção particular ao significado de intersecção e declive; usar símbolos algébricos para representar situações e resolver problemas, sobretudo os que envolvem relações lineares; reconhecer e produzir formas equivalentes de expressões algébricas simples e resolver equações lineares; modelar e resolver problemas contextualizados usando várias representações como gráficos, tabelas e equações; usar gráficos para analisar a natureza de mudanças em quantidades em relações lineares. (NCTM, 2007, pag. 35)

É imprescindível destacar, por exemplo, que quando o docente lida com atividades consideradas de domínio básico do discente, como ordenar, classificar, agrupar, ele lida com a prática de padrões, configurando o uso do pensamento algébrico em situações formais e não-formais de ensino. 0 mesmo ocorre quando o docente lança mão do uso de relações entre figuras, objetos, imagens com situações de conceitos matemáticos, pois ele está diretamente produzindo pensamento algébrico com os discentes.

O NCTM defende que todos os discentes devem ter acesso a Álgebra desde as Séries Iniciais, pois assim, seriam incluídas oportunidades para generalizações, modelações e análises de situações, mesmo que puramente matemáticas, surgidas no mundo real, mas favorecendo aos discentes uma maneira de pensar de forma estratégica.

Já no Brasil, a Base Nacional Comum Curricular para o Ensino Fundamental (2018), na unidade temática referente a Álgebra, traz como finalidade o desenvolvimento do pensamento algébrico que visa compreender, representar e analisar situações e estruturas matemáticas.

Para esse desenvolvimento, é necessário que os alunos identifiquem regularidades e padrões de sequências numéricas e não numéricas, estabeleçam leis matemáticas que expressem a relação de interdependência entre grandezas em diferentes contextos, bem como criar, interpretar e transitar entre as diversas representações gráficas e simbólicas, para resolver problemas por meio de equações e inequações, com compreensão dos procedimentos utilizados. (BRASIL, 2018 pag. 268) 
Não muito discrepante do NCTM, a BNCC (BRASIL, 2018) também defende que o trabalho com Álgebra, especificamente no Ensino Fundamental - Séries Iniciais, seja na perspectiva de apresentação de ideias de regularidades, generalizações de padrões e propriedades da igualdade, sem propor o uso de letras para expressar essas regularidades, por mais simples que sejam. Já nas Séries Finais, um ponto bastante importante a ser considerado reside na indicação do pensamento computacional, como uma habilidade relativa a Álgebra que mantém uma estreita relação entre padrões para se estabelecer generalizações, propriedades e algoritmos.

Sobre essa relação entre pensamento computacional e Álgebra, corroboramos com a afirmação de que

[...] es una competencia básica que todo ciudadano debería conocer para desenvolverse en la sociedad digital, pero no es una habilidad "rutinaria" o "mecánica", ya que es una forma de resolver problemas de manera inteligente e imaginativa [...] además posee las características de combinar abstracción y pragmatismo, ya que se fundamenta en las matemáticas. (BERROCOSO; SANCHEZ; ARROYO, 2015, pag. 4)

Portanto, é referenciado o uso do Pensamento Algébrico também no papel de mudança e transformação de uma sociedade que vive cada vez mais num mundo digital, ou seja, conhecer a linguagem algébrica é dar condições de melhor inserção no mundo, onde o avanço tecnológico representa o processo de evolução social atual.

Para além do processo de garantia de cumprimento do currículo em Matemática, lidar com o Pensamento Algébrico estabelece relações diretas com outras áreas do saber que, historicamente, são objeto de reprodução verbal como áreas opostas à Matemática. Todavia, não se pode vivenciar um discurso equivocado dessa natureza por vivermos cada vez mais imersos numa era informatizada, onde as áreas do conhecimento se mostram interconectadas, e, a Matemática, através do Pensamento Algébrico, mostra-se fundamental no processo de construção do pensamento computacional.

\section{O PENSAMENTO ALGÉBRICO NA PRÁTICA ESCOLAR}

Ao tratarmos sobre situações que não consideram a Álgebra como apenas um conjunto de técnicas e símbolos, mas como um método para reconhecer e compreender as relações conceituais das estruturas matemáticas, necessitamos aprofundar discussões acerca das concepções sobre o Pensamento Algébrico.

Segundo Schwantes (2004, pag. 86) o Pensamento Algébrico consiste em "um pensamento que pode ser elaborado a partir do uso da linguagem cotidiana, presente em nosso dia-a-dia, ou, ainda, a partir de outras formas de linguagens". Já para Cyrino e Oliveira (2011, pag. 103), o Pensamento Algébrico compreende "um modo de descrever significados atribuídos aos objetos da álgebra, às relações existentes entre eles, à modelação, e à resolução de problemas no contexto de generalização destes objetos".

Além de existir controvérsias quanto à definição dessa terminologia, muitos pesquisadores da área de Educação Matemática, creditam nas próprias relações aritméticas um processo de compreensão das estruturas numéricas frente a elementos que necessariamente, ou tão somente, não sejam letras, mas que possibilitam reflexões algébricas, aguçando o desenvolvimento do Pensamento Algébrico.

Estabelecer conexões entre expressões numéricas, padrões geométricos, ou conteúdos basicamente aritméticos e a leitura interpretativa, fundamentalmente, construída com o domínio da Língua Portuguesa, pode ser um caminho bastante promissor para o desenvolvimento do Pensamento Algébrico, pois este começa a se desenvolver quando o discente:

estabelece relações/comparações entre expressões numéricas ou padrões geométricos (como veremos, mais adiante, na Tarefa I); percebe e tenta expressar as estruturas aritméticas de uma situação-problema; produz mais de um modelo aritmético para uma mesma situação-problema; ou, reciprocamente, produz vários significados para uma mesma expressão numérica; interpreta uma igualdade como equivalência entre duas grandezas ou entre duas expressões numéricas; transforma uma expressão aritmética em outra mais simples; desenvolve algum tipo de processo de generalização; percebe e tenta expressar regularidades ou invarianças; desenvolve/cria uma linguagem mais concisa ou sincopada ao expressar-se matematicamente... (FIORENTINI; FERNANDES; CRISTOVÃO, 2005, pag. 5) 
No contexto da Educação Básica brasileira a Álgebra e a Aritmética, permanecem tradicionalmente dispostas em sequência linear nos currículos ou se encontram, em raros pontos, convergentes no cotidiano escolar. Alguns pesquisadores, como canavarro (2007), acreditam que essa separação não deve ocorrer, pois essas duas áreas, além de possuírem estreita relação, podem favorecer de forma definitiva para o desenvolvimento do Pensamento Algébrico, dada a condição que é a Matemática a grande área composta pela Aritmética, Álgebra e Geometria.

Muito se discutiu no século XIX a respeito dessas proposições de ensino de uma Matemática Unificada como apresentava Sigurdson (1962), no entanto, o processo de compreensão da Matemática está alicerçado em preceitos, princípios e normas que estruturam o conhecimento matemático no âmbito geral. No entanto, ao docente cabe ser o estudioso que agrega valores aos elementos que associam a Álgebra, a Aritmética e a Geometria.

É relevante destacar que as relações dessas áreas da Matemática são possíveis e concretas, e, como exemplo dessa correlação, podemos afirmar que

É a partir da estrutura da Aritmética que se podem construir os aspectos sintáticos da Álgebra, o que implica analisar as expressões aritméticas não em termos do valor numérico obtido através do cálculo, mas em termos da sua forma (por exemplo, concluir que $33+8=8+33$ não porque ambos constituem 41, mas porque na adição a ordem das parcelas é indiferente). (CANAVARRO, 2007, pag. 89)

Acreditamos ser relevante no processo de operacionalização da prática docente, a partir da definição de operações matemáticas específicas, a manutenção do rigor normativo, a fim de que se efetive, por exemplo, a compreensão do uso do sinal de igualdade como uma equivalência e, não como um indicativo de uma operação que necessita ser resolvida, tão somente. Ou seja, quando o discente está diante de uma operação de igualdade, como uma equação, é preciso que ele compreenda que o símbolo " = " apresenta uma referência de valor/significado/proporção entre os membros e não de um fechamento de uma operação finita.

Sendo assim, mesmo trabalhando com Aritmética é possível apresentar aos discentes experiências em que o Pensamento Algébrico esteja presente (e também pode ocorrer trabalhando com Geometria). Como exemplo, podemos citar: atividades que enfatizem a observação de sequências numéricas, identificação de padrões numéricos, construção e interpretação de tabelas de valores, gráficos, etc., pois, ao procurar estabelecer regularidades, fazer conjecturas ou formular generalizações, mesmo que essas experiências sejam em contextos numéricos ou geométricos, possivelmente, haverá evidências do desenvolvimento do Pensamento Algébrico.

De forma geral, tanto em documentos oficiais quanto em estudos científicos, observa-se a preocupação para que o estudo da Álgebra possa explorar situações aritméticas para se chegar à formalização e generalização e, não somente chegar nestes processos com expressões meramente abstratas. Portanto, é importante não somente acreditar que os aspectos sintáticos da Álgebra podem favorecer o desenvolvimento do Pensamento Algébrico, mas também reconhecer que a Aritmética e a Geometria, quando demonstradas e correlacionadas, também se constituem em um importante caminho na direção de melhores níveis de abstração dos discentes e elevação do conhecimento matemático sistematizado.

Aparentemente, muitos discentes, têm grande dificuldade em trabalhar com letras em vez de números. A transição dos símbolos numéricos para um maior grau de abstração aparenta ser um dos grandes desafios na perspectiva dos processos de ensino, de aprendizagem e de avaliação em Matemática. Pensando dessa maneira e, admitindo que a Aritmética é, de forma intuitiva, considerada mais fácil do que a Álgebra, seria um caminho mais natural para a introdução de conceitos algébricos usando a generalização de conceitos matemáticos através de padrões numéricos, ou seja, a partir dos números dar sentido às letras (BORRALHO, 2007), mas isso não pode ocorrer despretensiosamente, ao contrário, entendemos a importância das relações de estudos e pesquisas produzidas em parceria entre a Academia e a Escola, para sucesso das aulas de Matemática na Educação Básica. 
Um outro aspecto de suma importância no desenvolvimento do Pensamento Algébrico passa pelo entendimento do conceito de variável. Um dos grandes problemas do esforço que os alunos fazem para compreender e trabalhar em Álgebra, resulta da sua limitada interpretação do termo variável (NCTM, 1991). Esse contexto, produz conflitos de apropriação de linguagens, uma vez que para o discente,

A regra muda conforme o contexto, na perspectiva do aluno, mas, do ponto de vista lógico, a regra é sempre a mesma. Esse fato mostra ao professor que a regra que ele ensina pode ter um sentido diferente para o aluno e a regra compreendida num contexto pode ser compreendida diferentemente em outro contexto. (SILVEIRA, 2008, pag. 95)

Como exemplo de apropriação do Pensamento Algébrico, podemos instituir um processo de relações e associações produzidos, a partir da ideia de correspondência biunívoca, que é apresentado ao aluno em tenra idade nas séries iniciais do Ensino Fundamental:

Fig: 01

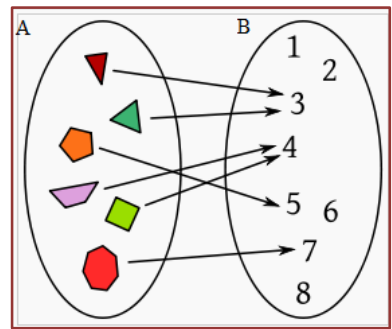

Fig: 02

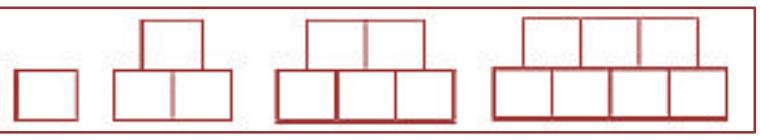

É possível verificar as leituras prováveis de ocorrência em alunos das Séries Iniciais do Ensino Fundamental, por exemplo, onde, a depender do enunciado proposto e da sua condição de leitura e interpretação, o aluno associe o Pensamento Algébrico ao visualizar por exemplo uma ideia de variável que estará condicionada às informações inferidas (cores, figuras, formas, quantidade, etc). Logo, estabelecer esse tipo de atividade pode ser um promotor do desenvolvimento do Pensamento Algébrico em crianças e jovens também.

Na Figura 2, é perceptível como a relação implícita da ideia de contagem, disposição e sequência representam elementos de pensamento algébrico. Há diversas leituras a serem feitas se fôssemos relacionar os quadriláteros e as possíveis relações variáveis entre os mesmos.

Muitos discentes conseguem realizar uma estratégia aritmética que lhe permitem determinar a solução de problemas sem, contudo, utilizar uma linguagem algébrica para resolução desses problemas. Em alguns casos, conseguem identificar e compreender a ideia de variável como um meio de exprimir uma generalização numa expressão algébrica (MATOS, 2008). Entretanto, essa talvez, não seja a regra em nossas instituições de ensino, pois a maioria dos discentes tem grande dificuldade em compreender o significado de variável e, até mesmo, sua diferença com incógnita.

Assim, é possível buscar a compreensão docente por parte das relações entre os processos de ensino e de aprendizagem em Álgebra, quando, nas circunstâncias mostradas nas figuras 1 e 2, é possível validarmos a ideia em que a linguagem e o pensamento devem estar interconectados, conforme nos assevera Vygotsky (1993).

Por exemplo, ao lidarmos com problemas contextualizados na prática cotidiana, por exemplo, no Ensino Fundamental, é possível encontrarmos a seguinte situação:

Fig: 03 
Para responder a essa questão, em primeiro momento há uma incógnita inicial configurada pelo termo "dezenas", que está presente em todas as compras de papéis feitos. Associada à ideia da quantidade de dezenas está a operação de multiplicação ou de adição, que poderia ser retratada pelo discente conforme as figuras 04 e 05 :

Fig: 04

Alex:
DEZENA: 10 UNIDADES
PAPEIS VERDES: $10+10+10+10$
PAPÉIS AMARELOS: $10+10+10$
PAPEIS AZUIS: $10+10$
Resolução: $10+10+10+10+10+10+10+10+10=90$

Fig: 05

Alex:
DEZENA: 10 UNIDADES
PAPEIS VERDES (x): 4 X 10
PAPÉIS AMARELOS(y): 3 X 10
PAPEIS AZUIS $(\mathrm{z}): 2 \mathrm{x} 10$
Resolução: $\mathrm{x}+\mathrm{y}+\mathrm{z}$
$(4 \mathrm{x} 10)+(3 \mathrm{x} 10)+(2 \mathrm{x} 10)=40+30+20=90$

As situações de resolução poderiam ser apresentadas de outras formas ainda, mas cada uma com a evolução do Pensamento algébrico que for possível desenvolver em função do processo de conhecimento matemático apresentado. No entanto, é lícito afirmar que todas elas podem representar a mesma situação algébrica em contextos evolutivos diferenciados.

Portanto, o Pensamento algébrico está presente em todo o processo educacional do aluno, desde as Séries Iniciais do Ensino Fundamental até o ensino Médio. Entretanto, é preciso romper com discursos construídos e aculturados que apresentam o 8o ano como uma série difícil por apresentar potencialmente a Álgebra aos alunos, pois a Álgebra está presente em toda a vida escolar, podendo ser compreendida a partir de ideias (matemáticas) como as ideias de regularidade, generalização de padrões e propriedades da igualdade, por exemplo, que são trabalhadas em todo o nosso processo de vida.

\section{CONSIDERAÇÕES FINAIS}

Se considerarmos os documentos oficiais, a experiência docente e a construção do conhecimento escolar, em Matemática, alcançamos uma condição, especificamente nas Séries Finais do Ensino Fundamental, onde o próprio currículo enfatiza a necessidade dos discentes em compreender os diferentes significados das variáveis numéricas em uma expressão, estabelecer uma generalização de uma propriedade, investigar a regularidade de uma sequência numérica, indicar um valor desconhecido em uma sequência algébrica e estabelecer a variação entre grandezas (BRASIL, 2018).

Ainda que vejamos índices estatísticos, oriundos, por exemplo, de avaliações externas, em larga escala, que apontem de forma negativa o conhecimento dos alunos em Matemática, é possível alcançar estruturas mais sólidas, a partir do feedback formativo em relação aos professores de Matemática e proporcionar momentos consolidados de estudos e pesquisas em torno da Matemática.

A Academia precisa se aproximar do chão da escola e vice-versa, numa comunhão de anseios e objetivos comuns que têm a ver com o processo de mudança e transformação social. 0 desenvolvimento do Pensamento Algébrico tem sido tratado, nas pesquisas brasileiras no contexto da Educação Matemática e as escolas têm recebidos esses pesquisadores, porém, é preciso ampliar as parcerias interinstitucionais, onde as fragmentações sejam ressignificadas em melhores condições formativas proporcionadas a professores, com foco no desenvolvimento profissional tanto dos professores que ensinam Matemática na educação básica.

O que apontamos, mediante nossa prática em ensino de Matemática, tanto na educação básica como na educação superior, é que

se desejamos compreender as ações dos estudantes, temos que prestar atenção ao seu solo de experiência passadas e às suas perspectivas futuras. Eles têm aspirações e esperanças. Também se sentem perdidos e abandonam tudo. Acho que é importante que a educação matemática crítica "compreenda" os estudantes, querendo dizer com isso que eles são vistos como seres humanos (grifo do autor). (SKOVSMOSE 2007, pag.236) 
Considerar o conhecimento matemático numa perspectiva da Educação Matemática é olhar o ensino de forma multirreferencial e plural, afinal não se pode ser professor de Matemática sem movimentar suas estruturas epistemológicas com suas próprias regras, axiomas e postulados, em consonância com o que conhecemos especificamente dela, associado a como conhecemos e que possibilidades relacionais são possíveis de se estabelecer numa aula de Matemática, sem perder o rigor científico que "a análise das regras matemáticas e de suas aplicações busca entender os motivos pelos quais os alunos têm dificuldades em construir conceitos matemáticos" (SILVEIRA, 2008, p. 95).

Portanto, é compreendendo que o incentivo e a devida apreciação positiva às diversas formas de representação de ideias, relações e proposições, em Matemática, garantindo a manipulação, por parte de discentes e docentes, da manipulação de variados recursos (símbolos, analogias, textos, gráficos, imagens, observações), o desenvolvimento do Pensamento Algébrico pode vir a ser um balizador da evolução da apropriação do conhecimento matemático por parte do discente.

\section{BIBLIOGRAFIA}

[1] BERRocoso, Jesús Valverde; SÁNCHEZ, María Rosa Fernández; ARROYO, María del Carmen Garrido. El pensamiento computacional y las nuevas ecologías del aprendizaje. RED-Revista de Educación a Distância, v. 46, n. 3, 2015.

[2] BORRAlho, A., CABritA, I., PALhARES, P. e VAlE, I. Os Padrões no Ensino e Aprendizagem da Álgebra. Em I. Vale, T. Pimentel, A. Barbosa, L. Fonseca, L. Santos e P. Canavarro (Orgs), Números e Álgebra (pp. 193-211). Lisboa: SEM-SPCE, 2007

[3] CANAVARRO, A.P. O pensamento algébrico na aprendizagem da Matemática nos primeiros anos. Quadrante, Lisboa, v. 16, n. 2, p. 81-118, 2007.

[4] CYRINO, M.C.C.T.; OLIVEIRA, H.M. Pensamento algébrico ao longo do Ensino Básico em Portugal. Bolema, Rio Claro (SP), v. 24, n. 38, p. 97-126, 2011.

[5] FIORENTINI, D.; FERNANDES, F. L. P.; CRISTOVÃO, E. M. Um Estudo das Potencialidades Pedagógicas das Investigações Matemáticas no Desenvolvimento do Pensamento Algébrico. In: Seminário Luso-Brasileiro de Investigações Matemáticas no Currículo. 2005. Portugal. Disponível em: https://scholar.google.com.br/scholar?hl=ptBR\&as_sdt $=0 \% 2 \mathrm{C} 5 \& \mathrm{q}=\mathrm{um}+$ estudo+das+potencialidades+pedagogicas+das+investiga $\% \mathrm{C} 3 \% \mathrm{~A} 7 \% \mathrm{C} 3 \% \mathrm{~B} 5 \mathrm{es}+\mathrm{matem} \% \mathrm{C}$ 3\%A1ticas+no+desenvolvimento+do+pensamento+alg\%C3\%A9brico\&btnG=. Acesso em: 04 de setembro de 2018.

[6] MATOS, A.; SILVESTRE, A. I.; BRANCO, N.; PONTE, J. P. Desenvolver o pensamento algébrico através de uma abordagem exploratória. In R. Luengo-González, B. Gómez-Alfonso, M. Camacho-Machín \& L. B. Nieto (Eds.) Investigación en educación matemática XII (pp. 505-516). Badajoz: SEIEM, 2008.

[7] NCTM. Principles and standards for school mathematics. Reston, VA: NCTM, 2000.

[8] NCTM. Princípios e Normas para a Matemática Escolar. (Tradução portuguesa dos Principles and Standards for School Mathematics). Lisboa: APM, 2007.

[9] PONTE, J. P. Números e Álgebra no currículo escolar. In I. Vale, T. Pimentel, A. Barbosa, L. Fonseca, L. Santos, \& A. P. Canavarro (Orgs.), Números e Álgebra na Aprendizagem da Matemática e na Formação de Professores (pp. 527). Porto: SEM/SPCE, 2006.

[10] SCHWANTES, V.; SCHWANTES, E.B.F. Uma reflexão sobre o desenvolvimento do pensamento algébrico discente no Ensino Fundamental. Varia Scientia. Volume 04, no 07, p. 77-87, agosto de 2004.

[11] SHULMAM, L. Aqueles que compreendem: o conhecimento cresce no ensino: In: Educational researcher february. Trad. GONÇALVES. O.T e GONÇALVES. V. O. T. 1986.

[12] SILVEIRA, M. R. A. O conceito em matemática e seus contextos. Educação Matemática em Revista, n. 20-21, p. 47-58, 2017.

[13] SILVEIRA, M. R. A. Aplicação e interpretação de regras matemáticas. Educação Matemática Pesquisa: Revista do Programa de Estudos Pós-Graduados em Educação Matemática, v. 10, n. 1, 2008.

[14] SKOVSMOSE, O. Educação Crítica: incerteza, matemática, responsabilidade. São Paulo: Cortez. 2007. 304 p.

[15] VYGOTSKY, L.S. Pensamento e Linguagem. São Paulo: Martins Fontes, 1993. 


\section{Capítulo 10}

\section{Lúdico: Entre o conceito e a realidade educativa}

\section{Ronara Viana Cordovil}

Virgílio Bandeira do Nascimento Filho

José Camilo Ramos de Souza

Resumo: Este artigo procura discutir o conceito de lúdico e a realidade educacional, na perspectiva de compreendê-lo como processo de ensino e aprendizagem dentro da prática educativa do professor e do educando. No contexto educacional o lúdico pode se tornar uma estratégia que auxiliará o trabalho do professor facilitando a aprendizagem dos educandos, além de se tornar um meio que promoverá a compreensão do aprendente sobre os conteúdos estudados. Para discutir foi necessário adentrar em dois universos: a primeira corresponde as concepções adquiridas nas vivências sobre o lúdico e a segunda sobre a realidade educativa; bases para a construção da compreensão e reflexão analítica do processo educativo. Foi observando e convivendo no universo escolar que instigou a realização de uma análise reflexiva, procurando deixar explícita a compreensão que o professor e os educandos possuem do processo ensino e aprendizagem, sobre o conceito e a utilização do Lúdico na sala de aula.

Palavras-chave: Lúdico. Conceito. Professor. Realidade educativa. 


\section{INTRODUÇÃO}

Este artigo apresenta reflexões analíticas a partir de diferentes autores, a fim de se chegar à compreensão do conceito de lúdico como uma estratégia de ensino dentro do campo educacional. Essa reflexão procura mostrar de que forma o lúdico pode auxiliar no ensino e no aprendizado dos educandos dentro do contexto escolar. Entende-se que o lúdico tem sempre o objetivo de facilitar a prática e o processo ensino/aprendizagem no sentido de aprofundar conhecimentos de forma prazerosa.

Para o desenvolvimento da escrita deste artigo foi realizado um levantamento bibliográfico, a qual selecionamos os seguintes autores: Cruz (2009), Silva e Mettrau (2009), Passos (2013), Santos (2011), Silva (2004), Leon (2011), Pereira (2005), Santos, Boccardo e Razera (2009), autores que discutem o lúdico e que servirá de base para as reflexões analíticas e conceituais de lúdico enquanto processo.

A leitura foi informativa e analítica na qual se procurou reconhecer as informações sobre o conceito de lúdico dentro do contexto escolar, relacionando, apontando as diferenças para finalmente analisar as afirmações oferecidas, procurando perceber a relevância e os contrapontos. Construímos sistematicamente, por meio de apontamentos e fichas, comentários, citações, resumos e observações pessoais úteis, as bases conceituais para o desenvolvimento do trabalho acadêmico, a partir do entendimento que se tinha e que se pretende ter sobre o lúdico.

As reflexões balizam a compreensão e ao mesmo tempo de forma abrangente o significado do conceito de lúdico, para assim melhor explorá-lo no espaço escolar, com questões relacionadas ao ato de ensinar embasando-se numa prática educativa inovadora visando ao ato de aprender para ensinar e ensinar para aprender. (FREIRE, 2001)

O trabalho realizado pelo professor no espaço escolar abre possibilidade de refletir sobre os procedimentos adotados no ato de ensinar; a nossa convivência e observação adquiridas dentro dessa sociedade escolar, oportunizou apresentar o lúdico como alternativa dinamizadora do ensino, onde os sujeitos da aprendizagem terão a oportunidade de experimentar procedimentos metodológicos que facilitem a compreensão de determinado conteúdo trabalhado pelo professor.

O conceito de lúdico precisa estar na pauta de reflexão diária do professor para que possa sempre apresentar alternativas de ensino inovador, para facilitar a aprendizagem do estudante, o qual poderá transformar o aprendido em novo conhecimento. Esse processo deve ser um encaminhamento contínuo para que ocorra a sociabilização dos sujeitos em diálogos escolares e científicos.

\section{REFLEXÃO SOBRE 0 CONCEITO DE LÚDICO E SEU USO EDUCACIONAL}

Ao refletirmos o conceito de lúdico em diferentes literaturas que o apresentam, percebe certas divergências na compreensão, pois alguns fazem associação do lúdico aos jogos e brincadeiras e outros o abordam como uma atividade diferente que deixa as aulas mais dinâmicas, atrativas.

Antes de pontuar e aprofundar o conceito de lúdico na visão dos teóricos é necessário buscar a definição da palavra Lúdico no Dicionário para refletir buscando divergências e semelhanças entre o que se fala e o que se escreve. Segundo o autor Sérgio Ximenes (2001, p. 549) redator e revisor do Dicionário da Língua Portuguesa, apresenta o termo: "Lúdico lú. di. co adj. Relativo a, ou que tem caráter de jogos ou divertimentos. " [Grifo do autor]. E como o ou indica alternativa, ou seja, uma opção entre as duas coisas. Pode-se deduzir que o Lúdico pode - ser tanto brincadeira que provoca divertimento por meio de alguma atividade quanto jogo, ação de jogar, disputar.

Com essa definição não fica explicito ou confirmado que lúdico é jogo e nem que é brincadeira, mas fica evidente que é uma ação ou intervenção que provoca no sujeito divertimento. Para isso, é necessário saber o que significa Jogo: "Jogo jo. go (ô) sm. 1. Ação ou efeito de jogar. 2. Atividade física ou mental, geralmente coletiva, determinada por regras que definem ganhadores e perdedores. 3. Brincadeira, passatempo. [...]." (XIMENES, 2001, p. 517). A palavra jogo leva ao entendimento de atividade desenvolvida em conjunto constituída por regras, uma competição que leva a um ganhador. Nesta perspectiva percebe-se por ser uma competição e resultar num ganhador e em um perdedor, a ideia de prazer e diversão deixa de ser válida, pois nesses casos o perdedor nunca será satisfeito. 
Sob o ponto de vista dos autores percebe-se que é feito uma associação de ambas as palavras, e, um desses autores é Passos (2013, p. 43), sustenta:

[...] termo "lúdico" é apresentado de modo incisivo: serve de adjetivo correspondente à palavra Jogo. Desse modo, ao compreendermos a remissiva temos a compreensão de jogo definida como: dispêndio de atividade física ou mental que não tem um objetivo imediatamente útil, nem sequer definido, cuja razão de ser, para a consciência daquele que a ele se entrega, é o próprio prazer que aí encontra.

Refletindo a colocação de Passos (2013), o autor imprime entendimento parecido com a definição apresentada pelo dicionário, associando a jogo realizado sem a presença de regras e esforços mentais e físicos, com objetivo apenas de promover ao participante lazer e entretenimento; na medida em que se envolve no jogo prende sua atenção e percepção promovendo assim divertimento e prazer. Vale ressaltar que essa explicação que Passos (2013) apresenta é relativa à sua pesquisa na qual tenta entender como os dispositivos informacionais mexem com a consciência das pessoas provocando assim o divertimento.

Examinando um estudo realizado em uma escola de educação infantil pela Doutora Elza Santos (2011) para entender este termo dentro da escola, temos a seguinte definição a respeito da palavra Lúdico:

[...] tem o caráter de jogo, brinquedo, brincadeira e divertimento. Brincadeira refere-se basicamente à ação de brincar, à espontaneidade de uma atividade não-estruturada; brinquedo é utilizado para designar o sentido de objeto de brincar, jogo é compreendido como brincadeira que envolve regras e, divertimento como um entretenimento ou distração. (2011, p. 24).

Mesmo em espaços e pesquisas diferentes, a definição de lúdico permanece associada a jogo, a diferença está na estrutura do jogo com e sem regras, com refere-se à competição, disputa, requer habilidades mentais e físicas e, sem a brincadeiras, diversão, espontaneidade. Santos (2011) expõe com clareza a definição de jogo e acrescenta outros termos a esta ação cujo pretexto é entreter e divertir, são os atos de brincar e a brincadeira. Este último tem o seguinte significado: "Brincadeira brin.ca.dei.ra $s f$. 1. Ação ou efeito de brincar. 2. Divertimento, especialmente de criança. 3. Gracejo. 4. Zombaria. 5. Recreação, entretenimento. " (XIMENES, 2001, p. 139). São ações espontâneas que parte das próprias crianças em seus momentos de lazer, criarem brincadeiras, se movimentarem para distrair, passar o tempo, divertirse.

Observando o pensamento de Leon (2011, p. 14), verifica-se outra visão de lúdico no aspecto educacional, com intuito de auxiliar o processo de ensino-aprendizagem, reforça "o lúdico é um mecanismo estratégico de desenvolvimento da aprendizagem, pois propicia o envolvimento do sujeito aprendente e possibilita a apropriação significativa do conhecimento". Com esta definição Leon (2011) defende o lúdico com objetivo diferente, de ensinar e aprender, levando aos educadores a proposta de diversificar sua prática pedagógica proporcionando aos estudantes atividades diferentes.

Apesar de sempre encontrarmos a palavra jogo e lúdico juntos, no meio escolar é mais do que apenas um divertimento por meio do jogo, é um aprendizado construído com o agir e interagir na relação do objeto com o ser. É "uma proposta, aparentemente atraente e inovadora, possibilita atender satisfatoriamente essa exigência. [...] Aprendizado de modo lúdico, ou seja, permitem que o estudante aprenda se divertindo". (CRUZ, 2009, p. 4).

Da mesma forma, defende Santos, Boccardo e Razera (2009, p. 01) ao afirmarem:

Diversas experiências difundidas na literatura, ao longo desses últimos anos, têm mostrado a validade dos aspectos lúdicos na aprendizagem dos alunos. $\mathrm{E}$ não são poucos os educadores que têm afirmado ser a ludicidade uma importante alavanca da educação para o terceiro milênio.

Neste mesmo sentido, Silva e Mettrau (2009, p. 3) inferem a respeito de atividades lúdicas como sendo de "um caráter motivador, por exemplo, tem em vista despertar o interesse do indivíduo/estudante e implica envolve-lo em algo que tenha significado para si. É necessário que se sinta seduzido pelo que lhe é apresentado". Aprende-se divertindo por meio de jogos planejados e estruturados para levar aos estudantes conteúdos científicos, de forma mais leve e interessante a percepção dos aprendentes. 
As divergências entre os autores deixa claro a diferença entre ludicidade presente no jogo usado para distração e a utilização do jogo de forma lúdica como um recurso didático para ensinar. E, ao mesmo tempo em que ensina leva ao aprender de forma prazerosa, atraente com atividades didáticas diferenciadas (recurso didático), diverte por meio do brincar através de um jogo.

O lúdico no ambiente escolar é um recurso didático que torna mais interessante o espaço (local) e o aprendizado dos estudantes, levando-os a seu desenvolvimento referente ao ensino aprendizagem com aulas mais envolventes e significativas para os estudantes, "por meio dos diferentes tipos de atividades, os alunos terão a oportunidade de explorar situaç̧ões, sejam elas reais ou imaginárias que possibilitarão a assimilação e fixação do conhecimento. " (CRUZ, 2009, p. 2).

\section{LÚDICO E A REALIDADE EDUCACIONAL COMO PROCESSO DE APRENDIZAGEM}

Ao relacionar não somente o conceito, mas também sua execução na prática educativa, percebe-se que há certo distanciamento no fazer aulas lúdicas nas aulas, as quais vêm descritas nos argumentos dos autores, que apresentam o lúdico como jogos utilizados para distrair os educandos e outros para ensinar de forma dinâmica.

Nas reflexões emitidas nas concepções dos autores é apresentado dois caminhos para o professor, o primeiro utilizar o jogo para distrair os estudantes de uma atividade mais pesada e puxada, e, a segunda é utilizá-lo com o intuito de ensinar conteúdos, incorporando um sentido mais plausível com finalidade de auxiliar no ato de ensinar e aprender de forma satisfatória, que está além de provocar distração ou diversão.

Às vezes o primeiro sentido prevalece na sala de aula, se efetivando de maneira hegemônica, não contribuindo para que o estudante construa conhecimento, referente a isso, Cruz faz uma crítica:

A questão [...] é em relação ao uso indiscriminado e exclusivo desta prática nas salas de aula que, efetivamente, não possibilita ao estudante a correta interpretação dos fatos, fenômenos e processos naturais, bem como estabelecer relações com situações de seu cotidiano. (2009, p. 2)

O jogo pelo jogo dentro da sala de aula, sem objetivo definido, não é válido, pois não possibilita a construção, a associação, a organização de conhecimentos necessários para o estudante trabalhar e relacionar com os conteúdos de sua vivência. Santos, argumenta que:

[...] o jogo não tem valor educativo em si mesmo, e sim o seu uso. [...] Ele poderá contribuir no sentido de permitir um relaxamento necessário a outros esforços intelectuais, tornar lúdicos exercícios didáticos tais como ler e escrever e, ainda, ser suporte para a compreensão da personalidade da criança e para atividades físicas, incluindo também a educação para o corpo. (2011, p. 48)

O lúdico é um modo de entreter os educandos em alguns casos, quando se quer descansá-los de alguma atividade ou conteúdo classificado como enfadonho, cansativo, pode ser uma alternativa para distrair, ou uma válvula de escape para "a falta de atenção ou a incapacidade de concentrar-se por mais tempo em determinada situação é uma queixa muito comum da atualidade". (LEON, 2011, p. 14). Os jogos diversos podem ser utilizados com este objetivo de entreter os educandos, enquanto descansam, mas a reflexão analítica aqui traçada tem interesse em conhecer e articular ações, objetivos que promova a aprendizagem de conteúdos escolares através do lúdico com atividades diferenciadas.

O uso do lúdico com objetivo definido, já direcionado para o que ser quer atingir, torna-se uma importante estratégia para ensinar, fixar ou mesmo aprender conceitos, conteúdos e experienciar situações, chegando assim, ao verdadeiro sentido do Lúdico. Pode ser através de jogos, brincadeiras, porque tudo isso tem fundamento e faz parte do ato de ensinar, o professor também deve brincar com os seus estudantes. Pereira (2005) sustenta que:

[...] a importância de viver o brincar como possibilidade de incorporação do lúdico á prática docente, na medida em que "quanto mais o adulto vivenciar sua ludicidade, maior será a chance de este profissional trabalhar com a criança de forma prazerosa. (p. 77).

0 adulto (professor) também precisa estar apto a moldar sua prática, precisa aceitar mudar, reconhecer, conhecer os pontos positivos e negativos da sua atuação. E aperfeiçoar-se para assim intervir e agir da melhor maneira possível, visando o bem estar e o que os estudantes podem aprender. 
Apesar de haver conflito com os teóricos entre os conceitos: lúdico, brincadeira e jogo, os educadores precisam estar cientes quanto a sua utilização, e estar sempre atentos quando associá-los a seu principal interesse: a aprendizagem dos seus educandos, ou seja, devem estar muito bem articulados.

Envolver conteúdos nas brincadeiras, nos jogos, com intuito de ensinar exige bastante conhecimento e habilidade dos educadores, pois "é necessário que se sintam seduzidos pelo que lhes é apresentado, que encontrem significação a partir das atividades desenvolvidas, para que possam compreender os enunciados científicos e a construção da própria ciência". (SILVA, 2004, p. 4).

Toda criança por natureza gosta de se movimentar, brincar, manusear objetos, ou seja, é curiosa, observadora. Cabe ao professor usar isto a seu favor, pois, “[...] o próprio exercitar do ser criança, que exercer o direito a ser irrequieto, curioso, questionador, alegre, matreiro". (PEREIRA, 2005, p. 84). Conhecer os educandos é fundamental, principalmente, para propor atividades diferenciadas para ensinalhes de outra maneira.

O lúdico na realidade educacional seguido de um bom objetivo e boas referências para que a aprendizagem seja alcançada, interessando e chamando os estudantes a construir seu próprio saber; o conhecimento torna-se um recurso didático direcionado ao êxito. Para isso, Santos, Boccardo e Razera (2009, p. 03), enfatizam:

[...] a importância do planejamento e da intencionalidade - aspectos que subjazem aos aspectos lúdicos no processo de ensino escolar - e, ainda sobre os cuidados dos perigos advindos do caráter competitivo que certos jogos ou brincadeiras incitam. Os objetivos educacionais sobressaem o tempo todo.

0 professor deve ter todo cuidado ao direcionar sua prática com base numa proposta lúdica, pois ao fazer isso, "ao inserir o Lúdico na rotina escolar, o professor assume o papel de organizador e condutor da aprendizagem ao invés de apenas comunicador de conhecimentos". (CRUZ, 2009, p. 5). 0 professor tem a responsabilidade de planejar e organizar bem as atividades e os conteúdos para que o estudante se sinta parte e participe ativamente.

\section{CONSIDERAÇÕES FINAIS}

Diante das diferentes concepções em torno do conceito de Lúdico, compreende-se que ainda há muitas interrogações para concluir e chegar ao verdadeiro conceito. E, uma das causas dessa dificuldade de compreensão pode estar ligada às palavras ou ao termo Lúdico que são: Jogos e Brincadeiras.

Essa associação entre palavras é realizada porque ao refletimos sobre a ação e o sentimento que os jogos e as brincadeiras provocam, percebe-se certa similaridade no que eles provocam: o desenvolvimento da comunicação, atenção, divertimento e prazer. Por isso, que alguns teóricos chegam a essa conclusão do Lúdico.

Atividades diferenciadas também podem provocar estes sentimentos, dependendo da forma como trazem os conteúdos (exercícios, leitura, interpretação, resolução de problemas e outros) como são manipulados proporcionando ao educando um desenvolvimento intelectual.

Os jogos geralmente são utilizados separados de conteúdos, muitas vezes é uma forma de chamar a atenção dos educandos dispersos em sala de aula, assim, entende-se que há uma dissociação do conceito do lúdico. 0 jogo ou a brincadeira dessa forma perde o sentido de ludicidade e se limita numa atuação que atinge em partes os objetivos educacionais.

O lúdico como um recurso didático, está além de ser apenas jogos e brincadeiras, de propor divertimento, suas características são bem mais acentuadas como: desenvolver habilidades motoras e intelectuais, fixar conteúdos de forma prazerosa e envolvente, permitindo assim ao educando construir sua aprendizagem. 


\section{REFERÊNCIAS}

[1] CRUZ, Jonierson de A. da. O lúdico como estratégia didática: investigando uma proposta para o ensino de física. In: SIMPÓSIO NACIONAL DE ENSINO DE FÍSICA - SNEF, 18., 2009 - Vitória, Es. Anais... Vitória, Es. 2009. p. 1-8.

[2] FREIRE, Paulo. Pedagogia da Esperança. 8ª ed. São Paulo: Paz e Terra, 2001.

[3] FUNARO, Vânia M. B. de O. (coordenadora). et al. Diretrizes para apresentação de dissertações e teses da USP: documento eletrônico e impresso Parte I (ABNT) / Sistema Integrado de Bibliotecas da USP. Universidade de São Paulo. Sistema Integrado de Bibliotecas da USP. 2. ed. rev. ampl. São Paulo: Sistema Integrado de Bibliotecas da USP, 2009.

[4] LEON, Adriana D. Reafirmando o lúdico como estratégia de superação das dificuldades de aprendizagem. In: In: Revista Organización de Estados Iberoamericanos para la Educación, la Ciência y la Cultura (OEI), Anais... SL, vol. 50, no 56/3, p. 1-15, Out., 2011.

[5] PASSOS, Marcos P. de. O ato lúdico de conhecer: a pesquisa como processo dialógico de apropriação de dispositivos informacionais e culturais. 2013. 125 f. Dissertação ( Mestrado em Ciência da Informação) - Escola de Comunicações e Artes, Universidade de São Paulo, São Paulo.

[6] PEREIRA, Jane E. A importância do lúdico na formação de educadores: uma pesquisa na ação do Museu da Educação e do Brinquedo - MEB. 2005. 248 f. Tese (Doutorado em Educação) - Universidade de São Paulo, São Paulo.

[7] SANTOS, Deyvison R.; BOCCARDO, Lilian.; RAZERA, Júlio C. C. Uma experiência lúdica no ensino de ciências sobre os insetos. In: Revista Organización de Estados Iberoamericanos para la Educación, la Ciência y la Cultura (OEI), Anais... SL, vol. 50, no 50/7, p. 1-3, Nov., 2009.

[8] SANTOS, Elza C. Dimensão lúdica e arquitetura: o exemplo de uma escola de educação infantil na cidade de Uberlândia. 2011. 363 f. Tese (Doutorado em Ciências da Informação) - Faculdade de Arquitetura e Urbanismo, Universidade de São Paulo, São Paulo.

[9] SILVA, Alcina M. T. B. da. O lúdico na relação ensino aprendizagem das ciências: resignificando a motivação. In: REUNIÃo ANUAL DA ANPED, 27., 2004 - Caxambu/MG. Anais... Caxambu, MG: Psicologia da Educação, 2004. p. 1-6.

[10] SILVA, Alcina M. T. B. da.; METTRAU, Marsyl B. Proposta de Ensino de Ciências sob forma lúdica e criativa nas escolas. In: SIMPÓSIO NACIONAL DE ENSINO DE FÍSICA - SNEF, 18., 2009 - Vitória, Es. Anais... Vitória, Es. 2009. p. 110.

[11] XIMENES, Sérgio. Dicionário da Língua Portuguesa. 3. ed. Ver. E ampl. Sérgio Ximenes. São Paulo: Ediouro, 2001. 


\section{Capítulo 11}

Formação de professores: Reflexões sobre o Plano Nacional de Formação de Professores da Educação Básica

\section{Cristiane Duque de Souza Pantoja \\ Mateus de Souza Coelho Filho}

Resumo: As transformações históricas, culturais, economicas e sociais, exigem hoje um profissional que corresponda aos novos paradigmas educacionais. Nesse sentido, a formação é um aspecto necessário à ascensão social, pessoal e profissional do professor, considerando que a este são facultadas as tarefas de ensinar, educar e mediar o processo de ensino aprendizagem, bem como preparar o indivíduo para a vida em sociedade. Este estudo teve como objetivo compreender como acontece o processo formativo de professores no PARFOR no CESP, turma de Pedagogia $8^{\circ}$ período. Descobrir quais desafios e dificuldades são enfrentadas pelos professores durante seu processo formativo. Analisar de que maneira 0 PARFOR tem contribuído na prática dos professores. Verificar enquanto política pública os pontos positivos e negativos do PARFOR no processo formativo destes professores. A pesquisa é de natureza qualitativa, com abordagem fenomenológica. Para a coleta dos dados utilizou-se o questionário com perguntas abertas. Verificou-se que os professores de Pedagogia tiveram muitas conquistas com a implantação do PARFOR, porém é preciso implementar condições objetivas para que estes possam usufruir de conquistas muito mais concretas que os fortaleçam em seu processo formativo e profissional.

Palavras-chave: Educação. Reflexões. Formação. Professores. PARFOR. 


\section{INTRODUÇÃO}

As transformações históricas, culturais, economicas e sociais, exigem hoje um profissional que corresponda aos novos paradigmas educacionais. Nesse sentido, a formação é um aspecto necessário à ascensão social, pessoal e profissional do professor, considerando que a este profissional são facultadas as tarefas de ensinar, educar e mediar o processo de ensino aprendizagem, bem como preparar o indivíduo para a vida em sociedade.

Hoje, a formação de professores é um dos pilares dos discursos e políticas públicas que orientadas a difundirem processos formativos, criaram uma infinidade de programas e cursos de fomentação a formação de professores. Nesse contexto encontra-se o PARFOR ${ }^{4}$, instituído nos termos do Decreto 6.755, de 29 de janeiro de 2009, tem o objetivo atender à demanda por formação inicial e continuada dos professores das redes públicas da Educação Básica.

Este estudo teve como objetivo compreender como acontece o processo formativo de professores no PARFOR no CESP, turma de Pedagogia $8^{\circ}$ período. Descobrir quais desafios e dificuldades são enfrentadas pelos professores durante seu processo formativo. Analisar de que maneira O PARFOR tem contribuído na prática dos professores. Verificar enquanto política pública os pontos positivos e negativos do PARFOR no processo formativo destes professores.

Para que os objetivos fossem alcançados utilizou-se a pesquisa qualitativa com o intuito de compreender as percepções dos professores sobre o percurso de formação. Como método de abordagem foi utilizado o fenomenológico, o qual preocupa-se com a descrição da experiência tal como ela é, onde o sujeito/ator é reconhecidamente importante no processo de construção do conhecimento (GIL, 2008; TRIVINOS, 2008). Norteado pelo questionário como tecnica de coleta de dados com perguntas abertas foram levantados os questionamentos pertinentes à pesquisa, onde posteriormente foram analisados a partir da análise de conteúdo, a qual que permitiu interpretar e compreender o fenomeno verificado.

No arcabouço teórico, buscou-se fundamentos nas obras de Gatti (2009), Freitas (1999), Imbernón (2011), Lima (2010), Demo (2000), Nóvoa (1992) dentre outros que abordam e discutem sobre a temática.

A estrutura textual está organizada em três momentos: o primeiro faz referência aos fundamentos teóricos que discorrem sobre a formação e sua possibilidade de ressignificar a prática pedagógica, seus desafios e sobre o PARFOR. O segundo evidencia a trajetória metodológica para alcançarmos os objetivos: o campo da pesquisa, os sujeitos, métodos e técnicas. 0 terceiro trás informações pertinentes a análise e discussão dos dados coletados junto aos professores do PARFOR, turma de Pedagogia.

Diante o exposto, acredita-se que os resultados desta investigação podem contribuir para a compreensão mais profunda de como acontece o processo formativo pelo PARFOR no CESP, revelando muitos aspectos importantes que configuram esse momento de formação, espera-se que tragam reflexões sobre a importância da formação de professores e que proporcionem mecanismos de acesso e permanência em sua formação.

\section{A FORMAÇÃO COMO POSSIBILIDADE PARA RESSIGNIFICAR A PRÁTICA PEDAGÓGICA}

A sociedade contemporânea marcada pelo pragmatismo tecnológico, economico e cultural exige gradativamente a aquisição de habilidades e competências, e como a escola além de espaço de inserção e integração é também espaço de preparação do indivíduo, as políticas públicas tem enfaticamente tentado repaginar a prática pedagógica, buscando desenvolver no professor um perfil cada vez mais articulado com as exigências contemporâneas, especialmente no domínio de saberes, capacidades e habilidades especializadas, que o farão competente no exercício da docência (SOUSA, 2008). A nova era requer um profissional da educação diferente, que esteja preparado para atender a grande diversidade sociocultural que se instaura na instituição escolar (IMBERNóN, 2011).

Nesse sentido, para uma atuação repleta de significação, a formação docente representa um dos elementos fundamentais da educação, "uma das pedras imprescindíveis em qualquer tentativa de renovação do sistema educativo" (GARCIA, 1995, p. 23), ao passo que qualquer mudança no contexto da educacional, 
deve começar pelo processo de formação dos professores, mudanças que se estenderão a sociedade como um todo por meio da prática pedagógica dos professores.

Imbernón (2010) enfatiza que a formação é o fomento de desenvolvimento pessoal, profissional e institucional dos professores, elevando seu trabalho para transformação de uma prática pedagógica desenvolvida ao longo da profissão, constantemente sujeita a experimentação do novo. Face a essa atualização, a formação de professores é uma área de conhecimentos, investigação, propostas teóricas e práticas, que no âmbito da didática e da organização escolar permite o desenvolvimento do ensino, do currículo e da escola, com o objetivo de melhorar a educação dos alunos que a recebem (GARCIA, 1999).

Para tanto, compreende-se a formação como busca da qualificação baseada na possibilidade de redimensionar o desenvolvimento do ensino e da educação, onde os professores versam suas experiências integrando-as a novas maneiras de desenvolver a prática pedagógica.

As perspectivas por uma prática pedagógica dinâmica e diferenciada são perceptíveis, hoje não se ensina mais como antes, os alunos esperam aulas mais interessantes, que os oriente a reflexão e a ação, por isso a formação assume um papel que transcende o ensino que pretende uma mera atualização científica, pedagógica e didática e se transforma na possibilidade de criar espaços de participação, reflexão e formação para que as pessoas aprendam e se adaptem para poder conviver com mudança e a incerteza (IMBERNÓN, 2011).

Indubitavelmente, a formação é fator indispensável para que o professor acompanhe as mudanças que ocorrem na sociedade atual, bem como para prepará-lo a estar apto e contribuir na formação de pessoas, visto que não apenas ensina, mas educa. Assim sendo, uma nova prática pedagógica só será possível se o professor souber contextualizar novas situações, criando novas maneiras de articulação dos saberes na construção da docência, dialogando com os envolvidos no processo da formação (IMBERNÓN, 2010).

Todo esse movimento exige reflexão e compreensão, é inegável que para um fazer pedagógico crítico e autonomo, a formação seja contínua, considerando que na formação permanente dos professores, o momento fundamental é o da reflexão crítica sobre a prática. É pensando criticamente a prática de hoje ou de ontem que se pode melhorar a próxima prática. 0 próprio discurso teórico, necessário à reflexão crítica tem de ser de tal modo concreto que quase se confunda com a prática (FREIRE, 2011).

0 desafio então seria formar professores que busquem compreensões diversificadas sobre sua realidade, com o objetivo de transformá-la. A inovação, a criticidade, a criatividade e o diálogo seriam aspectos peculiares a essa nova compreensão, onde o professor analisa, interpreta e reflete sobre sua realidade com o intuito de intervir e mudar sempre que necessário.

Serrano (1990) afirma que é fundamental que esse professor seja capaz de analisar o contexto de sua atividade e de planejá-la, de dar resposta a uma sociedade em mudança. Partindo do pressuposto mencionado pela autora enfatiza-se novamente que o processo formativo seja consistente, que ofereça possibilidades ao professor para adequar-se as mudanças que ocorrem no bojo da sociedade, tendo em vista que a concepção moderna de educador exige "uma sólida formação científica, técnica e política, viabilizadora de uma prática pedagógica crítica e consciente da necessidade de mudanças na sociedade brasileira" (BRZEZINSKI; GARRIDO, 2001, p. 83).

Por fim, se o desafio atual da educação brasileira é garantir uma prática pedagógica inovadora, contextualizada, crítica, reflexiva e eficiente, pressupomos que a formação continuada seja uma vertente indispensável para alcançar tal desafio, embora reconheçamos também que outros fatores sejam importantes para essa abordagem.

\section{DESAFIOS NA FORMAÇÃO CONTINUADA NO BRASIL}

As inúmeras políticas públicas desenvolvidas nas últimas décadas têm apostado em programas de fomentação à formação de professores, o que tem sido um grande desafio em todo o país. No Brasil, segundo Gatti (2000) cresceu geometricamente o número de iniciativas colocadas sob o grande guardachuva "educação continuada", há um movimento intenso rumo as novas práticas pedagógicas sociais.

Por um lado esse mesmo movimento tem oferecido a oportunidade de aperfeiçoamento profissional para os professores, por outro lado tem sido contraditório, configurando-se como um precário processo de certificação e/ou diplomação e não qualificação e formação docente para o aprimoramento das condições do exercício profissional (FREITAS, 1999). 
Nesta mesma linha de raciocínio Nóvoa (1992) destaca que é preciso reconhecer as deficiências dos atuais programas de formação, é necessário o desenvolvimento de projetos que produzam mudanças significativas na vida pessoal e profissional do professor.

A implementação e a organização das políticas públicas educacionais que fundamentam esses programas nesse contexto, são aspectos a serem considerados, analisando a relevância do processo formativo. Nunes (1978) argumenta que essa inconsistência no processo formativo de professores pode está associada à importação e reprodução de conhecimentos de outros países, que contrapõe a realidade brasileira. Hamburger (1980) analisando a formação continuada afirma que a regulamentação da pós- graduação no Brasil foi copiada até nos mínimos detalhes da norte-americana.

Vale ressalvar que "copiar" não é totalmente o problema, mas um desafio, se consideradas as diferenças existentes entre os países norte-americanos em relação ao Brasil, "é difícil precisar em que medida a organização e os procedimentos administrativos norte-americanos podem ser adotados integralmente em nosso meio, dadas as diferenças existentes entre a nossa estrutura universitária e a daquele país" (GÓES, 1997, p. 26).

Outro aspecto implicante no processo formativo é o fator financeiro, com um baixo salário, o professor quase não tem perspectivas de continuar os estudos e expandir a carreira profissional. Segundo Siniscalco (2002) o Brasil tem a terceira pior remuneração de professores, se comparada as profissões que exigem habilitações academicas muito menores, como pedreiro, vendedor, carteiro, motorista de ônibus, enfermeiro auxiliar, etc.

Esse desprestígio a profissão docente, pode está repercutindo no alto índice de exoneração e baixa atratividade pela profissão. Estudos da $\mathrm{CNTE}^{5}$ revelaram que na próxima década o Brasil corre o risco de ficar sem professores na educação básica e explicam que o desinteresse dos jovens pela área está associado aos baixos salários, violência nas escolas e superlotação das salas de aula.

Não obstante, em meio a esse contexto esfacelado, desmotivante e até mesmo angustiante, cabe destacar o aspecto salarial como um agravante social. Para Esteve (1999) paralelamente a desvalorização salarial produziu-se uma desvalorização social da profissão docente. Outros agravantes no processo formativo são abordados nos estudos realizados por Gatti (2009), os quais constataram que:

[a] A maioria dos formadores não tem conhecimento dos contextos escolares e dos professores que estão a formar.

[b] Os programas de formação não prevêem acompanhamento e apoio sistemático da prática pedagógica dos docentes.

[c] Os professores têm dificuldades de prosseguir em suas práticas com eventuais inovações no término do programa.

[d] A descontinuidade das políticas e orientações do sistema dificulta a consolidação dos avanços alcançados.

Em linhas gerais estes estudos expressam a pouca consistência dos cursos de formação quanto ao contexto real dos formandos, a falta de referência das suas experiências, a ausência contínua do aperfeiçoamento formativo, e falta de incentivo dos órgãos competentes não só no sentido de monitoramento, mas também de investimento à novas oportunidades.

Se o professor é a pedra de toque da qualidade educativa como afirma Demo (2000), então todos os seus interesses devem ser repensados, logo, a formação com o papel basilar que exerce deve ser ressignificada constantemente.

Em suma, cabe destacar que no processo formativo os desafios estarão sempre presentes, que além destes aqui mencionados existem outros e tudo isso implica na necessidade de uma melhor consistência das políticas públicas, que melhorem as condições de oferecimento, organização e efetividade dos programas ou planos que fomentam a formação continuada destes profissionais. 


\section{PLANO NACIONAL DE FORMAÇÃo DE PROFESSORES DA EDUCAÇÃo BÁSICA: BREVES CONSIDERAÇÕES}

Na Lei de Diretrizes e Bases da Educação Brasileira, no artigo 62, está explícito que a formação de docentes para atuar na educação básica far-se-á em nível superior, em curso de licenciatura, de graduação plena, em universidades e institutos superiores de educação, admitida, como formação mínima para o exercício do magistério na educação infantil e nos 5 (cinco) primeiros anos do Ensino Fundamental, a oferecida em nível médio na modalidade normal (Redação dada pela Lei $n^{\circ} 12.796$, de 2013).

Visando a efetivaçâo das leis e as metas do $\mathrm{PNE}^{6}$ surgiu no Brasil um diversificado panorama de programas, cursos e planos que visam o fortalecimento das políticas de formação de professores, acreditando numa educação de qualidade, pautada na necessidade de renovação constante do trabalho pedagógico e melhoria de desempenho dos estudantes, dentre estes está o PARFOR.

O Plano foi instituído nos termos do Decreto 6.755, de 29 de janeiro de 2009, e tem a finalidade de atender à demanda por formação inicial e continuada dos professores das redes públicas de educação básica, é uma ação conjunta do $\mathrm{MEC}^{7}$, por intermédio da $\mathrm{CAPES}^{8}$, em colaboração com as Secretarias de Educação dos Estados, Distrito Federal e Municípios e as IPES.

O PARFOR objetiva alcançar umas das metas do PNE para os decenios 2011 a 2020, no que diz respeito à qualificação de professores, e até então está meta vem sendo alcançada, considerando que desde a sua implantação, muitos professores tiveram a oportunidade do acesso ao níver superior e também de graduarse em áreas específicas, o que significa um grande avanço na educação brasileira.

As pré-inscrições são feitas mediante o sistema eletrônico denominado "PLATAFORMA FREIRE", gerenciado pelo MEC, através do site: http://freire.mec.gov.br, onde os professores fazem um cadastro, seguido da inscrição que posteriormente será analisada e validada pelas secretarias de educação estaduais e municipais e por fim serão matriculados pelas universidades. Os professores selecionados irão receber a formação durante o recesso das férias, de forma intensiva de segunda a sábado, com carga horária de 8 horas diárias (8:00 às 12:00h e 14:00 às 18:00h), conforme definido no cronograma de oferta de cada curso ou instituição, dependendo do curso, e em cada módulo são estudadas entre 05 a 06 disciplinas.

A CAPES é responsável pelo aspecto financeiro, além de parceira também para o cumprimento do regime de colaboração estabelecido no PARFOR, em que o papel do Estado é gerir o Plano como um todo, das universidades é dispor o seu quadro docente e de infraestrutura, das secretarias e prefeituras, dispor os professores da rede municipal e estadual de ensino da educação básica. Ao INEP ${ }^{9}$ Anísio Teixeira e ao FNDE $^{10}$ cabe fazer o acompanhamento e avaliação do programa de formação de professores.

\section{PERCURSO METODOLÓGICO}

Nesta etapa será descrita a trajetória metodológica para que se pudesse alcançar os objetivos propostos pela pesquisa, trajetória que vai desde a leitura de obras de referentes a temática objeto de investigação, até a escolha dos métodos, coleta, tabulação e organização dos dados, bem como análise dos mesmos.

0 estudo foi norteado pela pesquisa qualitativa, pois buscou-se desvendar questões peculiares ao objeto de estudo. Segundo Minayo (1995) a pesquisa qualitativa responde a questões muito particulares. Ela se preocupa, nas ciências sociais, com um nível de realidade que não pode ser quantificado, ou seja, trabalha com o universo de significados, motivos, aspirações, crenças, valores e atitudes, o que corresponde a um espaço mais profundo das relações dos processos e dos fenomenos que não podem ser reduzidos à

\footnotetext{
${ }^{6}$ Plano Nacional da Educação

${ }^{7}$ Ministério da Educação e Cultura

${ }^{8}$ Coordenação de Aperfeiçoamento de Pessoal de Nível Superior

Instituições Públicas de Educação Superior

${ }^{10}$ Instituto Nacional de Estudos Pedagógicos

${ }^{11}$ Fundo Nacional de Desenvolvimento da Educação
} 
operacionalização de variáveis. Na perspectiva qualitativa, o ambiente natural é a fonte direta para a coleta de dados, e estes são analisados para sequenciadamente serem apresentados.

Nessa perspectiva utilizou-se como método de abordagem, o fenomenológico, o qual preocupa-se com a descrição da experiência tal como ela é, onde o sujeito/ator é reconhecidamente importante no processo de construção do conhecimento (GIL, 2008; TRIVINOS, 2008).

Para a coleta de dados foi utilizado o questionário com perguntas abertas, o qual segundo Trivinos (2008) tem como característica questionamentos básicos que são apoiados em teorias e hipóteses que se relacionam ao tema da pesquisa. Através desta técnica foi possível focalizar o objetivo do estudo e analisar as concepções dos sujeitos. Trivinos, ainda afirma que o questionário favorece não só a descrição dos fenómenos sociais, mas também a explicação e compreensão de sua totalidade, além de manter a presença consciente e atuante do pesquisador no processo de coleta de informações.

A análise dos dados procedeu-se através da análise de conteúdo. Segundo Moraes e Galiazzi (2011) este investe tanto em descrição como em interpretação. A descrição nesta perspectiva de análise é uma etapa muito importante e necessária. As categorias construídas no processo de análise de algum modo envolvem tanto descrição como interpretação, de forma que a conjugação da primeira e da segunda faça emergir dos sujeitos concepções a respeito do sujeito investigado.

A trajetória metodológica deste estudo iniciou-se a partir do diálogo com à Coordenação do PARFOR do CESP, a fim de descobrirmos o início do programa neste local, os cursos oferecidos, carga horária, alunos matriculados, dentre outros aspectos. Posteriormente apresentamos o projeto de pesquisa aos académicos de Pedagogia do $8^{\circ}$ período, justificando a importância da pesquisa, as questões norteadoras, objetivos, etc., e por fim solicitamos a participação destes para o sucesso da pesquisa.

No final agendamos a aplicação dos questionários junto aos academicos, os quais foram respondidos no início do mês de julho de 2014, por fim realizou-se a análise e interpretação dos dados coleíados, os quais nos possibilitaram a concretização dos objetivos da pesquisa.

O momento de análise dos dados seguiu pressupostos teóricos, Moraes e Galiazzi (2011) ressaltam a descrição como a apresentação de distintos elementos, representados pelas diferentes categorias construídas, produzindo proposições ou enunciados que enumerem qualidades, propriedades, características do objeto ou fenomeno investigado, ou seja, criam possibilidade de uma nova e profunda compreensão.

Os dados coletados nos possibilitaram compreender como acontece o processo formativo dos professores que estudam no PARFOR, descobrir quais dificuldades são enfrentadas por estes durante esse processo, analisar de que forma o PARFOR tem contribuído na prática pedagógica e verificar quais os pontos positivos e negativos do PARFOR no processo de formação, enquanto política pública. Os resultados permitiram compreender esse processo formativo docente, que abriga em suas amplitudes tantas singularidades importantes ao desfecho da educação, ao mesmo tempo em que nos faz refletir sobre novas possibilidades de fomentação da formação continuada.

\section{CONTEXTO E SUJEITOS DA PESQUISA}

O contexto da pesquisa foi o CESP, localizado à Rua Odovaldo Novo, Djard Vieira s/n. O CESP-UEA possui uma estrutura física que é composta de (01) Biblioteca informatizada, com 3.867 títulos e 12.283 exemplares no seu acervo, (14) salas de aula climatizadas com data show, televisão e computador para auxiliar na projeçâo das aulas, (01) laboratório de informática com (40) computadores com acesso livre à internet e intranet, laboratórios de Física (01), Ciências Biológicas (01) e Química (01), todos informatizados, (01) sala de professores e 01 auditório com palco com capacidade para 400 (quatrocentas) pessoas, centro de convivência onde se realizam os eventos e projetos de extensão da Universidade.

Pela descrição, verifica-se que o CESP, possui uma infraestrutura boa e capaz de oferecer aos alunos qualidade na execução de suas atividades. Constituíram-se como sujeitos da pesquisa os academicos do PARFOR do ano de 2010 da turma de Pedagogia do $8^{\circ}$ período, da Universidade do Estado do Amazonas. Estão matriculados nessa turma 36 alunos, sendo que desta pesquisa participaram apenas 28, ou seja, $78 \%$ do universo total. 


\section{O PLANO NACIONAL DE FORMAÇÃO DE PROFESSORES DA EDUCAÇÃO BÁSICA NO CENTRO DE ESTUDOS SUPERIORES DE PARINTINS}

Em Parintins-AM, o PARFOR teve início em 2009 com 02 turmas de $1^{\text {a }}$ Licenciatura, Pedagogia e Matemática. Atualmente funcionam 05 turmas: 02 de Pedagogia, 01 de matemática, 01 de História e 01 de Letras, sendo que Pedagogia e Letras são cursos oferecidos da $1^{\text {a }}$ Licenciatura e História e Matemática da $2^{\mathrm{a}}$ Licenciatura. A tabela 01 apresenta o quantitativo de alunos matriculados nos referidos cursos do CESP.

Tabela 01: Quantitativo de acadêmicos do PARFOR matriculados no CESP.

\begin{tabular}{|c|c|c|}
\hline \multicolumn{2}{|l|}{ Cursos } & Alunos Matriculados \\
\hline Pedagogia & (1르 Licenciatura) & 36 \\
\hline Pedagogia & (1흐 Licenciatura) & 39 \\
\hline Letras & (1모 Licenciatura) & 32 \\
\hline Matemática & (2 ${ }^{\mathrm{a}}$ Licenciatura) & 26 \\
\hline História & (2 ${ }^{\mathrm{a}}$ Licenciatura) & 29 \\
\hline Total & & 162 \\
\hline
\end{tabular}

Fonte: Coordenação do PARFOR CESP.

Conforme a tabela, os cursos com maior quantidade de alunos (professores) são os de 1a licenciatura, o que implica destacar que ainda existe um número considerável de professores sem nível superior, em busca da formação inicial. São representados com o percentual de $66 \%$ de alunos do total geral, mais da metade dos cursistas.

Nos cursos de $1^{\text {a }}$ licenciatura a carga horária é de 2.800 horas, sendo que 400 horas são para o estágio supervisionado que corresponde a mesma carga horária dos cursos regulares e os de $2^{\mathrm{a}} 1.200$ horas, incluindo as horas do estágio. Ressalta-se que na $2^{\text {a }}$ licenciatura os alunos já possuem alguma graduação e irão apenas fazer a complementação de disciplinas. Segundo a Coordenação do PARFOR do CESP, 95\% dos cursistas da $2^{\text {a }}$ licenciatura são graduados em Normal Superior, o que congratula o PARFOR, visto que estes profissionais estão adquirindo conhecimentos para atuarem em disciplinas específicas.

Quanto aos formadores, estes são oriundos do próprio CESP, exceto alguns casos específicos que são contratados para suprir a necessidade da grade curricular dos cursos.

Quando buscou-se conhecer os sujeitos desta pesquisa, inicialmente foram verificadas algumas variáveis como idade, tempo de serviço, contexto de atuação, localização e motivos da continuidade dos estudos, as quais nos ajudaram complementar e aprofundar a análise, na tabela estão expressas estas variáveis.

Tabela 01: Variáveis dos acadêmicos do PARFOR matriculados no CESP.

\begin{tabular}{|c|c|c|}
\hline Idade & Tempo de Serviço & Contexto de Atuação \\
\hline $\begin{array}{l}50 \% \text { estão na faixa etária de } \\
30 \text { à } 35 \text { anos, } \\
18 \% \text { entre } 46 \text { à } 50 \text { anos, } \\
14 \% \text { entre } 36 \text { à } 40 \text { anos, } \\
11 \% \text { entre } 41 \text { à } 45 \text { anos, } \\
7 \% \text { de } 51 \text { à } 55 \text { anos. }\end{array}$ & $\begin{array}{l}71 \% \text { atuam entre } 06 \text { à } 10 \text { anos, } \\
14 \% \text { atuam de } 11 \text { à } 15 \text { anos, } \\
7 \% \text { atuam de } 16 \text { à } 20 \text { anos, } \\
7 \% \text { atuam de } 26 \text { à } 30 \text { anos. }\end{array}$ & $\begin{array}{l}57 \% \text { ministram aulas na zona } \\
\text { rural. } \\
43 \% \text { ministram aulas na zona } \\
\text { urbana. }\end{array}$ \\
\hline
\end{tabular}


Sobre essas variáveis, percebe-se que os sujeitos da pesquisa apresentam idades distintas, possuem experiências na área de educação há algum tempo, são professores de diferentes localizações geográficas, até mesmo de outros estados e em sua maioria ministram aulas na zona rural dos Municípios de Parintins, Barreirinha, Faro e Juruti.

Destaca-se ainda, na variável contexto de atuação que dos 57\% que atuam na zona rural, $63 \%$ são de Parintins-AM, 31\% de Barreirinha-AM, 6\% de Juruti-PA, e dos 43\% da zona urbana 75\% atuam em Parintins, 17\% atuam em Faro-PA, 8\% atuam em Barreirinha-AM.

Quando se questionou sobre os motivos de retomar os estudos, os professores enfatizaram a necessidade de aperfeiçoamento, de melhoria de sua práxis, mas principalmente pelas exigências do mercado de trabalho competitivo que vivenciamos. "O retorno aos estudos é necessário, [...] a competitividade do mercado de trabalho, tem exigido cada vez mais qualificação profissional, quem não se atualiza perde seu espaço" (Acadêmico A). De acordo com Gatti (2008) as cobranças do mundo do trabalho tornaram-se forte imperiosidade da formação.

Entretanto, é imprescindível almejar a formação também como requisito para a dinamização e melhoria do processo de ensino-aprendizagem, destacada pelo (Acadêmico B) “[...], retomar os estudos nos garante a possibilidade de compreensão dos campos científicos e teóricos que fundamentam a prática docente e o processo de ensino-aprendizagem".

Desses relatos observa-se que existe a necessidade da inserção no mercado de trabalho, da atualização do trabalho docente para uma desenvoltura pedagógica mais fundamentada, e que o ensino superior é um suporte que pode garantir esses anseios. Em síntese, os motivos de retomar os estudos revelam as possibilidades que os professores veem no processo formativo contínuo e destacam a importância para o seu crescimento profissional e pessoal.

\section{O PROCESSO FORMATIVO NO PLANO NACIONAL DE FORMAÇÃO DE PROFESSORES DA EDUCAÇÃO BÁSICA}

A formação é um caminho para a qualificação profissional, satisfação pessoal que oportuniza mudanças na vida do professor, submetendo-o a refletir sobre seu próprio trabalho. No PARFOR, essa construção da consciência crítica tem resultado em experiências significativas, demonstrando que o processo formativo dos acadêmicos de Pedagogia do $8^{\circ}$ período do CESP tem produzido mudanças importantes, conforme podemos observar no relato do (Acadêmico C) "hoje, posso afirmar que o processo formativo do Parfor, está transformando minha vida pessoal e profissional. Minha prática pedagógica mudou [...], tenho uma visão de mundo diferente, reconheço que não sou mais a mesma, somente aquela que ensina, mas que aprende junto com os alunos".

Essa nova percepção do academico, desenvolvida ao longo dos quatro anos de formação, nos remonta ao pensamento de Freire (2011, p.23-51) quando assevera que "[...] não há docência sem discência, as duas se explicam e seus sujeitos, apesar das diferenças que as conotam [...], quem ensina aprende ao ensinar e quem aprende ensina ao aprender".

O expressado pelo academico $\mathrm{C}$ deixa claro que antes da formação, os conhecimentos dos alunos eram negligenciados, mas no decorrer do curso ele passa a percebê-los como componentes do processo de ensino e a reconhecer-se como sujeito que aprende junto aos estudantes.

Além disso, as análises dos questionários permitiram observar que o processo formativo no PARFOR tem sido gratificante, pois tem oportunizado a ressignificação de práticas pedagógicas, novas concepções e percepções, bem como expressou o (Acadêmico D) "esse processo é gratificante, assegura-me como profissional crítico, de compromisso e responsabilidade com a formação do indivíduo para a sociedade, [...], a cada período estamos ganhando e adquirindo conhecimentos através de experiências compartilhadas e sendo sempre impulsionados e motivados para novas ações metodológicas em nossas práticas".

As contribuições dos acadêmicos nos levam a compreender que o processo formativo do PARFOR tem se configurado num cenário pautado pelo conhecimento, troca de experiências, enriquecimento metodológico, emancipação pessoal e profissional. Como plano de formação de professores, esse processo tem fortalecido não somente os anseios preconizados pelas políticas públicas no que tange a formação, mas os mais particulares, por está permitindo a formação de profissionais, autônomos, refletivos e dinâmicos. Nesse sentido o (Acadêmico E) argumenta que "O PARFOR foi um dos melhores programas de formação que já surgiu, estamos tendo a oportunidade de aprender, logo, oferecer aos nossos alunos um ensino mais dinâmico. Sou muito grata por essa oportunidade que só tem enriquecido minha formação". 
Contextualizando as expressões acima, verifica-se que o processo formativo no PARFOR está contribuindo para a equidade das situações que envolvem o ensino e indicam que o professor quando é instigado e impulsionado a vivenciar novas situações de tal modo que isso reflete-se numa postura diferente no desenvlvimento de sua prática pedagógica dentro da sala de aula.

\section{DIFICULDADES NO PROCESSO FORMATIVO DO PLANO NACIONAL DE FORMAÇÃO DE PROFESSORES DA EDUCAÇÃO BÁSICA}

No tópico anterior discorremos sobre como está sendo o processo formativo no PARFOR e os relatos evidenciam a importância do curso para os acadêmicos de Pedagogia. Todavia é relevante destacar quais as dificuldades enfrentadas por estes, durante seu processo formativo. A LDB no artigo 62, parágrafo 4§ assevera que "A União, o Distrito Federal, os Estados e os Municípios adotarão mecanismos facilitadores de acesso e permanência em cursos de formação de docentes em nível superior para atuar na educação básica pública" (Incluído pela Lei no 12.796, de 2013).

Inegavelmente, o PARFOR corresponde às políticas públicas quanto a promoção da formação inicial e continuada dos professores, e mostra explicitamente que a legislação tem sido efetiva nesse aspecto. Mas, quanto a esses mecanismos facilitadores para garantir o acesso e a permanência dos docentes nos cursos de formação, ainda restam muitas lacunas.

As dificuldades dos professores correlacionam-se especificamente a falta de incentivo, compreensão e apoio das secretárias de educação como bem afirma o (Acadêmico F) "As dificuldades voltam-se para a forma opressiva e não compreensiva da SEMED e da comunidade onde atuo como professor, porque os comunitários não aceitam que me ausente da sala de aula, solicitam um professor substituto, mas a SEMED não contrata".

Associado ao relato do academico anterior, o (Acadêmico G) diz que a burocracia para se ausentar da sala de aula também é fator agravante nesse processo "[...] tenho que entregar vários documentos e dá muitas satisfações para chegar ao PARFOR [...], a falta de compreensão do gestor da escola, e a minha retirada da folha de pagamento por ser S.P são algumas das muitas dificuldades".

Esses relatos mostram as dificuldades quanto ao apoio das entidades competentes em facilitar a formação docente. Os acadêmicos sentem-se desmotivados e desprovidos de recursos necessários para suprir as necessidades básicas, a falta de incentivo, apoio e investimento podem comprometer o processo de formação.

É oportuno destacar que essa falta de investimento tem resultado em outros aspectos bastante implicantes nesse processo, o econômico. A esse respeito o (Acadêmico H) afirma que "uma das grandes dificuldades é que sou S.P e todo ano no período não letivo ficamos sem receber e pra mim é muito difícil, pois não tenho casa em Parintins, e também como manter os meus estudos".

A mesma situação é revelada pelo (Acadêmico I) "durante os meses de janeiro e fevereiro saio da folha de pagamento, devido ser serviço prestado, a prefeitura não considera essa questão [...], também não disponibiliza substituições para o professor em formação".

O (Acadêmico J) justifica complementando que "a maior dificuldade é a situação econômica, é a que tem maior influência, por exemplo, pago aluguel, transporte, apostila, tenho que dividir o dinheiro com a família [...], por outro lado não é fácil ficar longe da família, principalmente dos filhos". A questão da retirada dos professores da folha de pagamento tem prejudicado o processo formativo segundo os mesmos. Nesse sentido, não estão sendo criados mecanismos facilitadores a fim de garantir o processo de formação.

Em entrevista a Revista Escola, Antonio Novóa, educador e escritor foi questionado quanto a maneira que o governo e a escola podem agir para fortalecer o processo formativo docente. Em resposta a entrevista o autor argumentou que "eles devem criar condições básicas, como infraestrutura e incentivos à carreira. Só o profissional, não pode se responsabilizar por si só por sua formação".11

Por outro lado, destacam-se ainda outras dificuldades, como por exemplo, a afetiva e o cansaço. Pelo fato do PARFOR ser oferecido durante as férias, os professores que já atuam durante o ano letivo, têm pouco tempo para a família, além disso, precisam de disposição para estudar, essas duas questões também foram enfatizadas pelo (Acadêmico L) docentes. "Ficar longe da família é muito difícil, morar na casa dos outros é

${ }^{11}$ Publicado em NOVA ESCOLA Edição 256, Outubro 2012. Título original: “A Educação assumiu muitas tarefas”. É o fenômeno da escola transbordante. 
um desafio, além de todo o cansaço que trazemos da escola, porque não temos férias, é bem complicado estudar, às vezes nos falta disposição, o cansaço é grande, tem momentos que dá vontade de desistir, não sabemos mais o que é descontrair, estudamos de segunda a sábado, e nos domingos restam os trabalhos, a família tem ficado em segundo plano".

Portanto, diante desses relatos, observa-se que são muitas as dificuldades enfrentadas durante o processo formativo no PARFOR, mas a situação financeira é um agravante mais pertinente, que, aliás, tem sido responsável pela desistência constante de universitários.

\section{CONTRIBUIÇÕES DO PLANO NACIONAL DE FORMAÇÃO DE PROFESSORES DA EDUCAÇÃO BÁSICA NA PRÁTICA PEDAGÓGICA}

A sociedade do conhecimento e da informação requer, de modo geral, profissionais capacitados que respondam as exigências, transformações, às novas demandas sociais e até mesmo o próprio mercado de trabalho. Destes profissionais, espera-se também que estejam de acordo com a Lei de Diretrizes e Bases (LDB 9394/96) em permanente formação para o seu aprimoramento profissional. Nesse sentido, o PARFOR surge como oportunidade de aperfeiçoamento profissional, de oportunidades rumo a novas formas de organização e articulação do trabalho pedagógico, bem como inserção social.

Essa perspectiva é correspondida pelos sujeitos dessa investigação que demonstraram que o PARFOR tem contribuído positivamente na prática pedagógica, oportunizando uma nova concepção, postura e direção frente a sua atuação.

A respeito dessa contribuição do PARFOR na prática pedagógica, o (Acadêmico M) relatou que "o processo de formação no Parfor tem contribuído na construção da minha consciência crítica e reflexiva da prática pedagógica quanto ao uso e compreensão dos métodos de ensino e a tendência didático-pedagógica". Conforme Gimeno Sacristán (1999), o professor assume a função de guia reflexivo, ou seja, é aquele que ilumina as ações de sala de aula e interfere significativamente na construção do conhecimento do aluno.

A experiência do academico e a concepção de Sacristán (1999) revelam a importância da reflexão no desenvolvimento da prática pedagógica, e ao realizar essa tarefa, o professor sujeita-se as mudanças que subsidiarão o processo de ensino-aprendizagem.

Oportunizar transformações na prática pedagógica, viabilizando mecanismos para a sua execução e produzir mudanças, são, portanto, expectativas que o PARFOR felizmente tem galgado. $\mathrm{O}$ (Acadêmico $\mathrm{N}$ ) afirma que "O PARFOR tem contribuído grandemente em minha prática pedagógica, de maneira que pude mudar minhas metodologias e conquistar o interesse de meus alunos".

Neste relato, confirma-se novamente a relevância do PARFOR no desenvolvimento da prática docente. A expressão "mudar minhas metodologias" citada pelo academico, concluída com "o interesse dos alunos" pressupõe que anteriormente a formação do PARFOR, a metodologia utilizada era desinteressante aos alunos.

Masetto (1997) insinua que a sala de aula é um espaço de vivência, onde o aluno encontra subsídios para vivenciar experiências cotidianas que os conduziram a ação e reflexão.

Outro ponto mencionado pelos academicos diz respeito a relação teoria e prática, que ainda hoje perpetua-se como um desafio para muitos professores, mas que pode ser superado a partir da formação continua e das experiências em sala de aula. Tal fato fica expresso no relato do (Acadêmico 0) ao afirmar que "O PARFOR me possibilitou relacionar a teoria com a prática, saber empregar os conteúdos de maneira clara e objetiva, permitindo as intervenções dos alunos. [...], tinha dificuldades em fazer uso dos conteúdos, não sabia como trabalhar, minha prática era apenas de transmissão".

Esse enfoque evidencia a superação do docente em relacionar teoria e prática e a segurança deste, notavelmente observa-se uma postura tradicional que antecede a formação inicial, onde o aluno é o receptor de informações e o professor transmissor, que foi modificada durante o processo formativo vivenciado atualmente pelo academico no PARFOR. Romper com a barreira dicotômica que envolve o processo teoria e prática é necessário, até porque nenhuma prevalece sobre a outra, ambas são interdependentes, a teoria (projeto de uma prática inexistente) determina a prática real e efetiva (COELHO, 1996).

Em análise última, observamos que o PARFOR tem contribuído na mudança da prática pedagógica dos professores, em seu processo reflexivo, autônomo, que permite criar e recriar metodologias diferenciadas que resultem numa atuação significativa e coerente aos interesses dos alunos. 


\section{O PLANO NACIONAL DE FORMAÇÃo DE PROFESSORES DA EDUCAÇÃo BÁSICA: PONTOS POSITIVOS E NEGATIVOS}

O PARFOR tem galgado um espaço ímpar enquanto política focal que promove a formação de professores, no entanto como um plano existe alguns pontos positivos e negativos. Dos pontos positivos verificou-se que através deste o professor desenvolve o senso crítico, conhece as estruturas do sistema educacional, a legislação, bem como a renovação de sua prática, como esclarece o (Acadêmico P) em seu relato que "[...] $O$ PARFOR tem possibilitado a reflexão sobre o funcionamento do sistema de ensino, a organização da prática pedagógica e do planejamento, as especificidades que compõem o processo de ensino-aprendizagem, além de viabilizar nossa qualificação profissional".

Ainda pelo PARFOR os professores têm inserindo-se nos padrões normativos previstos na legislação. 0 (Acadêmico Q) "É um progresso, veio beneficiar os professores que não tinham graduação. É uma oportunidade de aperfeiçoamento e qualificação profissional".

Esses pontos, deixam claro a satisfação pessoal e profissional dos docentes quanto a fomentação da formação continuada, os relatos dos sujeitos da pesquisa apregoam a importância da formação, o que foi confirmado também nos tópicos anteriores.

Todavia, por se tratar de uma proposta nova, muitos aspectos no PARFOR ainda precisam ser melhorados. Dentre os pontos negativos verificou-se a questão do aceleramento da formação. "[...] é corrido, esse seria o ponto negativo, porque as disciplinas estudadas passam rapidamente, o professor faz o resumo do resumo, tem disciplinas que tem 60 horas e estudamos em 8 dias, os alunos que estudam regularmente, estudam em 3 meses" (Acadêmico R).

Scheibe (2006), a esse respeito afirma que essa defasagem histórica existente no país na formação dos seus docentes, tem propiciado cursos de qualidade duvidosa, demandados pelo poder público.

Nessa mesma linha de raciocínio o (Acadêmico S) ressaltou "por ser uma graduação que ocorre no período das férias, [...], o tempo é muito curto e também se torna bastante cansativo". Esse contexto acaba por atribuir um efeito contrário do que se espera de um curso de formação, adquire um significado de avanços legais e recuos pragmáticos, ou seja, por um lado há um avanço no aspecto legal que oportuniza a formação contínua, mas por outro o sincronismo de ideias que descaracterizam a formação em sua dimensão intelectual crítica, que possibilita ao profissional da educação compreender a realidade do seu tempo (FREITAS, 2002).

Ainda como ponto negativo foi destacado a falta de materiais gráficos, como apostilas, como destaca o (Acadêmico T) "na minha opinião é preciso haver mais interesse da coordenação do curso, para com o nosso material, as apostilas chegam com muito atraso, e na maioria das vezes não chegam".

É importante trazer, ao final desta exposição, de maneira sintética, duas posições sobre o PARFOR que o configuraram no decorrer dos relatos dos sujeitos desta pesquisa, a primeira que vê o PARFOR como política pública que assiste o professorado em processo de formação e que garante a legitimidade da legislação, e a segunda, que é necessário reconhecer e avaliar alguns aspectos desse plano, a fim de fortalecer o processo formativo dos professores.

\section{CONSIDERAÇÕES FINAIS}

Discorremos no desenvolvimento deste trabalho que a formação é um aspecto ímpar no fortalecimento pessoal e profissional da profissão docente, e também um recurso para se adequar aos novos paradigmas educacionais e a inserção social. Por tudo isso essa investigação que buscou analisar como acontece o processo formativo dos professores do PARFOR turma de Pedagogia do CESP, nos possibilitou ampliar, descobrir, vivenciar e compartilhar experiências, que nos enriqueceram também pessoalmente e profissionalmente.

Analisou-se que o processo formativo dos professores de Pedagogia do $8^{\circ}$ período do CESP está ocorrendo de maneira gratificante, o PARFOR tem fomentado significativamente o processo formativo dos professores, contribuindo para sua formação integral, fundamentando a prática pedagógica e oportunizando a inserção dos professores nos parâmetros legais, além de facultá-los a conquista da autonomia pessoal e profissional.

Descobriu-se ainda que persistem durante o processo formativo muitas dificuldades que tem influenciado e que necessitam ser reavaliadas, uma vez que a legislação garanti a formação, cabe aos órgãos, secretárias 
estaduais e municipais efetivar esses direitos e investir nesse processo tão importante ao professor, mas também ao aluno.

Verificou-se também que o processo formativo tem contribuído para o surgimento de uma prática pedagógica mais dinâmica, marcada pelo feedback de ideias de professor x aluno, permitindo a reflexão sobre o trabalho pedagógico e a transformação dos sujeitos, o que demonstra que o processo formativo cria um novo perfil de profissional.

Também elencaram-se os pontos positivos e negativos do PARFOR, que apesar de ter uma repercussão boa no desenvolvimento do senso crítico, mudança de prática pedagógica, oportunidade de ingresso ao ensino superior, precisa ser reaviado em alguns pontos considerados negativos pelos sujeitos desta pesquisa, como o aceleramento do curso e carências de recursos gráficos como apostilas.

Por tudo isso, nota-se que o PARFOR tem transformado a realidade de muitos professores, mas, partindo do principio de que todo plano é flexível acredita-se que enquanto política pública, o PARFOR necessita ser redimensionado, efetivar a legislação não é tão mais importante do que oferecer mecanismos facilitadores no decorrer do processo formativo. Assim, com base neste processo investigativo concluímos que os acadêmicos de pedagogia tiveram muitas conquistas com a implantação do PARFOR, porém é preciso ainda proporcionar condições objetivas para que o professor possa usufruir de conquistas muito mais concretas que o fortaleçam em seu processo formativo, entre estas melhores salários e maior apoio e incentivo por parte das secretarias de estado e município.

\section{REFERÊNCIAS}

[1]. BRASIL. Ministério da Educação. Lei no 9394/96, Lei de Diretrizes e Bases da Educação Nacional. Diário oficial da República Federativa do Brasil Brasília, DF, 1996.

[2]. BREZZINSKI, Iria. GARRIDO, Elsa. Análise dos trabalhos do GT formação de professores: o que revelam as pesquisas de 1992-1998. Revista Brasileira de Educação, n.18, pp. 82-100, 2001.

[3]. COELHO, I. M. Formação do educador: dever do Estado, tarefa da Universidade. In: BICUDO, M. A. V.; SILVA JÚNIOR, C. A. (Org.). Formação do educador. São Paulo: Fundação Editora da UNESP, 1996.

[4]. DEMO, Pedro. Educação pelo avesso: assistência como direito e como problema. São Paulo: Cortez, 2000.

[5]. ESTEVE, José M. O mal-estar docente: a sala de aula e a saúde dos professores. Bauru: EDUSC, 1999.

[6]. FREIRE, Paulo. Pedagogia da autonomia: saberes necessários à prática educativa. 43 ed. São Paulo: Paz e Terra, 2011.

[7]. FREITAS, Helena Costa Lopes de. A reforma universitária no campo da formação dos profissionais da Educação Básica: as políticas educacionais e o movimento dos educadores. Educação \& Sociedade, Campinas, v. 20, n. 68, pp.17-43, dez, 1999.

[8]. . Formação de professores no Brasil: 10 anos de embate entre projetos de formação. Educação \& Sociedade, Campinas, v. 23, n. 80, pp.136-167, set, 2002.

[9]. MORAES, Roque; GALIAZZI, Maria do Carmo. Análise textual discursiva. 2 ed. rev. Ijuí : Unijuí, 2011.

[10]. GARCIA, C. M. A formação de professores: novas perspectivas baseadas na investigação sobre o pensamento do professor. In.: NÓVOA, A. (coord.) Os professores e a sua formação. Tradução de Graça Cunha, Cândida Hespana, Conceição Afonso e José A. S.Tavares. Lisboa: Dom Quixote, 1995.

[11]. _ _ _ _ _ Formação de professores: para uma mudança educativa. Porto: Porto Editora, 1999.

[12]. GATTI, Bernardete A. Formação de professores e carreira: problemas de movimento e renovação. 2. ed. Campinas: Autores Associados, 2000.

[13]. __ Análise das políticas para formação continuada no Brasil, na última década. Revista Brasileira de Educação, v. 13 n. 37, pp 57-70, jan./abr. 2008.

[14]. Bernardete A.; BARRETO, Elba S. S. Professores do Brasil: impasses edesafios. Brasília: UNESCO, 2009

[15]. GIL, Antônio Carlos. Como elaborar projetos de pesquisa. 4 ed. São Paulo: Atlas, 2008.

[16]. GÓES, P. Aspectos administrativos da educação pós-graduada no Brasil. Revista Brasileira de Estudos Pedagógicos, Brasília, DF, v. 58, n. 128, p. 224-231, 1997.

[17]. IMBERNÓN, Francisco. Formação docente e profissional: Formar-se para a mudança e a incerteza. São Paulo: Cortez, 2011. 
[18]. Formação continuada de professores. Porto Alegre: Artmed, 2010.

[19]. HAMBURGER, E. Para que pós-graduação? Encontros com a civilização brasileira, Rio de Janeiro: Civilização Brasileira, 1980.

[20]. MASSETTO, Marcos Tarciso. Didática: A aula como centro. São Paulo: FTD, 1997.

[21]. MINAYO, M. C. de S. O desafio do conhecimento: pesquisa qualitativa em saúde. 4. ed. São Paulo, 1995.

[22]. NUNES, L.C. Análise da política de Pós-Graduação no Brasil. Dissertação (Mestrado) - Faculdade de Educação, Universidade Federal do Rio de Janeiro, Rio de Janeiro, 1978.

[23]. NÓVOA, Antônio. Os professores e sua formação. 2 ed. Lisboa: D. Quixote, 1992.

[24]. SACRISTÁN, J. G.; PÉREZ GÓMEZ, A.I.; Compreender e transformar o ensino. Artmed, 1999.

[25]. SCHEIBE, Leda. Formação de Professores: Dilemas da Formação Inicial a Distância. Dissertação (Mestrado) Universidade Federal de Santa Catarina- UFSC, 2006.

[26].

SINISCALCO, M. T. A statistical profile of the teaching profession. Geneva: International UNESCO, 2002.

[27]. SERRANO, Maria Glória Perez. Investigación-acción: aplicaciones al campo social y educativo. Madrid: Dykinson, 1990.

[28].

SOUSA, Maria Goreti da Silva. A formação continuada e suas contribuições para a profissionalização de professores dos anos iniciais do ensino fundamental de Teresina- PI: revelações a partir de histórias de vida. São Paulo: Cortez, 2008.

[29]. TRIVINOS, Augusto Nibaldo Silva. Introdução à pesquisa em Ciências Sociais: a pesquisa qualitativa em educação. 1 ed. 16. reimpr. São Paulo : Atlas, 2008. 


\section{Capítulo 12}

\section{Professor homem na educação infantil: O que eles têm a dizer sobre sua formação inicial?}

\section{Luciano Gonçalves Teodoro \\ Gisela do Carmo Lourencetti}

Resumo: Quando pensamos em educação infantil, quem historicamente desempenhou o exercício profissional com a criança pequena foi a mulher. Transitando da esfera da assistência social para a educação, fez-se necessário pensar em uma adequada formação profissional que desse conta de um segmento tão peculiar, levando em consideração a tríade cuidar-educar-brincar. 0 estranhamento surge quando o homem passa a atuar nessa seara educacional, pois dele não é esperado sensibilidade e criação de vínculo com crianças. Para o presente trabalho, realizamos uma entrevista semiestruturada para "ouvir" a atuação docente do professor homem que atua na educação infantil. 0 presente artigo tem como objetivo identificar a importância da formação inicial para atuar na educação infantil. Os resultados apontam que essa formação deixou falhas, pois não adentrou nas especificidades da criança pequena: ademais, o curso de Pedagogia é muito teórico e não oferece subsídios para a realidade que o futuro professor encontrará ao assumir uma sala de aula.

Palavras-chave: Professor homem; educação infantil; trabalho docente. 


\section{INTRODUÇÃO}

0 presente trabalho, que é parte de uma dissertação de mestrado, tem como objetivo analisar as opiniões de professores homens sobre a formação inicial que receberam para o exercício do magistério com crianças da educação infantil.

No histórico da educação infantil, quem historicamente ficou responsável em educar as crianças foi a mulher (BRUSCHINI; AMADO, 1988). E essa opção deve-se a biologia: como ela gerou a criança, por extensão, pode levar o que ensina em casa para o espaço escolar. Não precisa de formação profissional, a maternidade dá à mulher as condições de desempenhar o papel de professora. Ademais, foi o magistério ao longo do tempo que propiciou à mulher um espaço de atuação fora da esfera doméstica (BRUSCHINI; AMADO, 1988).

Ao longo do tempo, a educação infantil transitou de um serviço assistencial, em que não havia necessidade de formação específica para atendimento das crianças, faziam-se necessárias pessoas para guarda e alimentação das mesmas, enquanto os membros da família saiam para trabalhar, para um serviço centrado em ações de cuidado-educação, em que ambas não se separam. 0 profissional que atua nesse segmento precisa ter uma sólida formação inicial para assumir uma sala de aula, além de estimular essa criança no desenvolvimento de suas habilidades e das várias dimensões que a compõe (CERISARA, 1999, p. 16).

Na formação do profissional que trabalhará com crianças desse segmento educacional a tríade cuidareducar-brincar não deve ser esquecida. Por não se separarem e seus momentos intercruzarem, o professor deve oportunizar momentos de interação (adulto-criança e criança-criança), socialização e acesso aos bens culturais produzidos historicamente pela humanidade (KRAMER, 1999). Ademais, como a criança está construindo sua autonomia e depende do adulto em muitas situações (ABRAMOWICZ; WAJSKOP, 1999) esse profissional tem de ser formado tendo como base "os conhecimentos derivados da psicologia, antropologia, sociologia, medicina etc. possam ser de grande valia para desvelar o universo infantil" (BRASIL, 1998, 22) para saber que tipo de atendimento será ofertado a criança.

Pensando no magistério enquanto opção profissional, o que dificulta tal escolha é por não figurar-se enquanto financeiramente viável. Outra ocupação ele terá de ter para complementar a renda auferida dando aula (CARVALHO, 1998). Enquanto espaço social, a escola revela cotidianamente modos de viver de homens e mulheres; e mais, mostra a criança - no nosso caso, a educação infantil - que apenas a mulher pode educá-la e instruí-la. Para Scott (1995) o modo como homens e mulheres se inserem em contextos profissionais é dado pela cultura, que desconsidera o domínio da técnica para poder trabalhar. 0 que pesa, infelizmente, é a questão biológica que diferencia homens e mulheres e como eles serão recebidos em seus locais de trabalho.

A chegada do professor homem a esse ambiente predominantemente feminino é cercado de estranhamento (SAYÃO, 2002), já que não se espera do homem que desempenhe uma profissão que exige afetividade e fino trato com as crianças (CRUZ, 1999; RAMOS, 2011). Assim, temos uma divergência em relação ao que envolve o papel da professora, pautado no carinho e na paciência (HENTGES; JAEGER, 2012), isto é, homens e mulheres atuam profissionalmente a favor, ou contra, o ideário que ronda a profissão.

Estar em uma sala de aula de educação infantil impõe ao professor homem dois tipos de estágio: há o estágio probatório, de modo formal e baseado em legislação específica que disciplina o período que o professor fica sob avaliação dos seus superiores; o segundo tipo é o estágio comprobatório (RAMOS, 2011) em que o professor, sob a supervisão velada da comunidade escolar, tem de mostrar que domina a sala de aula e os conteúdos pedagógicos para trabalhar com as crianças da educação infantil.

A literatura aponta que ocorre uma pressão para que o professor homem assuma postos de comando fora da sala de aula, vá trabalhar na burocracia educativa e assuma sala de aula que tenha crianças mais velhas (CARVALHO, 1998). As únicas ocupações permitidas para o homem desempenhar na esfera escolar são: zelador, segurança, coordenador e direção. 0 que as une é a distância que o profissional terá do corpo infantil.

Levando em consideração uma docência masculina encontraremos um desvencilhar do fazer feminino, que se assenta em duas ações: a primeira, consiste na realização de atividades pedagógicas que exigem força física (CARVALHO, 1998); e a segunda, em uma questão levantada por Jensen (1993) que é um maior contato com as crianças. Se a criança fala com o corpo, nada mais justo do que estar em contato com ele. 
Ao pensarmos na formação inicial do futuro professor da educação infantil, não dá para esquecer que a capacidade de fantasiar e criar cultura (KRAMER, 1999) que a criança possui precisa amparar a elaboração de um projeto pedagógico que supere o ambiente de origem da criança e o professor consiga refletir sobre a prática pedagógica que ampara teoria e prática em sua formação (REGO; MELLO, 2002).

Defendemos uma formação inicial que dê subsídio ao futuro profissional para conhecer o contexto em que a unidade escolar está inserida, bem como a concepção de infância em voga; ademais, que esse profissional entenda a educação infantil como a inserção da criança no universo dos bens culturais produzidos pela humanidade (KRAMER, 1999) e faça com que essa criança construa sua autonomia para cuidar de si e da sociedade em que reside.

\section{METODOLOGIA}

Ao entrarmos em contato com a prática dos professores homens que atuam na educação infantil, pareceunos que a abordagem de pesquisa qualitativa era a mais adequada por oferecer dados que, para Bogdan $\&$ Biklen (1994, p. 16), são "ricos em pormenores descritivos relativamente a pessoas, locais e conversas, e de complexo tratamento estatístico". E mais, a pesquisa é descritiva e analítica por resgatar o que pensa esse professor sobre sua prática. Assim, entenderemos como o professor vivencia a profissão escolhida.

Nesse sentido, para a coleta de dados, optamos pela realização de entrevista semiestruturada por considerar que ela dá "voz" ao professor homem, permite que se chegue mais próximo ao cotidiano da sala de aula e possibilita conhecer como os professores homens desempenham seu trabalho na educação infantil. Também possibilita que os professores homens explicitem como eles compreendem sua atuação docente.

Foi feito contato com a Secretaria de Educação de um município de grande porte do interior do estado de São Paulo para sabermos a quantidade de homens e mulheres atuando como professores de educação infantil. De posse dessa informação, entramos em contato com a unidade escolar em que os profissionais homens trabalhavam para agendar um horário que calhasse com o horário do pesquisador. Uma triste situação observada é que a própria Secretaria desconhece o local de trabalho de alguns professores, visto que, em alguns casos, na escola informada o professor não trabalhava mais lá.

Quatorze entrevistas foram realizadas e gravadas com professores, na sequência foram integralmente transcritas. 0 tempo médio de atuação no magistério da educação infantil desses professores é de sete anos.

Após a realização das entrevistas, iniciamos o processo de análise. Primeiro fizemos uma leitura atenta das transcrições das mesmas. Em seguida, procuramos pontos em comum, criando categorias para análise. Por último, dividimos as categorias para melhor analisar os dados. Percebemos que o fio condutor das entrevistas escolhidas para análise, cinco dentre as quatorze, está em notarmos que boa parte do trabalho realizado está assentado em práticas pedagógicas dotadas de senso comum.

\section{RESULTADOS}

Ao estudarmos homens, percebemos que eles falam pouco e de maneira objetiva. Para extrairmos mais informações, ou entendermos melhor uma ideia, fazia-se necessário aprofundar o questionamento feito anteriormente.

Para responder aos objetivos da pesquisa, analisaremos as respostas de cinco professores sobre um ponto importante do roteiro de entrevista: a formação inicial deu subsídios para a realização de um bom trabalho na educação infantil, quando do ingresso nesse segmento educacional?

Se foi satisfatória, isso? Ela deu um aporte, uma bagagem, digamos assim superficial, não aprofundou. Tocou na questão da legislação, mais assim pontualmente em algumas questões, a gente estudou um pouco de história da infância e não aprofundou, não me tornou um especialista na área, não me preparou, me deu uma bagagem superficial, assim digamos. (P1)

Inicialmente já percebemos que o termo usado, satisfatório, remete a uma formação que deixou lacunas. Assim, fica a sensação de incompletude, de assumir uma sala de aula com o pouco que a formação ofertou. Gatti (2009, p. 95), quando trata da formação do futuro professor, aponta a inexistência de "inovações e avanços" que possam eliminar o satisfatório e inserir a contribuição do formando enquanto partícipe do 
que acontecerá com seu futuro que está em construção.

Isso parece se confirmar que em seguida quando ele fala da superficialidade ofertada na formação inicial. Campos (2008, p. 127) deixa claro que "os currículos de formação de professores raramente abordam questões específicas", não formando um professor que compreenda o que diferencia as crianças ao longo de suas trajetórias escolares. A necessidade de cada faixa etária é relegada a questões mais genéricas, não especializando o professor para atende as especificidades das crianças da educação infantil (CERISARA, 1999). E mais, essa superficialidade insere no mercado de trabalho um profissional que desconhece o saber-fazer do contexto educativo em que trabalhará.No tocante a legislação, também deixou a desejar. Imaginamos que ele assumiu o magistério sem se dar conta que a legislação confirmou a educação infantil como porta de entrada da educação básica (RAMOS, 2011), bem como a sua importância para os demais níveis educacionais. Um grande avanço trazido pela legislação é a formação a ser ofertada ao futuro professor, que deve acontecer em nível superior, caminhando na mesma direção dos demais níveis educacionais. É nesse momento que a criança começa a tomar contato com os bens culturais produzidos pela humanidade, somado com a tríade que fundamenta o trabalho docente na educação infantil que é cuidar-educar- brincar, que um professor bem qualificado contribui para o desenvolvimento da cidadania dessa criança.

Ao não formar o especialista em educação infantil o Curso de Pedagogia esquece das experiências educativas que cada nível oferece. Na generalização, quem sai perdendo é a criança visto que a particularidade da educação infantil não é contemplada na formação inicial.

Entendemos que a necessidade educativa de cada momento histórico será dada pelo modo que a sociedade entende a importância do tipo de profissional para trabalhar com a criança da educação infantil, e que não fique preso a aspectos femininos (SAYÃO, 2002) em que apenas a mulher - por ter gerado uma criança - é o gênero mais apto para instruir crianças pequenas (BRUSCHINI; AMADO, 1988). Assim, a interlocução entre teoria e prática advém da formação em nível superior em que a história da infância é estudada ao mesmo tempo que outras disciplinas escolares, intercalando com o estágio que é o momento em que teoria e prática mostram ao professor o motivo da ação e/ou comportamento de determinada criança.

É importante conhecer a parte específica da educação infantil, mas também é preciso você sentir preparado, você sentir que é isso que você quer fazer. Com certeza, estudo, aperfeiçoamento, ir sempre atrás, aprimorar sua prática, ler, conversar mesmo, fazer cursos, assistir palestras, assistir vídeos, tem internet aí que tem tantos materiais bons, materiais disponíveis gratuitamente. Mas há sempre aqueles que resistem a buscar o novo. Bom, a teoria principalmente, porque ela diferencia muito do ensino fundamental onde nós trabalhamos a questão do conhecimento, alfabetização, leitura. Aqui, nós trabalhamos bastante o lúdico, os jogos, a fantasia para criança. (Pergunto o que ele entende por lúdico) as brincadeiras, trazer o conhecimento da criança a partir das brincadeiras. (P2)

0 professor P2 cita a parte específica da educação infantil que a formação inicial precisa subsidiar para que o futuro professor assuma uma sala de aula. Mas ao não explorar essa especificidade, compreendemos ser apenas um discurso descolado da realidade já que não detalha mais o que diferencia a educação infantil dos outros níveis educativos. E mais, esquece que a integração da tríade cuidar-educar-brincar articula desenvolvimento infantil, contexto educacional em que a unidade escolar está inserida e que a sociedade espera da educação infantil.

Apresenta para o debate questões de ordem interna - sentir preparado e assistir palestras - para desempenhar um bom atendimento às crianças, ou seja, fala do estímulo individual para que ocorra uma boa prática educacional (IMBERNÓN, 2006). Essas questões têm de estar ancoradas em uma formação que contextualize o que é ser criança ao mesmo tempo em que subsidie o professor para seu início na docência. 0 perfil que a formação inicial para atuar na educação infantil exige é de um profissional que tenha na integração entre atos de cuidado e educação, sem pensar em um sendo mais importante que o outro, o pilar de sustentação da atual profissional (CAMPOS, 1994).

Elenca a tecnologia como um novo meio para a formação do professor. Essa nova ferramenta potencializa a formação inicial, desde que o professor seja partícipe do processo que está ocorrendo com ele. Para o bom uso da tecnologia apenas professores bem formados para elevar a aprendizagem dos alunos. Ao 
mesmo tempo, temos a contradição em face da remuneração percebida pelo profissional obrigando-o a arcar com os recursos tecnológicos (REGO; MELO, 2002) para a sua formação e para ofertar uma aula diferente ao seu aluno. Se o salário é fator preponderante para o investimento profissional, seu poder de compra dirá o quanto o professor investirá em tecnologia.

Pontua a diferença entre o ensino fundamental e a educação infantil, mas esquece que um subsidia o trabalho do outro. Ademais, como a criança avança na escolarização um nível contribui para o processo de construção da autonomia intelectual da criança e de sua autonomia perante a sociedade (ABRAMOWICZ, A.; WAJSKOP, G., 1999). Como fase singular, e não preparatória para a alfabetização (FRANGELLA, 2009) que acontece no ensino fundamental, a educação infantil precisa estar estruturada para que a criança compreenda sua presença em um seio social mais amplo; e tudo começa com a vida familiar e escolar.

Finaliza trazendo o lúdico como parte importante da educação infantil. Infelizmente, não explica no que o lúdico contribui para o desenvolvimento da criança da educação infantil. Temos uma visão do senso comum, um brincar pelo brincar. Um brincar desprovido de ação pedagógica. Podemos inferir que partir do que a criança já sabe a brincadeira funciona como meio para impulsionar o aprendizado da criança, desde que esse conhecimento seja significativo para a criança (KRAMER, 1999).

Não, não acho que é(sic) necessário fazer uma especialização para trabalhar com criança pequena. Eu acho que a gente estuda na graduação de pedagogia, se você estuda mesmo e faz os estágios e tal, já te dá uma base para trabalhar com isso. $\mathrm{O}$ estágio te coloca em contato com a vida profissional real, entendeu. Ele coloca através do estágio que você vai pegar a teoria e transformar em prática, ou assimilar na prática. (P3)

O professor P3 acredita que a graduação em Pedagogia, que oferece uma formação generalista ao futuro professor, dá sustentação para a realização de um bom trabalho. Ele entende que a necessidade das crianças, independente de sua faixa etária, o curso de Pedagogia proporciona uma boa base para realizar um trabalho pedagógico a contento. Nesse quesito, Frangella (2009) entende que a infância exige sua compreensão enquanto momento de elaboração de um projeto educativo que entenda que cada faixa etária necessita de seu entendimento. Discordamos do professor acima, pois se na educação infantil a dependência do adulto é marcante, no ensino fundamental - em um processo de autonomia que está em construção - ela consegue realizar algumas ações sozinha, isto é, o processo de aquisição de conhecimentos contribui para que a criança possa participar do mundo social de maneira a ser ouvida.

Ao trazer o estágio enquanto campo de desenvolvimento profissional, o professor aponta um processo de assimilação da teoria com a prática. Assim, o estágio subsidia o ingresso do professor em sala de aula ao mesmo tempo que mostra como a teoria acontece na prática e como a prática pode orientar a teoria no entendimento de como determinadas ações educativas aconteceram. Deixou no ar o sentimento de que a formação inicial patina na junção das duas abordagens, já que elas determinaram o posicionamento do professor diante do fenômeno educativo que acontece na sala de aula da educação infantil.

Formação específica significa disciplinas específicas (digo uma pedagogia da educação infantil) pedagogia da educação infantil em um curso único? (pensativo) Eu acredito que sim, mas aí a gente tem que pensar nas diversas fases da educação infantil: berçário tem algumas demandas específicas eu acredito. E aí, de certa forma, entra uma dificuldade, uma resistência, eu não quero adiantar as coisas, mas devido a essa especificidade, por exemplo, troca de fraldas, é algo que para a comunidade escolar, muitas vezes para os pais gera um certo temor por ser homem, mas voltando: noções aprofundadas inclusive área de enfermagem, reconhecer certos estados da criança, manifestações de algo que você tem de levar para os pais. Eu acho que por envolver o cuidar, e tem essa diferença entre educar e cuidar né, e muitas vezes você tem que estar atento a tudo, inclusive a tipo de manifestação da criança, e a disciplina nessa área ajudaria. Eu acredito, porque a gente acaba entrando na prática e vai tudo assim (gesto com a mão) aí você pergunta para o colega isso aqui como é que eu faço, tem de perguntar tudo para o colega, pelo menos a minha formação inicial não me deu nada nesse sentido. A formação inicial ajudou, mas se ela assegura, não assegura. Tem diversos outros componentes para poder desenvolver um bom trabalho, e eu acredito que estou (sic) no caminho ainda, procurando desenvolver um bom trabalho, mas muita coisa minha formação não dá (sic) 
especialmente em termos de prática, que é o drama de muitas universidades. (P4)

O professor P4 acredita que uma pedagogia da educação infantil faria toda diferença, e acreditamos que essa pedagogia fugiria das práticas pedagógicas desenvolvidas no ensino fundamental, que desconsideram o brincar e a imaginação como ingredientes para o desenvolvimento psicossocial da criança, além de fonte de aprendizado.

Fala de si e não explicita o que a formação inicial não assegurou para iniciar o seu trabalho na educação infantil. Ao fazerem um estudo sobre as diversas políticas docentes existentes no Brasil Gatti, Barreto e André (2011) apontam que muitos cursos de formação de professores, em nosso caso, a Pedagogia, oferecem uma formação genérica e não aprofundam em uma determinada área da educação básica. Ainda, boa parte da carga horária desses cursos foca o entendimento dos problemas que o futuro professor encontrará em sala de aula, mas não ofertam conteúdos para desenvolver a prática profissional que o futuro professor deverá adotar ao assumir uma sala de aula para resolver os problemas oriundos dessa realidade.

Acende o debate sobre o professor homem na educação infantil quando desenvolve atos de cuidado (HENTGES; JAEGER, 2012). Por ser algo sagrado, apenas a mulher pode tocar, em decorrência da maternidade, e da construção social de gênero (SCOTT, 1995) que dirá que a mulher é a mais preparada para cuidar da criança, causando surpresa homem atuando nesse segmento educacional, o corpo infantil tem de ser escondido desse homem (CRUZ, 1999). Ficou no senso comum esse debate, não aprofundou sobre a importância de um profissional bem formado que sabe a interação que ocorre quando da troca de fraldas, ou da estimulação que pode ocorrer potencializando o desenvolvimento infantil.

A formação do professor e a teoria utilizada para análise mostram que a formação está descolada da realidade e forma profissionais que não tem cabedal científico para pensar estratégias para resolver os problemas que surgem em sala de aula. Ainda o mesmo professor, ele acredita que outros campos do conhecimento, a área de enfermagem, por exemplo, podem contribuir para a formação do futuro professor. Os Referenciais Curriculares Nacionais para a Educação Infantil, RCNEI, (1998) nos ensinam que o espaço escolar, na prática pedagógica, comporta a atuação de diversas áreas do conhecimento. Concordamos com essa ideia, já que outras áreas nos farão perceber a criança na totalidade e qual a melhor intervenção a ser realizada quando determinados fatos acontecem, como exemplo, podemos citar, o engasgo de uma criança.

Uma dimensão chama a atenção: ao ir para a prática acaba ficando pouco tempo para aprofundamentos teóricos da atuação profissional, isto é, a prática alimenta a prática e o professor fica desguarnecido de conhecimento científico que embase o desenvolvimento de atividades educativas para as crianças. A prática tem de funcionar como alavanca para estruturar novos conhecimentos e melhorando as ações pedagógicas desenvolvidas até então.

A com certeza precisa, e como. Eu mesmo, porque fiz o magistério, hoje principalmente eu vejo que aquele magistério antigo, que a gente fez, as vezes preparou a gente melhor do que tem certas pedagogias (faculdades) hoje que forma professor. Porque as vezes, assim, a gente tem colegas, por exemplo, que vem de formação nova e que não sabe lidar nessa área, entendeu; as vezes, tem educador que não sabe como que troca uma fralda. E mulher, hein! Nossa, e como foi, depois que a gente passa a exercer a profissão que a gente vê a bagagem trouxe de lá para cá. Eu penso assim: que muitos hoje que chega (sic), a maioria tem um despreparo que a gente enxerga logo de cara. (Pergunto onde está a falha do curso de pedagogia) Não, eu falo assim justamente o que eu tô (sic) acabando de falar trabalha-se muito o teórico e a prática quase nada. Tem gente que chega aí e não sabe nem trocar uma fralda duma (sic) criança. (Digo: é capaz de sair correndo então?) Oh, se não (risos), a criança faz vômito, faz coco, é perigoso dar ânsia de vômito na criança (risos) (como falávamos da professora, entendo que ele tenha dito palavra errada, em vez de criança era para ter dito professora).(P5)

De um modo bem sucinto, acredita que uma pedagogia da infância seja importante para poder diferenciar ritmos, aprendizagens e necessidades de cada segmento educacional. E o imperativo é que a educação infantil tenha uma proposta pedagógica que contemple "um único objetivo....processo de cuidado e educação" (DIDONET, 2001, p. 21) e a criança tenha seu direito a um espaço que a ela pertence, com profissionais com uma sólida formação inicial e boa remuneração. 
Percebemos uma defesa da antiga formação ofertada pelo Ensino Médio, em uma habilitação específica para o magistério. Critica a atuação de algumas profissionais, formadas em nível superior, via Curso de Pedagogia, ao citar a troca de fraldas. Duas observações precisamos fazer: a) o espaço de formação do futuro professor precisa passar por uma reformulação em que uma nova concepção de formação leve em consideração o contexto em que a escola está inserida, sem desconsiderar o momento histórico vivido (REGO; MELLO, 2002); b) o importante é situar o momento em que a troca de fraldas ocorre. A troca pela troca não estimula o desenvolvimento infantil, mas se estiver dentro de uma prática pedagógica objetiva contribuirá e muito para o desenvolvimento dessa criança.

Não sentimos avanços teórico-científicos no trecho acima, ele centra sua fala em repetir clichês e não aponta no que uma boa formação inicial contribui para o aprendizado infantil dos bens culturais produzidos pela humanidade.

No cruzamento das cinco entrevistas encontramos pontos de convergência. Primeiro, uma forte crítica a formação inicial, que não articula a formação teórico- científica com a prática docente, fazendo com que o futuro profissional não veja nexo entre a realidade em que atuará e a formação que está recebendo; segundo, pouco se aborda legislação educacional, assim o futuro professor não sabe direitos e deveres da família, da escola e dele enquanto profissional; terceiro, a ideia de que uma pedagogia da infância faz diferença para trabalhar na educação infantil; por último, sentimos falta de um aprofundamento teórico para entender o motivo de adotarem determinadas práticas, ou seja, uma presença marcante do senso comum nas respostas dadas. Desse modo, ganha corpo um discurso que considera vocação trabalhar com crianças - e qualquer remuneração está de bom tamanho - e não a necessidade de investimento maciço na formação do professor.

O que diferencia as análises foram os seguintes pontos: a) a contribuição de outras áreas do conhecimento na formação do futuro professor, assim esse profissional entenderá a criança de modo integrado; b) apenas um professor abordou a questão de gênero, evidenciando o estranhamento que a participação masculina causa nesse segmento educacional; não comentaram se há diferença ser homem ou mulher e trabalhar com crianças pequenas (JENSEN, 1993).

Infelizmente, um distanciamento do conhecimento científico estudado na formação inicial apareceu nas falas dos professores, indicando que teoria e prática precisam ter os laços estreitados para que no desempenho profissional esse professor ofereça experiências significativas às crianças

\section{CONCLUSÕES}

O que fica da formação inicial é uma crítica ao modelo ofertado pelo Curso de Pedagogia, muito teórico e afastado da prática cotidiana de sala de aula; assim, o professor assume uma turma de crianças e não sabe como trabalhar já que o que a universidade ensinou está descolado da realidade que ele vivencia. Outro professor lembrou da importância da contribuição de outras áreas do conhecimento para a compreensão do fenômeno educativo que acontece na interação professor-aluno, já que a criança precisa ser compreendida em sua complexidade.

Consideramos delicada a situação quando o professor cita que a formação ofertada pelo Curso de Pedagogia é suficiente para trabalhar com crianças da educação infantil ao desconsiderar a especificidade requerida para o desenvolvimento de ações pedagógicas que faça com que a criança se apodere do espaço social existente ao seu redor. Tal especificidade reside na tríade cuidar-educar-brincar. Esquecendo da especificidade o trabalho docente fica desguarnecido da contribuição científica sobre como a criança aprende e interage com o meio em que está inserida.

Ao terminarmos o presente trabalho fica a sensação de que a aspereza masculina é um dado da cultura e que os professores homens se sentem realizados ao perceberema evolução no aprendizado das diversas linguagens que a criança mostrou ao longo do ano letivo.

\section{REFERÊNCIAS}

[1] ABRAMOWICZ, A.; WAJSKOP, G. Educação infantil: creches: atividades para crianças de zero a seis anos. $2^{\text {a }}$ ed. São Paulo: Moderna, 1999.

[2] BOGDAN, R.; BIKLEN, S. K. Investigação qualitativa em educação: uma introdução a teoria e aos métodos. Porto: Porto Editora, 1994. 
[3] BRASIL. Ministério de Educação e do Desporto. Referencial curricular nacional para educação infantil. Brasília: MEC, 1998.

[4] BRUSCHINI, C.; AMADO, T. Estudo sobre a Mulher e Educação: algumas questões sobre o Magistério. Cadernos de Pesquisa, n. 64, 1988.

[5] CAMPOS, M. M. Educar e cuidar: questões sobre o perfil do profissional de educação infantil. In: Por uma política de formação do profissional de educação infantil. Brasília: MEC, 1994.

[6] CAMPOS, M. M. Educar crianças pequenas: em busca de um novo perfil de professor. Revista Retratos da Escola, Brasília, v. 2, n. 2-3, jan./dez. 2008.

[7] CARVALHO, M. P. de. Vozes masculinas numa profissão feminina: o que têm a dizer os professores. Estudos Feministas, Florianópolis, v. 6, n. 2, 1998.

[8] CRUZ, E. F. Quem leva o nenê e a bolsa? O masculino na creche. In: ARILHA, M.; UNBEHAUM, S. G.; MEDRADO, B (orgs). Homens e masculinidades: outras palavras. São Paulo: Editora 34, 1999.

[9] FRANGELLA, R. deC. P. Educação infantil e a nstitucionalização da infância: entre a autonomia e a regulação. Teias, Rio de Janeiro, v. 10, n. 20, 2009.

[10] GATTI, B. A. Formação de professores: condições e problemas atuais. Revista Brasileira de Formação de Professores, v. 1, n. 1, maio/2009.

[11] BARRETTO, E. S. de S.; ANDRÉ, M. E. D. A. Políticas docentes no Brasil: um estado da arte. Brasília: UNESCO, 2011.

[12] HENTGES, K. J.; JAEGER, A. A. Relações de gênero, masculinidade e docência masculina. Disponível em: http://jne.unifra.br/artigos/4946.pdf

[13] IMBERNÓN, F. Formação docente e profissional: formar-se para a mudança e a incerteza. 6ª ed. São Paulo: Cortez, 2006.

[14] JENSEN, J. J. Homens em serviços de cuidado de crianças - um artigo para discussão. Comunicação apresentada no Seminário Internacional "Men as carers: towards a culture of responsability, sharing and reciprocity between genders in the care and upbringing of children". Ravena, Itália, 1993.

[15] KRAMER, S. O papel social da educação infantil. Revista Textos do Brasil, Brasília, Ministério das Relações Exteriores, 1999.

[16] RAMOS, J. Um estudo sobre os professores homens da educação infantil e as relações de gênero na rede municipal de Belo Horizonte - MG. Dissertação (mestrado) - Pontifícia Universidade Católica de Minas Gerais, Belo Horizonte. 2011.

[17] REGO, T. C.; MELLO, G. N. de. Formação de professores na América Latina e Caribe: a busca por inovação e eficiência. In: Conferência Internacional Desempenho dos Professores na América Latina: tempo de novas prioridades. Brasília, DF, 2002.

[18] SAYÃO, D. T. Relações de gênero na creche: os homens no cuidado e educação das crianças pequenas. G.T. Educação das crianças de 0 a 6 anos - G.T. 07, 25ํㅡㄹ Reunião Anual da ANPEd, Caxambu/MG, 2002.

[19] SCOTT, J. Gênero: uma categoria útil de análise histórica. Educação e Realidade, Porto Alegre, vol. 20, n. 2, jul./dez. 1995. 


\section{Capítulo 13}

\section{O livro didático como indicador de mudanças $e$ transformações no Ensino de Ciências}

\section{Edna Luiza de Souza \\ Nilson Marcos Dias Garcia}

Resumo: Apresenta resultados de pesquisa que buscou traçar um panorama da trajetória do livro didático de Ciências ao longo da história educacional brasileira tomando como pressuposto a conceituação de Choppin (2000) de que o passado desse recurso didático pode contribuir para explicar o presente e até orientar o futuro. No que se refere à trajetória do livro didático de Ciências, foi possível perceber uma forte articulação com as políticas públicas vigentes e que as discussões em função desse objeto da cultura escolar foi se tornando fundamental perante as novas perspectivas do cotidiano escolar. Verificou-se também que, embora tenha havido uma crescente produção e distribuição dos livros didáticos através do Programa Nacional do Livro Didático (PNLD), ainda é necessário um diálogo com os agentes que utilizam esse artefato em sala de aula, dada a dinâmica e a diversidade cultural presente na escola.

Palavras chave: livros didáticos, ensino de ciências, mudanças curriculares. 


\section{INTRODUÇÃO}

Uma das abordagens possíveis para se analisar a história da educação se estabelece pela trajetória do livro didático em diversos momentos em que esteve e ainda continua presente nas salas de aula. É inegável que do ponto de vista da escola, de acordo com Choppin (2000, p. 114), por revelar as "práticas sociais e os métodos de ensino de uma determinada época", o livro didático contribui no entendimento dessa instituição no seu cotidiano e nas normatizações que norteiam principalmente a estrutura curricular das disciplinas.

Ao reconstituir e compreender a caminhada histórica da elaboração da legislação da educação brasileira e relacioná-la com a presença dos livros didáticos é possível visualizar as transformações que ocorreram e assim reconhecer, nos dias atuais, suas contribuições e interferências na prática pedagógica. Nesse sentido esse trabalho busca caminhar através das mudanças educacionais e analisar a inserção do livro didático no contexto escolar para reconhecer as perspectivas de mudanças em sua elaboração e distribuição às instituições escolares.

\section{ENSINO FUNDAMENTAL E O LIVRO DIDÁTICO NO BRASIL}

Reconhecidamente, a primeira vez que a educação brasileira foi tratada de maneira global e nacional ocorreu na denominada Reforma Francisco Campos, realizada durante o Governo Provisório, nos fins de 1930, com a criação do Ministério da Educação e Saúde Pública, tendo como Ministro o Sr. Francisco Campos. (ROMANELLI, 1985, p. 131). Conforme essa autora, essa Reforma teve o mérito de promover, pela primeira vez, uma análise mais ampla da estrutura do ensino e, o que é mais importante, especificava orientações para todo o território nacional. Essas mudanças atingiram principalmente a organização do ensino superior no Brasil, mas também abordou questões sobre o ensino secundário.

Alguns anos depois, mas ainda no contexto dessa Reforma, a Constituição de 1934, registra, em seu artigo 150 ,

...a necessidade da elaboração de um Plano Nacional de Educação que coordene e supervisione as atividades de ensino em todos os níveis. São regulamentadas (também pela primeira vez) as formas de financiamento da rede oficial de ensino em quotas fixas para a Federação, os Estados e Municípios (Art. 156), fixando-se ainda as competências dos respectivos níveis administrativos para os respectivos níveis de ensino. (Art.150). (FREITAG, 1980, p.50)

Também é desse período a implantação da gratuidade e obrigatoriedade do ensino primário e a divisão do curso primário em Fundamental, com duração de quatro anos, e Complementar, com duração de um ano destinada a crianças de 7 a 12 anos. A organização curricular foi estabelecida pelo Decreto-lei no 8.529 de $2 / 1 / 1946$, que definia as seguintes disciplinas ou assuntos a serem abordados nesse nível de ensino:

Curso primário elementar:

I - Leitura e linguagem oral e escrita;

II- Iniciação à Matemática;

III- Geografia e História do Brasil;

IV- Conhecimentos gerais aplicados à vida social, à educação para saúde e ao trabalho;

V - Desenho e trabalhos manuais;

VI - Canto Orfeônico;

VII - Educação Física.

Curso primário complementar: Ao currículo anterior, a lei acrescentou, para esse curso, noções de Geografia Geral e História das Américas e Ciências Naturais e Higiene. (FREITAG, 1980, p.160).

Mudança significativa na educação brasileira foi sentida em 1961, com a Lei de Diretrizes e Bases da Educação Nacional (LDB) - Lei no 4.024, de 20/12/61, segundo a qual os Estados, desde que atendidas às linhas gerais apresentadas na lei, adquiriram autonomia para deliberar sobre questões de ensino. Apesar de ser apenas com a Reforma Francisco Campos que a educação brasileira assumiu caráter nacional, o mesmo não se pode dizer da preocupação com os livros didáticos a serem usados pelos alunos, pois diversas iniciativas já haviam sido tomadas nesse sentido nas primeiras décadas do século XX. 
Com a criação do Instituto Nacional do Livro (INL), em 1929, o estado iniciou o processo de integração do livro didático na educação brasileira. Em 1938 com o decreto-lei no 1.006 foi instituída a Comissão Nacional do Livro Didático (CNLD) e em seguida, através do decreto-lei no 8.460 de 26/12/1945, foi consolidada a legislação sobre as condições de produção, importação e utilização do livro didático.

No âmbito dos chamados "acordos MEC-USAID", acordos estabelecidos entre o Ministério da Educação (MEC) e a Agência Norte-Americana para o desenvolvimento Internacional (USAID), visando suprir as demandas da educação nacional (ROMANELLI, 1985, p. 196), em 1966 foi instituída pelo Decreto $n^{\circ}$ 59.355, de 4 de outubro, a Comissão do Livro Técnico e Livro Didático (COLTED), cujos efeitos, por estabelecer controle de publicação e distribuição de livros técnicos e didáticos, atingiriam todo o sistema de ensino nacional. (ROMANELLI, 1985, p. 213).

A partir de 1970 o INL passou a desenvolver o Programa do Livro Didático para o Ensino Fundamental (PLIDEF) e em 1976, pelo decreto no 77.107, o INL foi substituído pela Fundação Nacional do Material Didático Escolar (FENAME), cujos recursos passaram a ser administrados pelo Fundo Nacional do Desenvolvimento da Educação (FNDE). Segundo Oliveira et al (1997), "convênios estabelecidos entre a FENAME e as Secretarias Estaduais de Educação, obrigavam o governo federal a distribuir um determinado montante de livros ao alunado carente da rede oficial de $1^{\circ}$ grau". (p.64).

No que se refere à educação de crianças e jovens, ela foi reestruturada pela lei 5.692 de 11 de agosto de 1971, que ampliou as atribuições e a estrutura dos currículos de $1^{\mathrm{o}}$ e $2^{\mathrm{o}}$ graus, tornando-os compulsoriamente profissionalizantes, e estendeu a obrigatoriedade e a gratuidade dos livros didáticos para o Ensino Fundamental, abrangendo a faixa etária dos 7 aos 14 anos.

Em 1985, o Programa Nacional do Livro Didático (PNLD), que substituiu o PLIDEF, estabeleceu várias mudanças, como por exemplo:

- Indicação do livro didático pelos professores: os professores passaram a participar do processo de indicação do livro didático;

- Reutilização do livro;

- Extensão da oferta aos alunos de 1ำ e 2o série das escolas públicas e comunitárias;

- Fim da participação financeira dos estados, assumindo o controle do processo decisório pela Fundação de Apoio ao Estudante (FAE) e garantindo o critério de escolha pelos professores.

Através do PNLD houve uma maior participação dos professores na escolha dos livros, priorizados através das disciplinas de Comunicação e Expressão e Matemática e acesso às escolas da rede pública. 0 comprador dos livros produzidos pelas editoras direcionava-se ao MEC, acabando com o sistema de coedição e financiador das obras didáticas pelos estados (HÖFLING, 2006, p. 23). A efetivação do PNLD e a participação mais efetiva do governo federal foram concretizadas na Constituição Federal, que preconizava que

O dever do Estado com a educação será efetivado mediante a garantia de (...) VII - atendimento ao educando no ensino fundamental, através de programas suplementares de material didático-escolar, transporte, alimentação e assistência à saúde (art.208).

Em atendimento ao disposto nesse artigo, iniciou-se um processo gradativo de ampliação na aquisição e distribuição dos livros didáticos destinados aos alunos de $1^{\underline{a}}$ a $4^{\underline{a}}$ série da rede pública de ensino. No âmbito desse processo, visando promover a melhoria do livro didático que chegava à escola, em 1994 teve início a avaliação sistemática dos livros inscritos no PNLD, que redundou na seleção dos livros submetidos e a elaboração de Guia de Livros Didáticos, inicialmente para os livros de $1^{\underline{a}}$ a $4^{\underline{a}}$ séries.

Esse documento, elaborado por avaliadores das diferentes áreas, tinha como tarefa a explicitação dos critérios gerais e específicos de avaliação das disciplinas e como objetivo orientar os professores na seleção dos livros didáticos que deveriam ser adquiridos. 0 "Guia do Livro Didático", inicialmente criado para auxiliar a avaliação e a escolha dos livros de $1^{\underline{a}}$ a $4^{\underline{a}}$ séries do Ensino Fundamental, com o passar do tempo foi sendo estendido para todos os materiais selecionados e distribuídos para as escolas públicas. 
Em 1993, com a publicação do Plano Decenal de Educação para Todos, teve início a discussão, com a participação de educadores e representantes da sociedade civil organizada, a elaboração de diretrizes sobre a universalização do ensino. De acordo com Horikawa e Jardilin,

O Plano ressaltava a educação institucional pública como ambiente de realização da equidade social, que poderia elevar os patamares de cidadania, democratização e desenvolvimento do país. Caberia ao Estado, dentre tantas tarefas, promover ações que viabilizassem a elevação do nível de aprendizagem do aluno. Inseria-se, portanto, nessas diretrizes, não só o aprimoramento das características do livro didático, como também a formação do professor, no sentido de capacitá-lo e avaliar e selecionar o material, mediante uma análise criteriosa das necessidades e possibilidades de aprendizagem escolar em que atuava. (HORIKAWA e JARDILIN, 2010)

Essas discussões antecederam e subsidiaram a nova Lei de Diretrizes e Bases da Educação Nacional - LDB, de 20 de dezembro de 1996, que propôs, em seu artigo 29, que os currículos do Ensino Fundamental e Médio propiciem uma formação básica comum e uma parte diversificada aos estabelecimentos. A parte diversificada estabelece a possibilidade de valorização das características específicas de cada comunidade escolar, abrindo a possibilidade de que aspectos de manifestações culturais e o envolvimento da escola e da sociedade sejam contemplados como componentes curriculares.

Nesse mesmo ano iniciam-se as discussões sobre os Parâmetros Curriculares Nacionais - PCN, inicialmente com uma proposta para os quatro primeiros anos do Ensino Fundamental, agregando nas disciplinas tradicionais do currículo os temas transversais: meio ambiente, a educação sexual e a educação ética.

Nesse desenho de currículo, a busca de ressignificação dos conteúdos curriculares, para que melhor correspondam às demandas da população e da sociedade abrangente, procede de fora para dentro, ou seja, provém desses temas, que são elementos exteriores ao próprio tratamento epistemológico conferido às áreas do conhecimento escolar. (BARRETO, 2000, p. 36).

Através dos PCN há uma perspectiva de promover a elaboração de um currículo que contemple todos os níveis educacionais do país, com a finalidade de melhoria da qualidade da educação brasileira. Para essa qualidade são necessários investimentos em diferentes frentes, como formação continuada dos professores, salários dignos, plano de carreira e a qualidade do livro didático e outros recursos (PCN, 1997, p.14).

Decorrente desses novos encaminhamentos, gradativamente todo o Ensino Fundamental, da 1aa a $8^{\underline{a}}$ séries, foi sendo contemplado com a distribuição de livros de Alfabetização, Língua Portuguesa, Matemática, Ciências, Estudos Sociais, História. Nos anos seguintes houve também inclusão de dicionários, atlas, materiais específicos aos alunos com deficiência visual, material para EJA - Educação de jovens e adultos. Nesse novo período, com a extinção da FAE, em 1997, a responsabilidade pela política de execução do PNLD passou a ser realizada integralmente sob a responsabilidade do Fundo Nacional de Desenvolvimento da Educação (FNDE).

Em 2003, dando prosseguimento à política de distribuição de material didático aos alunos das escolas públicas, o PNLD foi estendido para o Ensino Médio e hoje contempla todas as disciplinas curriculares oportunizando dessa maneira um recurso didático para o processo de ensino-aprendizagem a todos os níveis de ensino da Educação Básica. Com a ampliação do Ensino Fundamental para nove anos, através da lei 11.114, de 2005, dentre as diversas mudança que ocorreram, merece destaque o artigo 40 da Resolução no. 7/2010, do Conselho Nacional de Educação e da Câmara de Educação Básica, que fixou as Diretrizes Curriculares Nacionais para o Ensino Fundamental de Nove Anos:

Art. 40 (Resolução no7) 0 atendimento escolar às populações do campo, povos indígenas e quilombolas requer respeito às suas peculiares condições de vida e a utilização de pedagogias condizentes com as suas formas próprias de produzir conhecimentos, observadas as Diretrizes Nacionais Gerais para a Educação Básica (RESOLUÇÃO no 7/2010). 
Para encaminhar o acima prescrito, uma das ações do PNLD referente ao atendimento escolar para essas populações diz respeito à escolha do livro didático específico para a Educação do Campo, anos iniciais, a partir de 2013. Essa escolha foi composta pelos seguintes componentes curriculares: Letramento e Alfabetização, Língua Portuguesa, Matemática, História, Ciências e Geografia. O Programa coloca em evidencia a discussão sobre livros didáticos específicos para determinados grupos sociais, que mantém tradições culturais que transcendem gerações e ainda persistem e se adaptam às transformações do mundo global.

\section{ENSINO DE CIÊNCIAS NO ENSINO FUNDAMENTAL E OS LIVROS DIDÁTICOS}

No campo específico da disciplina de Ciências há um histórico das mudanças e transformações curriculares que influenciaram e ainda influenciam diretamente na organização dos conteúdos e na maneira de levar o conhecimento aos alunos.

Investigador da história do ensino de Ciências, Lorenz (1986), em estudo realizado sobre os livros didáticos e o ensino de Ciências na escola secundária brasileira no século XIX, constatou, analisando a documentação do Colégio Dom Pedro II, que os autores de livros adotados para as disciplinas de Ciências nesse colégio, modelo para o Brasil da época, foram quase exclusivamente franceses, donde é possível concluir que o modelo francês influenciava a prática docente escolar brasileira, em se tratando das disciplinas de física, química, cosmografia, astronomia, geologia, mineralogia, botânica, zoologia e higiene.

Essa situação sofreu mudança significativa nas décadas de 1950 e 1960 quando, decorrente de diversos projetos na Área de Ciências da Natureza desenvolvidos nos Estados Unidos, o ensino dessas disciplinas ensejou uma produção mais intensa de materiais didáticos brasileiros.

A partir de um levantamento das instituições nacionais criadas para desenvolver materiais didáticos desta área de ensino, como o Instituto Brasileiro de Educação, Ciência e Cultura (IBECC) e a Fundação Brasileira para o Desenvolvimento do Ensino de Ciências (FUNBEC), Barra e Lorenz (1986) discutem a produção de materiais didáticos de Ciências no Brasil, no período de 1950 a 1980. Os autores apresentam as influências culturais, econômicas, sociais e tecnológicas que modificaram a elaboração dos diferentes materiais didáticos, como apostilas, compêndios e livros didáticos e a visão do papel do aluno em relação aos conceitos científicos apresentados em sala de aula, constatando que os conteúdos abordados e a metodologia empregada pelos professores em sala de aula eram influenciados pelos materiais disponíveis nesse período.

Dentro da perspectiva curricular é interessante apontar que somente com a promulgação da Lei 5692/71 o ensino de Ciências tornou-se componente curricular obrigatório para todas as séries do Ensino Fundamental. Anteriormente a essa lei, essa disciplina foi obrigatória somente nos últimos anos ginasiais, e em 1961 esse ensino tornou-se obrigatório para os dois anos iniciais do ciclo ginasial, com a promulgação da Lei 4024/61.

Com a obrigatoriedade do ensino de Ciências para as séries iniciais do Ensino Fundamental, houve, segundo Selles e Ferreira (2004) "uma dependência dos professores pelos livros didáticos, na seleção e organização dos conteúdos, atividades e métodos de ensino". Segundo essas autoras, para muitos professores, os livros constituíam o único guia para a aprendizagem em sala de aula.

De acordo com Krasilchik (1987), na década de 1970, os currículos de Ciências brasileiros começaram a incorporar uma visão de ciência como produto do contexto econômico, político e social. Já na década de 1980, a renovação do ensino de Ciências passou a se orientar pelo objetivo de analisar as implicações sociais do desenvolvimento científico.

No final da década de 1990, após a LDB 9394/1996, os Parâmetros Curriculares de Ciências - PCN passaram a constituir o documento geral para indicar os fundamentos, objetivos, conteúdos e metodologia para o ensino nessa área, tendo em vista abranger todas as escolas do país. A finalidade do ensino de Ciências expressa nesse documento é "mostrar a Ciência como um conhecimento que colabora para a compreensão do mundo e suas transformações, para reconhecer o homem como parte do universo e como indivíduo." (BRASIL, 1997, p. 2). 
Os PCN ainda estabelecem que

Para o ensino de Ciências Naturais é necessária a construção de uma estrutura geral da área que favoreça a aprendizagem significativa do conhecimento historicamente acumulado e a formação de uma concepção de Ciência, suas relações com a tecnologia e com a sociedade. Portanto, é necessário considerar as estruturas de conhecimento envolvidas no processo de ensino e aprendizagem - do aluno, do professor, da Ciência. (BRASIL, 1997, p.31).

O ensino de Ciências a partir dos PCN passa a ganhar novas dimensões no seu entendimento como uma disciplina que possibilita uma aprendizagem com dimensão formativa e cultural (CARVALHO, 2004, p. 2). Nessa perspectiva, Delizoicov, Angotti e Pernambuco ponderam que,

Juntamente com a meta de proporcionar o conhecimento científico e tecnológico à imensa maioria da população escolarizada, deve-se ressaltar que o trabalho docente precisa ser direcionado para sua apropriação crítica pelos alunos, de modo que efetivamente se incorpore no universo das representações sociais e se constitua como cultura. (2009, p. 34).

Sendo parte de uma política mais ampla, os livros didáticos passam a ser elaborados a partir dos elementos curriculares presentes nos Parâmetros e Diretrizes, e devem oferecer condições para que os professores possam conciliar as normas vigentes com a realidade de sua escola, embora muitas vezes, devido às divergências curriculares regionais, haja dificuldade de selecionar livros que apresentem de maneira linear essas particularidades e possam contemplar de maneira satisfatória todas as determinações e propostas.

Devido a essa importância, e não sem justificativa, no meio educacional o livro didático tem sido objeto de investigação, envolvendo as diversas disciplinas e seus resultados têm sido registrados em artigos de periódicos e apresentados em eventos. Com a consolidação e crescimento da Área de Pesquisa em Educação em Ciências, muitas pesquisas têm sido realizadas a respeito dos livros didáticos dessa disciplina. Tais pesquisas têm resultado em trabalhos que são apresentados em eventos da área e publicados em periódicos, oferecendo à sociedade discussões a respeito do conteúdo desses livros, de sua escolha pelos professores e do seu uso por alunos e professores. Também têm sido frequentes trabalhos que discutem o processo de produção, avaliação e distribuição dos livros, principalmente a partir do crescimento de importância do PNLD no Brasil.

Vários estudos sobre LDs [livros didáticos] de disciplinas da área científica feitos no Brasil [...] constataram que predominam análises direcionadas a conteúdos conceituais ou metodológicos, ficando à margem das pesquisas os modos de inserção do LD [livro didático] no contexto escolar. (SILLOS e SANTOS, 2013, p.02-03)

Elementos da cultura escolar, os livros didáticos participam do contexto em que são elaborados e manuseados. Investigar a sua utilização ao longo do tempo em diferentes contextos permite compreender as transformações das políticas educacionais e quais os fatores são determinantes para sua efetivação e distribuição nas escolas públicas brasileiras.

\section{CONSIDERAÇÕES}

O estudo da história da educação brasileira tomando como referência os livros didáticos permite elaborar uma reflexão a respeito dos entraves e possibilidades gerados pelas ações normativas sobre as práticas pedagógicas desenvolvidas nas escolas públicas. Atores e sujeitos dessas ações, esses materiais pedagógicos sofrem e exercem influência sobre o trabalho dos professores e dos alunos no processo de ensino-aprendizagem.

Apesar dessa importância, percebe-se que os diversos aspectos relativos à produção, presença e uso do livro didático nas escolas ainda não estão sendo contemplados de maneira expressiva no diálogo de suas múltiplas funções e influências com a dinâmica escolar. 


\section{AGRADECIMENTOS E APOIOS}

A autora Edna Luiza de Souza registra o apoio da Capes pela bolsa de doutorado. 0 autor Nilson Marcos Dias Garcia registra o apoio parcial da Fundação Araucária.

\section{REFERÊNCIAS}

[1] BARRA, V. M.; LORENZ, K. M. Produção de materiais didáticos de Ciências no Brasil: período: 1950 a 1980. Ciência e Cultura, v. 38, n. 12, p.1970-1983, 1986.

[2] BARRETO, E.S.S. Tendências recentes do currículo do Ensino Fundamental no Brasil. In: BARRETO, E.S. S (org.). Os currículos do Ensino Fundamental para as escolas brasileiras. 2 ed. Autores Associados: São Paulo: Fundação Carlos Chagas, 2000.

[3] BRASIL. Parâmetros Curriculares Nacionais: ciências naturais / Secretaria de Educação Fundamental. Brasília: MEC/SEF, 1997.

[4] _ Resolução n. 7, de 14 de dezembro de 2010. Fixa Diretrizes Curriculares Nacionais para o Ensino Fundamental de 9 (nove) anos. Brasília, DF., 2010.

[5] _. Constituição (1988). Constituição: da República Federativa do Brasil. Brasília, DF: Senado Federal: Centro Gráfico, 1988.

[6] __. Lei de Diretrizes e Bases da Educação Nacional. Lei no 9394, de 20 de dezembro de 1996. Estabelece as diretrizes e bases da educação nacional. Brasília, DF, 1996.

[7] CHOPPIN, A. Pasado y presente de los manuales escolares. In: RUIZ, B. Julio (Ed). La cultura escolar de Europa: tendencias historicas emergentes. Madrid, Biblioteca Nueva, 2000, p. 107-165.

[8] CHOPPIN, Alain. História dos Livros e das edições didáticas: sobre o estudo da arte. Revista da Faculdade de Educação da USP. Educação \& Pesquisa. Set/dez 2004.

[9] DELIZOICOV, D.; ANGOTTI, J.A.; PERNAMBUCO, M.M. Ensino de Ciências: fundamentos e métodos. 3 ed. São Paulo: Cortez, 2009.

[10] FREITAG, B. Escola, Estado \& Sociedade. 6 ed. São Paulo: Moraes, 1980..

[11] HÖFLING, Eloísa de Mattos. A Trajetória do Programa Nacional do Livro Didático do Ministério da Educação no Brasil. In: FRACALANZA, Hilário; MEGID NETO, Jorge (Org.). O Livro Didático de Ciências no Brasil. Campinas: Komedi, 2006. P. 21-31.

[12] HORIKAWA, Y.; JARDILIN, J.L. A formação de professores e o livro didático: avaliação e controle dos saberes escolares. Revista Lusófona de Educação. Lisboa, n.15, 2010.

[13] JULIA, D. A cultura escolar como objeto histórico. Revista Brasileira de História da Educação, Editora Autores Associados: Campinas, n. 1, p. 9-44, 2001

[14] KRASILCHIK, M. O professor e o currículo das ciências. São Paulo: EPU: Editora da Universidade de São Paulo, 1987.

[15] LORENZ, K. M. Os livros didáticos e o ensino de ciências na escola secundário brasileira no século XIX. Ciência e Cultura, v.38, n.3, p. 426-435, 1986

[16] ROMANELLI, O. O. História da Educação no Brasil. 7 ed. Petrópolis, RJ; Vozes, 1985.

[17] SELLES, S.E.; FERREIRA, M.S. Influências histórico-culturais nas representações sobre as estações do ano em livros didáticos de ciências. Ciência e Educação, Bauru, v.10, n.1, p.101-110, 2004.

[18] SILLOS, A. E. ; SANTOS, W. L. P. dos. Percepções de alunos do ensino médio sobre o livro didático de Química. In: Encontro Nacional de Pesquisa em Educação em Ciências, IX, 2013, Águas de Lindóia-SP. Anais... 2013. p. 1-8. 


\section{Capítulo 14}

Percepção ambiental e relações de educação ambiental dos moradores residentes no entorno de lagoas na cidade de Zé Doca, Maranhão

\section{Edimar Campelo Araújo \\ Osiel César da Trindade Junior}

Resumo: A percepção ambiental pode refletir a qualidade do espaço ocupado, atribuindo questões de caráter e respeito ético a si e ao próximo. 0 objetivo foi analisar a percepção ambiental e as relações de educação ambiental com moradores residentes próximos de lagoas na cidade de Zé Doca, Maranhão. A metodologia levou em consideração a aplicação de questionários com a finalidade de obter dados a respeito da relação dos moradores com o espaço urbano, bem como com o meio ambiente das lagoas. Foram adotados os critérios de contagem de pontos, considerando os riscos socioambientais como de nível baixo, moderado e alto. Os resultados revelaram a percepção ambiental dos moradores com o nível de educação ambiental a respeito das boas práticas de conscientização dos manejos com o ambiente urbano.

É necessário o processo de Educação Ambiental de forma sistemática e transversal, assegurando uma abordagem interdisciplinar do ambiente social urbano.

Palavras-chave: Riscos ambientais. Áreas de lagoas. Educação Ambiental 


\section{INTRODUÇÃO}

A sociedade humana cresceu muito nos últimos anos por conta do aumento na perspectiva de vida e altos índices de natalidade levando as pessoas a buscar novas áreas para construir suas moradias. 0 meio ambiente sofre alta degradação provocada pelo desenvolvimento urbano desprovido de planejamento ambiental e manejo adequado dos recursos naturais. Com base nisso, se tem a preocupação em ter um desenvolvimento urbano que não cause tantos danos ao meio ambiente, questão que tem sido tema de debates em todo o mundo. A Educação Ambiental é um tema muito discutido atualmente devido ao fato de se perceber a necessidade de uma melhoria do mundo em que vivemos, pois é facilmente notado que estamos regredindo cada vez mais em nossa qualidade de vida de um modo geral, nos deixando levar por nossas obrigações diárias. Nosso tempo nos parece cada vez mais curto porque temos cada vez mais compromissos (GUEDES, 2006).

A educação ambiental é um processo permanente no qual os indivíduos e a comunidade tomam consciência do seu meio ambiente e adquirem conhecimentos, valores, habilidades, experiências e determinação que os tornem aptos a agir e resolver problemas ambientais, presentes e futuros (DIAS, 2004).

Os estudos de percepção ambiental são importantes uma vez que é por meio destes que adquirimos consciência do mundo, estando relacionado a aprendizagem e sensibilização envolvidas nos processos de educação ambiental. Os comportamentos humanos derivam de suas percepções do mundo, cada um reagindo de acordo com suas concepções e relação com meio, dependendo de suas relações anteriores, desenvolvida durante sua vida (MENGHINI, 2005).

Educação ambiental é um tema debatido frequentemente em todas as mídias, tais como TVs, rádio, internet, o problema é que a população em sua grande maioria não chega a pensar nas consequências que o meio ambiente sofre com o desenvolvimento sem planejamento ambiental.

De acordo com Macedo (2005), o nível de conscientização ambiental de cada indivíduo está diretamente relacionado ao grau de percepção ambiental do mesmo. Para Pádua (et. al., 2003) não basta saber, é indispensável à inclusão de valores sensibilizar as pessoas de forma a estimular a criatividade, oferecendo meios para que estas desenvolvam suas habilidades e capacidades de engajar-se em processos de mudança e de solucionar problemas.

o desequilíbrio entre as relações de sociedade humana com o ambiente em que está inserida se materializa como um dos grandes problemas da atualidade, que desafia constantemente a comunidade científica (FREITAS, 2009).

Pensando nisso, esse projeto foi elaborado com o objetivo de analisar a percepção ambiental das populações residentes no entorno de lagoas da cidade de Zé Doca no Maranhão, levando em conta o grau de risco ambiental no qual estão envolvidos. Ao final do estudo a população alvo será orientada sobre os riscos ambientais no qual estão sujeitos visando melhoria em sua qualidade de vida.

\section{RESULTADOS E DISCUSSÃO}

Foram distribuídos 50 questionários entre 20 famílias com um total de 50 pessoas, sendo 30 do gênero masculino e 20 do gênero feminino, tendo em média 2 a 3 membros na família os questionários devolvidos somaram um total de 48. Os questionários foram aplicados a moradores residentes no entorno da lagoa conhecida como prainha que podem estar correndo algum risco ambiental devido às enchentes da lagoa e acúmulo de lixo. Situada no bairro Santa Terezinha na cidade de Zé Doca - Maranhão a lagoa prainha é frequentada por muitas pessoas que a procuram para lazer. 0 questionário foi composto por 11 perguntas de múltipla escolha as quais foram respondidas pelos moradores, a Tabela 1 mostra os resultados das respostas da primeira questão respondida pelos moradores. 
Tabela 1. Perguntas relacionadas às características que fazem parte do meio ambiente.

\begin{tabular}{|c|c|c|}
\hline $\begin{array}{c}\text { Para você o que faz parte } \\
\text { do meio ambiente? }\end{array}$ & Respostas & $\%$ \\
\hline Árvores & 48 & 100 \\
\hline Pessoas & 24 & 50 \\
\hline Água & 27 & 56,25 \\
\hline Poluição & 3 & 6,25 \\
\hline Carros & 3 & 6,25 \\
\hline Lixo & 4 & 8,33 \\
\hline Esgoto & 4 & 8,33 \\
\hline Animais & 29 & 60,41 \\
\hline
\end{tabular}

Fonte: Autoria própria, 2016.

A primeira questão foi de múltipla escolha para os moradores decidirem o que faz parte do meio ambiente para eles, essa questão serviu como porta de entrada para medir a percepção ambiental dos moradores das áreas consideradas de risco na qual a maioria das respostas foram focadas nas árvores (100\%), água (56,25\%), animais $(60,41 \%)$.

Tabela 2. Perguntas sobre a percepção ambiental das lagoas no entorno das residências.

\begin{tabular}{|c|c|c|}
\hline $\begin{array}{c}\text { Como você julga a situação ambiental da lagoa que } \\
\text { fica no entorno da sua casa? (Apenas uma resposta). }\end{array}$ & Respostas & $\%$ \\
\hline Muito ruim & 14 & 29,16 \\
\hline Ruim & 10 & 20,83 \\
\hline Regular & 19 & 39,53 \\
\hline Boa & 5 & 10,41 \\
\hline Ótima & 0 & 0 \\
\hline Total & 48 & $\approx 100$ \\
\hline
\end{tabular}

Fonte: Autoria própria, 2016.

As respostas foram tabuladas e os resultados apontaram a situação ambiental da lagoa segundo os moradores tendo uma situação considerada regular (39,53\%), mesmo a lagoa que é conhecida como prainha contendo segundo análises, a presença de coliformes fecais em sua água podendo causar doenças à população que for exposta aquela água.

Coliformes fecais ou coliformes termo tolerantes são bactérias capazes de desenvolver e/ou fermentar a lactose com produção de gás a $44^{\circ} \mathrm{C}$ em 24 horas. A principal espécie dentro desse grupo é a Escherichia coli. Essa avaliação microbiológica da água tem um papel destacado, em visto da grande variedade de microrganismos patogênicos, em sua maioria de origem fecal, que pode estar presente na água (BETTEGA, 2006).

Tabela 3. Perguntas sobre a questão ambiental do bairro onde os moradores residem.

\begin{tabular}{|l|c|c|}
\hline \multicolumn{1}{|c|}{$\begin{array}{c}\text { Em relação ao meio ambiente do seu bairro, como você } \\
\text { julga a situação ambiental dele? (Apenas uma resposta). }\end{array}$} & \multicolumn{1}{c|}{ Respostas } & $\%$ \\
\hline Muito ruim & 19 & 39,58 \\
\hline Ruim & 17 & 35,41 \\
\hline Regular & 10 & 20,83 \\
\hline Bom & 2 & 4,16 \\
\hline Ótimo & 0 & 0 \\
\hline Total & 48 & $\approx 100$ \\
\hline
\end{tabular}

Fonte: Autoria própria, 2016.

A maioria dos moradores respondeu que a situação ambiental do seu bairro é muito ruim (39,58\%) que, segundo eles, tem muito lixo acumulado próximo às suas casas. A disposição dos resíduos sólidos em áreas impróprias e sem os devidos estudos do local provoca sérios problemas ambientais, sociais e de saúde pública (Silva, 2010). 
A deposição dos resíduos em áreas impróprias como em terrenos baldios é um problema cada vez mais evidente, e o gerenciamento por parte dos órgãos públicos nem sempre é uma tarefa fácil tendo em vista que no Brasil a exemplo de outros países a maioria destes resíduos não é aproveitada da maneira devida, no entanto vale salientar que a própria situação econômica tem propiciado o desenvolvimento de segmentos como o de sucatas, recicladoras, catadores e cooperativas de coleta de resíduos sólidos.

Tabela 4. Perguntas sobre os principais danos que mais agridem o meio ambiente no entorno das lagoas da cidade de Zé Doca, Maranhão.

\begin{tabular}{|l|c|c|}
\begin{tabular}{|l} 
Qual dos eventos abaixo causa mais danos ao Meio Ambiente? \\
(Apenas uma resposta).
\end{tabular} & Respostas & $\%$ \\
\hline Consumo desordenado de produtos descartáveis. & 22 & 45,83 \\
\hline Poluição do solo, água e ar. & 23 & 47,91 \\
\hline Superlotação populacional. & 2 & 4,16 \\
\hline Tráfego de automóveis & 1 & 2,08 \\
\hline Passear a pé & 0 & 0 \\
\hline Total & 48 & $\approx 100$ \\
\hline
\end{tabular}

Fonte: Autoria própria, 2016.

Os moradores demonstram um claro entendimento sobre eventos que causam danos ao meio ambiente, as respostas mais votadas foram a Poluição do solo, água e ar $(47,91 \%)$ e o Consumo desordenado de produtos descartáveis $(45,83 \%)$. A produção exagerada de lixo é uma das principais responsáveis pela poluição do solo. Durante o processo de decomposição de restos de alimentos, ocorre a produção de gases e de chorume, que é um líquido extremamente poluente e com forte odor. 0 chorume infiltra o solo, causando a sua contaminação, além de atingir o lençol freático (água subterrânea).

Para Santos (2015), os poluentes do solo podem ser diversos, assim como seus efeitos. Dependendo da substância que entra em contato com o solo, podem ser desencadeados problemas como a inviabilização da sobrevivência de plantas e animais, alterações do ciclo do nitrogênio e desenvolvimento de doenças na população.

\section{CONCLUSÃO}

A concepção de percepção ambiental reflete as impressões, efeitos, sentidos e o modo como os indivíduos percebem e são afetados pelo entorno. Os moradores possuem conhecimento de meio ambiente e conscientização ambiental para preservar o meio ambiente local.

A influência antrópica, nesse caso o lixo, segundo os moradores é um ponto negativo da lagoa, pois a coleta de lixo é feita apenas uma vez na semana, onde às vezes segundo os moradores, a coleta acontece em intervalos ainda maiores. Algumas das pessoas que moram no entorno da lagoa afirmam que a defendem contra a atitude de alguns moradores e veranistas, isso mostra a preocupação e a importância que os moradores dão ao estado da lagoa e do meio ambiente, sabendo que isso pode evitar problemas futuro.

Dadas as constantes alterações percebidas na lagoa e entorno pelos moradores, um trabalho de educação ambiental com base na sensibilização e futura conscientização é de suma importância.

\section{REFERÊNCIAS}

[1] BETTEGA, Janine Maria Pereira Ramos et al. Métodos analíticos no controle microbiológico de água para consumo humano. Cienc. Agrotec. 2006, vol.30, n.5, pp. 950-954. ISSN 1413-7054.

[2] DIAS, Genebaldo Freire. Educação ambiental: princípios e práticas. 9a ed., São Paulo: Gaia, 2004.

[3] FREITAS, Mirlaine Rotoly de. Conservação e percepção ambiental por meio da triangulação de métodos de pesquisa. Dissertação (Mestrado) - Universidade Federal de Lavras, 2009.

[4] GUEDES, José Carlos de Souza. Educação ambiental nas escolas de ensino fundamental: estudo de caso. Garanhuns: Ed. do autor, 2006.

[5] MACEDO, Renato Luiz Grisi. Percepção, conscientização e conservação ambientais. Lavra: UFLA/FAEPE, 2005. 
[6] MENGHINI, Fernanda Barbosa. As trilhas interpretativas como recurso pedagógico. Dissertação (Mestrado) Universidade do Vale do Itajaí, 2005.

[7] PÁDUA, S.M.; TABANEZ, M.F.; SOUZA, M.G. A abordagem participativa na educação para a conservação da natureza. In: CULLEN, JR., L. RUDRAN, R.; VALLADARES-PÁDUA, C. (Org.). Métodos de estudos em biologia da conservação e manejo da vida silvestre. Curitiba: Universidade Federal do Paraná; Fundação O Boticário de Proteção à Natureza, 2003. p. 557-591.

[8] SILVA, Mônica Maria Pereira et all. Avaliação Sanitária de Resíduos Sólidos Orgânicos Domiciliares em Municípios do Semiárido Paraibano. Revista Caatinga, Mossoró, v. 23, n. 2, p. 87-92, abr.- jun., 2010.

[9] SANTOS, Vanessa dos. Poluição do Solo. Biologia net, $2015 . \quad$ Disponível em:http://biologianet.uol.com.br/ecologia/poluicao-solo.htm. Acesso em: junho de 2016. 


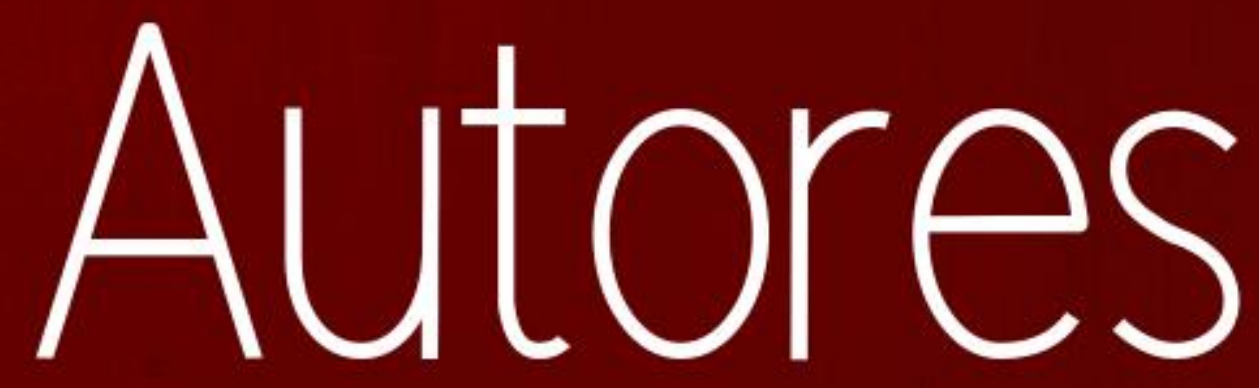




\section{BRUNA GUZMAN DE JESUS (ORGANIZADORA)}

Graduada em Pedagogia: docência e gestão pela PUC Minas (2009), pós-graduada em Orientação, Supervisão e Gestão Escolar (2020) assim como em Metodologia do Ensino de Língua Portuguesa e Língua Estrangeira (2014) pelo Grupo Educacional UNINTER/ FACINTER - Faculdade Internacional de Curitiba. Pós-graduanda em Neuropsicopedagogia pela Faculdade Metropolitana MG. É Coordenadora Pedagógica.

\section{CAMILA FERNANDA BASSETTO}

Possui graduação em Matemática pela Universidade Estadual Paulista "Júlio de Mesquita Filho" UNESP IBILCE (2004), mestrado em Estatística pela Universidade Federal de São Carlos - UFSCar (2007) e doutorado em Ciências - Engenharia de Produção pela Escola de Engenharia de São Carlos - Universidade de São Paulo - EESC/USP (2010). Atualmente é professora assistente doutora da Faculdade de Ciências e Letras de Araraquara - Universidade Estadual Paulista "Júlio de Mesquita Filho" - FCLAr/UNESP. Docente do departamento de Educação, atua em pesquisas na área de Modelos Hierárquicos e Métodos Quantitativos Aplicados à Educação.

\section{CRISTIANE DUQUE DE SOUZA PANTOJA}

Pós-Graduada em Metodologia da Educação Superior pela Universidade do Estado do Amazonas UEA e em Psicopedagogia com Ênfase em Educação Especial pela Faculdade Wenceslau Braz FACIBRA . Pedagoga na Rede Estadual de Ensino do Amazonas há 10 anos.

\section{DULCINÉIA DA SILVA ADORNI}

Professora Assistente da Universidade Estadual do Sudoeste da Bahia (UESB), campus Itapetinga. Doutoranda no Programa de Pós-Graduação em Educação e Contemporaneidade PPGEDUC/DINTER, da Universidade do Estado da Bahia (UNEB). Graduada em Pedagogia pela Faculdade de Ciências e Letras da Universidade Estadual Paulista Júlio de Mesquita Filho (UNESP), campus Araraquara-SP. Mestre em Educação também pela UNESP/ Araraquara. Especialista em Problemas de Aprendizagem e em Psicopedagogia pela Faculdade de Medicina da Universidade de São Paulo (USP), campus Ribeirão Preto-SP. Experiência na área de Educação, com ênfase em Psicologia da Educação e Estágio Supervisionado em Licenciatura em Química e Física. Desenvolve e orienta pesquisas nas áreas de Formação Docente em Química e Violência Escolar (bullying). Pesquisadora dos grupos GPEP/UESB e DIVERSO/UNEB.

\section{EDIMAR CAMPELO ARAÚJO}

Possui graduação em Licenciatura em Educação Física pela Universidade Estadual do Piauí (1996), graduação em Licenciatura em historia pela Universidade Federal do Piauí (2004), graduação em Pedagogia pelo Instituto Superior de Educação Programus (2014) e mestrado em Ciências da educação pela Universidade Lusófona de Humanidades e Tecnologias (2014). Doutorando em Ciências da Educação em andamento pela UNR - AR. Atualmente é clt da Faculdade Evangélica do Piauí, professor horista do Instituto Superior de Educação Programus, coordenador do Instituto Superior de Educação Programus e celetista da Faculdade Regional da Bahia - UNIRB. , atuando principalmente nos seguintes temas: educação infantil, ludicidade, áreas de risco, educação ambiental e educação.

\section{EDNA LUIZA DE SOUZA}

Doutora e Mestre em Educação pela Universidade Federal do Paraná - UFPR. Docente da Rede Estadual de Educação Básica do Estado do Paraná. Temas de interesse em pesquisas: Livros didáticos, Ensino de Ciências, Políticas Públicas de educação. 


\section{ELAINE CHRISTINA MONTEIRO DE OLIVEIRA}

Psicóloga especialista em Terapia Cognitiva Comportamental, formada em Análise do Comportamento Aplicada, especializanda em Análise do Comportamento Aplicada. Atua como psicóloga clínica e acompanhante terapêutica.

\section{FERNANDA GISELLE MORAIS DO VALE CESTARI}

Graduada em Letras Inglês pela Fundação de Ensino Superior de Olinda e em Pedagogia pela UNOPAR. Pós-graduada pela UESC em Estudos Comparados em Literaturas de Língua Portuguesa, pela Universidade Católica de Recife em Psicopedagogia Clínica e Institucional e em Libras pela Faculdade Eficaz . Mestre em Educação da UFPE. Desenvolve pesquisa sobre a aproximação entre abordagens pedagógicas e literárias para a formação e a educação e sobre bullying/violência escolar. Trabalhou como professora substituta da UESB- Universidade Estadual do Sudoeste da Bahia, trabalhou no curso de Pedagogia EAD da UESB. Atualmente é coordenadora pedagógica do Ensino Fundamental I do colégio Madre Savina Petrilli.

\section{GISELA DO CARMO LOURENCETTI}

Possui graduação em Pedagogia pela Universidade Estadual Paulista, Mestrado em Educação pela Universidade Federal de São Carlos e Doutorado em Educação Escolar pela Universidade Estadual Paulista Júlio de Mesquita Filho. Tem experiência na área de Educação, pesquisando principalmente os seguintes temas: escola pública, ensino fundamental, políticas educacionais, trabalho docente, cotidiano escolar, dilemas profissionais docentes e formação de professores. Atualmente, é Supervisora na Secretaria Municipal de Educação de Araraquara-SP.

\section{HILANA MARIA BRAGA FERNANDES ABREU}

Possui Formação em Psicologia pelo Centro Universitário de João Pessoa (UNIPÊ) (2003), graduação em Licenciatura em Psicologia Pelo Centro Universitário de João Pessoa (UNIPÊ) (2002), Especialização em Programa da Saúde da Família pela Faculdade de Ciências Sociais Aplicada (FACISA) (2005), Especialização em Docência do Ensino Superior pela Faculdade Santa Maria de Cajazeiras (2017) e mestrado em Psicologia (Psicologia Social) pela Universidade Federal da Paraíba (2007). Atualmente é professora da Faculdade Santa Maria de Cajazeiras-Pb, psicóloga efetiva da Prefeitura Municipal de Cajazeiras-PB e psicóloga efetiva da Fundação de Desenvolvimento da Criança e do Adolescente "Alice de Almeida". Tem experiência na área de Psicologia, com ênfase em Psicologia do Desenvolvimento Humano, atuando principalmente nos seguintes temas: criança, adolescente, interação mãe-criança, violência, medida socioeducativa, saúde mental.

\section{JÔNIA CYBELE SANTOS LIMA}

Possui graduação em Odontologia pela Universidade Federal do Rio Grande do Norte (1997),Doutorado em Saúde Coletiva pela Universidade Federal do Rio Grande do Norte(2019), Mestrado em Odontologia Social na área de concentração em Saúde Coletiva pela Universidade Federal do Rio Grande do Norte (2011), Especialização em Odontologia e Saúde coletiva pela Universidade Federal do Rio Grande do Norte( 2003) e Aperfeiçoamento em Odontopediatria pela ABO secção-RN em(2000). Atualmente é docente do Departamento de Saúde Coletiva(DSC) da Universidade Federal do rio Grande do norte(UFRN),como professora Temporária desde 2013.Tem experiência na área de Odontologia, com ênfase em Odontologia e na Saúde Coletiva, atuando principalmente nos seguintes temas: Saúde Coletiva,Promoção à saúde, Atenção Primária,Gestão Participativa,Tutoria nos Estágios do Curso de Saúde Coletiva e nas Disciplinas Saúde e Cidadania I e II da UFRN,Gestão de Recursos Humanos,Saúde Pública,Políticas de Saúde do Brasil e do RN,Saúde da Mulher,Educação em saúde, Formação Profissional em Saúde, Gestão do Trabalho e Educação na Saúde, Formação Multidisciplinar e Prevenção da Doença Cárie.Atuou como Dentista da Prefeitura Municipal de Jundiá/RN na Estratégia de Saúde da Família dos anos de 2002 à 2012 e na coordenação de Saúde Bucal e na assistência de 2012 à 2015.Esteve membro do conselho municipal de saúde do município de Jundiá/RN, por duas gestões, como representante 
dos profissionais de saúde.Tendo sido selecionada como delegada para representar os profissionais de saúde nas Conferências Estaduais de saúde do Rio Grande do Norte de 2007 e 2011.Tendo sido capacitada como conselheira no ano de 2007.Atuou como conselheira Estadual de Saúde representando o Conselho de Odontologia Secção RN,como membro suplente de 2016 á 2018.

\section{JOSÉ AURIMAR DOS SANTOS ANGELIM}

Doutor em Educação Matemática pelo Programa de Pós-Graduação em Educação em Ciências e Matemáticas do Instituto de Educação Matemática e Científica - IEMCI da Universidade Federal do Pará - UFPA. É Mestre em Educação Matemática pela Universidade Federal do Pará. Possui graduação em Licenciatura em ciências exatas com habilitação em Matemática pela Universidade do Estado da Bahia (1998). Atualmente é professor do Instituto Federal de Educação, Ciência e Tecnologia Baiano, Campus de Senhor do Bonfim. Tem experiência na área de Matemática da Educação Básica e Superior, Graduação e Pós-Graduação, e Educação Profissional, com ênfase em Educação Matemática, na área de formação de professores, processos de ensino e de aprendizagem de matemática, pesquisa em educação. É membro do projeto de cooperação internacional entre Brasil e Portugal, constituindo a equipe do projeto AERA, financiado pela CAPES. Atualmente é coordenador do Colegiado de Licenciatura em Ciências da Computação do IF Baiano.

\section{JOSÉ CAMILO RAMOS DE SOUZA}

Possui graduação em Licenciatura Plena em Geografia pela Universidade Federal do Amazonas (1995), Bacharelado em Geografia pela Universidade Federal do Amazonas (1998), Especialização em Gestão em Etnodesenvolvimento pela Universidade Federal do Amazonas (2002 - 2003), Mestrado em Educação pela Universidade Federal do Amazonas - FACED (2004 - 2006) e doutorado em Ciências obtido no Programa de Geografia (Geografia Física) - Área de Concentração: Geografia Física, pela Universidade de São Paulo-USP, em 04/07/2013. Professor da Universidade do Estado do Amazonas. Tem experiência na área de Geografia e Educação. Geografia: Geografia Econômica, Geografia Agrária, Metodologia do Ensino em Geografia, Prática do Ensino em Geografia, Geografia do Turismo, Cartografia aplicada ao ensino de Geografia etc. Educação: Estágio Supervisionado, Currículo, Metodologia da Pesquisa e Estudos. Estudo sobre imigrantes japoneses na Amazônia, ribeirinhos da Amazônia e pensamento geográfico da Amazônia. Estudo sobre Gestão das águas e Governança e regulação de recursos hídricos.

\section{JÚLIO PEREIRA DA SILVA}

Doutorando pelo Programa de Pós-Graduação em Educação Matemática e Tecnológica da Universidade Federal de Pernambuco - EDUMATEC/UFPE. Mestre em Ensino de Ciências e Educação Matemática pelo Programa de Pós-Graduação em Ensino de Ciências e Educação Matemática da Universidade Estadual da Paraíba - PPGECEM/UEPB. Especialista em Supervisão e Orientação Educacional pelas Faculdades Integradas de Patos - FIP (2015). Possui Licenciatura Plena em Pedagogia pela Universidade Federal de Campina Grande - UFCG - Campus I (2013). Pesquisador nos Grupos de Pesquisa Leitura e Escrita em educação Matemática - LEEMAT, da Universidade Estadual da Paraíba/CNPq. Tem experiências em salas de aulas da Educação Básica e Ensino Superior.

\section{LUCIANO GONÇALVES TEODORO}

Licenciado em Pedagogia pela Faculdade de Ciências e Letras, Câmpus Araraquara, da Universidade Estadual Paulista; é mestre em Educação Escolar pelo Centro Universitário Moura Lacerda, de Ribeirão Preto-SP. Professor de Educação Básica-I, da Prefeitura Municipal de Ribeirão Preto, atualmente ocupa o cargo de diretor de um CEI - Centro de Educação Infantil.

\section{MANOEL MESSIAS GOMES}

Graduado em Ciências com habilitação em matemática, pela Universidade do Estado do Rio Grande do Norte - UERN. Graduado também em Ciências Biológicas, pela Universidade Federal do Rio 
Grande do Norte. Mestre e Doutor em Ciências da Educação Pela Faculdade ISEL de Brasília (Mestrado) e pela EMIL BRUNER WORLD UNIVERSITY(Doutorado). Professor da Rede Estadual de Ensino do Rio Grande do Norte, atuando como Professor do Ensino Médio, na Escola estadual Governador Walfredo Gurgel, na Cidade de Antônio Martins - RN. Pesquisador, com experiência na área de Formação de Professores para a Educação de Jovens e adultos.

\section{MARCOS JOSÉ CUSTÓDIO CUSTÓDIO}

Possui Licenciatura em Ciências com habilitação em Matemática pela Universidade do Estado da Bahia (2000), curso de especialização em Gestão Educacional (2004), especialização em Metodologia do Ensino da Matemática (2007), ambos pela Universidade do Estado da Bahia. Mestrado em Ciências pela Universidade Federal Rural do Rio de Janeiro (2011) e Doutorado em Educação (em andamento) pela Universidad Nacional de Rosario - Arg. (2017-2021). Atuou como professor de Matemática na rede oficial do Estado da Bahia de 2000 a 2008. Atualmente é professor de Matemática do Instituto Federal de Educação, Ciência e Tecnologia Baiano Campus de Senhor do Bonfim. Tem experiência na área de ensino de Matemática, atuando principalmente na Formação de Professores e nos processos de ensino e aprendizagem de Matemática.

\section{MARIA ANAILSA DOS SANTOS FURTADO DIAS}

Formação em Letras, Pedagogia e Psicologia. Especialista em Língua, Linguística e Literatura e em Práticas Assertivas em Didática e Gestão da Educação Profissional Integrada à Educação de Jovens e Adultos - EJA/PROEJA. Atua como Professora das séries iniciais e finais do ensino fundamental em instituições municipais.

\section{MARIA SELTA PEREIRA}

Professora da Rede Municipal de Fortaleza - Atualmente Apoio Pedagógico a Biblioteca - E.M. Narciso Pessoa de Araújo. Graduada em Pedagogia e com Habilitação em Português e Inglês pela Universidade Estadual Vale do Acaraú (2001 a- 2003).Pós-Graduada em Ciências da Religião; Psicopedagogia Institucional e Clinica; AEE-Atendimento Educacional Especializado. Alfabetização e MultiletramentoS -UECE

\section{MATEUS DE SOUZA COELHO FILHO}

Graduado em Pedagogia-Universidade Federal do Amazonas, Pós-Graduado em Metodologia da Educação Superior-Universidade do Estado do Amazonas, Mestre em Educação e Ensino de Ciências na Amazônia-Universidade do Estado do Amazonas, Doutor em Educação em Ciências e Matemática pelo Programa de Pós-Graduação em Educação em Ciências e Matemática - Rede Amazônica de Educação em Ciências e Matemática-REAMEC. É professor da Universidade do Estado do Amazonas. Pesquisador do Grupo de Estudos e Pesquisas em Educação Matemática. Possui experiência na área de Formação de Professores. Educação de Jovens e Adultos, Planejamento de Ensino e Avaliação, Didática Geral, Estrutura e Funcionamento do Ensino Básico.

\section{NILSON MARCOS DIAS GARCIA}

Doutor em Educação e Mestre em Ensino de Física, pela Universidade de São Paulo. Docente e pesquisador do Programa de Pós-Graduação e Tecnologia e Sociedade - PPGTE da Universidade Tecnológica Federal do Paraná - UTFPR e do Programa de Pós-Graduação em Educação - PPGE da Universidade Federal do Paraná. Integrante e líder do Grupo de Estudos e Pesquisas em Ensino de Física - GEPEF-UTFPR e integrante do Núcleo de Pesquisas e Publicações Didáticas - NPPD-UFPR. Temas de interesse em pesquisas: Livros didáticos de Física e de Ciências, Ensino de Física, Educação Profissional e Políticas públicas de educação. 


\section{NOELIA KALLY MARINHO DE SOUSA}

Bacharela em Psicologia pela Faculdade Santa Maria - FSM, Cajazeiras - PB (2017). Mestrado em Saúde Coletiva pelo Programa de Pós-graduação em Saúde Coletiva (PPGSC) da Universidade Federal do Paraná (UFPR) (2020). Pós-graduada em Psicologia Social pela Faculdade Unyleya (2020). Pós-graduada em Psicologia Cognitivo Comportamental pela Faculdade Unyleya. Atua como Psicóloga clínica e pesquisadora.

\section{OSIEL CÉSAR DA TRINDADE JUNIOR}

Atualmente é doutorando em Educação pela Universidade Nacional de Rosário, na Argentina; Mestre em Desenvolvimento e Meio Ambiente (UFPI/PRODEMA); Especialista em Docência do Ensino Superior (Universidade Cândido Mendes); Licenciado em Ciências Biológicas (UESPI). Professor EBTT do Instituto Federal de Educação, Ciência e Tecnologia do Maranhão (IFMA Campus - Codó). Tem experiência na área de Educação Básica e Superior, com ênfase em Educação Ambiental, Meio Ambiente, Biologia Geral, Microbiologia Geral e de Fungos Zoospóricos .

\section{PATRÍCIA EMILLE BENTO GONÇALVES}

Pós-graduanda em Psicologia clínica e Hospitalar, capacitação em tanatologia, luto, mudanças e perdas. Atua como Psicóloga clínica.

\section{RAFAEL FERREIRA FERNANDES}

Graduado e licenciado em Física pela Universidade Estadual da Paraíba -UEPB, (2018); cursa uma pós-graduação em Ensino de Física e Matemática, e uma segunda licenciatura em Matemática pela FAVENI; atualmente atua como professor da disciplina de física na ECIT Sebastião Guedes da Silva localizado na cidade de Teixeira-PB; Participou do Programa Brasil Alfabetizado (P.B.A) como professor-educador, atuou como tutor em reforço particular nível médio das disciplinas de física e matemática para estudantes do SESI - Patos (2017); possui experiência como professor da educação básica e técnica na área de exatas; Participou tanto como estudante como professor de vários projetos, programas, oficinas e palestras, pela UEPB e fora dela.

\section{ROBERTO ROQUE ANTUNES OLIVEIRA}

Bacharelado em Administração pela Universidade Católica de Brasília (1994); graduando em física pela Universidade Paulista; é servidor Público Federal aposentado; tem cursos na área de administração financeira, língua portuguesa; oratória, possui experiência com seminários de auditorias públicas e com licitações do governo.

\section{ROMILSON ALVES DA SILVA}

Licenciado em Pedagogia pela Universidade Estadual Vale do Acaraú (UVA), 2003 a 2005; pósgraduado em Pedagogia Escolar: Supervisão, Orientação e Administração, FACINTER/IBPEX, 2005 a 2006; graduado em licenciatura plena em Geografia pela FAEL, 2016 a 2019; pós-graduando a nível de especialização em Geografia, Meio Ambiente e Sustentabilidade e Psicopedagogia Institucional e Clínica, pela Faculdade Venda Nova do Imigrante (FAVENI).

\section{RONARA VIANA CORDOVIL}

Pedagoga concursada pela SEDUC (2018), Mestra pelo Programa de Pós-Graduação em Educação e Ensino de Ciências na Amazônia - PPGECA (2016 à 2018). Possui graduação em Pedagogia pelo Centro de Estudos Superiores de Parintins (2014). Durante a graduação foi voluntaria de iniciação científica da Universidade do Estado do Amazonas (PAIC), Programa de Monitoria da Universidade do Estado do Amazonas (UEA/2012) e Bolsista do Programa Institucional de Bolsas de Iniciação à Docência (PIBID/2014). Atuou como professora de Reforço Escolar programa desenvolvido pela Secretaria de Estado de Educação e Qualidade do Ensino / SEDUC (2012 à 2014). Foi professora SESC ler - Serviço Social do Comercio / Parintins/AM (2015 á 2016). Foi Professora Assistente pelo 
curso de pós-graduação em Letramento Digital, ofertado pela Universidade do Estado do Amazonas (UEA/2018 á 2020) em parceria com a Secretaria de Estado de Educação e Qualidade do Ensino (SEDUC), Professora Substituta pela Universidade Federal do Amazonas (UFAM/2019) e Professora Formadora do PARFOR (2019 e 2020). Pode-se dizer que tem experiência na área de Educação, formação de professores com ênfase em nos seguintes temas: Metodologias de Ensino aprendizagem em Ensino de Ciências, Ensino de geografia, Ensino de História. Língua Portuguesa. Ludicidade. Educação psicomotora. Alfabetização. Qualidade de vida. Professores. Pedagogos. Prática pedagógica. Educação do Campo

\section{RUTH NAYARA FIRMINO SOARES}

Possui graduação em Pedagogia pela Universidade Federal do Rio Grande do Norte (2010); Possui Pós graduação em Pedagogia do Movimento na Infância pela Universidade Federal do Rio Grande do Norte (2011); Experiência na área de Educação, com ênfase em coordenação. Discente do último período do curso de Nutrição pela Universidade Potiguar (UNP) -Rio Grande do Norte (2020). Pós graduanda em Nutrição das Doenças Crônicas Não Transmissíveis pela Faculdade Venda Nova do Imigrante (FAVENI), (2020). Discente do terceiro período do curso de Saúde Coletiva - Bacharelado - pela Universidade Federal do Rio Grande do Norte.

\section{SEBASTIÃO DE SOUZA LEMES}

É professor pesquisador da UNESP - Universidade Estadual Paulista Júlio de Mesquita Filho e atua nas áreas de Avaliação Educacional, Currículo, Tecnologia Educacional e Política Pública. Possui graduação em Química com Licenciatura em Ciências, Mestrado em Educação pela Universidade Federal de São Carlos, Doutorado em Psicologia pelo Instituto de Psicologia da USP em São Paulo e Pós Doutorado pelo Instituto de Educação da Universidade de Lisboa. Professor no Programa de Pós-Graduação em Educação Escolar na FCLAr/UNESP, onde atua e desenvolve pesquisa nas áreas de Avaliação, Currículo, Tecnologia e Politica Pública.

\section{VIRGILIO BANDEIRA DO NASCIMENTO FILHO}

Possui Mestrado em Teologia com a Linha de Pesquisa Educação Comunitária com Infância e Juventude pela Faculdade EST (2014). Doutorando no Programa de Pós-graduação em Educação em Ciências e Matemática (REAMEC), Pós-Graduação em Didática do Ensino Superior pela Faculdade Tháhiri/Iseama - AM (2009), Pós Graduação em Gestão Estratégica e Qualidade pela Ucam - Universidade Cândido Mendes ? RJ (2004). Graduado em Pedagogia pela UFPA (Universidade do Estado do Pará (1999). Professor Concursado da Universidade do Estado do Amazonas ministrando as disciplinas Estágio, Didática, Pesquisa e prática Pedagógica, Currículo Educacional, Sociologia da Educação, Legislação da Educação Básica. Desenvolve pesquisa sobre Formação de Professores e Didática. Faz parte do grupo de Pesquisa EDUCIENCIA, Laboratório de Ensino de Ciências - EDUCIENCIA, do(a) Universidade Federal de Rondônia 
